- 数据论文・

\title{
青藏高原与横断山被子植物区系演化的 细胞地理学特征
}

\author{
王家坚 ${ }^{1}$ 彭智邦 ${ }^{1}$ 孙 航 $^{2}$ 聂泽龙 ${ }^{1}$ 孟 盈 ${ }^{*}$ \\ 1 (吉首大学生物资源与环境科学学院植物资源保护与利用重点实验室, 湖南吉首 416000) \\ 2 (中国科学院昆明植物研究所东亚植物多样性与生物地理学重点实验室, 昆明 650201)
}

\begin{abstract}
摘要: 青藏高原与横断山集特殊的地理位置和复杂的地形地势以及高度丰富的植物区系成分于一体, 成为世界上 研究生物多样性起源与演化的热点地区之一。我们对这一地区被子植物的染色体数据进行了全面的统计分析, 结 果表明新多倍体在该地区只约占 $23 \%$ 的比例, 远低于其他高山地区, 这可能是由于这一地区特殊的地质历史或者 复杂的地形和生境等因素所导致的。低基数的二倍体占近一半的比例(43.3\%), 说明了二倍体水平上的染色体结构 和核型进化也是本地区物种分化的另一重要机制。古多倍体, 即高基数二倍体, 也占有较大的成分(33.7\%)。本地 区物种在细胞学遗传演化途径上的多样性与这一地区极高的物种多样性和特有性可能存在一定的联系。通过对青 藏高原及横断山地区被子植物区系进化中染色体演化机制的研究, 为探讨东亚以及北半球其他植物区系物种进 化、高山植物区系起源和演化等许多重大问题提供了有益的帮助。
\end{abstract}

关键词: 青藏高原; 细胞地理; 染色体进化; 多倍体; 被子植物

\section{Cytogeographic patterns of angiosperms flora of the Qinghai-Tibet Pla- teau and Hengduan Mountains}

Jia-Jian Wang ${ }^{1}$, Zhi-Bang Peng ${ }^{1}$, Hang Sun ${ }^{2}$, Ze-Long Nie ${ }^{1}$, Ying Meng ${ }^{1 *}$

1 Key Laboratory of Plant Resources Conservation and Utilization, College of Biology and Environmental Sciences, Jishou University, Jishou, Hunan 416000

2 Key Laboratory for Plant Diversity and Biogeography of East Asia, Kunming Institute of Botany, Chinese Academy of Sciences, Kunming 650201

\begin{abstract}
The Qinghai-Tibet Plateau and Hengduan Mountains is an important hotspot to study the origin and evolution of plant biodiversity, which is characterized by high species richness and endemism, as well as a unique location and complicated topography. Based on a comprehensive survey of the chromosome numbers of angiosperms from the Qinghai-Tibet Plateau and Hengduan Mountains, our results indicated that the frequency of neopolyploids (23\%) was much lower than expected. This was likely caused by the unique history, geology, and complicated topography and habitat. Another mechanism of chromosomal evolution is on the diploidy level (ca. 43.3\%), with variations of chromosomal restructure and karyotype. The number of paleopolyploids (diploids with high base numbers) was large in plants from this mountain area (33.7\%). The diversity of chromosomal evolution patterns of angiosperms from this region may be correlated to the high level of species richness and endemism. This study provides useful insight into our understanding of speciation, the origins of alpine flora and other important issues in eastern Asia and other regions in the Northern Hemisphere.
\end{abstract}

Key words: Qinghai-Tibet Plateau; cytogeography; chromosomal evolution; polyploidy; angiosperm

青藏高原和横断山是世界高山植物区系最为 丰富的区域之一，其维管植物种数占中国的一半以

* 通讯作者 Author for correspondence. E-mail: mengyingnie@163.com 
上(吴征镒，1988; 武素功等, 1995; 孙航，2002), 其 中仅限于该区域分布的特有种类在 $35 \%$ 以上(吴征 镒, 1988; 李锡文和李捷, 1993)。青藏高原尤其是其 东部高山峡谷和南部的喜马拉雅地区是世界上 25 个生物多样性热点地区之一(Myers et al, 2000)。青 藏高原和横断山区还是世界上特殊环境类型最多 及物种最丰富多样的区域之一(Ohba, 1988; 吴征 镒, 1988)。

植物染色体多倍化与物种进化的关系一直备 受关注, 多倍化是物种形成的一条重要途径, 特别 是在被子植物中最为普遍 (Stebbins, 1938，1971; Levin, 1983; 洪德元, 1990; Masterson, 1994)。通常 认为约有 $50-100 \%$ 的高等植物存在多倍化起源 (Soltis et al, 2009), 现存被子植物中约 20-40\%的种 类是最近形成的多倍体(Stebbins, 1971)。多倍体在 形态、生理和生活史等方面通常与它的祖先有明显 的区别, 这些特征可能是多倍体适应新的生态环境 的主要原因(Justin \& Douglas, 2002; Soltis et al, 2004)。植物染色体加倍而产生的“预适应机制”对植 物适应高海拔或高纬度极端环境有重要意义, 可能 是植物适应复杂多变的生境特别是极端环境的主 要机制(Otto, 2007), 所以, 多倍体又常见于具有恶 劣环境的高山和极地地区。在 $80^{\circ} \mathrm{N}$ 的北极圈附近多 倍体的植物种类可占到 $80 \%$ 以上(Brochmann et al, 2004)。

$\mathrm{Nie}$ 等(2005)对横断山区被子植物染色体数据 的统计中发现多倍体发生率仅为 $22 \%$, 低于被子植 物多倍体 30-35\%的平均水平, 这与该地区的植物 区系特点极不吻合。横断山区植物区系是一个年轻 的高山植物区系, 具有高度的物种多样性与特有 性, 多倍体应该占有比较高的比例。然而横断山区 只能代表青藏高原东南缘的区域, 为了全面了解我 国西南高山地区植物的染色体演化情况, 还需要对 整个青藏高原的植物染色体多倍体进化以及植物 区系在细胞学方面的演化特征与机制进行全面和 细致地分析和研究。

\section{1 数据收集与染色体倍性统计分析}

收集整理青藏高原和横断山区已报道的被子 植物染色体资料并进行倍性统计, 染色体数据收录 情况见附录 1 。同时结合植物的分布型、生活型与 生境海拔资料进行分析。属的分布型是植物区系分
析的一个重要内容, 吴征镒(1991)全面整理分析了 当时已有记载的中国种子植物属的分布区, 将其分 布区概括为 15 个类型和 30 多个变型，本文据此对青 藏高原的类群进行统计分析。植物生活型分为草本 和木本植物, 主要参考《中国植物志》和Flora of China。海拔数据主要根据文献记录的数据进行统 计，原始记载的海拔信息若为区间，取其中间值为 代表。

染色体倍性的确定主要依据Stebbins (1950)、 Goldblatt (1980)与Lewis (1980)的方法。Stebbins (1950)根据配子染色体数与属内染色体基数的倍数 情况把植物分为二倍体与多倍体, 二倍体(2n)是所 在属染色体基数 (x) 的二倍(即通常所指的二倍体); 多倍体则为染色体基数 $(\mathrm{x}$ )的 3 倍及 3 倍以上(主要是 指新多倍体)。后来Grant等(1963)假定配子染色体数 超过13的那些种大部分都是多倍体, 而小于13的则 以二倍体为主。Goldblatt (1980)认为Grant等(1963) 的方法太保守, 认为配子染色体数等于或大于 11 的 被子植物都有多倍性, 甚至有些数目较低的植物也 是由多倍体祖先衍生而来。Goldblatt (1980)的多倍 体概念包括了各种类型的多倍体。为了对多倍体进 行全面比较, 本文同时对新老多倍体进行统计分 析, 新多倍体采用Stebbins的方法, 如果一个种同 时有二倍体和多倍体的报道, 视为多倍体进行统 计。古多倍体的统计则综合Goldblatt (1980)与Lewis (1980)的方法, 把凡是染色体数 $2 n \geq 22$ 的二倍体 都认为是古多倍体。

\section{2 染色体倍性统计结果与分析}

\section{1 多倍体整体比例}

通过收集青藏高原和横断山被子植物所有染 色体报道数据, 总共得到 1,491 条染色体记录, 来自 57 科 223 属 1,001 种(包括变种, 表 1 , 附录 1 ), 主要集 中在菊科、百合科、毛茛科、龙胆科、豆科、蓄薇 科、兰科、报春花科、十字花科和伞形科。被子植 物新多倍体比例约为 $23 \%$, 与聂泽龙 $(2002)^{\circledR}$ 对横断 山区被子植物染色体数据的统计结果非常相似(458 种, 新多倍体所占比例为 $24.0 \%$ )。与Khatoon 和 Ali (1993)基于喜马拉雅西部的巴基斯坦地区的被子 植物染色体数据所进行的统计分析结果也很

(1) 聂泽龙 (2002) 横断山区被子植物细胞地理学初探. 硕士学位论文, 中国科学院昆明植物研究所, 昆明. 
表1 青藏高原与横断山被子植物区系染色体数目及倍性比例按分布型、生活型及海拔分布情况统计

Table 1 A summary of ploidy distribution of angiosperms from the Qinghai-Tibet Plateau and Hengduan Mountains according to their areal-types, life forms, and altitudes

\begin{tabular}{|c|c|c|c|c|c|}
\hline & \multirow{2}{*}{$\begin{array}{l}\text { 报道条数 } \\
\text { No. of counts }\end{array}$} & \multicolumn{4}{|c|}{ 种数 No. of species (\%) } \\
\hline & & $\begin{array}{l}\text { 总数 } \\
\text { Total }\end{array}$ & $\begin{array}{l}\text { 新多倍体 } \\
\text { Neopolyploids }\end{array}$ & $\begin{array}{l}\text { 古多倍体 } \\
\text { Paleopolyploids }\end{array}$ & $\begin{array}{l}\text { 二倍体 } \\
\text { Diploids }\end{array}$ \\
\hline \multicolumn{6}{|l|}{ 分布型 Areal-type } \\
\hline 世界分布 Cosmopolitan & 177 & 139 & $38(27.3)$ & $21(15.1)$ & $80(57.6)$ \\
\hline 泛热带分布 Pantropic & 37 & 33 & $3(9.1)$ & $15(45.5)$ & $15(45.5)$ \\
\hline $\begin{array}{l}\text { 东亚(热带、亚热带)及热带南美间断 East Asia (Tropical } \\
\& \text { Subtropical) \& Tropical South America disjuncted }\end{array}$ & 1 & 1 & $0(0.0)$ & $1(100)$ & $0(0.0)$ \\
\hline 旧世界热带分布 Old World Tropics & 111 & 83 & $26(31.3)$ & $28(33.7)$ & $29(34.9)$ \\
\hline $\begin{array}{l}\text { 热带亚洲至热带大洋洲分布 Tropical Asia to Tropical } \\
\text { Australasia Oceania }\end{array}$ & & 5 & $2(40.0)$ & $2(40.0)$ & $1(20.0)$ \\
\hline $\begin{array}{l}\text { 热带亚洲至热带非洲分布 Tropical Asia to Tropical Af- } \\
\text { rica }\end{array}$ & 18 & 11 & $2(18.2)$ & $4(36.4)$ & $5(45.5)$ \\
\hline $\begin{array}{l}\text { 热带亚洲(印度-马来西亚)分布 Tropical Southeast Asia } \\
\text { to Indo-Malaya \& Tropical Southwest Pacific Islands }\end{array}$ & 43 & 26 & $7(26.9)$ & $16(61.5)$ & $3(11.5)$ \\
\hline 北温带分布 North Temperate & 838 & 516 & $118(22.9)$ & $185(35.8)$ & $213(41.3)$ \\
\hline $\begin{array}{l}\text { 东亚和北美洲间断分布 East Asia \& North America dis- } \\
\text { juted }\end{array}$ & 18 & 12 & $2(16.7)$ & $6(50)$ & $4(33.3)$ \\
\hline 旧世界温带 Old World Temperate & 11 & 11 & $2(18.2)$ & $3(27.3)$ & $6(54.5)$ \\
\hline 温带亚洲分布 Temperate Asia & 29 & 21 & $5(23.8)$ & $6(28.6)$ & $10(47.6)$ \\
\hline $\begin{array}{l}\text { 地中海区、西亚至中亚分布 Mediterranean \& West to } \\
\text { Central Asia }\end{array}$ & 1 & 1 & $0(0.0)$ & $0(0.0)$ & $1(100.0)$ \\
\hline 中亚分布 Central Asia & 21 & 17 & $3(17.6)$ & $6(35.3)$ & $8(47.1)$ \\
\hline 东亚分布 East Asia & 150 & 101 & $20(19.8)$ & $36(35.6)$ & $45(44.6)$ \\
\hline 中国特有分布 Endemic to China & 31 & 24 & $2(8.3)$ & $9(37.5)$ & $13(54.2)$ \\
\hline 小计 Subtotal & 1,491 & 1,001 & $230(23.0)$ & $338(33.7)$ & $433(43.3)$ \\
\hline \multicolumn{6}{|l|}{ 生活型 Life form } \\
\hline 一年生草本 Annual herb & 139 & 96 & $19(19.8)$ & $18(18.8)$ & $59(61.5)$ \\
\hline 多年生草本 Perennial herb & 1,208 & 796 & $182(22.9)$ & $289(36.3)$ & $325(40.8)$ \\
\hline 木本 Woody & 144 & 109 & $29(26.6)$ & $31(28.4)$ & $49(45.0)$ \\
\hline 小计 Subtotal & 1,491 & 1,001 & $230(23.0)$ & $338(33.7)$ & $433(43.3)$ \\
\hline \multicolumn{6}{|l|}{ 海拔 Altitude } \\
\hline$<1,000 \mathrm{~m}$ & 51 & 38 & $13(34.2)$ & $7(18.4)$ & $18(47.4)$ \\
\hline $1,000-2,000 \mathrm{~m}$ & 145 & 101 & $28(27.7)$ & $25(24.8)$ & $48(47.5)$ \\
\hline $2,000-3,000 \mathrm{~m}$ & 222 & 156 & $24(15.4)$ & $77(49.4)$ & $55(35.3)$ \\
\hline $3,000-4,000 \mathrm{~m}$ & 411 & 255 & $65(25.5)$ & $102(40)$ & $88(34.5)$ \\
\hline $4,000-5,000 \mathrm{~m}$ & 196 & 122 & $27(22.1)$ & $35(28.7)$ & $60(49.2)$ \\
\hline$>5,000 \mathrm{~m}$ & 9 & 6 & $3(50.0)$ & $1(16.7)$ & $2(33.3)$ \\
\hline 小计 Subtotal & 1,034 & 678 & $160(23.6)$ & $247(36.4)$ & $271(40.0)$ \\
\hline
\end{tabular}

相似，在其所列举的 1,772 种被子植物中新多倍体 约占 $30.1 \%$ 。这进一步加强了我们对青藏高原与横 断山地区现有染色体倍性统计结果的可信度, 表明 整个喜马拉雅地区的被子植物多倍体分布比例比 较低。

从整体来看，青藏高原与横断山被子植物的新 多倍体比例 $(23 \%)$ 相对来说偏低, 如果把古多倍体 也包括进来，则多倍体的比例可占到 $56.7 \%$ (表1)。
与整个被子植物界多倍体的比例接近(估计在 50-70\%左右)。Morton (1993)曾对非洲喀麦隆山植 物的多倍性进行估计，仅新多倍体频率就达 $52.9 \%$, 如果把古多倍体成分包括进去, 则比例更高。因此 从本文收集的资料来看, 整个青藏高原和横断山区 的被子植物多倍体比例是偏低的, 尤其是新多倍体 比例。但由于青藏高原与横断山8,000-10,000种被 子植物中，目前有染色体资料的种只占 $1 / 10$ 左右， 
与其研究地位极不相称, 因此对这一地区的细胞学 研究工作还需进一步加强。

\section{2 按属分布型的染色体倍性分布}

北温带成分是这里植物区系的主要成分, 也是 特征成分。从表 1 可见, 北温带分布型类群报道的种 类最多, 在所有收集的 1,001 种植物中, 属分布型为 北温带成分的有 516 种, 占了一半以上(表1), 如果 加上其他温带分布型, 则远远超过一半。青藏高原 及横断山的植物区系基本上为北温带性质, 其重要 性不仅在于它具有异常丰富的植物种类和复杂多 样的区系成分, 更在于其广泛分布的北温带成分和 突出的东亚成分和中国-喜马拉雅成分 (Wu，1988; 李锡文和李捷, 1993)。因此本文所收集的染色体数 据也表明我国西南地区植物区系为温带性质, 特别 是北温带性质。北温带分布型的倍性分布比例与整 体水平非常接近, 新多倍体约有 $22.9 \%$, 古多倍体 比例为 $35.8 \%$ (表 1$)$ 。

其次，东亚分布型的报道数是除世界广布型外 仅次于北温带分布型的成分, 位列第三(表1)。东亚 成分和中国特有成分是西南地区被子植物区系的 特征成分, 其中东亚成分中的中国-喜马拉雅成分 是由其他温带成分适应于高山环境的衍生结果(李 锡文和李捷, 1993; 孙航, 2002)。青藏高原和横断山 具有明显的东亚植物区系的烙印(孙航和李志敏, 2003)。本地区是东亚成分的主要形成中心之一, 就 地演化形成了一些中小型的特有属。因此研究本类 型植物的细胞学特征也许更能反映我国西南植物 区系成分的染色体倍性与进化特点。本次统计的东 亚成分的倍性分布比例分别为 $19.8 \%$ (新多倍体), $35.6 \%$ (古多倍体)和 $44.6 \%$ (二倍体), 其中新多倍体 比例略低于北温带成分 (表1), 这可能是因为本类型 大都是从北温带成分就地演化而来, 故而具有相似 的倍性分布规律。

\section{3 植物生活型与染色体倍性分布}

在所统计的 1,001 种青藏高原和横断山的被子 植物中, 多年生草本植物有 796种, 约占总数的 $80 \%$ ，一年生草本植物 96 种，约占 $9.6 \%$, 木本植物 109种, 占 $10.9 \%$ 。也就是说, 该地区已有染色体数 目报道的被子植物绝大部分为多年生草本植物, 它 们是该地区被子植物重要的生活型, 可能更能适应 这里严酷的生境。因此, 多年生草本植物的多倍性 更能反映我国西南高山地区被子植物区系的染色
体进化特点。多年生草本植物的新多倍体、古多倍 体与二倍体的比例分别为 $22.9 \% 、 36.3 \%$ 与 $40.8 \%$, 这与总的统计情况也非常相似。另外, 新多倍体主 要见于多年生植物和木本植物(其中多年生草本植 物新多倍体比例为 $22 \%$ ，木本植物的为 $26.6 \%)$, 一 年生植物则多为二倍体种，比例高达 $61.5 \%$ (表 1$)$ 。

\section{4 多倍体沿海拔的分布规律}

本研究中有海拔记录的染色体报道的种类共 有 678 种 1,034 条记录, 经统计发现多倍体的比例与 海拔没有明显的相关性(表1)。从新多倍体分布情况 来看, 在海拔 $5,000 \mathrm{~m}$ 以上和 $1,000 \mathrm{~m}$ 以下新多倍体 的比例较高，分别是 $50 \%$ 和 $34.2 \%$, 而在海拔 2,000-3,000 $\mathrm{m}$ 之间的比例最低, 仅为 $15.4 \%$, 其他 两个海拔段分别为 $22.1 \%$ 和 $27.7 \%$ 。但是海拔 2,000-3,000 $\mathrm{m}$ 段古多倍体所占比例最高, 约为 $49.4 \%$, 其次是海拔 3,000-4,000 $\mathrm{m}$ 段, 古多倍体占 到 $40 \%$, 说明海拔 $2,000-4,000 \mathrm{~m}$ 段植物属于古老成 分的比较多。但由于目前这一地区染色体资料并不 是很多, 需要更多的数据来进一步验证这些结果。

\section{3 青藏高原与横断山被子植物区系成分多 样化的细胞学演化途径}

被子植物在青藏高原和横断山区得到了充分 的发展和演化, 这里植物种类丰富, 并富有大量特 有种(吴征镒和王荷生，1983; 李锡文和李捷，1993; 孙航和周浙昆, 1996)。在它们长期的发展分化过程 中必然有许多错综复杂的染色体进化样式。无论是 从总体情况来看, 还是对其主要的成分比如北温带 成分, 以及其主要的生活型(多年生草本), 或者从 其海拔分布情况来看, 目前的数据表明整个青藏高 原的被子植物多倍化频率都是非常低的，高基数的 二倍体和真正的二倍体(低基数)都占有相当大的比 例(表1), 我们的统计结果揭示多倍体可能并非植物 适应高寒生境的唯一途径, 这一地区植物区系在细 胞学上的演化机制是多样化的, 新多倍化、古多倍 化以及二倍体水平上的物种演化都是可能的重要 途径。

从许多被子植物的重要类群和特有类群的染 色体数据可以看出(表 2,3 ), 这一地区被子植物细胞 学演化的这几种方式都比较活跃。本地区被子植物 染色体报道种数在 10 种以上的属有 27 属, 552 种, 占 已有报道种类的一半以上，新多倍体的分布在这些 
表2 报道种类 10 种以上的属的倍性分布情况

Table 2 Frequency of ploidy distribution of genus counted with more than 10 species

\begin{tabular}{|c|c|c|c|c|c|c|}
\hline \multirow{2}{*}{$\begin{array}{l}\text { 科名 } \\
\text { Family }\end{array}$} & \multirow{2}{*}{$\begin{array}{l}\text { 属名 } \\
\text { Genus }\end{array}$} & \multirow{2}{*}{$\begin{array}{l}\text { 报道条数 } \\
\text { No. of counts }\end{array}$} & \multicolumn{4}{|c|}{ 种数 No. of species (\%) } \\
\hline & & & $\begin{array}{l}\text { 总数 } \\
\text { Total }\end{array}$ & $\begin{array}{l}\text { 新多倍体 } \\
\text { Neopolyploids }\end{array}$ & $\begin{array}{l}\text { 古多倍体 } \\
\text { Paleopolyploids }\end{array}$ & $\begin{array}{l}\text { 二倍体 } \\
\text { Diploids }\end{array}$ \\
\hline 伞形科 Apiaceae & 柴胡属 Bupleurum & 15 & 12 & $1(8.3)$ & $0(0.0)$ & $11(91.7)$ \\
\hline 伞形科 Apiaceae & 独活属 Heracleum & 34 & 16 & $2(12.5)$ & $14(87.5)$ & $0(0.0)$ \\
\hline 伞形科 Apiaceae & 葈本属 Ligusticum & 12 & 11 & $2(18.2)$ & $9(81.8)$ & $0(0.0)$ \\
\hline 天门冬科 Asparagaceae & 黄精属 Polygonatum & 27 & 18 & $3(16.7)$ & $14(77.8)$ & $1(5.6)$ \\
\hline 菊科 Asteraceae & 香青属 Anaphalis & 37 & 18 & $15(83.3)$ & $3(16.7)$ & $0(0.0)$ \\
\hline 菊科 Asteraceae & 火线草属 Leontopodium & 20 & 13 & $7(53.8)$ & $6(46.2)$ & $0(0.0)$ \\
\hline 菊科 Asteraceae & 畭吾属 Ligularia & 20 & 17 & $1(5.9)$ & $16(94.1)$ & $0(0.0)$ \\
\hline 菊科 Asteraceae & 风毛菊属 Saussurea & 50 & 41 & $2(4.9)$ & $39(95.1)$ & $0(0.0)$ \\
\hline 紫葳科 Bignoniaceae & 角蒿属 Incarvillea & 15 & 12 & $0(0.0)$ & $12(100.0)$ & $0(0.0)$ \\
\hline 桔梗科 Campanulaceae & 蓝钟花属 Cyananthus & 23 & 14 & $2(14.3)$ & $0(0.0)$ & $12(85.7)$ \\
\hline 豆科 Fabaceae & 黄耆属 Astragalus & 12 & 12 & $2(16.7)$ & $0(0.0)$ & $10(83.3)$ \\
\hline 龙胆科 Gentianaceae & 龙胆属 Gentiana & 55 & 43 & $7(16.3)$ & $18(41.9)$ & $18(41.9)$ \\
\hline 鸢尾科 Iridaceae & 煘尾属 Iris & 13 & 10 & $0(0.0)$ & $10(100.0)$ & $0(0.0)$ \\
\hline 百合科 Liliaceae & 芴属 Allium & 91 & 35 & $14(40.0)$ & $3(8.6)$ & $18(51.4)$ \\
\hline 百合科 Liliaceae & 百合属 Lilium & 69 & 25 & $2(8.0)$ & $23(92.0)$ & $0(0.0)$ \\
\hline 百合科 Liliaceae & 豹子花属 Nomocharis & 23 & 11 & $1(9.1)$ & $10(90.9)$ & $0(0.0)$ \\
\hline 百合科 Liliaceae & 重楼属 Paris & 27 & 18 & $1(5.6)$ & $0(0.0)$ & $17(94.4)$ \\
\hline 列当科 Orobanchaceae & 马先蒿属 Pedicularis & 21 & 21 & $0(0.0)$ & $0(0.0)$ & $21(100.0)$ \\
\hline 禾本科 Poaceae & 我观观草属 Roegneria & 26 & 13 & $13(100.0)$ & $0(0.0)$ & $0(0.0)$ \\
\hline 报春花科 Primulaceae & 报春花属 Primula & 25 & 18 & $0(0.0)$ & $13(72.2)$ & $5(27.8)$ \\
\hline 毛茛科 Ranunculaceae & 乌头属 Aconitum & 71 & 45 & $9(20.0)$ & $0(0.0)$ & $36(80.0)$ \\
\hline 毛茛科 Ranunculaceae & 银莲花属 Anemone & 11 & 10 & $1(10.0)$ & $0(0.0)$ & $9(90.0)$ \\
\hline 毛莨科 Ranunculaceae & 翠雀属 Delphinium & 100 & 56 & $2(3.6)$ & $0(0.0)$ & $54(96.4)$ \\
\hline 毛茛科 Ranunculaceae & 毛莨属 Ranunculus & 17 & 15 & $10(66.7)$ & $0(0.0)$ & $5(33.3)$ \\
\hline 蓠薇科 Rosaceae & 苹果属 Malus & 22 & 11 & $6(54.5)$ & $5(45.5)$ & $0(0.0)$ \\
\hline 蓄薇科 Rosaceae & 悬钩子属 Rubus & 29 & 27 & $11(40.7)$ & $0(0.0)$ & $16(59.3)$ \\
\hline 虎耳草科 Saxifragaceae & 虎耳草属 Saxifraga & 10 & 10 & $4(40.0)$ & $2(20.0)$ & $4(40.0)$ \\
\hline
\end{tabular}

类群中的比例大致可以划分为 3 个区段(表2)。其中 高比例的有8属, 即香青属(Anaphalis)、火线草属 (Leontopodium)、葱属(Allium)、苹果属(Malus)、悬 钩子属 $($ Rubus $)$ 、毛莨属(Ranunculus)、我观草属 (Roegneria) 和虎耳草属(Saxifraga), 每个属的新多 倍体比例都达到 $40 \%$ 以上，其中鹅观草属全为新多 倍体; 新多倍体比例居中的有 7 属, 即乌头属 (Aconitum) 、黄耆属 (Astragalus) 、蓝钟花属 (Cyananthus) 、龙胆属 (Gentiana) 、葈本属 (Ligusticum)、独活属 (Heracleum) 和黄精属 (Polygonatum), 这些属的新多倍体比例在12.5-20\% 之间; 新多倍体比例相对比较低的有 12 属, 即银莲 花属 (Anemone)、翠雀属 (Delphinium)、柴胡属 (Bupleurum)、角蒿属(Incarvillea)、或尾属(Iris)、夢
吾属 (Ligularia)、风毛菊属 (Saussurea)、百合属 (Lilium)、豹子花属(Nomocharis)、重楼属(Paris)、 马先蒿属(Pedicularis)和报春花属(Primula), 这些 属的新多倍体比例在 $0-10 \%$ 之间。新多倍体比较少 的属往往具有较高的古多倍体或者二倍体比例, 比 如角蒿属和感尾属全为古多倍体, 而马先蒿属和重 楼属等多为二倍体(表2)。

从科水平来看, 染色体报道种数超过 10 种的共 有 20 科(表 3 )。新多倍体比例 $40 \%$ 以上的有 5 科：蓄薇 科、虎耳草科、天南星科、茄科和禾本科, 特别是 禾本科和茄科, 分别为 $92.6 \%$ 和 $81.8 \%$; 新多倍体比 例居中的有 8 科: 桔梗科、天门冬科、毛茛科、龙胆 科、菊科、百合科、蓼科和兰科，新多倍体比例在 16.7-26.9\%之间; 新多倍体比例偏少的有7科: 紫葳 
表3 报道种类10种以上的科的倍性分布情况统计表

Table 3 Frequency of ploidy distribution of family counted with more than 10 species

\begin{tabular}{|c|c|c|c|c|c|c|}
\hline \multirow[t]{2}{*}{$\begin{array}{l}\text { 科名 } \\
\text { Family }\end{array}$} & \multirow{2}{*}{$\begin{array}{l}\text { 属数 } \\
\text { No. of } \\
\text { genus }\end{array}$} & \multirow{2}{*}{$\begin{array}{l}\text { 报道条数 } \\
\text { No. of } \\
\text { counts }\end{array}$} & \multicolumn{4}{|c|}{ 种数 No. of species (\%) } \\
\hline & & & $\begin{array}{l}\text { 总数 } \\
\text { Total }\end{array}$ & $\begin{array}{l}\text { 新多倍体 } \\
\text { Neopolyploids }\end{array}$ & $\begin{array}{l}\text { 古多倍体 } \\
\text { Paleopolyploids }\end{array}$ & $\begin{array}{l}\text { 二倍体 } \\
\text { Diploids }\end{array}$ \\
\hline 伞形科 Apiaceae & 13 & 100 & 67 & $7(10.4)$ & $40(59.7)$ & $20(29.9)$ \\
\hline 天南星科 Araceae & 6 & 19 & 15 & $7(46.7)$ & $7(46.7)$ & $1(6.7)$ \\
\hline 天门冬科 Asparagaceae & 4 & 54 & 30 & $5(16.7)$ & $24(80.0)$ & $1(3.3)$ \\
\hline 菊科 Asteraceae & 28 & 200 & 149 & $35(23.5)$ & $75(50.3)$ & $39(26.2)$ \\
\hline 紫蒇科 Bignoniaceae & 1 & 15 & 12 & $0(0.0)$ & $12(100.0)$ & $0(0.0)$ \\
\hline 十字花科 Brassicaceae & 12 & 29 & 22 & $3(13.6)$ & $0(0.0)$ & $19(86.4)$ \\
\hline 桔梗科 Campanulaceae & 3 & 28 & 18 & $3(16.7)$ & $2(11.1)$ & $13(72.2)$ \\
\hline 豆科 Fabaceae & 14 & 67 & 58 & $4(6.9)$ & $3(5.2)$ & $51(87.9)$ \\
\hline 龙胆科 Gentianaceae & 7 & 70 & 58 & $11(19.0)$ & $21(36.2)$ & $26(44.8)$ \\
\hline 㫭尾科 Iridaceae & 1 & 13 & 10 & $0(0.0)$ & $10(100.0)$ & $0(0.0)$ \\
\hline 百合科 Liliaceae & 16 & 251 & 114 & $27(23.7)$ & $49(43.0)$ & $38(33.3)$ \\
\hline 兰科 Orchidaceae & 12 & 37 & 26 & $7(26.9)$ & $19(73.1)$ & $0(0.0)$ \\
\hline 列当科 Orobanchaceae & 1 & 21 & 21 & $0(0.0)$ & $0(0.0)$ & $21(100.0)$ \\
\hline 禾本科 Poaceae & 6 & 47 & 27 & $25(92.6)$ & $1(3.7)$ & $1(3.7)$ \\
\hline 蓼科 Polygonaceae & 2 & 17 & 12 & $3(25.0)$ & $6(50.0)$ & $3(25.0)$ \\
\hline 报春花科 Primulaceae & 3 & 40 & 24 & $2(8.3)$ & $13(54.2)$ & $9(37.5)$ \\
\hline 毛茛科 Ranunculaceae & 22 & 247 & 159 & $29(18.2)$ & $1(0.6)$ & $129(81.1)$ \\
\hline 蓄薇科 Rosaceae & 6 & 61 & 47 & $19(40.4)$ & $8(17.0)$ & $20(42.6)$ \\
\hline 虎耳草科 Saxifragaceae & 5 & 25 & 23 & $10(43.5)$ & $3(13.0)$ & $10(43.5)$ \\
\hline 茄科 Solanaceae & 7 & 14 & 11 & $9(81.8)$ & $1(9.1)$ & $1(9.1)$ \\
\hline
\end{tabular}

科、盛尾科、列当科、豆科、报春花科、伞形科和 十字花科, 新多倍体比例在0-13.6\%之间, 特别是 紫藏科、衲尾科和列当科, 没有新多倍体出现。

当然这几种方式不是绝对的, 有时有交叉重叠 现象。例如温带分布型的黄耆属和乌头属植物主要 为二倍体水平上演化, 但也有少数的新多倍化现象 出现(黎斌等, 2004; Yuan \& Yang, 2006); 而以横断 山区为其分化中心和分布中心的葍本属和黄精属 (王文采, 1993), 为染色体基数比较高的古多倍体, 同时演化出二倍体、四倍体和六倍体等(Zhou et al, 2008; Deng et al, 2009), 说明它们在早期多倍体二 倍化后又进行新一轮的多倍化过程, 进化非常迅速 和激烈。

多倍体一般被认为比其二倍体亲本具有更好 的忍耐严酷自然条件的能力(Stebbins, 1971，1980; Abbott \& Brochmann, 2003; Brochmann et al, 2004)。 但后来发现情况并不完全如此(Nie et al, 2005; Tkach et al, 2014), 本文同样发现多倍体比例在高 山地区并不占优势。这可能一方面因为植物多倍体
与其本身内在因素与环境条件等各个方面息息相 关, 另一方面植物适应环境条件的方式也是多种多 样的。从本地区大量的二倍体广布属及许多特有二 倍体属种可以看出(表1), 被子植物二倍体水平上的 适应机制在这里是非常成功的。虽然青藏高原复杂 的生境为这里的植物提供了很好的演化场所(吴征 镒和王荷生, 1983; Boufford \& Dyck, 2000), 但由于 该地区特殊的地质历史背景(莫宣学和潘桂棠, 2006), 极其缓慢的抬升过程一方面有利于植物多 倍化，同时也让植物有机会选择其他的进化方式， 如在二倍体水平上染色体结构变化可能也是该地 区被子植物的一条重要的进化途径, 大量的二倍体 特有种及二倍体特有属便是一个很好的例证。另外, 从古多倍体占优势的类群可以看出青藏高原被子 植物多倍化事件可能较多发生于地质抬升早期阶 段的就地演化, 或者外地迁入的一些高基数的类 群。由于本地区早期的地质抬升过程中环境变化程 度更大, 生境的改变更迅速, 更有利于早期多倍体 的形成。 
综上所述, 现有数据表明青藏高原和横断山区 新多倍体比例不占优势, 古多倍体和二倍体同时占 有较大的比重, 这种倍性分布的平均性, 反映了本 地区染色体进化的复杂机制, 这可能与该地区复杂 的地质历史条件和地形地貌有关。被子植物染色体 在该地区上演了各种可能的进化途径, 包括二倍体 水平的染色体进化、非整倍性变化及新老多倍化方 面等等, 甚至在一个类群内部也可能同时选择好几 种方式。但由于现有染色体资料还比较缺乏, 同时 人们越来越趋向于认为被子植物染色体进化是一 个非常复杂的系统工程, 因此对本地区被子植物区 系全面的倍性与地理分布情况及具体的染色体进 化机制与途径等, 现在下结论还为时过早, 还需要 有大量的研究工作来论证这方面的推测。

\section{参考文献}

Abbott RJ, Brochmann C (2003) History and evolution of the arctic flora: in the footsteps of Eric Hulten. Molecular Ecology, 12, 299-313.

Boufford DE, Dyck PPV (2000) South-Central China. In: Hotspots: Earth's Biologically Richest and most Endangered Terrestrial Ecoregions (eds Mittermeier RA, Myers N, Mittermeier CG), pp. 338-351. Graphic Arts Center Publishing Company, Portland.

Brochmann C, Brysting AK, Alsos IG, Borgen L, Grundt HH, Scheen A, Elven R (2004) Polyploidy in arctic plants. Biological Journal of the Linnean Society, 82, 521-536.

Deng XY, Wang Q, He XJ (2009) Karyotypes of 16 populations of eight species in the genus Polygonatum (Asparagaceae) from China. Botanical Journal of the Linnean Society, 159, 245-254.

Goldblatt P (1980) Polyploidy in angiospermum: monocotyledons. In: Polyploidy: Biological Relevance (ed. Lewis WH), p. 219. Springer, New York.

Grant JK, De DC, Biochimie SBD (1963) Methods of Separation of Subcellular Structural Components. Cambridge University Press, Cambridge.

Hong DY (1990) Plant Cytotaxonomy. Science Press, Beijing. (in Chinese) [洪德元 (1990) 植物细胞分类学. 科学出版 社, 北京.]

Justin R, Douglas WS (2002) Neopolyploidy in flowering plants. Annual Review of Ecology and Systematics, 33, 589-639.

Khatoon S, Ali SI (1993) Chromosome Atlas of the Angiosperms of Pakistan. BCC \& T Press, Karachi.

Levin DA (1983) Polyploidy and novelty in flowering plants. The American Naturalist, 122, 1-25.

Lewis WH (1980) Polyploidy: Biological Relevance. Springer, New York.

Li B, Chang ZY, Wu ZH, Xu LR (2004) A karyotype study of six Astragalus species from China. Acta Botanica Bore-
ali-Occidentalia Sinica, 24, 711-715. (in Chinese with English abstract) [黎斌, 常朝阳, 吴振海, 徐朗然 (2004) 国 产6种黄耆属植物的核型研究. 西北植物学报, 24 , 711-715.]

Li XW, Li J (1993) A preliminary floristic study on the seed plants from the region of Hengduan Mountain. Acta Botanica Yunnanica, 15, 217-231. (in Chinese with English abstract) [李锡文, 李捷 (1993) 横断山脉地区种子植物 区系的初步研究. 云南植物研究, 15, 217-231.]

Masterson J (1994) Stomatal size in fossil plants: evidence for polyploidy in majority of angiosperms. Science, 264, 421-424.

Mo XX, Pan GT (2006) From the Tethys to the formation of the Qinghai-Tibet Plateau: constrained by tectono-magmatic events. Earth Science Frontiers, 13(6), 43-51. (in Chinese with English abstract) [莫宣学, 潘桂棠 (2006) 从特提斯 到青藏高原形成：构造-岩浆事件的约束. 地学前缘, 13(6), 43-51.]

Morton JK (1993) Chromosome numbers and polyploidy in the flora of Cameroons Mountain. Opera Botany, 121, 159-172.

Myers N, Mittermeier RA, Mittermeier CG, Fonseca GABD, Kent J (2000) Biodiversity hotspots for conservation priorities. Nature, 403, 853-858.

Nie ZL, Wen J, Gu ZJ, Boufford DE, Sun H (2005) Polyploidy in the flora of the Hengduan Mountains hotspot, southwestern China. Annals of the Missouri Botanical Garden, 92, 275-306.

Ohba H (1988) The alpine flora of the Nepal Himalayas: an introductory note. In: The Himalayan Plants, Vol. 1. (eds Ohba H, Malla SB), pp. 19-46. University of Tokyo Press, Tokyo.

Otto SP (2007) The evolutionary consequences of polyploidy. Cell, 131, 452-462.

Soltis DE, Albert VA, Mack JL, Bell CD, Paterson AH, Zheng CF, Sankoff D, Pamphilis CW, Wall PK, Soltis PS (2009) Polyploidy and angiosperm diversification. American Journal of Botany, 96, 336-348.

Soltis DE, Soltis PS, Tate JA (2004) Advances in the study of polyploidy since plant speciation. New Phytologist, 161, 173-191.

Stebbins GL (1950) Variation and Evolution in Plants. Columbia University Press, New York.

Stebbins GL (1938) Cytogenetic studies in Paeonia. II. The cytology of the diploid species and hybrids. Genetics, 23, $83-110$.

Stebbins GL (1971) Chromosomal Evolution in Higher Plants. Edward Arnold Ltd., London.

Stebbins GL (1980) Polyploidy in plants: unsolved problems and prospects. In: Polyploidy: Biological Relevance (ed. Lewis WH), pp. 495-520. Springer, New York.

Sun H (2002) Tethys retreat and Himalayas-Hengduanshan Mountains uplift and their significance on the origin and development of the Sino-Himalayan elements and alpine flora. Acta Botanica Yunnanica, 24, 273-288. (in Chinese with English abstract) [孙航 (2002) 古地中海退却与喜马 
拉雅一横断山的隆起在中国喜马拉雅成分及高山植物区 系的形成与发展上的意义. 云南植物研究, 24, 273-288.]

Sun H, Li ZM (2003) Qinghai-Tibet Plateau uplift and its impact on Tethys flora. Advance in Earth Sciences, 18, 852-862. (in Chinese with English abstract) [孙航, 李志敏 (2003) 古地中海植物区系在青藏高原隆起后的演变和发 展. 地球科学进展, 18, 852-862.]

Sun H, Zhou ZK (1996) The characters and origin of the flora from the big bend gorge of Yalutsangpu (Brahmabutra) River, eastern Himalayas. Acta Botanica Yunnanica, 18, 185-204. (in Chinese with English abstract) [孙航, 周浙昆 (1996) 喜马拉雅东部雅鲁藏布江大峡湾河谷地区植物区 系的特点及来源. 云南植物研究, 18, 185-204.]

Tkach N, Ree RH, Kuss P, Röser M, Hoffmann MH (2014) High mountain origin, phylogenetics, evolution, and niche conservatism of arctic lineages in the hemiparasitic genus Pedicularis (Orobanchaceae). Molecular Phylogenetics and Evolution, 76(8), 75-92.

Wang WT (1993) Vascular Plants of the Hengduan Mountains, Vol. 1. Science Press, Beijing. [王文采 (1993) 横断山区 维管植物, 上册. 科学出版社, 北京.]

Wu SG, Yang YP, Fei Y (1995) On the flora of the alpine region in the Qinghai-Xizang (Tibet) Plateau. Acta Botanica Yunnanica, 17, 233-250. (in Chinese with English abstract)
[武素功, 杨永平, 费勇 (1995) 青藏高原高寒地区种子 植物区系的研究. 云南植物研究, 17, 233-250.]

Wu ZY (1988) Hengduan Mountains flora and her significance. Journal of Japanese Botany, 63, 297-311.

$\mathrm{Wu}$ ZY (1988) Origin and evolution of the flora of Tibet. In: Flora of Xizangica, Vol. 5 (ed. Wu ZY), pp. 874-902. Science Press, Beijing. (in Chinese) [吴征镒 (1988) 西藏植物 区系的起源及演化. 见: 西藏植物志, 第 5 卷 (吴征镒编), 874-902页. 科学出版社, 北京.]

Wu ZY (1991) The areal-types of Chinese genera of seed plants. Acta Botanica Yunnanica (Suppl. IV), 1-139. (in Chinese with English abstract) [吴征镒 (1991) 中国种子 植物属的分布区类型. 云南植物研究 (增刊IV), 1-139.]

Wu ZY, Wang HS (1983) Physical Geography of China: Phytogeography (I). Science Press, Beijing. (in Chinese) [吴征 镒, 王荷生 (1983) 中国自然地理: 植物地理(上册). 科 学出版社, 北京.]

Yuan Q, Yang QE (2006) Polyploidy in Aconitum subgenus Lycoctonum (Ranunculaceae). Botanical Journal of the Linnean Society, 150, 343-353.

Zhou J, Pu FD, Peng HJ, Pan YZ, Gong X (2008) Karyological studies of ten Ligusticum species (Apiaceae) from the Hengduan Mountains region of China. Caryologia, 61, 333-341.

(责任编委: 葛学军 责任编辑: 间文杰)

\section{附录 Supplementary Material}

\section{附录1 青藏高原与横断山被子植物染色体数据集}

Appendix 1 Chromosome dataset of angiosperms from the Qinghai-Tibet Plateau and Hengduan Mountains http://www.biodiversity-science.net/fileup/PDF/2016281-1.pdf 
王家坚, 彭智邦, 孙航，聂泽龙，孟盈. 青藏高原与横断山被子植物区系演化的细胞地理学特征. 生物多样性, 2017, 25 (2): 218-225.

http://www.biodiversity-science.net/CN/10.17520/biods.2016281

\section{附录1＼cjkstart青藏高原与横断山被子植物染色体数据集}

Appendix 1 Chromosome dataset of angiosperms from the Qinghai-Tibet Plateau and Hengduan Mountains

Comments: $\mathrm{n}$ = gametic or haploid chromosome number; $2 \mathrm{n}=$ somatic chromosome number; $\mathrm{x}=$ chromosome base number; $\mathrm{W}($ woody)=木本植物; PH (perennial herb) $=$ 多年生草本; $\mathrm{AH}$ (annual herb)=一年生草本; C (Cosmopolitan)=世界分布; P (Pantropic)=泛热带分布; TA (Tropical Asia)=热带亚洲分布; OWT (Old World Tropics)=旧世界热带分布; TA \& TA (Tropical Asia \& Trop. Australasia)=热带亚洲至热带大洋洲 分布; TA to TA (Trop. Asia to Trop. Africa)=热带亚洲至热带非洲分布; TA (Trop. Asia)=热带亚洲; NT (North Temperate)=北温带分布; EA \& NAD (E. Asia \& N. Amer. disjuncted)=东亚和北美洲间断分布; OWT (Old World Temperate)=旧世界温带分布; TA (Temp. Asia)=温带亚洲分布; M、WA to CA (Mediterranea, W. Asia to C. Asia)=地中海区、西亚至中亚分布; CA (C. Asia)=中亚分布; EA (E. Asia)=东亚分 布; EC (Endemic to China)=中国特有分布。

\begin{tabular}{|c|c|c|c|c|c|c|c|c|c|c|c|}
\hline 科名 Families & 属名 Genera & 种名 Species & 采集地点 Location & $\mathrm{n}$ & $2 n$ & $\mathrm{x}$ & $\begin{array}{l}\text { 倍性 } \\
\text { Ploidy }\end{array}$ & $\begin{array}{l}\text { 海拔 } \\
\text { Altitude } \\
\text { (m) }\end{array}$ & $\begin{array}{l}\text { 生活型 } \\
\text { Life form }\end{array}$ & $\begin{array}{l}\text { 分布型 } \\
\text { Areal-type }\end{array}$ & 参考文献 Reference \\
\hline $\begin{array}{l}\text { 菝葜科 } \\
\text { Smilacaceae }\end{array}$ & $\begin{array}{l}\text { 肖菝葜属 } \\
\text { Heterosmilax }\end{array}$ & H. yunnanensis Gagnep. & 四川峨眉山 Emei Mt., Sichuan & & 32 & 16 & $2 \mathrm{x}$ & 1,700 & $\mathrm{~W}$ & TA & 傅承新等, 1995a, b \\
\hline $\begin{array}{l}\text { 菝葜科 } \\
\text { Smilacaceae }\end{array}$ & 菝葜属 Smilax & S. chapaensis Gagnep. & 四川峨眉山 Emei Mt., Sichuan & & 32 & 16 & $2 \mathrm{x}$ & & $\mathrm{W}$ & $\mathrm{P}$ & 傅承新等, 1992 \\
\hline $\begin{array}{l}\text { 菝荰科 } \\
\text { Smilacaceae }\end{array}$ & 菝葜属 Smilax & S. chapaensis Gagnep. & 四川峨眉山 Emei Mt., Sichuan & & 32 & 16 & $2 \mathrm{x}$ & & $\mathrm{W}$ & $\mathrm{P}$ & 傅承新等, 1993 \\
\hline $\begin{array}{l}\text { 菝荰科 } \\
\text { Smilacaceae }\end{array}$ & 茏葜属 Smilax & S. menispermoidea A. DC. & 四川峨眉山 Emei Mt., Sichuan & & 32 & 16 & $2 \mathrm{x}$ & & $\mathrm{W}$ & $\mathrm{P}$ & 傅承新等, 1995a, b \\
\hline $\begin{array}{l}\text { 菝葜科 } \\
\text { Smilacaceae }\end{array}$ & 菝葜属 Smilax & S. tsinchengshanensis Wang & 四川峨眉山 Emei Mt., Sichuan & & 32 & 16 & $2 \mathrm{x}$ & 1,500 & W & $\mathrm{P}$ & 傅承新等, 1993 \\
\hline 百合科 Liliaceae & $\begin{array}{l}\text { 竹根七属 } \\
\text { Disporopsis }\end{array}$ & D. aspersa (Hua) Engl. & 四川峨眉山 Emei Mt., Sichuan & & 40 & 20 & $2 \mathrm{x}$ & & $\mathrm{PH}$ & $\mathrm{TA}$ & 顾志建等, 1990 \\
\hline 百合科 Liliaceae & $\begin{array}{l}\text { 竹根七属 } \\
\text { Disporopsis }\end{array}$ & D. fusco-picta Hance & 云南腾冲 Tengchong, Yunnan & & 40 & 20 & $2 \mathrm{x}$ & & PH & $\mathrm{TA}$ & 顾志建等, 1990 \\
\hline
\end{tabular}


王家坚, 彭智邦, 孙航, 聂泽龙, 孟盈. 青藏高原与横断山被子植物区系演化的细胞地理学特征. 生物多样性, 2017, 25 (2): 218-225.

http://www.biodiversity-science.net/CN/10.17520/biods.2016281

\begin{tabular}{|c|c|c|c|c|c|c|c|c|c|c|c|}
\hline 科名 Families & 属名 Genera & 种名 Species & 采集地点 Location & $\mathrm{n}$ & $2 n$ & $\mathrm{x}$ & $\begin{array}{l}\text { 倍性 } \\
\text { Ploidy }\end{array}$ & $\begin{array}{l}\text { 海拔 } \\
\text { Altitude } \\
\text { (m) }\end{array}$ & $\begin{array}{l}\text { 生活型 } \\
\text { Life form }\end{array}$ & $\begin{array}{l}\text { 分布型 } \\
\text { Areal-type }\end{array}$ & 参考文献 Reference \\
\hline 百合科 Liliaceae & 重楼属 Paris & P. axialis $\mathrm{H}$. $\mathrm{Li}$ & 四川雅安 Ya’an, Sichuan & & 12 & 6 & $2 \mathrm{x}$ & 1,350 & $\mathrm{PH}$ & OWT & 岳海霞, 2011 \\
\hline 百合科 Liliaceae & 重楼属 Paris & P. bashanensis F. T. Wang \& T. Tang & 云南大理 Dali, Yunnan & & 10 & 5 & $2 \mathrm{x}$ & & $\mathrm{PH}$ & OWT & $\begin{array}{l}\text { 顾志建和纳海燕, } \\
1986\end{array}$ \\
\hline 百合科 Liliaceae & 重楼属 Paris & P. cronquistii (Takhtajan) H. Li & 四川乐山 Leshan, Sichuan & & 10 & 5 & $2 \mathrm{x}$ & 1,750 & $\mathrm{PH}$ & OWT & 岳海霞, 2011 \\
\hline 百合科 Liliaceae & 重楼属 Paris & P. dulongensis H. Li \& S. Kurita & 云南贡山 Gongshan, Yunnan & & 72 & 18 & $4 \mathrm{x}$ & 1,300 & PH & NT & 顾志建等, 1992 \\
\hline 百合科 Liliaceae & 重楼属 Paris & P. fargesii Franch. & 四川峨眉山 Emei Mt., Sichuan & 5 & & 5 & $2 \mathrm{x}$ & & $\mathrm{PH}$ & OWT & 汤彦承等, 1984 \\
\hline 百合科 Liliaceae & 重楼属 Paris & P. forrestii (Takht.) H. Li & 云南大理 Dali, Yunnan & & 10 & 5 & $2 \mathrm{x}$ & & $\mathrm{PH}$ & OWT & $\begin{array}{l}\text { 顾志建和纳海燕, } \\
1986\end{array}$ \\
\hline 百合科 Liliaceae & 重楼属 Paris & P. forrestii (Takht.) H. Li & 云南贡山 Gongshan, Yunnan & & 10 & 5 & $2 \mathrm{x}$ & 1,320 & $\mathrm{PH}$ & OWT & 顾志建等, 1992 \\
\hline 百合科 Liliaceae & 重楼属 Paris & P. luquanensis $\mathrm{H}$. Li & 四川凉山 Liangshan, Sichuan & & 10 & 5 & $2 \mathrm{x}$ & 2,250 & $\mathrm{PH}$ & OWT & 岳海霞, 2011 \\
\hline 百合科 Liliaceae & 重楼属 Paris & P. mairei H. Lév. & 云南大理 Dali, Yunnan & & 10 & 5 & $2 \mathrm{x}$ & & $\mathrm{PH}$ & OWT & $\begin{array}{l}\text { 顾志建和纳海燕, } \\
1986\end{array}$ \\
\hline 百合科 Liliaceae & 重楼属 Paris & P. mairei H. Léveillé & 云南贡山 Gongshan, Yunnan & & 10 & 5 & $2 \mathrm{x}$ & 2,350 & $\mathrm{PH}$ & OWT & 顾志建等, 1992 \\
\hline 百合科 Liliaceae & 重楼属 Paris & P. mairei H. Léveillé & 四川绵阳 Mianyang, Sichuan & & 10 & 5 & $2 \mathrm{x}$ & 1,900 & PH & OWT & 岳海霞, 2011 \\
\hline 百合科 Liliaceae & 重楼属 Paris & P. marmorata Stearn & 云南大理 Dali, Yunnan & & 10 & 5 & $2 \mathrm{x}$ & & $\mathrm{PH}$ & OWT & $\begin{array}{l}\text { 顾志建和纳海燕, } \\
1986\end{array}$ \\
\hline 百合科 Liliaceae & 重楼属 Paris & P. marmorata Stearn & 四川雅安 Ya'an, Sichuan & & 10 & 5 & $2 \mathrm{x}$ & 1,650 & $\mathrm{PH}$ & OWT & 岳海霞, 2011 \\
\hline 百合科 Liliaceae & 重楼属 Paris & P. polyphylla Sm. & 四川峨眉山 Emei Mt., Sichuan & & 20 & 5 & $4 \mathrm{x}$ & & $\mathrm{PH}$ & OWT & Wang \& Xu, 1989 \\
\hline 百合科 Liliaceae & 重楼属 Paris & P. polyphylla Sm. & 四川汶川 Wenchuan, Sichuan & & 10 & 5 & $2 \mathrm{x}$ & & $\mathrm{PH}$ & OWT & Hong \& Zhu, 1987 \\
\hline 百合科 Liliaceae & 重楼属 Paris & P. Polyphylla var. alba & 四川雅安 Ya’an, Sichuan & & 10 & 5 & $2 \mathrm{x}$ & 1,900 & $\mathrm{PH}$ & OWT & 岳海霞, 2011 \\
\hline 百合科 Liliaceae & 重楼属 Paris & $\begin{array}{l}\text { P. polyphylla var. chinensis (Franch.) } \\
\text { H. Hara }\end{array}$ & 四川洪雅 Hongya, Sichuan & & 10 & 5 & $2 \mathrm{x}$ & 1,650 & $\mathrm{PH}$ & OWT & 岳海霞, 2011 \\
\hline 百合科 Liliaceae & 重楼属 Paris & P. polyphylla var. polyphylla & 四川都江堰 Dujiangyan, Sichuan & & 12 & 6 & $2 x$ & 1,350 & PH & OWT & 岳海霞, 2011 \\
\hline
\end{tabular}


王家坚, 彭智邦, 孙航, 聂泽龙, 孟盈. 青藏高原与横断山被子植物区系演化的细胞地理学特征. 生物多样性, 2017, 25 (2): 218-225.

http://www.biodiversity-science.net/CN/10.17520/biods.2016281

\begin{tabular}{|c|c|c|c|c|c|c|c|c|c|c|c|}
\hline 科名 Families & 属名 Genera & 种名 Species & 采集地点 Location & $\mathrm{n}$ & $2 n$ & $\mathrm{x}$ & $\begin{array}{l}\text { 倍性 } \\
\text { Ploidy }\end{array}$ & $\begin{array}{l}\text { 海拔 } \\
\text { Altitude } \\
(\mathrm{m})\end{array}$ & $\begin{array}{l}\text { 生活型 } \\
\text { Life form }\end{array}$ & $\begin{array}{l}\text { 分布型 } \\
\text { Areal-type }\end{array}$ & 参考文献 Reference \\
\hline 百合科 Liliaceae & 重楼属 Paris & P. polyphylla var. yunnanensis & 四川攀枝花 Panzhihua, Sichuan & & 10 & 5 & $2 \mathrm{x}$ & 1,350 & $\mathrm{PH}$ & OWT & 岳海霞, 2011 \\
\hline 百合科 Liliaceae & 重楼属 Paris & P. rugosa H. Li \& S. Kurita & 云南贡山 Gongshan, Yunnan & & 10 & 5 & $2 \mathrm{x}$ & 1,700 & $\mathrm{PH}$ & OWT & 顾志建等, 1992 \\
\hline 百合科 Liliaceae & 重楼属 Paris & P. thibetica Franch. & 云南大理 Dali, Yunnan & & 10 & 5 & $2 \mathrm{x}$ & & $\mathrm{PH}$ & OWT & $\begin{array}{l}\text { 顾志建和纳海燕, } \\
1986\end{array}$ \\
\hline 百合科 Liliaceae & 重楼属 Paris & P. thibetica Franchet & 四川雅安 Ya’an, Sichuan & & 10 & 5 & $2 \mathrm{x}$ & 1,900 & $\mathrm{PH}$ & OWT & 岳海霞, 2011 \\
\hline 百合科 Liliaceae & 重楼属 Paris & P. thibetica var. apetala Hand. -Mazz. & 云南贡山 Gongshan, Yunnan & & 10 & 5 & $2 \mathrm{x}$ & 1,500 & $\mathrm{PH}$ & OWT & 顾志建等, 1992 \\
\hline 百合科 Liliaceae & 重楼属 Paris & P. undulatis H. Li \& V. G. Soukup & 四川峨眉山 Emei Mt., Sichuan & & 10 & 5 & $2 \mathrm{x}$ & 2,100 & $\mathrm{PH}$ & OWT & 岳海霞, 2011 \\
\hline 百合科 Liliaceae & $\begin{array}{l}\text { 沿阶草属 } \\
\text { Ophiopogon }\end{array}$ & $\begin{array}{l}\text { O. angustifoliatus (Wang \& Tang) S. } \\
\text { C. Chen }\end{array}$ & 云南维西 Weixi, Yunnan & & 72 & 18 & $4 \mathrm{x}$ & 3,100 & $\mathrm{PH}$ & EA & 张芝玉, 1998 \\
\hline 百合科 Liliaceae & 延龄草属 Trillium & T. tschonoskii Maxim. & 四川峨眉山 Emei Mt., Sichuan & & 20 & 10 & $4 \mathrm{x}$ & & $\mathrm{PH}$ & $\begin{array}{l}\text { EA \& } \\
\text { NAD }\end{array}$ & Wang \& Xu, 1989 \\
\hline 百合科 Liliaceae & 延龄草属 Trillium & T. tschonoskii Maxim. & 四川峨眉山 Emei Mt., Sichuan & & 10 & 5 & $2 \mathrm{x}$ & & $\mathrm{PH}$ & $\begin{array}{l}\text { EA \& } \\
\text { NAD }\end{array}$ & 王淑芬, 1989 \\
\hline 百合科 Liliaceae & $\begin{array}{l}\text { 萱草属 } \\
\text { Hemerocallis }\end{array}$ & H. forrestii Diels & 云南丽江 Lijiang, Yunnan & & 22 & 12 & $2 \mathrm{x}$ & 3,200 & $\mathrm{PH}$ & OWT & $\begin{array}{l}\text { 熊治廷和陈心启, } \\
1998\end{array}$ \\
\hline 百合科 Liliaceae & $\begin{array}{l}\text { 萱草属 } \\
\text { Hemerocallis }\end{array}$ & H. multiflora Stout & 云南大理 Dali, Yunnan & & 33 & 11 & $3 \mathrm{x}$ & 2,500 & $\mathrm{PH}$ & OWT & $\begin{array}{l}\text { 熊治廷和陈心启, } \\
1998\end{array}$ \\
\hline 百合科 Liliaceae & $\begin{array}{l}\text { 萱草属 } \\
\text { Hemerocallis }\end{array}$ & H. plicata Stapf & 云南大理 Dali, Yunnan & & 22 & 11 & $2 \mathrm{x}$ & 2,300 & $\mathrm{PH}$ & OWT & $\begin{array}{l}\text { 熊治廷和陈心启, } \\
1998\end{array}$ \\
\hline 百合科 Liliaceae & 洼瓣花属 Lloydia & L. serotina (L.) Reich & 青海乐都 Ledu, Qinghai & & 48 & 8 & $6 \mathrm{x}$ & 4,600 & $\mathrm{PH}$ & NT & 顾志建等, 1993 \\
\hline 百合科 Liliaceae & 洼瓣花属 Lloydia & L. tibetica Baker ex Oliv. & 四川卧龙 Wolong, Sichuan & & 23 & 12 & $2 \mathrm{x}$ & 3,550 & $\mathrm{PH}$ & NT & 高云东等, 2009 \\
\hline 百合科 Liliaceae & 铁线莲属 Clematis & C. udensis Trautv. \& Mey. & 四川峨眉山 Emei Mt., Sichuan & & 14 & 7 & $2 \mathrm{x}$ & 2,750 & $\mathrm{PH}$ & $\begin{array}{l}\text { EA \& } \\
\text { NAD }\end{array}$ & $\begin{array}{l}\text { 李思锋和常朝阳, } \\
1996\end{array}$ \\
\hline
\end{tabular}


王家坚, 彭智邦, 孙航, 聂泽龙, 孟盈. 青藏高原与横断山被子植物区系演化的细胞地理学特征. 生物多样性, 2017, 25 (2): 218-225.

http://www.biodiversity-science.net/CN/10.17520/biods.2016281

\begin{tabular}{|c|c|c|c|c|c|c|c|c|c|c|c|}
\hline 科名 Families & 属名 Genera & 种名 Species & 采集地点 Location & $\mathrm{n}$ & $2 \mathrm{n}$ & $\mathrm{x}$ & $\begin{array}{l}\text { 倍性 } \\
\text { Ploidy }\end{array}$ & $\begin{array}{l}\text { 海拔 } \\
\text { Altitude } \\
\text { (m) }\end{array}$ & $\begin{array}{l}\text { 生活型 } \\
\text { Life form }\end{array}$ & $\begin{array}{l}\text { 分布型 } \\
\text { Areal-type }\end{array}$ & 参考文献 Reference \\
\hline 百合科 Liliaceae & 铁线莲属 Clematis & C. udensis Trautv. \& Mey. & 云南丽江 Lijiang, Yunnan & & 28 & 7 & $4 \mathrm{x}$ & 3,700 & $\mathrm{PH}$ & $\begin{array}{l}\text { EA \& } \\
\text { NAD }\end{array}$ & $\begin{array}{l}\text { 李思锋和常朝阳, } \\
1996\end{array}$ \\
\hline 百合科 Liliaceae & 铁线莲属 Clematis & C. udensis Trautv. \& Mey. & 云南云龙 Yunlong, Yunnan & & 36 & 18 & $2 \mathrm{x}$ & 2,800 & $\mathrm{PH}$ & NT & 王丽等, 1993 \\
\hline 百合科 Liliaceae & $\begin{array}{l}\text { 扭柄花属 } \\
\text { Streptopus }\end{array}$ & S. simplex D. Don & 云南贡山 Gongshan, Yunnan & & 14 & 7 & $2 \mathrm{x}$ & 3,440 & $\mathrm{PH}$ & TA to TA & 张挺和顾志建, 2005 \\
\hline 百合科 Liliaceae & $\begin{array}{l}\text { 扭柄花属 } \\
\text { Streptopus }\end{array}$ & S. simplex D. Don & $\begin{array}{l}\text { 云南片马、福贡 Pianma, Fugong, } \\
\text { Yunnan }\end{array}$ & & 14 & 7 & $2 \mathrm{x}$ & 3,100 & $\mathrm{PH}$ & TA to TA & 张挺和顾志建, 2005 \\
\hline 百合科 Liliaceae & $\begin{array}{l}\text { 扭柄花属 } \\
\text { Streptopus }\end{array}$ & S. simplex D. Don & 云南香格里拉 Shangri-La, Yunnan & & 16 & 8 & $2 \mathrm{x}$ & 3,600 & $\mathrm{PH}$ & TA to TA & 张挺和顾志建, 2005 \\
\hline 百合科 Liliaceae & $\begin{array}{l}\text { 扭柄花属 } \\
\text { Streptopus }\end{array}$ & S. simplex D. Don & 云南小中甸 Xiaozhongdian, Yunnan & & 16 & 8 & $2 \mathrm{x}$ & 3,500 & $\mathrm{PH}$ & TA to TA & 张挺和顾志建, 2005 \\
\hline 百合科 Liliaceae & $\begin{array}{l}\text { 扭柄花属 } \\
\text { Streptopus }\end{array}$ & S. simplex D. Don & 西藏墨脱 Motuo, Tibet & & 48 & 12 & $4 \mathrm{x}$ & 900 & $\mathrm{~W}$ & $\mathrm{C}$ & $\begin{array}{l}\text { 顾志建和孙先风, } \\
1998\end{array}$ \\
\hline 百合科 Liliaceae & 绵冭儿属 Scilla & S. sinensis (Lour.) Merr. & 云南洱源 Eyuan, Yunnan & & 16 & 8 & $2 \mathrm{x}$ & & $\mathrm{PH}$ & OWT & Ding et al, 1998 \\
\hline 百合科 Liliaceae & $\begin{array}{l}\text { 假百合属 } \\
\text { Notholirion }\end{array}$ & N. bulbuiferum (Lingelsh.) Stearn & 云南中甸 Zhongdian, Yunnan & & 24 & 12 & $2 \mathrm{x}$ & 3,400 & $\mathrm{PH}$ & CA & Yu et al, 1996c \\
\hline 百合科 Liliaceae & $\begin{array}{l}\text { 假百合属 } \\
\text { Notholirion }\end{array}$ & N. bulbuiferum (Lingelsh.) Stearn & 四川马尔康 Maerkang, Sichuan & & 24 & 12 & $2 \mathrm{x}$ & 3,700 & $\mathrm{PH}$ & $\mathrm{CA}$ & 高云东等, 2009 \\
\hline 百合科 Liliaceae & $\begin{array}{l}\text { 假百合属 } \\
\text { Notholirion }\end{array}$ & N. bulbuiferum (Lingelsh.) Stearn & 四川马尔康 Maerkang, Sichuan & & 36 & 12 & $3 \mathrm{x}$ & 4,048 & $\mathrm{PH}$ & $\mathrm{CA}$ & 高云东等, 2009 \\
\hline 百合科 Liliaceae & $\begin{array}{l}\text { 假百合属 } \\
\text { Notholirion }\end{array}$ & N. bulbuiferum (Lingelsh.) Stearn & 四川平武 Pingwu, Sichuan & & 24 & 12 & $2 \mathrm{x}$ & 3,600 & $\mathrm{PH}$ & $\mathrm{CA}$ & 高云东等, 2009 \\
\hline 百合科 Liliaceae & 假百合属 & N. campanulatum Cotton \& Stearn & 云南丽江 Lijiang, Yunnan & & 24 & 12 & $2 \mathrm{x}$ & 3,000 & $\mathrm{PH}$ & EA & 王丽等, 1993 \\
\hline
\end{tabular}


王家坚, 彭智邦, 孙航, 聂泽龙, 孟盈. 青藏高原与横断山被子植物区系演化的细胞地理学特征. 生物多样性, 2017, 25 (2): 218-225.

http://www.biodiversity-science.net/CN/10.17520/biods.2016281

\begin{tabular}{|c|c|c|c|c|c|c|c|c|c|c|c|}
\hline 科名 Families & 属名 Genera & 种名 Species & 采集地点 Location & $\mathrm{n}$ & $2 n$ & $\mathrm{x}$ & $\begin{array}{l}\text { 倍性 } \\
\text { Ploidy }\end{array}$ & $\begin{array}{l}\text { 海拔 } \\
\text { Altitude } \\
\text { (m) }\end{array}$ & $\begin{array}{l}\text { 生活型 } \\
\text { Life form }\end{array}$ & $\begin{array}{l}\text { 分布型 } \\
\text { Areal-type }\end{array}$ & 参考文献 Reference \\
\hline & Notholirion & & & & & & & & & & \\
\hline 百合科 Liliaceae & $\begin{array}{l}\text { 假百合属 } \\
\text { Notholirion }\end{array}$ & N. campanulatum Cotton \& Stearn & 云南宁蒗 Ninglang, Yunnan & & 24 & 12 & $2 \mathrm{x}$ & 3,500 & $\mathrm{PH}$ & $\mathrm{CA}$ & Yu et al, 1996c \\
\hline 百合科 Liliaceae & 吉祥草属 Reineckea & R. carnea (Andr.) Kunth & 四川峨眉山 Emei Mt., Sichuan & & 38 & 19 & $2 \mathrm{x}$ & & $\mathrm{PH}$ & EA & 汤彦承等, 1984 \\
\hline 百合科 Liliaceae & $\begin{array}{l}\text { 大百合属 } \\
\text { Cardiocrinum }\end{array}$ & C. giganteum Makino & 四川峨眉山 Emei Mt., Sichuan & 8 & & 8 & $2 \mathrm{x}$ & & $\mathrm{PH}$ & $\begin{array}{l}\text { EA \& } \\
\text { NAD }\end{array}$ & 汤彦承等, 1984 \\
\hline 百合科 Liliaceae & $\begin{array}{l}\text { 大百合属 } \\
\text { Cardiocrinum }\end{array}$ & C. giganteum Makino & 云南贡山 Gongshan, Yunnan & & 24 & 12 & $2 \mathrm{x}$ & 2,700 & $\mathrm{PH}$ & EA & 谢晓阳等, 1992 \\
\hline 百合科 Liliaceae & 芴属 Allium & A. anisopodium Ledeb. & $\begin{array}{l}\text { 甘肃黄土高原子午岭林区 Ziwu Mt., } \\
\text { Gansu }\end{array}$ & & 22 & 11 & $2 \mathrm{x}$ & 1,400 & $\mathrm{PH}$ & NT & 范小峰等, 2000 \\
\hline 百合科 Liliaceae & 芴属 Allium & A. beesianum W. W. Sm. & 四川雅江 Yajiang, Sichuan & & 16 & 8 & $2 \mathrm{x}$ & 4,401 & $\mathrm{PH}$ & NT & 周春景等, 2012 \\
\hline 百合科 Liliaceae & 芴属 Allium & A. carolinianum DC. & $\begin{array}{l}\text { 青海可可西里, 金乌兰湖 Jinwulan } \\
\text { Lake, Kekexili, Qinghai }\end{array}$ & & 16 & 8 & $2 \mathrm{x}$ & 4,810 & $\mathrm{PH}$ & NT & $\begin{array}{l}\text { 杨永平和武素功, } \\
1993\end{array}$ \\
\hline 百合科 Liliaceae & 苟属 Allium & A. carolinianum Delar. & 青海玛多 Maduo, Qinghai & & 58 & 29 & $2 \mathrm{x}$ & 4,800 & PH & EA & Huang et al, 1996a \\
\hline 百合科 Liliaceae & 苟属 Allium & A. cepa var. proliferum Regel & 四川汶川 Wenchuan, Sichuan & & 17 & $8-9$ & $2 \mathrm{x}$ & 1,655 & PH & NT & 魏先芹等, 2011 \\
\hline 百合科 Liliaceae & 芴属 Allium & A. changduense J. M. Xu & 西藏类乌齐 Leiwuqi, Xizang & & 16 & 8 & $2 \mathrm{x}$ & 4,000 & $\mathrm{PH}$ & NT & 张宇澄等, 2008 \\
\hline 百合科 Liliaceae & 葱属 Allium & A. chienchuanense J. M. Xu & 云南剑川 Jianchuan, Yunnan & & 22 & 11 & $2 \mathrm{x}$ & 2,800 & $\mathrm{PH}$ & NT & Huang et al, 1995 \\
\hline 百合科 Liliaceae & 芴属 Allium & A. chrysanthum Regel & 四川雀儿山 Que’er Mt., Sichuan & & 16 & 8 & $2 \mathrm{x}$ & 4,400 & $\mathrm{PH}$ & NT & 张宇澄等, 2008 \\
\hline 百合科 Liliaceae & 苾属 Allium & A. cyaneum Regel & 四川雀儿山 Que’er Mt., Sichuan & & 48 & 8 & $6 \mathrm{x}$ & 4,400 & $\mathrm{PH}$ & NT & 张宇澄等, 2008 \\
\hline 百合科 Liliaceae & 苟属 Allium & A. cyaneum Regel & 西藏昌都 Changdu, Tibet & & 40 & 8 & $5 \mathrm{x}$ & 3,150 & $\mathrm{PH}$ & NT & 张宇澄等, 2009 \\
\hline 百合科 Liliaceae & 芴属 Allium & A. cyaneum Regel & 四川理塘 Litang, Sichuan & & 16 & 8 & $2 \mathrm{x}$ & 3,892 & $\mathrm{PH}$ & NT & 周春景等, 2012 \\
\hline 百合科 Liliaceae & 苾属 Allium & $\begin{array}{l}\text { A. cyathophorum E. Bureau \& A. } \\
\text { Franchet }\end{array}$ & 西藏察雅 Chaya, Tibet & & 16 & 8 & $2 x$ & 3,780 & $\mathrm{PH}$ & NT & 杨蕾等, 1998 \\
\hline
\end{tabular}


王家坚, 彭智邦, 孙航, 聂泽龙, 孟盈. 青藏高原与横断山被子植物区系演化的细胞地理学特征. 生物多样性, 2017, 25 (2): 218-225.

http://www.biodiversity-science.net/CN/10.17520/biods.2016281

\begin{tabular}{|c|c|c|c|c|c|c|c|c|c|c|c|}
\hline 科名 Families & 属名 Genera & 种名 Species & 采集地点 Location & $\mathrm{n}$ & $2 n$ & $\mathrm{x}$ & $\begin{array}{l}\text { 倍性 } \\
\text { Ploidy }\end{array}$ & $\begin{array}{l}\text { 海拔 } \\
\text { Altitude } \\
\text { (m) }\end{array}$ & $\begin{array}{l}\text { 生活型 } \\
\text { Life form }\end{array}$ & $\begin{array}{l}\text { 分布型 } \\
\text { Areal-type }\end{array}$ & 参考文献 Reference \\
\hline 百合科 Liliaceae & 芴属 Allium & $\begin{array}{l}\text { A. cyathophorum E. Bureau \& A. } \\
\text { Franchet }\end{array}$ & 西藏左贡 Zuogong, Tibet & & 16 & 8 & $2 \mathrm{x}$ & 3,700 & PH & NT & 张宇澄等, 2008 \\
\hline 百合科 Liliaceae & 䓤属 Allium & $\begin{array}{l}\text { A. cyathophorum E. Bureau \& A. } \\
\text { Franchet }\end{array}$ & Zhayab, Tibet & & 16 & 8 & $2 \mathrm{x}$ & 3,780 & $\mathrm{PH}$ & NT & 杨蕾等, 1998 \\
\hline 百合科 Liliaceae & 芴属 Allium & $\begin{array}{l}\text { A. cyathophorum E. Bureau \& A. } \\
\text { Franchet }\end{array}$ & 云南中甸 Zhongdian, Yunnan & & 16 & 8 & $2 \mathrm{x}$ & 3,250 & PH & NT & 杨蕾等, 1998 \\
\hline 百合科 Liliaceae & 芴属 Allium & A. delicatulum Siev. ex Schult. F. & 新疆托里 Tuoli, Xinjiang & & 16 & 8 & $2 \mathrm{x}$ & 1,050 & $\mathrm{PH}$ & NT & $\begin{array}{l}\text { 何兴金和许介眉, } \\
2001\end{array}$ \\
\hline 百合科 Liliaceae & 芴属 Allium & A. eusperma Airy-Shaw & 四川巴塘 Batang, Sichuan & & 16 & 8 & $2 \mathrm{x}$ & 3,950 & $\mathrm{PH}$ & NT & 张宇澄等, 2008 \\
\hline 百合科 Liliaceae & 芴属 Allium & A. eusperma J. M. Xu & 西藏昌都 Changdu, Tibet & & 16 & 8 & $2 \mathrm{x}$ & 3,150 & $\mathrm{PH}$ & NT & 张宇澄等, 2009 \\
\hline 百合科 Liliaceae & 苟属 Allium & A. fasciculatum Rendle & 西藏达孜 Dazi, Tibet & & 20 & 10 & $2 \mathrm{x}$ & 3,700 & $\mathrm{PH}$ & NT & 许介眉等, 1998 \\
\hline 百合科 Liliaceae & 苟属 Allium & A. fasciculatum Rendle & 四川理县 Lixian County, Sichuan & & 20 & 10 & $2 \mathrm{x}$ & 2,300 & $\mathrm{PH}$ & NT & 许介眉等, 1998 \\
\hline 百合科 Liliaceae & 䓤属 Allium & A. fasciculatum Rendle & 四川乡城 Xiangcheng, Sichuan & & 20 & 10 & $2 \mathrm{x}$ & 2,950 & $\mathrm{PH}$ & NT & Huang et al, 1995 \\
\hline 百合科 Liliaceae & 葱属 Allium & A. fasciculatum Rendle & 四川乡城 Xiangcheng, Sichuan & & 20 & 10 & $2 \mathrm{x}$ & 2,800 & PH & NT & 许介眉等, 1998 \\
\hline 百合科 Liliaceae & 䓤属 Allium & A. forrestii Diels & 四川雀儿山 Que’er Mt., Sichuan & & 16 & 8 & $2 \mathrm{x}$ & 4,400 & $\mathrm{PH}$ & NT & 张宇澄等, 2008 \\
\hline 百合科 Liliaceae & 芴属 Allium & A. glomeratum Prokh. & 新疆天山 Tianshan Mt., Xinjiang & & 16 & 8 & $2 \mathrm{x}$ & 2,600 & PH & NT & $\begin{array}{l}\text { 何兴金和许介眉, } \\
2001\end{array}$ \\
\hline 百合科 Liliaceae & 芴属 Allium & A. hookeri Thwaites & 云南大理 Dali, Yunnan & & 33 & 11 & $3 \mathrm{x}$ & 2,050 & $\mathrm{PH}$ & NT & Huang et al, 1995 \\
\hline 百合科 Liliaceae & 芴属 Allium & A. hookeri Thwaites & 云南大理 Dali, Yunnan & & 44 & 11 & $4 \mathrm{x}$ & 2,050 & $\mathrm{PH}$ & NT & Huang et al, 1995 \\
\hline 百合科 Liliaceae & 芴属 Allium & A. hookeri Thwaites & 四川宝兴 Baoxing, Sichuan & & 22 & 11 & $2 \mathrm{x}$ & 1,100 & $\mathrm{PH}$ & NT & $\begin{array}{l}\text { 张绍斌和许介眉, } \\
2002\end{array}$ \\
\hline 百合科 Liliaceae & 䓤属 Allium & A. hookeri Thwaites & 云南中甸 Zhongdian, Yunnan & & 22 & 11 & $2 \mathrm{x}$ & 3,200 & $\mathrm{PH}$ & NT & Huang et al, 1995 \\
\hline 百合科 Liliaceae & 芴属 Allium & A. hookeri var. muliense Airy-Shaw & 云南中甸 Zhongdian, Yunnan & & 22 & 11 & $2 \mathrm{x}$ & 3,200 & $\mathrm{PH}$ & NT & 黄瑞复等, 1996b \\
\hline
\end{tabular}


王家坚, 彭智邦, 孙航, 聂泽龙, 孟盈. 青藏高原与横断山被子植物区系演化的细胞地理学特征. 生物多样性, 2017, 25 (2): 218-225.

http://www.biodiversity-science.net/CN/10.17520/biods.2016281

\begin{tabular}{|c|c|c|c|c|c|c|c|c|c|c|c|}
\hline 科名 Families & 属名 Genera & 种名 Species & 采集地点 Location & $\mathrm{n}$ & $2 n$ & $\mathrm{x}$ & $\begin{array}{l}\text { 倍性 } \\
\text { Ploidy }\end{array}$ & $\begin{array}{l}\text { 海拔 } \\
\text { Altitude } \\
\text { (m) }\end{array}$ & $\begin{array}{l}\text { 生活型 } \\
\text { Life form }\end{array}$ & $\begin{array}{l}\text { 分布型 } \\
\text { Areal-type }\end{array}$ & 参考文献 Reference \\
\hline 百合科 Liliaceae & 苟属 Allium & A. liumhookeri Thwaites & 四川汉源 Hanyuan, Sichuan & & 22 & 11 & $2 \mathrm{x}$ & 1,150 & $\mathrm{PH}$ & NT & 魏先芹等, 2011 \\
\hline 百合科 Liliaceae & 苟属 Allium & A. liumhookeri Thwaites & 云南丽江 Lijiang, Yunnan & & 33 & 11 & $3 \mathrm{x}$ & 2,242 & $\mathrm{PH}$ & NT & 魏先芹等, 2011 \\
\hline 百合科 Liliaceae & 苟属 Allium & A. macranthum Baker & 云南中甸 Zhongdian, Yunnan & & 14 & 7 & $2 \mathrm{x}$ & 3,250 & PH & NT & Huang et al, 1995 \\
\hline 百合科 Liliaceae & 葱属 Allium & A. macranthum Baker & 云南中甸 Zhongdian, Yunnan & & 28 & 7 & $4 \mathrm{x}$ & 3,250 & $\mathrm{PH}$ & NT & Huang et al, 1995 \\
\hline 百合科 Liliaceae & 䓤属 Allium & A. macranthum Baker & 云南中甸 Zhongdian, Yunnan & & 28 & 7 & $4 \mathrm{x}$ & 3,250 & $\mathrm{PH}$ & NT & 黄瑞复等, 1996b \\
\hline 百合科 Liliaceae & 䓤属 Allium & A. macranthum Baker & 西藏芒康 Mangkang, Tibet & & 28 & 7 & $4 \mathrm{x}$ & 3,800 & $\mathrm{PH}$ & NT & 张宇澄等, 2009 \\
\hline 百合科 Liliaceae & 葱属 Allium & A. macrostemon Bunge & $\begin{array}{l}\text { 四川宝兴邓池沟 Dengchigou, } \\
\text { Baoxing, Sichuan }\end{array}$ & & 32 & 8 & $4 \mathrm{x}$ & 1,000 & $\mathrm{PH}$ & NT & $\begin{array}{l}\text { 朱世梅和许介眉, } \\
1999\end{array}$ \\
\hline 百合科 Liliaceae & 芴属 Allium & A. macrostemon Bunge & $\begin{array}{l}\text { 四川都江堰新棺山 Xinguan Mt., } \\
\text { Dujiangyan, Sichuan }\end{array}$ & & 32 & 8 & $4 \mathrm{x}$ & 700 & $\mathrm{PH}$ & NT & $\begin{array}{l}\text { 朱世梅和许介眉, } \\
1999\end{array}$ \\
\hline 百合科 Liliaceae & 苟属 Allium & A. macrostemon Bunge & $\begin{array}{l}\text { 四川汶川玉龙 Yulong, Wenchuan, } \\
\text { Sichuan }\end{array}$ & & 32 & 8 & $4 \mathrm{x}$ & 1,200 & $\mathrm{PH}$ & NT & $\begin{array}{l}\text { 朱世梅和许介眉, } \\
1999\end{array}$ \\
\hline 百合科 Liliaceae & 葱属 Allium & A. macrostemon Bunge & 四川汶川 Wenchuan, Sichuan & & 32 & 8 & $4 \mathrm{x}$ & 2,123 & $\mathrm{PH}$ & NT & 魏先芹等, 2011 \\
\hline 百合科 Liliaceae & 苟属 Allium & A. maowenense J. M. Xu & 四川汶川 Wenchuan, Sichuan & & 16 & 8 & $2 \mathrm{x}$ & 1,425 & PH & NT & 魏先芹等, 2011 \\
\hline 百合科 Liliaceae & 葱属 Allium & A. nanodes Airy Shaw & 四川稻城 Daocheng, Sichuan & & 16 & 8 & $2 \mathrm{x}$ & 4,500 & $\mathrm{PH}$ & NT & 景望春等, 1999 \\
\hline 百合科 Liliaceae & 苟属 Allium & A. omeiense Z. Y. Zhu & 四川峨眉山 Emei Mt., Sichuan & & 22 & 11 & $2 \mathrm{x}$ & 1,400 & $\mathrm{PH}$ & NT & Huang et al, 1995 \\
\hline 百合科 Liliaceae & 苾属 Allium & A. omeiense Z. Y. Zhu & 四川峨眉山 Emei Mt., Sichuan & & 22 & 11 & $2 \mathrm{x}$ & 2,300 & $\mathrm{PH}$ & NT & 张宇澄等, 2008 \\
\hline 百合科 Liliaceae & 芴属 Allium & A. ovalifolium Hand. -Mazz. & 云南中甸 Zhongdian, Yunnan & & 16 & 8 & $2 \mathrm{x}$ & 3,600 & $\mathrm{PH}$ & NT & 景望春等, 1999 \\
\hline 百合科 Liliaceae & 苾属 Allium & A. ovalifolium Hand. -Mazz. & 四川汶川 Wenchuan, Sichuan & & 24 & 8 & $3 x$ & 2,200 & $\mathrm{PH}$ & NT & 景望春等, 1999 \\
\hline 百合科 Liliaceae & 葱属 Allium & A. prattii C. H. Wright & 四川理塘 Litang, Sichuan & & 16 & 8 & $2 \mathrm{x}$ & 4,100 & $\mathrm{PH}$ & NT & 景望春等, 1999 \\
\hline 百合科 Liliaceae & 葱属 Allium & A. prattii C. H. Wright & 四川理县 Lixian County, Sichuan & & 32 & 8 & $4 \mathrm{x}$ & 3,600 & $\mathrm{PH}$ & NT & 景望春等, 1999 \\
\hline 百合科 Liliaceae & 芴属 Allium & $\begin{array}{l}\text { A. prattii C. H. Wright apud Forb. et } \\
\text { Hemsl. }\end{array}$ & 青海玉树 Yushu, Qinghai & & 16 & 8 & $2 \mathrm{x}$ & 3,700 & $\mathrm{PH}$ & NT & 薛春迎等, 2000 \\
\hline
\end{tabular}


王家坚, 彭智邦, 孙航, 聂泽龙, 孟盈. 青藏高原与横断山被子植物区系演化的细胞地理学特征. 生物多样性, 2017, 25 (2): 218-225.

http://www.biodiversity-science.net/CN/10.17520/biods.2016281

\begin{tabular}{|c|c|c|c|c|c|c|c|c|c|c|c|}
\hline 科名 Families & 属名 Genera & 种名 Species & 采集地点 Location & $\mathrm{n}$ & $2 n$ & $\mathrm{x}$ & $\begin{array}{l}\text { 倍性 } \\
\text { Ploidy }\end{array}$ & $\begin{array}{l}\text { 海拔 } \\
\text { Altitude } \\
\text { (m) }\end{array}$ & $\begin{array}{l}\text { 生活型 } \\
\text { Life form }\end{array}$ & $\begin{array}{l}\text { 分布型 } \\
\text { Areal-type }\end{array}$ & 参考文献 Reference \\
\hline 百合科 Liliaceae & 葱属 Allium & $\begin{array}{l}\text { A. prattii C. H. Wright apud Forb. et } \\
\text { Hemsl. }\end{array}$ & 青海玉树 Yushu, Qinghai & & 16 & 8 & $2 \mathrm{x}$ & 3,800 & $\mathrm{PH}$ & NT & 薛春迎等, 2000 \\
\hline 百合科 Liliaceae & 苟属 Allium & A. przewalskianum Regel & 西藏察雅 Chaya, Tibet & & 32 & 8 & $4 \mathrm{x}$ & 3,780 & PH & NT & 杨蕾等, 1998 \\
\hline 百合科 Liliaceae & 葱属 Allium & A. przewalskianum Regel & 四川理县 Lixian County, Sichuan & & 32 & 8 & $4 \mathrm{x}$ & 2,300 & $\mathrm{PH}$ & NT & 杨蕾等, 1998 \\
\hline 百合科 Liliaceae & 䓤属 Allium & A. przewalskianum Regel & Zhayab, Tibet & & 32 & 8 & $4 \mathrm{x}$ & 3,780 & $\mathrm{PH}$ & NT & 杨蕾等, 1998 \\
\hline 百合科 Liliaceae & 䓤属 Allium & A. przewalskianum Regel. & 青海玛沈 Maqin, Qinghai & & 32 & 8 & $4 \mathrm{x}$ & 3,400 & $\mathrm{PH}$ & NT & 薛春迎等, 2000 \\
\hline 百合科 Liliaceae & 芴属 Allium & A. przewalskianum Regel. & 青海囊谦 Nangqian, Qinghai & & 32 & 8 & $4 \mathrm{x}$ & 3,550 & $\mathrm{PH}$ & NT & 薛春迎等, 2000 \\
\hline 百合科 Liliaceae & 苟属 Allium & A. przewalskianum Regel. & 青海囊谦 Nangqian, Qinghai & & 64 & 8 & $8 \mathrm{x}$ & 3,600 & $\mathrm{PH}$ & NT & 薛春迎等, 2000 \\
\hline 百合科 Liliaceae & 芴属 Allium & A. przewalskianum Regel. & 青海玉树 Yushu, Qinghai & & 32 & 8 & $4 \mathrm{x}$ & 3,700 & $\mathrm{PH}$ & NT & 薛春迎等, 2000 \\
\hline 百合科 Liliaceae & 苟属 Allium & A. przewalskianum Regel. & 青海玉树 Yushu, Qinghai & & 32 & 8 & $4 \mathrm{x}$ & 3,600 & $\mathrm{PH}$ & NT & 薛春迎等, 2000 \\
\hline 百合科 Liliaceae & 苟属 Allium & A. przewalskianum Regel. & 青海玉树 Yushu, Qinghai & & 32 & 8 & $4 \mathrm{x}$ & 3,750 & $\mathrm{PH}$ & NT & 薛春迎等, 2000 \\
\hline 百合科 Liliaceae & 芴属 Allium & A. przewalskianum Regel. & 西藏左贡 Zuogong, Tibet & & 32 & 8 & $4 \mathrm{x}$ & 3,600 & $\mathrm{PH}$ & NT & 张宇澄等, 2008 \\
\hline 百合科 Liliaceae & 苾属 Allium & A. przewalskianum Regel. & 西藏八宿 Basu, Tibet & & 32 & 8 & $4 \mathrm{x}$ & 3,750 & PH & NT & 周春景等, 2012 \\
\hline 百合科 Liliaceae & 苟属 Allium & A. przewalskianum Regel. & 四川壤塘 Rangtang, Sichuan & & 16 & 8 & $2 \mathrm{x}$ & 3,800 & PH & NT & 周春景等, 2012 \\
\hline 百合科 Liliaceae & 葱属 Allium & A. ramosum $\mathrm{L}$ & 四川汶川 Wenchuan, Sichuan & & 28 & 7 & $4 \mathrm{x}$ & 2,123 & $\mathrm{PH}$ & NT & 魏先芹等, 2011 \\
\hline 百合科 Liliaceae & 苟属 Allium & A. ramosum $\mathrm{L}$ & 四川小金 Xiaojin, Sichuan & & 32 & 8 & $4 \mathrm{x}$ & 2,382 & $\mathrm{PH}$ & NT & 魏先芹等, 2011 \\
\hline 百合科 Liliaceae & 苾属 Allium & A. rude J. M. Xu & 四川理县 Lixian County, Sichuan & & 32 & 8 & $4 \mathrm{x}$ & 2,700 & $\mathrm{PH}$ & NT & 魏先芹等, 2011 \\
\hline 百合科 Liliaceae & 芴属 Allium & A. rude J. M. Xu & 四川炉霍 Luhuo, Sichuan & & 16 & 8 & $2 \mathrm{x}$ & 3,950 & $\mathrm{PH}$ & NT & 张宇澄等, 2008 \\
\hline 百合科 Liliaceae & 芴属 Allium & A. rude J. M. Xu & 四川理塘 Litang, Sichuan & & 16 & 8 & $2 \mathrm{x}$ & 3,892 & $\mathrm{PH}$ & NT & 周春景等, 2012 \\
\hline 百合科 Liliaceae & 苟属 Allium & A. rude J. M. Xu & 四川雅江 Yajiang, Sichuan & & 16 & 8 & $2 \mathrm{x}$ & 4,401 & $\mathrm{PH}$ & NT & 周春景等, 2012 \\
\hline 百合科 Liliaceae & 苟属 Allium & A. sativum $\mathrm{L}$. & 四川汶川 Wenchuan, Sichuan & & 16 & 8 & $2 \mathrm{x}$ & 1,655 & $\mathrm{PH}$ & NT & 魏先芹等, 2011 \\
\hline 百合科 Liliaceae & 芴属 Allium & A. sikkimense Baker & 四川炉霍 Luhuo, Sichuan & & 32 & 8 & $4 \mathrm{x}$ & 3,950 & $\mathrm{PH}$ & NT & 张宇澄等, 2009 \\
\hline 百合科 Liliaceae & 䓤属 Allium & A. sikkimense Baker & 西藏类乌齐 Leiwuqi, Tibet & & 32 & 8 & $4 \mathrm{x}$ & 3,850 & $\mathrm{PH}$ & NT & 张宇澄等, 2009 \\
\hline
\end{tabular}


王家坚, 彭智邦, 孙航, 聂泽龙, 孟盈. 青藏高原与横断山被子植物区系演化的细胞地理学特征. 生物多样性, 2017, 25 (2): 218-225.

http://www.biodiversity-science.net/CN/10.17520/biods.2016281

\begin{tabular}{|c|c|c|c|c|c|c|c|c|c|c|c|}
\hline 科名 Families & 属名 Genera & 种名 Species & 采集地点 Location & $\mathrm{n}$ & $2 n$ & $\mathrm{x}$ & $\begin{array}{l}\text { 倍性 } \\
\text { Ploidy }\end{array}$ & $\begin{array}{l}\text { 海拔 } \\
\text { Altitude } \\
\text { (m) }\end{array}$ & $\begin{array}{l}\text { 生活型 } \\
\text { Life form }\end{array}$ & $\begin{array}{l}\text { 分布型 } \\
\text { Areal-type }\end{array}$ & 参考文献 Reference \\
\hline 百合科 Liliaceae & 苟属 Allium & A. sikkimense Baker & 西藏左贡 Zuogong, Tibet & & 32 & 8 & $4 \mathrm{x}$ & 3,700 & $\mathrm{PH}$ & NT & 张宇澄等, 2009 \\
\hline 百合科 Liliaceae & 芴属 Allium & A. sikkimense Baker & 四川木里 Muli, Sichuan & & 32 & 8 & $4 \mathrm{x}$ & 4,100 & $\mathrm{PH}$ & NT & 周春景等, 2012 \\
\hline 百合科 Liliaceae & 䓤属 Allium & A. sikkimense Baker & 四川壤塘 Rangtang, Sichuan & & 32 & 8 & $4 \mathrm{x}$ & 3,800 & PH & NT & 周春景等, 2012 \\
\hline 百合科 Liliaceae & 葱属 Allium & A. sikkmense Baker & 西藏达日 Dari, Tibet & & 52 & 13 & $4 \mathrm{x}$ & 3,000 & $\mathrm{PH}$ & NT & 顾志建等, 1993 \\
\hline 百合科 Liliaceae & 芴属 Allium & A. subtilissimum Ledeb. & 四川壤塘 Rangtang, Sichuan & & 16 & 8 & $2 \mathrm{x}$ & 3,800 & $\mathrm{PH}$ & NT & 周春景等, 2012 \\
\hline 百合科 Liliaceae & 芴属 Allium & $\begin{array}{l}\text { A. trifurcatum (Wang \& Tang) J. M. } \\
\mathrm{Xu}\end{array}$ & 云南中甸 Zhongdian, Yunnan & & 16 & 8 & $2 x$ & 3,300 & PH & NT & Huang et al, 1995 \\
\hline 百合科 Liliaceae & 芴属 Allium & A. tuberosum Rottl. ex Spreng. & $\begin{array}{l}\text { 四川汶川玉龙 Yulong, Wenchuan, } \\
\text { Sichuan }\end{array}$ & & 32 & 8 & $4 \mathrm{x}$ & 1,100 & $\mathrm{PH}$ & NT & 杨蕾等, 1998 \\
\hline 百合科 Liliaceae & 䓤属 Allium & A. tuberosum Rottl. ex Spreng. & 四川理县 Lixian County, Sichuan & & 32 & 8 & $4 \mathrm{x}$ & 1,100 & $\mathrm{PH}$ & NT & 杨蕾等, 1998 \\
\hline 百合科 Liliaceae & 䓤属 Allium & A. tuberosum Rottl. ex Spreng. & 四川乡城 Xiangcheng, Sichuan & & 32 & 8 & $4 \mathrm{x}$ & 2,800 & PH & NT & 张宇澄等, 2009 \\
\hline 百合科 Liliaceae & 芴属 Allium & A. tuberosum Rottl. ex Spreng. & 云南保山 Baoshan, Yunnan & & 24 & 8 & $3 x$ & 1,500 & $\mathrm{PH}$ & NT & 黄瑞复等, 1985 \\
\hline 百合科 Liliaceae & 䓤属 Allium & A. tuberosum Rottl. ex Spreng. & 四川理县 Lixian County, Sichuan & & 32 & 8 & $4 \mathrm{x}$ & 1,100 & $\mathrm{PH}$ & NT & 杨蕾等, 1998 \\
\hline 百合科 Liliaceae & 葱属 Allium & A. tuberosum Rottl. ex Spreng. & 四川雅安 Ya’an, Sichuan & & 32 & 16 & $2 \mathrm{x}$ & 400 & PH & NT & 周颂东等, 2007 \\
\hline 百合科 Liliaceae & 䓤属 Allium & A. wallichi Kunth & 云南丽江 Lijiang, Yunnan & & 14 & 7 & $2 \mathrm{x}$ & 3,248 & $\mathrm{PH}$ & NT & 魏先芹等, 2011 \\
\hline 百合科 Liliaceae & 芴属 Allium & A. wallichi Kunth & 云南香格里拉 Shangri-la, Yunnan & & 14 & 7 & $2 \mathrm{x}$ & 3,275 & $\mathrm{PH}$ & NT & 魏先芹等, 2011 \\
\hline 百合科 Liliaceae & 葱属 Allium & A. wallichii Kunth & 云南宾川 Binchuan, Yunnan & & 14 & 7 & $2 \mathrm{x}$ & 2,900 & $\mathrm{PH}$ & NT & Huang et al, 1995 \\
\hline 百合科 Liliaceae & 葱属 Allium & A. wallichii Kunth & 云南保山 Baoshan, Yunnan & & 14 & 7 & $2 \mathrm{x}$ & 3,000 & $\mathrm{PH}$ & NT & 杨世雄等, 2003 \\
\hline 百合科 Liliaceae & 䓤属 Allium & A. wallichii Kunth & 云南香格里拉 Shangri-La, Yunnan & & 14 & 7 & $2 \mathrm{x}$ & 3,380 & $\mathrm{PH}$ & NT & 杨世雄等, 2003 \\
\hline 百合科 Liliaceae & 䓤属 Allium & A. wallichii Kunth & 四川巴塘 Batang, Sichuan & & 21 & 7 & $3 \mathrm{x}$ & 3,900 & $\mathrm{PH}$ & NT & 张宇澄等, 2008 \\
\hline 百合科 Liliaceae & 䓤属 Allium & $\begin{array}{l}\text { A. wallichii var. platyphyllum (Diels) } \\
\text { J. M. Xu }\end{array}$ & 云南中甸 Zhongdian, Yunnan & & 14 & 7 & $2 x$ & 3,300 & PH & NT & Huang et al, 1995 \\
\hline 百合科 Liliaceae & 芴属 Allium & A. xichuanense J. M. Xu & 四川康定 Kangding, Sichuan & & 32 & 8 & $4 \mathrm{x}$ & 1,468 & PH & NT & 魏先芹等, 2011 \\
\hline
\end{tabular}


王家坚, 彭智邦, 孙航, 聂泽龙, 孟盈. 青藏高原与横断山被子植物区系演化的细胞地理学特征. 生物多样性, 2017, 25 (2): 218-225.

http://www.biodiversity-science.net/CN/10.17520/biods.2016281

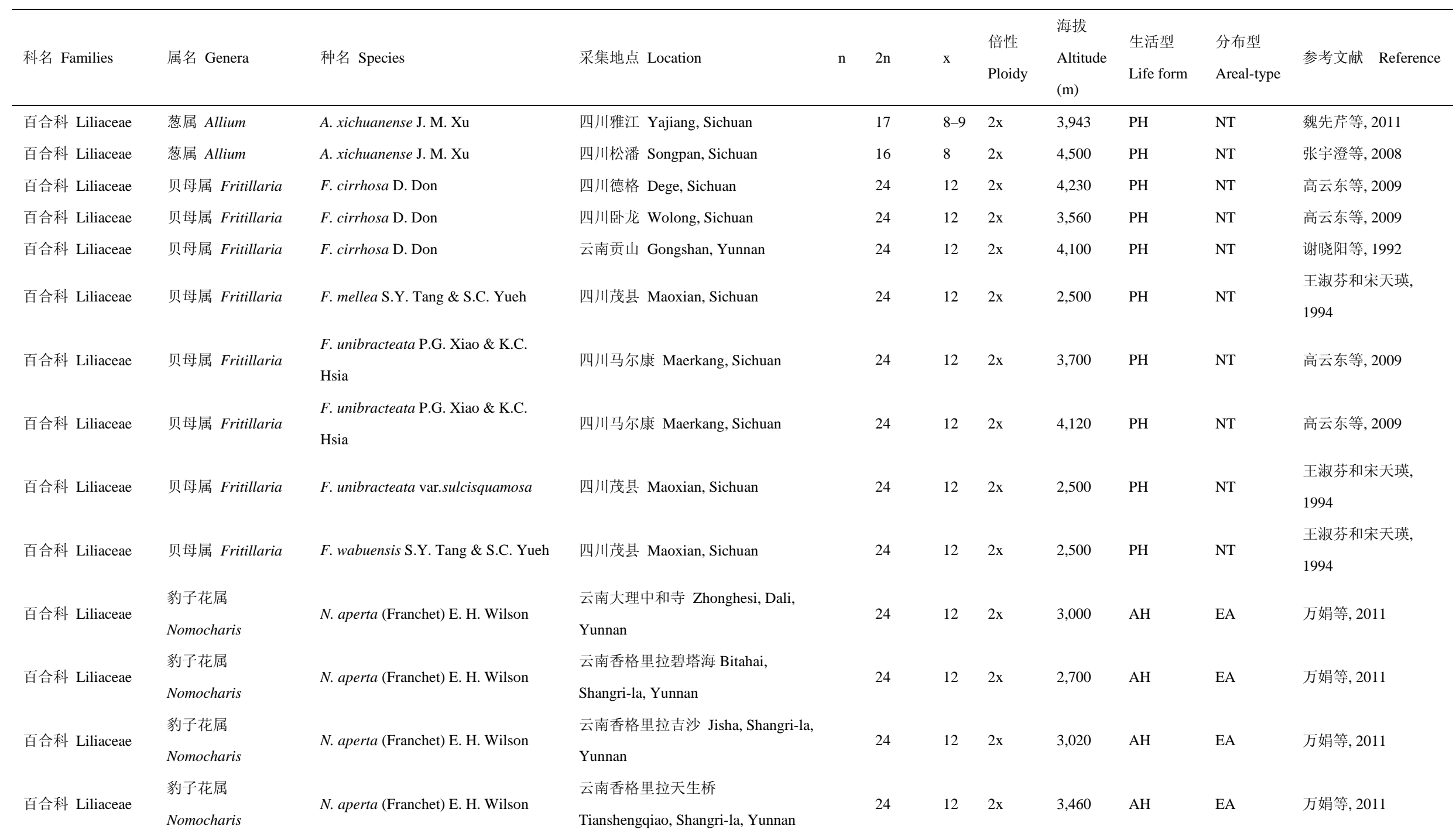


王家坚, 彭智邦, 孙航, 聂泽龙, 孟盈. 青藏高原与横断山被子植物区系演化的细胞地理学特征. 生物多样性, 2017, 25 (2): 218-225.

http://www.biodiversity-science.net/CN/10.17520/biods.2016281

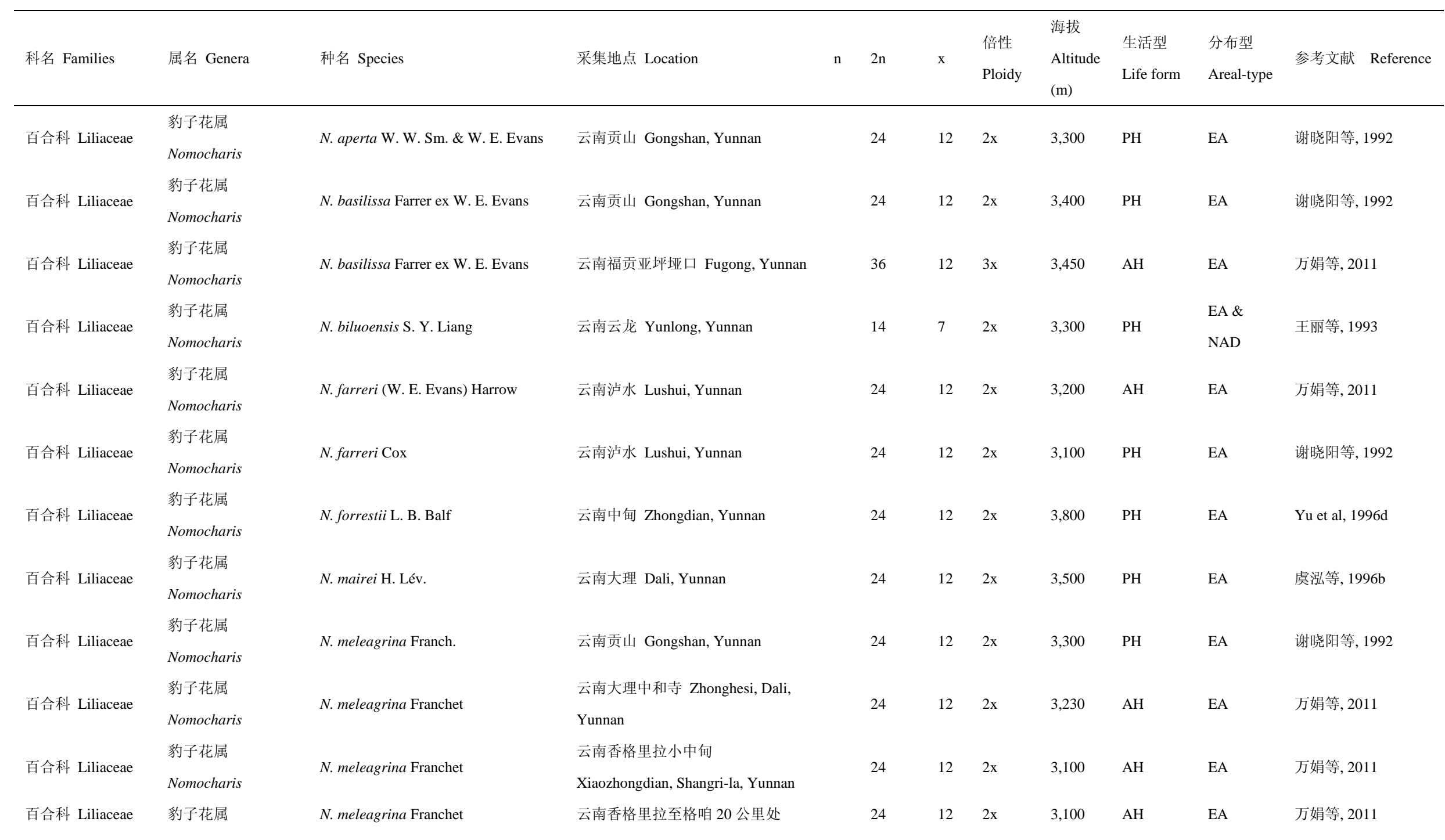


王家坚, 彭智邦, 孙航, 聂泽龙, 孟盈. 青藏高原与横断山被子植物区系演化的细胞地理学特征. 生物多样性, 2017, 25 (2): 218-225.

http://www.biodiversity-science.net/CN/10.17520/biods.2016281

\begin{tabular}{|c|c|c|c|c|c|c|c|c|c|c|c|}
\hline 科名 Families & 属名 Genera & 种名 Species & 采集地点 Location & $\mathrm{n}$ & $2 n$ & $\mathrm{x}$ & $\begin{array}{l}\text { 倍性 } \\
\text { Ploidy }\end{array}$ & $\begin{array}{l}\text { 海拔 } \\
\text { Altitude } \\
\text { (m) }\end{array}$ & $\begin{array}{l}\text { 生活型 } \\
\text { Life form }\end{array}$ & $\begin{array}{l}\text { 分布型 } \\
\text { Areal-type }\end{array}$ & 参考文献 Reference \\
\hline & Nomocharis & & $\begin{array}{l}\text { Between Geza and Shangri-la, } \\
\text { Yunnan }\end{array}$ & & & & & & & & \\
\hline 百合科 Liliaceae & $\begin{array}{l}\text { 豹子花属 } \\
\text { Nomocharis }\end{array}$ & N. pardanthina Franch. & 云南大理 Dali, Yunnan & & 24 & 12 & $2 \mathrm{x}$ & 3,200 & $\mathrm{PH}$ & NT & 王丽等, 1993 \\
\hline 百合科 Liliaceae & $\begin{array}{l}\text { 豹子花属 } \\
\text { Nomocharis }\end{array}$ & N. pardanthina Franch. & 云南贡山 Gongshan, Yunnan & & 24 & 12 & $2 \mathrm{x}$ & 3,000 & $\mathrm{PH}$ & EA & 谢晓阳等, 1992 \\
\hline 百合科 Liliaceae & $\begin{array}{l}\text { 豹子花属 } \\
\text { Nomocharis }\end{array}$ & $\begin{array}{l}\text { N. pardanthina Franch. f. punctulata } \\
\text { Sealy }\end{array}$ & 云南贡山 Gongshan, Yunnan & & 24 & 12 & $2 \mathrm{x}$ & 3,300 & $\mathrm{PH}$ & EA & 谢晓阳等, 1992 \\
\hline 百合科 Liliaceae & $\begin{array}{l}\text { 豹子花属 } \\
\text { Nomocharis }\end{array}$ & N. pardanthina Franchet & 云南福贡亚坪垭口 Fugong, Yunnan & & 23 & 12 & $2 \mathrm{x}$ & 3,550 & $\mathrm{AH}$ & EA & 万娟等, 2011 \\
\hline 百合科 Liliaceae & $\begin{array}{l}\text { 豹子花属 } \\
\text { Nomocharis }\end{array}$ & N. saluenensis Balf. f. & 云南丽江 Lijiang, Yunnan & & 24 & 12 & $2 \mathrm{x}$ & 2,800 & $\mathrm{PH}$ & NT & 王丽等, 1993 \\
\hline 百合科 Liliaceae & $\begin{array}{l}\text { 豹子花属 } \\
\text { Nomocharis }\end{array}$ & N. saluenensis I. B. Balfour & 云南贡山黑普山 Gongshan, Yunnan & & 24 & 12 & $2 \mathrm{x}$ & 3,400 & $\mathrm{AH}$ & EA & 万娟等, 2011 \\
\hline 百合科 Liliaceae & $\begin{array}{l}\text { 豹子花属 } \\
\text { Nomocharis }\end{array}$ & N. saluenensis I. B. Balfour & $\begin{array}{l}\text { 云南香格里拉县格咱乡红山垭口 } \\
\text { Xiangezaxiang, Shangri-la, Yunnan }\end{array}$ & & 24 & 12 & $2 \mathrm{x}$ & 3,800 & $\mathrm{AH}$ & EA & 万娟等, 2011 \\
\hline 百合科 Liliaceae & 百合属 Lilium & L. bakerianum var. rubrum Stearn & 云南大理 Dali, Yunnan & & 36 & 18 & $2 \mathrm{x}$ & 3,200 & $\mathrm{PH}$ & NT & 王丽等, 1993 \\
\hline 百合科 Liliaceae & 百合属 Lilium & L. bakerianum Coll. & $\begin{array}{l}\text { 四川甘孜州泸定县 Luding, Ganzi, } \\
\text { Sichuan }\end{array}$ & & 24 & 12 & $2 \mathrm{x}$ & 1,800 & $\mathrm{PH}$ & NT & 卿秋静, 2011 \\
\hline 百合科 Liliaceae & 百合属 Lilium & L. bakerianum Coll. et Hemsl. & 四川木里 Muli, Sichuan & & 24 & 12 & $2 \mathrm{x}$ & 3,300 & $\mathrm{PH}$ & NT & 万娟等, 2011 \\
\hline 百合科 Liliaceae & 百合属 Lilium & L. bakerianum Coll. et Hemsl. & $\begin{array}{l}\text { 云南香格里拉哈巴雪山 Haba Snow } \\
\text { Mt., Shangri-la, Yunnan }\end{array}$ & & 24 & 12 & $2 \mathrm{x}$ & 2,800 & $\mathrm{PH}$ & NT & 万娟等, 2011 \\
\hline 百合科 Liliaceae & 百合属 Lilium & L. bakerianum Collett et Hemsley var. & 云南丽江 Lijiang, Yunnan & & 24 & 12 & $2 \mathrm{x}$ & 3,100 & $\mathrm{PH}$ & NT & Gao et al, 2011 \\
\hline
\end{tabular}


王家坚, 彭智邦, 孙航, 聂泽龙, 孟盈. 青藏高原与横断山被子植物区系演化的细胞地理学特征. 生物多样性, 2017, 25 (2): 218-225.

http://www.biodiversity-science.net/CN/10.17520/biods.2016281

\begin{tabular}{|c|c|c|c|c|c|c|c|c|c|c|c|}
\hline 科名 Families & 属名 Genera & 种名 Species & 采集地点 Location & $\mathrm{n}$ & $2 n$ & $\mathrm{x}$ & $\begin{array}{l}\text { 倍性 } \\
\text { Ploidy }\end{array}$ & $\begin{array}{l}\text { 海拔 } \\
\text { Altitude } \\
\text { (m) }\end{array}$ & $\begin{array}{l}\text { 生活型 } \\
\text { Life form }\end{array}$ & $\begin{array}{l}\text { 分布型 } \\
\text { Areal-type }\end{array}$ & 参考文献 Reference \\
\hline 百合科 Liliaceae & 百合属 Lilium & $\begin{array}{l}\text { delavayi (Franchet) E. H. Wilson } \\
\text { L. brownii F. E. Brown ex Miellez } \\
\text { var. viridulum Baker }\end{array}$ & 四川汶川 Wenchuan, Sichuan & & 24 & 12 & $2 \mathrm{x}$ & 1,000 & $\mathrm{PH}$ & NT & Gao et al, 2011 \\
\hline 百合科 Liliaceae & 百合属 Lilium & L. brownii F. E. Brown ex Spae & 云南沪水 Lushui, Yunnan & & 24 & 12 & $2 \mathrm{x}$ & 2,000 & PH & NT & 谢晓阳等, 1992 \\
\hline 百合科 Liliaceae & 百合属 Lilium & L. davidii Duch. ex Elwes & 四川卧龙 Wolong, Sichuan & & 24 & 12 & $2 \mathrm{x}$ & 2,560 & $\mathrm{PH}$ & NT & 高云东等, 2009 \\
\hline 百合科 Liliaceae & 百合属 Lilium & L. davidii Duch. ex Elwes & 四川道孚 Daofu, Sichuan & & 24 & 12 & $2 \mathrm{x}$ & 3,100 & $\mathrm{PH}$ & NT & 高云东等, 2009 \\
\hline 百合科 Liliaceae & 百合属 Lilium & L. davidii Duch. ex Elwes & 云南大理 Dali, Yunnan & & 24 & 12 & $2 \mathrm{x}$ & 2,400 & PH & NT & Yu et al, 1996a \\
\hline 百合科 Liliaceae & 百合属 Lilium & L. davidii Duch. ex Elwes & 云南贡山 Gongshan, Yunnan & & 36 & 12 & $3 \mathrm{x}$ & & $\mathrm{PH}$ & NT & $\begin{array}{l}\text { 谢晓阳和武全安, } \\
1993\end{array}$ \\
\hline 百合科 Liliaceae & 百合属 Lilium & L. davidii Duch. ex Elwes & 四川马尔康 Maerkang, Sichuan & & 24 & 12 & $2 \mathrm{x}$ & 2,758 & $\mathrm{PH}$ & NT & 高云东等, 2009 \\
\hline 百合科 Liliaceae & 百合属 Lilium & L. duchartrei Franch. & 四川卧龙 Wolong, Sichuan & & 24 & 12 & $2 \mathrm{x}$ & 2,130 & PH & NT & 高云东等, 2009 \\
\hline 百合科 Liliaceae & 百合属 Lilium & L. duchartrei Franch. & 四川马尔康 Maerkang, Sichuan & & 24 & 12 & $2 \mathrm{x}$ & 2,800 & $\mathrm{PH}$ & NT & 高云东等, 2009 \\
\hline 百合科 Liliaceae & 百合属 Lilium & L. duchartrei Franch. & 云南中甸 Zhongdian, Yunnan & & 24 & 12 & $2 \mathrm{x}$ & 3,200 & $\mathrm{PH}$ & NT & $\begin{array}{l}\text { 黄瑞复和李劲峰, } \\
1996\end{array}$ \\
\hline 百合科 Liliaceae & 百合属 Lilium & L. duchartrei Franch. & $\begin{array}{l}\text { 四川雅安市宝兴县 Baoxing, Ya’an, } \\
\text { Sichuan }\end{array}$ & & 24 & 12 & $2 \mathrm{x}$ & 2,400 & $\mathrm{PH}$ & NT & 卿秋静, 2011 \\
\hline 百合科 Liliaceae & 百合属 Lilium & L. henrici Franch. & 云南大理 Dali, Yunnan & & 36 & 18 & $2 \mathrm{x}$ & 3,200 & $\mathrm{PH}$ & NT & 王丽等, 1993 \\
\hline 百合科 Liliaceae & 百合属 Lilium & L. henricii Franch. & 云南贡山黑普山 Gongshan, Yunnan & & 24 & 12 & $2 \mathrm{x}$ & 3,200 & $\mathrm{PH}$ & NT & 万娟等, 2011 \\
\hline 百合科 Liliaceae & 百合属 Lilium & $\begin{array}{l}\text { L. lankongense (Bur. et Franch.) } \\
\text { Franch. }\end{array}$ & 云南贡山黑娃底 Gongshan, Yunnan & & 24 & 12 & $2 \mathrm{x}$ & 2,000 & $\mathrm{PH}$ & NT & 万娟等, 2011 \\
\hline 百合科 Liliaceae & 百合属 Lilium & $\begin{array}{l}\text { L. lankongense (Bur. et Franch.) } \\
\text { Franch. }\end{array}$ & $\begin{array}{l}\text { 四川乡城热打乡 Redaxiang, } \\
\text { Xiangcheng, Sichuan }\end{array}$ & & 24 & 12 & $2 \mathrm{x}$ & 2,700 & $\mathrm{PH}$ & NT & 万娟等, 2011 \\
\hline 百合科 Liliaceae & 百合属 Lilium & L. lankongense Franchet & 云南丽江 Lijiang, Yunnan & & 24 & 12 & $2 \mathrm{x}$ & 3,350 & $\mathrm{PH}$ & NT & Gao et al, 2011 \\
\hline
\end{tabular}


王家坚, 彭智邦, 孙航, 聂泽龙, 孟盈. 青藏高原与横断山被子植物区系演化的细胞地理学特征. 生物多样性, 2017, 25 (2): 218-225.

http://www.biodiversity-science.net/CN/10.17520/biods.2016281

\begin{tabular}{|c|c|c|c|c|c|c|c|c|c|c|c|}
\hline 科名 Families & 属名 Genera & 种名 Species & 采集地点 Location & $\mathrm{n}$ & $2 \mathrm{n}$ & $\mathrm{x}$ & $\begin{array}{l}\text { 倍性 } \\
\text { Ploidy }\end{array}$ & $\begin{array}{l}\text { 海拔 } \\
\text { Altitude } \\
\text { (m) }\end{array}$ & $\begin{array}{l}\text { 生活型 } \\
\text { Life form }\end{array}$ & $\begin{array}{l}\text { 分布型 } \\
\text { Areal-type }\end{array}$ & 参考文献 Reference \\
\hline 百合科 Liliaceae & 百合属 Lilium & L. lankongense Franchet & 云南香格里拉 Shangri-la, Yunnan & & 24 & 12 & $2 \mathrm{x}$ & 3,400 & PH & NT & Gao et al, 2011 \\
\hline 百合科 Liliaceae & 百合属 Lilium & L. lijiangsense L. J. Peng & 四川会东 Huidong, Sichuan & & 24 & 12 & $2 \mathrm{x}$ & 2,680 & $\mathrm{PH}$ & NT & Gao et al, 2011 \\
\hline 百合科 Liliaceae & 百合属 Lilium & $\begin{array}{l}\text { L. lophophorum (Bur. et Franch.) } \\
\text { Franch. }\end{array}$ & $\begin{array}{l}\text { 西藏昌都达马拉山 Damala Mt., } \\
\text { Changdu, Tibet }\end{array}$ & & 24 & 12 & $2 \mathrm{x}$ & 3,100 & $\mathrm{PH}$ & NT & 万娟等, 2011 \\
\hline 百合科 Liliaceae & 百合属 Lilium & $\begin{array}{l}\text { L. lophophorum (Bur. et Franch.) } \\
\text { Franch. }\end{array}$ & $\begin{array}{l}\text { 西藏昌都类乌齐县 Leiwuqi, } \\
\text { Changdu, Tibet }\end{array}$ & & 24 & 12 & $2 \mathrm{x}$ & 3,200 & $\mathrm{PH}$ & NT & 万娟等, 2011 \\
\hline 百合科 Liliaceae & 百合属 Lilium & $\begin{array}{l}\text { L. lophophorum (Bur. et Franch.) } \\
\text { Franch. }\end{array}$ & $\begin{array}{l}\text { 云南香格里拉大雪山 Snow Mt., } \\
\text { Shangri-la, Yunnan }\end{array}$ & & 24 & 12 & $2 \mathrm{x}$ & 3,700 & $\mathrm{PH}$ & NT & 万娟等, 2011 \\
\hline 百合科 Liliaceae & 百合属 Lilium & $\begin{array}{l}\text { L. lophophorum (Bureau \& Franchet) } \\
\text { Franchet var. lophophorum }\end{array}$ & 四川卧龙 Wolong, Sichuan & & 24 & 12 & $2 \mathrm{x}$ & 3,540 & $\mathrm{PH}$ & NT & Gao et al, 2011 \\
\hline 百合科 Liliaceae & 百合属 Lilium & L. matangense J. M. Xu & 四川马尔康 Maerkang, Sichuan & & 24 & 12 & $2 \mathrm{x}$ & 3,188 & PH & NT & 高云东等, 2009 \\
\hline 百合科 Liliaceae & 百合属 Lilium & L. nanum Klotzsch & 云南德钦 Deqin, Yunnan & & 24 & 12 & $2 \mathrm{x}$ & 4,360 & $\mathrm{PH}$ & NT & Gao et al, 2011 \\
\hline 百合科 Liliaceae & 百合属 Lilium & L. nepalense D. Don & 云南沪水 Lushui, Yunnan & & 24 & 12 & $2 \mathrm{x}$ & 2,700 & $\mathrm{PH}$ & NT & 谢晓阳等, 1992 \\
\hline 百合科 Liliaceae & 百合属 Lilium & L. nepalense D. Don & $\begin{array}{l}\text { 云南大理苍山 Cang Mt., Dali, } \\
\text { Yunnan }\end{array}$ & & 24 & 12 & $2 \mathrm{x}$ & 2,400 & $\mathrm{PH}$ & NT & 李标等, 2004 \\
\hline
\end{tabular}


王家坚, 彭智邦, 孙航, 聂泽龙, 孟盈. 青藏高原与横断山被子植物区系演化的细胞地理学特征. 生物多样性, 2017, 25 (2): 218-225.

http://www.biodiversity-science.net/CN/10.17520/biods.2016281

\begin{tabular}{|c|c|c|c|c|c|c|c|c|c|c|c|}
\hline 科名 Families & 属名 Genera & 种名 Species & 采集地点 Location & $\mathrm{n}$ & $2 \mathrm{n}$ & $\mathrm{x}$ & $\begin{array}{l}\text { 倍性 } \\
\text { Ploidy }\end{array}$ & $\begin{array}{l}\text { 海拔 } \\
\text { Altitude } \\
\text { (m) }\end{array}$ & $\begin{array}{l}\text { 生活型 } \\
\text { Life form }\end{array}$ & $\begin{array}{l}\text { 分布型 } \\
\text { Areal-type }\end{array}$ & 参考文献 Reference \\
\hline 百合科 Liliaceae & 百合属 Lilium & L. primulinum var. burmanicum & 云南沪水 Lushui, Yunnan & & 24 & 12 & $2 \mathrm{x}$ & 2,130 & PH & NT & Gao et al, 2011 \\
\hline 百合科 Liliaceae & 百合属 Lilium & L. regale E. H. Wilson & 四川茂县 Maoxian, Sichuan & & 24 & 12 & $2 \mathrm{x}$ & 1,500 & PH & NT & Gao et al, 2011 \\
\hline 百合科 Liliaceae & 百合属 Lilium & L. regale E. H. Wilson & 四川汶川 Wenchuan, Sichuan & & 24 & 12 & $2 \mathrm{x}$ & 1,250 & PH & NT & Gao et al, 2011 \\
\hline 百合科 Liliaceae & 百合属 Lilium & L. regale $\mathrm{E}$. H. Wilson & 四川茂县 Maoxian, Sichuan & & 24 & 12 & $2 \mathrm{x}$ & 1,648 & PH & NT & 刘华敏等, 2010 \\
\hline 百合科 Liliaceae & 百合属 Lilium & L. regale E. H. Wilson & $\begin{array}{l}\text { 四川汶川县白云顶山 Baiyunding } \\
\text { Mt., Wenchuan, Sichuan }\end{array}$ & & 24 & 12 & $2 \mathrm{x}$ & 1,100 & $\mathrm{PH}$ & NT & 卿秋静, 2011 \\
\hline 百合科 Liliaceae & 百合属 Lilium & L. regale E. H. Wilson & 四川茂县 Maoxian, Sichuan & & 24 & 12 & $2 \mathrm{x}$ & 1,630 & PH & NT & 王红霞等, 2006 \\
\hline 百合科 Liliaceae & 百合属 Lilium & L. regale E. H. Wilson & $\begin{array}{l}\text { 四川汶川县后山 Houshan, } \\
\text { Wenchunan, Sichuan }\end{array}$ & & 24 & 12 & $2 \mathrm{x}$ & 1,460 & $\mathrm{PH}$ & NT & 王红霞等, 2006 \\
\hline 百合科 Liliaceae & 百合属 Lilium & L. regale E. H. Wilson & $\begin{array}{l}\text { 四川汶川县青坡 Qingpo, Wenchuan, } \\
\text { Sichuan } \\
\text { 四川汶川县燕乡水磨沟 }\end{array}$ & & 24 & 12 & $2 \mathrm{x}$ & 1,450 & PH & NT & 王红霞等, 2006 \\
\hline 百合科 Liliaceae & 百合属 Lilium & L. sargentiae E. H. Wilson & 四川都江堰 Dujiangyan, Sichuan & & 24 & 12 & $2 \mathrm{x}$ & 980 & $\mathrm{PH}$ & NT & Gao et al, 2011 \\
\hline 百合科 Liliaceae & 百合属 Lilium & L. sargentiae E. H. Wilson & $\begin{array}{l}\text { 四川峨眉市龙池县 Longchi, Emei, } \\
\text { Sichuan }\end{array}$ & & 24 & 12 & $2 \mathrm{x}$ & 970 & $\mathrm{PH}$ & NT & 卿秋静, 2011 \\
\hline 百合科 Liliaceae & 百合属 Lilium & L. sargentiae E. H. Wilson & $\begin{array}{l}\text { 四川峨眉市罗目镇 Luomu, Emei, } \\
\text { Sichuan }\end{array}$ & & 24 & 12 & $2 \mathrm{x}$ & 550 & PH & NT & 卿秋静, 2011 \\
\hline 百合科 Liliaceae & 百合属 Lilium & L. sargentiae E. H. Wilson & $\begin{array}{l}\text { 四川泸定县磨西镇 Moxi, Luding, } \\
\text { Sichuan }\end{array}$ & & 24 & 12 & $2 \mathrm{x}$ & 1,000 & PH & NT & 卿秋静, 2011 \\
\hline
\end{tabular}


王家坚, 彭智邦, 孙航, 聂泽龙, 孟盈. 青藏高原与横断山被子植物区系演化的细胞地理学特征. 生物多样性, 2017, 25 (2): 218-225.

http://www.biodiversity-science.net/CN/10.17520/biods.2016281

\begin{tabular}{|c|c|c|c|c|c|c|c|c|c|c|c|}
\hline 科名 Families & 属名 Genera & 种名 Species & 采集地点 Location & $\mathrm{n}$ & $2 n$ & $\mathrm{x}$ & $\begin{array}{l}\text { 倍性 } \\
\text { Ploidy }\end{array}$ & $\begin{array}{l}\text { 海拔 } \\
\text { Altitude } \\
\text { (m) }\end{array}$ & $\begin{array}{l}\text { 生活型 } \\
\text { Life form }\end{array}$ & $\begin{array}{l}\text { 分布型 } \\
\text { Areal-type }\end{array}$ & 参考文献 Reference \\
\hline 百合科 Liliaceae & 百合属 Lilium & L. sargentiae E. H. Wilson & $\begin{array}{l}\text { 四川天全喇叭河 Laba River, } \\
\text { Tianquan, Sichuan }\end{array}$ & & 24 & 12 & $2 \mathrm{x}$ & 1,500 & $\mathrm{PH}$ & NT & 卿秋静, 2011 \\
\hline 百合科 Liliaceae & 百合属 Lilium & L. sargentiae E. H. Wilson & $\begin{array}{l}\text { 四川汶川县白云顶山 Baiyunding } \\
\text { Mt., Wenchuan, Sichuan }\end{array}$ & & 24 & 12 & $2 \mathrm{x}$ & 1,000 & $\mathrm{PH}$ & NT & 卿秋静, 2011 \\
\hline 百合科 Liliaceae & 百合属 Lilium & L. sargentiae E. H. Wilson & $\begin{array}{l}\text { 四川雅安市音乐阶梯 Music stairs, } \\
\text { Ya’an, Sichuan }\end{array}$ & & 24 & 12 & $2 \mathrm{x}$ & 700 & $\mathrm{PH}$ & NT & 卿秋静, 2011 \\
\hline 百合科 Liliaceae & 百合属 Lilium & L. sargentiae E. H. Wilson & 四川宝兴县 Baoxing, Sichuan & & 24 & 12 & $2 \mathrm{x}$ & 1,680 & $\mathrm{PH}$ & NT & 吴祝华等, 2007 \\
\hline 百合科 Liliaceae & 百合属 Lilium & L. sempervivoideum H. Léveillé & 四川西昌 Xichang, Sichuan & & 24 & 12 & $2 \mathrm{x}$ & 1,350 & $\mathrm{PH}$ & NT & Gao et al, 2011 \\
\hline 百合科 Liliaceae & 百合属 Lilium & L. souliei (Franch.) Sealy & 云南贡山 Gongshan, Yunnan & & 24 & 12 & $2 \mathrm{x}$ & 3,500 & $\mathrm{PH}$ & NT & 谢晓阳等, 1992 \\
\hline 百合科 Liliaceae & 百合属 Lilium & L. souliei (Franch.) Sealy & $\begin{array}{l}\text { 云南香格里拉格咱红山 Zahong Mt., } \\
\text { Shangri-la, Yunnan }\end{array}$ & & 24 & 12 & $2 \mathrm{x}$ & 3,100 & $\mathrm{PH}$ & NT & 万娟等, 2011 \\
\hline 百合科 Liliaceae & 百合属 Lilium & L. sulphureum Baker apud Hook. f. & 云南保山 Baoshan, Yunnan & & 24 & 12 & $2 \mathrm{x}$ & 1,650 & $\mathrm{PH}$ & NT & 张绍斌等, 2004 \\
\hline 百合科 Liliaceae & 百合属 Lilium & L. sulphureum Baker ex J. D. Hooker & 四川美姑 Meigu, Sichuan & & 24 & 12 & $2 \mathrm{x}$ & 1,400 & $\mathrm{PH}$ & NT & Gao et al, 2011 \\
\hline 百合科 Liliaceae & 百合属 Lilium & L. taliense Franchet & 云南贡山 Gongshan, Yunnan & & 24 & 12 & $2 \mathrm{x}$ & 2,000 & $\mathrm{PH}$ & NT & 谢晓阳等, 1992 \\
\hline 百合科 Liliaceae & 百合属 Lilium & L. taliense Franchet & 云南丽江 Lijiang, Yunnan & & 24 & 12 & $2 \mathrm{x}$ & 3,450 & $\mathrm{PH}$ & NT & Gao et al, 2011 \\
\hline 百合科 Liliaceae & 百合属 Lilium & L. taliense Franchet & 云南香格里拉 Shangri-la, Yunnan & & 24 & 12 & $2 \mathrm{x}$ & 3,020 & PH & NT & Gao et al, 2011 \\
\hline 百合科 Liliaceae & 百合属 Lilium & L. taliense Franchet & 云南香格里拉 Shangri-la, Yunnan & & 24 & 12 & $2 \mathrm{x}$ & 3,400 & $\mathrm{PH}$ & NT & Gao et al, 2011 \\
\hline 百合科 Liliaceae & 百合属 Lilium & L. tigrinum Ker Gawl. & 四川北川 Beichuan, Sichuan & & 36 & 12 & $3 x$ & 1,260 & $\mathrm{PH}$ & NT & 高云东等, 2009 \\
\hline 百合科 Liliaceae & 百合属 Lilium & L. tigrinum Ker Gawl. & 四川松潘 Songpan, Sichuan & & 36 & 12 & $3 \mathrm{x}$ & 2,850 & PH & NT & 高云东等, 2009 \\
\hline 百合科 Liliaceae & 百合属 Lilium & L. wardii Stapf ex Stern & 西藏通麦 Tongmai, Tibet & & 24 & 12 & $2 \mathrm{x}$ & & $\mathrm{PH}$ & NT & 王中轩等, 2013 \\
\hline 百合科 Liliaceae & 百合属 Lilium & L. wenshanense L. J. Peng \& F. X. Li & $\begin{array}{l}\text { 四川江油观雾山 Guanwu Mt., } \\
\text { Jiangyou, Sichuan }\end{array}$ & & 24 & 12 & $2 \mathrm{x}$ & 1,800 & $\mathrm{PH}$ & NT & 万娟等, 2011 \\
\hline 百合科 Liliaceae & 百合属 Lilium & L. xanthellum Wang et Tang & 云南香格里拉东旺乡 & & 24 & 12 & $2 \mathrm{x}$ & 3,200 & $\mathrm{PH}$ & NT & 万娟等, 2011 \\
\hline
\end{tabular}


王家坚, 彭智邦, 孙航, 聂泽龙, 孟盈. 青藏高原与横断山被子植物区系演化的细胞地理学特征. 生物多样性, 2017, 25 (2): 218-225.

http://www.biodiversity-science.net/CN/10.17520/biods.2016281

\begin{tabular}{|c|c|c|c|c|c|c|c|c|c|c|c|}
\hline 科名 Families & 属名 Genera & 种名 Species & 采集地点 Location & $\mathrm{n}$ & $2 n$ & $\mathrm{x}$ & $\begin{array}{l}\text { 倍性 } \\
\text { Ploidy }\end{array}$ & $\begin{array}{l}\text { 海拔 } \\
\text { Altitude } \\
\text { (m) }\end{array}$ & $\begin{array}{l}\text { 生活型 } \\
\text { Life form }\end{array}$ & $\begin{array}{l}\text { 分布型 } \\
\text { Areal-type }\end{array}$ & 参考文献 Reference \\
\hline 百合科 Liliaceae & 百合属 Lilium & L. xanthellum Wang et Tang & $\begin{array}{l}\text { Dongwangxiang, Shangri-la, Yunnan } \\
\text { 云南香格里拉尼西乡亚贡雪山 } \\
\text { Nixixiangyagong snow Mt., } \\
\text { Shangri-la, Yunnan } \\
\text { 云南香格里拉尼西乡亚贡雪山 }\end{array}$ & & 23 & 12 & $2 \mathrm{x}$ & 3,300 & $\mathrm{PH}$ & NT & 万娟等, 2011 \\
\hline 百合科 Liliaceae & 百合属 Lilium & L. xanthellum Wang et Tang & $\begin{array}{l}\text { Nixixiangyagong snow Mt., } \\
\text { Shangri-la, Yunnan }\end{array}$ & & 24 & 12 & $2 \mathrm{x}$ & 3,300 & $\mathrm{PH}$ & NT & 万娟等, 2011 \\
\hline $\begin{array}{l}\text { 败酱科 } \\
\text { Valerianaceae }\end{array}$ & 倾草属 Valeriana & $\begin{array}{l}\text { V. hardwickii subsp. latifolia (Rehd. } \\
\text { \& Wils.) Y. F. Wu }\end{array}$ & 四川宝兴 Baoxing, Sichuan & 12 & & 6 & $4 \mathrm{x}$ & 1,850 & $\mathrm{PH}$ & $\mathrm{C}$ & Hong \& Zhang, 1990 \\
\hline $\begin{array}{l}\text { 报春花科 } \\
\text { Primulaceae }\end{array}$ & $\begin{array}{l}\text { 羽叶点地梅属 } \\
\text { Pomatosace }\end{array}$ & P. filicula Maxim. & 青海玛沈 Maqin, Qinghai & & 20 & 10 & $2 \mathrm{x}$ & & $\mathrm{PH}$ & EC & $\begin{array}{l}\text { 孔宏智和刘建全, } \\
1999\end{array}$ \\
\hline $\begin{array}{l}\text { 报春花科 } \\
\text { Primulaceae }\end{array}$ & $\begin{array}{l}\text { 点地梅属 } \\
\text { Androsace }\end{array}$ & A. bulleyana Forrest & 云南中甸 Zhongdian, Yunnan & & 20 & 10 & $2 \mathrm{x}$ & 3,400 & PH & NT & Nakata et al, 1997 \\
\hline $\begin{array}{l}\text { 报春花科 } \\
\text { Primulaceae }\end{array}$ & $\begin{array}{l}\text { 点地梅属 } \\
\text { Androsace }\end{array}$ & A. mariae Kanitz & $\begin{array}{l}\text { 青海青海湖流域 Qinghai Lake, } \\
\text { Qinghai }\end{array}$ & & 24 & 12 & $2 \mathrm{x}$ & 3,200 & PH & NT & 黄荣福, 2003 \\
\hline $\begin{array}{l}\text { 报春花科 } \\
\text { Primulaceae }\end{array}$ & $\begin{array}{l}\text { 点地梅属 } \\
\text { Androsace }\end{array}$ & A. spinulifera (Franchet) R. Knuth & 云南丽江 Lijiang, Yunnan & & 20 & 10 & $2 \mathrm{x}$ & 3,200 & $\mathrm{PH}$ & NT & Nakata et al, 1997 \\
\hline $\begin{array}{l}\text { 报春花科 } \\
\text { Primulaceae }\end{array}$ & $\begin{array}{l}\text { 点地梅属 } \\
\text { Androsace }\end{array}$ & A. squarrosula Maxim. & $\begin{array}{l}\text { 青海巴颜喀拉山 Bayankala Mt., } \\
\text { Qinghai }\end{array}$ & & 80 & 10 & $8 \mathrm{x}$ & 4,700 & $\mathrm{PH}$ & NT & 黄荣福, 2003 \\
\hline $\begin{array}{l}\text { 报春花科 } \\
\text { Primulaceae }\end{array}$ & $\begin{array}{l}\text { 点地梅属 } \\
\text { Androsace }\end{array}$ & A. squarrosula Maxim. & 青海兴海 Xinghai, Qinghai & & 24 & 12 & $2 \mathrm{x}$ & 3,900 & $\mathrm{PH}$ & NT & 黄荣福, 2003 \\
\hline $\begin{array}{l}\text { 报春花科 } \\
\text { Primulaceae }\end{array}$ & $\begin{array}{l}\text { 点地梅属 } \\
\text { Androsace }\end{array}$ & A. squarrosula Maxim. & 青海兴海 Xinghai, Qinghai & & 40 & 10 & $4 \mathrm{x}$ & 3,900 & $\mathrm{PH}$ & NT & 黄荣福, 2003 \\
\hline
\end{tabular}


王家坚, 彭智邦, 孙航, 聂泽龙, 孟盈. 青藏高原与横断山被子植物区系演化的细胞地理学特征. 生物多样性, 2017, 25 (2): 218-225.

http://www.biodiversity-science.net/CN/10.17520/biods.2016281

\begin{tabular}{|c|c|c|c|c|c|c|c|c|c|c|c|}
\hline 科名 Families & 属名 Genera & 种名 Species & 采集地点 Location & $\mathrm{n}$ & $2 n$ & $\mathrm{x}$ & $\begin{array}{l}\text { 倍性 } \\
\text { Ploidy }\end{array}$ & $\begin{array}{l}\text { 海拔 } \\
\text { Altitude } \\
\text { (m) }\end{array}$ & $\begin{array}{l}\text { 生活型 } \\
\text { Life form }\end{array}$ & $\begin{array}{l}\text { 分布型 } \\
\text { Areal-type }\end{array}$ & 参考文献 Reference \\
\hline $\begin{array}{l}\text { 报春花科 } \\
\text { Primulaceae }\end{array}$ & $\begin{array}{l}\text { 点地梅属 } \\
\text { Androsace }\end{array}$ & A. yargogensis & 青海达坂山 Daban Mt., Qinghai & & 60 & 10 & $6 \mathrm{x}$ & 3,875 & $\mathrm{PH}$ & NT & 黄荣福, 2001 \\
\hline $\begin{array}{l}\text { 报春花科 } \\
\text { Primulaceae }\end{array}$ & $\begin{array}{l}\text { 点地梅属 } \\
\text { Androsace }\end{array}$ & A. yargonensis & $\begin{array}{l}\text { 青海巴颜喀拉山 Bayankala Mt., } \\
\text { Qinghai }\end{array}$ & & 40 & 10 & $4 \mathrm{x}$ & 4,700 & $\mathrm{PH}$ & NT & 黄荣福, 2003 \\
\hline $\begin{array}{l}\text { 报春花科 } \\
\text { Primulaceae }\end{array}$ & $\begin{array}{l}\text { 点地梅属 } \\
\text { Androsace }\end{array}$ & A. yargonensis & 青海达坂山 Daban Mt., Qinghai & & 60 & 10 & $6 \mathrm{x}$ & 3,900 & $\mathrm{PH}$ & NT & 黄荣福, 2003 \\
\hline $\begin{array}{l}\text { 报春花科 } \\
\text { Primulaceae }\end{array}$ & $\begin{array}{l}\text { 点地梅属 } \\
\text { Androsace }\end{array}$ & A. yargonensis & 青海达坂山 Daban Mt., Qinghai & & 60 & 10 & $6 \mathrm{x}$ & 3,900 & $\mathrm{PH}$ & NT & 黄荣福, 2001 \\
\hline $\begin{array}{l}\text { 报春花科 } \\
\text { Primulaceae }\end{array}$ & $\begin{array}{l}\text { 点地梅属 } \\
\text { Androsace }\end{array}$ & A. yargonensis & 青海玛多 Maduo, Qinghai & & 40 & 10 & $4 \mathrm{x}$ & 4,600 & $\mathrm{PH}$ & NT & 黄荣福, 2001 \\
\hline $\begin{array}{l}\text { 报春花科 } \\
\text { Primulaceae }\end{array}$ & $\begin{array}{l}\text { 点地梅属 } \\
\text { Androsace }\end{array}$ & A. yargonensis & $\begin{array}{l}\text { 青海巴颜喀拉山 Bayankala Mt., } \\
\text { Qinghai }\end{array}$ & & 40 & 10 & $4 \mathrm{x}$ & 4,800 & $\mathrm{PH}$ & NT & 黄荣福, 2001 \\
\hline $\begin{array}{l}\text { 报春花科 } \\
\text { Primulaceae }\end{array}$ & $\begin{array}{l}\text { 点地梅属 } \\
\text { Androsace }\end{array}$ & A. zambalensis (Petitm.) Hand. -Mazz. & 青海昌马河 Changma River, Qinghai & & 20 & 10 & $2 \mathrm{x}$ & 4,330 & $\mathrm{PH}$ & NT & 黄荣福, 2003 \\
\hline $\begin{array}{l}\text { 报春花科 } \\
\text { Primulaceae }\end{array}$ & $\begin{array}{l}\text { 点地梅属 } \\
\text { Androsace }\end{array}$ & A. zambalensis (Petitm.) Hand. -Mazz. & 青海兴海 Xinghai, Qinghai & & 20 & 10 & $2 \mathrm{x}$ & 3,900 & $\mathrm{PH}$ & NT & 黄荣福, 2003 \\
\hline $\begin{array}{l}\text { 报春花科 } \\
\text { Primulaceae }\end{array}$ & 报春花属 Primula & P. aurantiaca W.W.Sm. & 云南剑川 Jianchuan, Yunnan & & 22 & 11 & $2 \mathrm{x}$ & 3,100 & $\mathrm{PH}$ & NT & 朱慧芬等, 2001 \\
\hline $\begin{array}{l}\text { 报春花科 } \\
\text { Primulaceae }\end{array}$ & 报春花属 Primula & P. beesiana Forrest & 云南丽江 Lijiang, Yunnan & & 22 & 11 & $2 \mathrm{x}$ & 2,500 & $\mathrm{PH}$ & NT & Nakata et al, 1997 \\
\hline $\begin{array}{l}\text { 报春花科 } \\
\text { Primulaceae }\end{array}$ & 报春花属 Primula & P. beesiana Forrest & 云南丽江 Lijiang, Yunnan & & 22 & 11 & $2 \mathrm{x}$ & 2,800 & $\mathrm{PH}$ & NT & 朱慧芬等, 2001 \\
\hline 报春花科 & 报春花属 Primula & P. bulleyana Forrest & 云南丽江 Lijiang, Yunnan & & 22 & 11 & $2 \mathrm{x}$ & 2,800 & PH & NT & 朱慧芬等, 2001 \\
\hline
\end{tabular}


王家坚, 彭智邦, 孙航, 聂泽龙, 孟盈. 青藏高原与横断山被子植物区系演化的细胞地理学特征. 生物多样性, 2017, 25 (2): 218-225.

http://www.biodiversity-science.net/CN/10.17520/biods.2016281

\begin{tabular}{|c|c|c|c|c|c|c|c|c|c|c|c|}
\hline 科名 Families & 属名 Genera & 种名 Species & 采集地点 Location & $\mathrm{n}$ & $2 n$ & $\mathrm{x}$ & $\begin{array}{l}\text { 倍性 } \\
\text { Ploidy }\end{array}$ & $\begin{array}{l}\text { 海拔 } \\
\text { Altitude } \\
\text { (m) }\end{array}$ & $\begin{array}{l}\text { 生活型 } \\
\text { Life form }\end{array}$ & $\begin{array}{l}\text { 分布型 } \\
\text { Areal-type }\end{array}$ & 参考文献 Reference \\
\hline \multicolumn{12}{|l|}{ Primulaceae } \\
\hline $\begin{array}{l}\text { 报春花科 } \\
\text { Primulaceae }\end{array}$ & 报春花属 Primula & P. capitata subsp. sphaerocephala & 云南德钦 Deqin, Yunnan & & 18 & 9 & $2 \mathrm{x}$ & 4,300 & $\mathrm{PH}$ & NT & 张超等, 2012 \\
\hline $\begin{array}{l}\text { 报春花科 } \\
\text { Primulaceae }\end{array}$ & 报春花属 Primula & P. denticulata ssp. sinodenticulata & 云南丽江 Lijiang, Yunnan & & 22 & 11 & $2 \mathrm{x}$ & 2,350 & $\mathrm{PH}$ & NT & 张超等, 2012 \\
\hline $\begin{array}{l}\text { 报春花科 } \\
\text { Primulaceae }\end{array}$ & 报春花属 Primula & P. forrestii I. B. Balfour & 云南丽江 Lijiang, Yunnan & & 24 & 12 & $2 \mathrm{x}$ & 2,700 & $\mathrm{PH}$ & NT & Nakata et al, 1997 \\
\hline $\begin{array}{l}\text { 报春花科 } \\
\text { Primulaceae }\end{array}$ & 报春花属 Primula & P. malacoides Franch. & 云南大理 Dali, Yunnan & & 18 & 9 & $2 x$ & 1,800 & $\mathrm{PH}$ & NT & 张晓曼等, 2013 \\
\hline $\begin{array}{l}\text { 报春花科 } \\
\text { Primulaceae }\end{array}$ & 报春花属 Primula & P. malacoides Franchet. & 云南中甸 Zhongdian, Yunnan & & 18 & 9 & $2 \mathrm{x}$ & 3,200 & $\mathrm{PH}$ & NT & Nakata et al, 1997 \\
\hline $\begin{array}{l}\text { 报春花科 } \\
\text { Primulaceae }\end{array}$ & 报春花属 Primula & $\begin{array}{l}\text { P. monticola (Hand. -Mazz.) F. H. } \\
\text { Chen \& C. M. Hu }\end{array}$ & 四川汶川 Wenchuan, Sichuan & & 16 & 8 & $2 \mathrm{x}$ & 3,700 & $\mathrm{PH}$ & NT & 朱慧芬等, 2001 \\
\hline $\begin{array}{l}\text { 报春花科 } \\
\text { Primulaceae }\end{array}$ & 报春花属 Primula & P. poissoni Franch. & 云南中甸 Zhongdian, Yunnan & & 22 & 11 & $2 \mathrm{x}$ & 3,300 & $\mathrm{PH}$ & NT & 朱慧芬等, 2001 \\
\hline $\begin{array}{l}\text { 报春花科 } \\
\text { Primulaceae }\end{array}$ & 报春花属 Primula & P. poissoni Franchet. & 云南中甸 Zhongdian, Yunnan & & 22 & 11 & $2 \mathrm{x}$ & 3,300 & $\mathrm{PH}$ & NT & Nakata et al, 1997 \\
\hline $\begin{array}{l}\text { 报春花科 } \\
\text { Primulaceae }\end{array}$ & 报春花属 Primula & P. pseudodenticulata Pax & 云南大理 Dali, Yunnan & & 16 & 8 & $2 \mathrm{x}$ & 2,100 & $\mathrm{PH}$ & NT & 张超等, 2012 \\
\hline $\begin{array}{l}\text { 报春花科 } \\
\text { Primulaceae }\end{array}$ & 报春花属 Primula & P. pulchella Franchet. & 云南丽江 Lijiang, Yunnan & & 16 & 8 & $2 \mathrm{x}$ & 2,800 & $\mathrm{PH}$ & NT & Nakata et al, 1997 \\
\hline $\begin{array}{l}\text { 报春花科 } \\
\text { Primulaceae }\end{array}$ & 报春花属 Primula & P. pulverulenta Duthie & 四川康定 Kangding, Sichuan & & 22 & 11 & $2 \mathrm{x}$ & 2,500 & $\mathrm{PH}$ & NT & 朱慧芬等, 2001 \\
\hline
\end{tabular}


王家坚, 彭智邦, 孙航, 聂泽龙, 孟盈. 青藏高原与横断山被子植物区系演化的细胞地理学特征. 生物多样性, 2017, 25 (2): 218-225.

http://www.biodiversity-science.net/CN/10.17520/biods.2016281

\begin{tabular}{|c|c|c|c|c|c|c|c|c|c|c|c|}
\hline 科名 Families & 属名 Genera & 种名 Species & 采集地点 Location & $\mathrm{n}$ & $2 n$ & $\mathrm{x}$ & $\begin{array}{l}\text { 倍性 } \\
\text { Ploidy }\end{array}$ & $\begin{array}{l}\text { 海拔 } \\
\text { Altitude } \\
\text { (m) }\end{array}$ & $\begin{array}{l}\text { 生活型 } \\
\text { Life form }\end{array}$ & $\begin{array}{l}\text { 分布型 } \\
\text { Areal-type }\end{array}$ & 参考文献 Reference \\
\hline $\begin{array}{l}\text { 报春花科 } \\
\text { Primulaceae }\end{array}$ & 报春花属 Primula & P. secundiflora Franch. & 云南大理 Dali, Yunnan & & 22 & 11 & $2 \mathrm{x}$ & 3,200 & $\mathrm{PH}$ & NT & 张晓曼等, 2007 \\
\hline $\begin{array}{l}\text { 报春花科 } \\
\text { Primulaceae }\end{array}$ & 报春花属 Primula & P. secundiflora Franch. & 云南德钦 Deqin, Yunnan & & 22 & 11 & $2 \mathrm{x}$ & 4,300 & $\mathrm{PH}$ & NT & 朱慧芬等, 2001 \\
\hline $\begin{array}{l}\text { 报春花科 } \\
\text { Primulaceae }\end{array}$ & 报春花属 Primula & P. secundiflora Franchet. & 云南中甸 Zhongdian, Yunnan & & 22 & 11 & $2 \mathrm{x}$ & 3,100 & $\mathrm{PH}$ & NT & Nakata et al, 1997 \\
\hline $\begin{array}{l}\text { 报春花科 } \\
\text { Primulaceae }\end{array}$ & 报春花属 Primula & P. serratifolia Franch. & $\begin{array}{l}\text { 云南大理苍山 Cang Mt., Dali, } \\
\text { Yunnan }\end{array}$ & & 22 & 11 & $2 \mathrm{x}$ & 3,760 & $\mathrm{PH}$ & NT & 张晓曼等, 2007 \\
\hline $\begin{array}{l}\text { 报春花科 } \\
\text { Primulaceae }\end{array}$ & 报春花属 Primula & P. sikkimensis Hook & 云南丽江 Lijiang, Yunnan & & 22 & 11 & $2 \mathrm{x}$ & 3,200 & $\mathrm{PH}$ & NT & 张晓曼等, 2013 \\
\hline $\begin{array}{l}\text { 报春花科 } \\
\text { Primulaceae }\end{array}$ & 报春花属 Primula & P. sikkimensis Hook. & 云南德钦 Deqin, Yunnan & & 20 & 10 & $2 \mathrm{x}$ & 4,300 & $\mathrm{PH}$ & NT & 朱慧芬等, 2001 \\
\hline $\begin{array}{l}\text { 报春花科 } \\
\text { Primulaceae }\end{array}$ & 报春花属 Primula & P. sinensis Sabine ex Lindl. & 四川卧龙 Wolong, Sichuan & & 22 & 11 & $2 \mathrm{x}$ & 2,800 & $\mathrm{PH}$ & NT & 张晓曼等, 2007 \\
\hline $\begin{array}{l}\text { 报春花科 } \\
\text { Primulaceae }\end{array}$ & 报春花属 Primula & P. sinolisteri I. B. Balfour & 云南禄劝 Luquan, Yunnan & & 24 & 12 & $2 \mathrm{x}$ & 2,500 & $\mathrm{PH}$ & NT & Nakata et al, 1997 \\
\hline $\begin{array}{l}\text { 报春花科 } \\
\text { Primulaceae }\end{array}$ & 报春花属 Primula & P. sinolisteri I. B. Balfour & 云南中甸 Zhongdian, Yunnan & & 22 & 11 & $2 \mathrm{x}$ & 3,100 & $\mathrm{PH}$ & NT & Nakata et al, 1997 \\
\hline $\begin{array}{l}\text { 报春花科 } \\
\text { Primulaceae }\end{array}$ & 报春花属 Primula & P. viali Delavay ex Franch. & 云南中甸 Zhongdian, Yunnan & & 22 & 11 & $2 \mathrm{x}$ & 4,050 & $\mathrm{PH}$ & NT & 朱慧芬等, 2001 \\
\hline $\begin{array}{l}\text { 车前科 } \\
\text { Plantaginaceae }\end{array}$ & 车前属 Plantago & P. depressa Willd. & 四川甘孜 Ganzi, Sichuan & & 12 & 6 & $2 \mathrm{x}$ & 3,746 & $\mathrm{AH}$ & $\mathrm{C}$ & 钱敏等, 2015 \\
\hline 车前科 & 车前属 Plantago & P. depressa Willd. & 西藏昌都 Changdu, Tibet & & 12 & 6 & $2 \mathrm{x}$ & 3,199 & $\mathrm{AH}$ & $\mathrm{C}$ & 钱敏等, 2015 \\
\hline
\end{tabular}


王家坚, 彭智邦, 孙航, 聂泽龙, 孟盈. 青藏高原与横断山被子植物区系演化的细胞地理学特征. 生物多样性, 2017, 25 (2): 218-225.

http://www.biodiversity-science.net/CN/10.17520/biods.2016281

\begin{tabular}{|c|c|c|c|c|c|c|c|c|c|c|c|}
\hline 科名 Families & 属名 Genera & 种名 Species & 采集地点 Location & $\mathrm{n}$ & $2 \mathrm{n}$ & $\mathrm{x}$ & $\begin{array}{l}\text { 倍性 } \\
\text { Ploidy }\end{array}$ & $\begin{array}{l}\text { 海拔 } \\
\text { Altitude } \\
\text { (m) }\end{array}$ & $\begin{array}{l}\text { 生活型 } \\
\text { Life form }\end{array}$ & $\begin{array}{l}\text { 分布型 } \\
\text { Areal-type }\end{array}$ & 参考文献 Reference \\
\hline \multicolumn{12}{|l|}{ Plantaginaceae } \\
\hline $\begin{array}{l}\text { 车前科 } \\
\text { Plantaginaceae }\end{array}$ & 车前属 Plantago & P. depressa Willd. & 西藏当雄 Dangxiong, Tibet & & 12 & 6 & $2 \mathrm{x}$ & 4,515 & $\mathrm{AH}$ & C & 钱敏等, 2015 \\
\hline $\begin{array}{l}\text { 车前科 } \\
\text { Plantaginaceae }\end{array}$ & 车前属 Plantago & P. depressa Willd. & $\begin{array}{l}\text { 西藏工布江达 Gongbujiangda, } \\
\text { Gongbu, Tibet }\end{array}$ & & 12 & 6 & $2 \mathrm{x}$ & 4,000 & $\mathrm{AH}$ & C & 钱敏等, 2015 \\
\hline $\begin{array}{l}\text { 车前科 } \\
\text { Plantaginaceae }\end{array}$ & 车前属 Plantago & P. depressa Willd. & 西藏江孜 Jiangzi, Tibet & & 12 & 6 & $2 \mathrm{x}$ & 4,506 & $\mathrm{AH}$ & C & 钱敏等, 2015 \\
\hline $\begin{array}{l}\text { 车前科 } \\
\text { Plantaginaceae }\end{array}$ & 车前属 Plantago & P. depressa Willd. & 西藏拉萨 Lhasa, Tibet & & 12 & 6 & $2 \mathrm{x}$ & 3,650 & $\mathrm{AH}$ & C & 钱敏等, 2015 \\
\hline $\begin{array}{l}\text { 车前科 } \\
\text { Plantaginaceae }\end{array}$ & 车前属 Plantago & P. depressa Willd. & 西藏浪卡子 Langkazi, Tibet & & 12 & 6 & $2 \mathrm{x}$ & 4,761 & $\mathrm{AH}$ & C & 钱敏等, 2015 \\
\hline $\begin{array}{l}\text { 车前科 } \\
\text { Plantaginaceae }\end{array}$ & 车前属 Plantago & P. depressa Willd. & 西藏林芝 Linzhi, Tibet & & 24 & 6 & $4 \mathrm{x}$ & 3,783 & $\mathrm{AH}$ & C & 钱敏等, 2015 \\
\hline $\begin{array}{l}\text { 车前科 } \\
\text { Plantaginaceae }\end{array}$ & 车前属 Plantago & P. depressa Willd. & 西藏林周 Linzhou, Tibet & & 12 & 6 & $2 \mathrm{x}$ & 4,347 & $\mathrm{AH}$ & C & 钱敏等, 2015 \\
\hline $\begin{array}{l}\text { 车前科 } \\
\text { Plantaginaceae }\end{array}$ & 车前属 Plantago & P. depressa Willd. & 西藏聂拉木 Nielamu, Tibet & & 12 & 6 & $2 \mathrm{x}$ & 3,794 & $\mathrm{AH}$ & $\mathrm{C}$ & 钱敏等, 2015 \\
\hline
\end{tabular}


王家坚, 彭智邦, 孙航, 聂泽龙, 孟盈. 青藏高原与横断山被子植物区系演化的细胞地理学特征. 生物多样性, 2017, 25 (2): 218-225.

http://www.biodiversity-science.net/CN/10.17520/biods.2016281

\begin{tabular}{|c|c|c|c|c|c|c|c|c|c|c|c|}
\hline 科名 Families & 属名 Genera & 种名 Species & 采集地点 Location & $\mathrm{n}$ & $2 n$ & $\mathrm{x}$ & $\begin{array}{l}\text { 倍性 } \\
\text { Ploidy }\end{array}$ & $\begin{array}{l}\text { 海拔 } \\
\text { Altitude } \\
\text { (m) }\end{array}$ & $\begin{array}{l}\text { 生活型 } \\
\text { Life form }\end{array}$ & $\begin{array}{l}\text { 分布型 } \\
\text { Areal-type }\end{array}$ & 参考文献 Reference \\
\hline $\begin{array}{l}\text { 车前科 } \\
\text { Plantaginaceae }\end{array}$ & 车前属 Plantago & P. depressa Willd. & 西藏曲水 Qushui, Tibet & & 12 & 6 & $2 \mathrm{x}$ & 3,689 & $\mathrm{AH}$ & $\mathrm{C}$ & 钱敏等, 2015 \\
\hline $\begin{array}{l}\text { 车前科 } \\
\text { Plantaginaceae }\end{array}$ & 车前属 Plantago & P. depressa Willd. & 西藏桑日 Sangri, Tibet & & 12 & 6 & $2 \mathrm{x}$ & 3,590 & $\mathrm{AH}$ & $\mathrm{C}$ & 钱敏等, 2015 \\
\hline $\begin{array}{l}\text { 车前科 } \\
\text { Plantaginaceae }\end{array}$ & 车前属 Plantago & P. depressa Willd. & 四川新龙 Xinlong, Sichuan & & 12 & 6 & $2 \mathrm{x}$ & 3,182 & $\mathrm{AH}$ & C & 钱敏等, 2015 \\
\hline $\begin{array}{l}\text { 车前科 } \\
\text { Plantaginaceae }\end{array}$ & 车前属 Plantago & P. depressa Willd. & 西藏亚东 Yadong, Tibet & & 24 & 6 & $4 \mathrm{x}$ & 3,634 & $\mathrm{AH}$ & $\mathrm{C}$ & 钱敏等, 2015 \\
\hline $\begin{array}{l}\text { 车前科 } \\
\text { Plantaginaceae }\end{array}$ & 车前属 Plantago & P. depressa Willd. & 西藏扎囊 Zhanang, Tibet & & 12 & 6 & $2 \mathrm{x}$ & 3,559 & $\mathrm{AH}$ & $\mathrm{C}$ & 钱敏等, 2015 \\
\hline $\begin{array}{l}\text { 车前科 } \\
\text { Plantaginaceae }\end{array}$ & 车前属 Plantago & P. erosa Wall. & 四川宝兴 Baoxing, Sichuan & 9 & & 9 & $2 \mathrm{x}$ & 2,600 & $\mathrm{~W}$ & NT & Hong \& Zhang, 1990 \\
\hline $\begin{array}{l}\text { 车前科 } \\
\text { Plantaginaceae }\end{array}$ & 车前属 Plantago & P. major L. & 西藏日喀则 Rikeze, Tibet & & 12 & 6 & $2 \mathrm{x}$ & 3,805 & $\mathrm{PH}$ & C & 钱敏等, 2015 \\
\hline $\begin{array}{l}\text { 车前科 } \\
\text { Plantaginaceae }\end{array}$ & 车前属 Plantago & P. major L. & 西藏桑日 Sangri, Tibet & & 12 & 6 & $2 \mathrm{x}$ & 3,590 & PH & $\mathrm{C}$ & 钱敏等, 2015 \\
\hline 唇形科 Lamiaceae & 鼠尾草属 Salvia & S. castanea Diels & 云南丽江 Lijiang, Yunnan & & 16 & 8 & $2 \mathrm{x}$ & 2,900 & $\mathrm{PH}$ & $\mathrm{C}$ & Yang \& Gong, 2004 \\
\hline 唇形科 Lamiaceae & 鼠尾草属 Salvia & S. digitaloides var. digitaloides Diels & 云南中甸 Zhongdian, Yunnan & & 16 & 8 & $2 \mathrm{x}$ & 3,350 & $\mathrm{PH}$ & $\mathrm{C}$ & Yang \& Gong, 2004 \\
\hline 唇形科 Lamiaceae & 鼠尾草属 Salvia & S. flava Forrest ex Diels & 云南中甸 Zhongdian, Yunnan & & 16 & 8 & $2 \mathrm{x}$ & 3,400 & $\mathrm{PH}$ & $\mathrm{C}$ & Yang \& Gong, 2004 \\
\hline 唇形科 Lamiaceae & 鼠尾草属 Salvia & S. przewalskii Maximowicz & 云南丽江 Lijiang, Yunnan & & 32 & 8 & $4 \mathrm{x}$ & 2,800 & $\mathrm{PH}$ & $\mathrm{C}$ & Yang \& Gong, 2004 \\
\hline 唇形科 Lamiaceae & 鼠尾草属 Salvia & S. trijuga Diels & 云南中甸 Zhongdian, Yunnan & & 16 & 8 & $2 \mathrm{x}$ & 3,400 & $\mathrm{PH}$ & $\mathrm{C}$ & Yang \& Gong, 2004 \\
\hline 唇形科 Lamiaceae & 鼠尾草属 Salvia & S. yunnanensis C. H. Wright & 云南洱源 Eyuan, Yunnan & & 16 & 8 & $2 \mathrm{x}$ & 2,100 & $\mathrm{~W}$ & $\mathrm{C}$ & Yang \& Gong, 2004 \\
\hline 唇形科 Lamiaceae & 青兰属 & D. heterophyllum Benth. & 青海果洛 Guoluo, Qinghai & & 24 & 6 & $4 \mathrm{x}$ & 3,700 & $\mathrm{PH}$ & OWT & 顾志建等, 1993 \\
\hline
\end{tabular}


王家坚, 彭智邦, 孙航, 聂泽龙, 孟盈. 青藏高原与横断山被子植物区系演化的细胞地理学特征. 生物多样性, 2017, 25 (2): 218-225.

http://www.biodiversity-science.net/CN/10.17520/biods.2016281

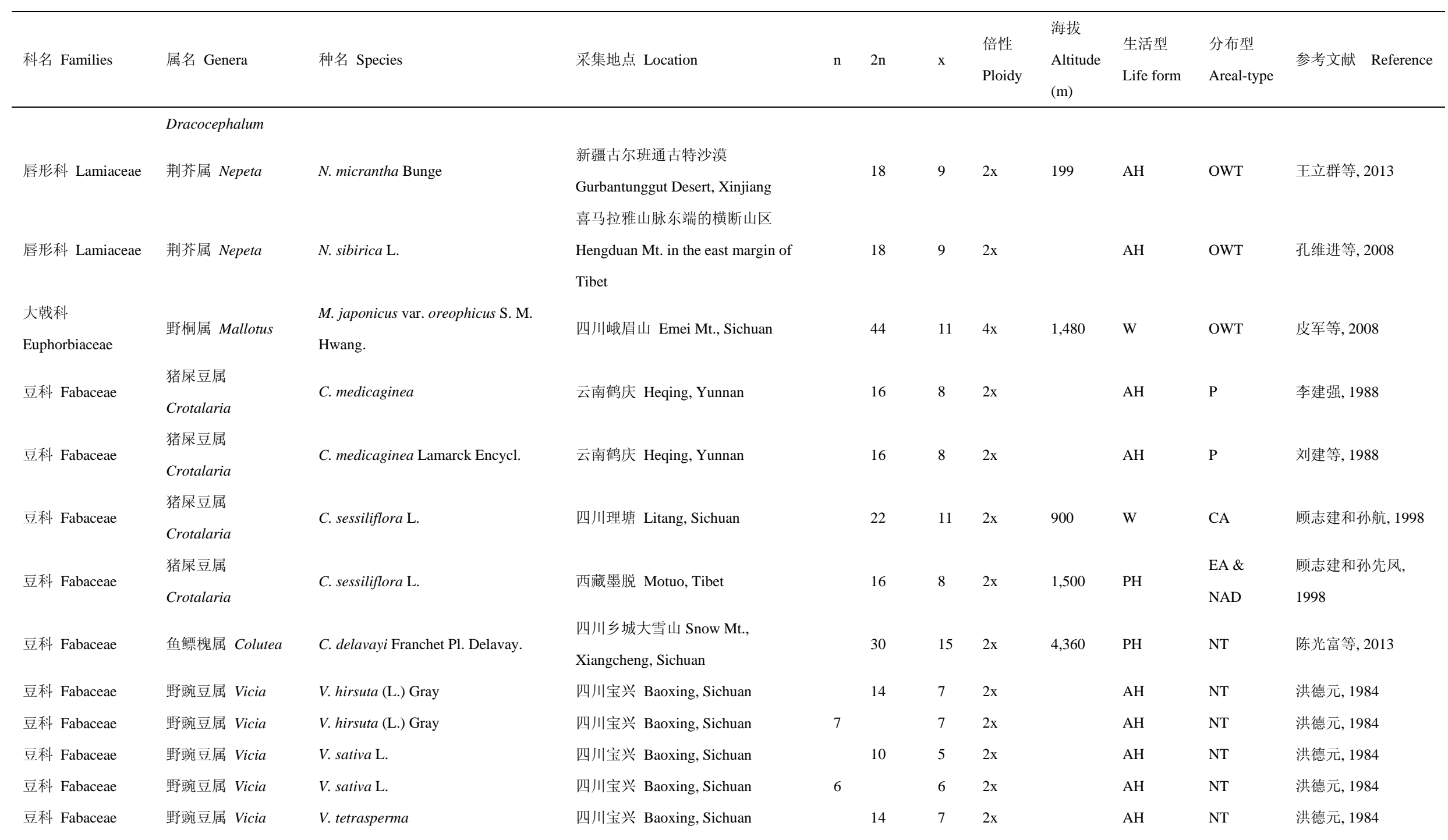


王家坚, 彭智邦, 孙航, 聂泽龙, 孟盈. 青藏高原与横断山被子植物区系演化的细胞地理学特征. 生物多样性, 2017, 25 (2): 218-225.

http://www.biodiversity-science.net/CN/10.17520/biods.2016281

\begin{tabular}{|c|c|c|c|c|c|c|c|c|c|c|c|c|}
\hline 科名 & Families & 属名 Genera & 种名 Species & 采集地点 Location & $\mathrm{n}$ & $2 n$ & $\mathrm{x}$ & $\begin{array}{l}\text { 倍性 } \\
\text { Ploidy }\end{array}$ & $\begin{array}{l}\text { 海拔 } \\
\text { Altitude } \\
\text { (m) }\end{array}$ & $\begin{array}{l}\text { 生活型 } \\
\text { Life form }\end{array}$ & $\begin{array}{l}\text { 分布型 } \\
\text { Areal-type }\end{array}$ & 参考文献 Reference \\
\hline 豆科 & Fabaceae & 野豌豆属 Vicia & V. villosa Roth. & 四川宝兴 Baoxing, Sichuan & & 14 & 7 & $2 \mathrm{x}$ & & $\mathrm{AH}$ & NT & 洪德元, 1984 \\
\hline 豆科 & Fabaceae & 野踠豆属 Vicia & V. villosa Roth. & 四川宝兴 Baoxing, Sichuan & & 12 & 6 & $2 \mathrm{x}$ & & $\mathrm{AH}$ & NT & 洪德元, 1984 \\
\hline 豆科 & Fabaceae & $\begin{array}{l}\text { 山蚂蝗属 } \\
\text { Desmodium }\end{array}$ & D. yunnanense Franch. & 云南鹤庆 Heqing, Yunnan & & 22 & 11 & $2 \mathrm{x}$ & & $\mathrm{W}$ & $\begin{array}{l}\text { EA \& } \\
\text { NAD }\end{array}$ & 崔现举, 1987 \\
\hline 豆科 & Fabaceae & 苜宿属 Medicago & M. edgeworthii Širj. & 云南德钦 Deqin, Yunnan & & 14 & 7 & $2 \mathrm{x}$ & 3,300 & PH & NT & 周自玮等, 2000 \\
\hline 豆科 & Fabaceae & 苜宿属 Medicago & M. lupulina L. & 四川宝兴 Baoxing, Sichuan & 8 & & 8 & $2 \mathrm{x}$ & & PH & OWT & 洪德元, 1984 \\
\hline 豆科 & Fabaceae & 木蓝属 Indigofera & I. amblyantha Craib & 四川茂县 Maoxian, Sichuan & & 16 & 8 & $2 \mathrm{x}$ & & $\mathrm{W}$ & $\mathrm{P}$ & 郑霞等, 2011 \\
\hline 豆科 & Fabaceae & 木蓝属 Indigofera & I. bungeana Walp & 四川泸定 Luding, Sichuan & & 16 & 8 & $2 \mathrm{x}$ & & $\mathrm{W}$ & $\mathrm{P}$ & 郑霞等, 2011 \\
\hline 豆科 & Fabaceae & 木蓝属 Indigofera & I. delavayi Franch & 四川木里 Muli, Sichuan & & 16 & 8 & $2 \mathrm{x}$ & & $\mathrm{W}$ & $\mathrm{P}$ & 郑霞等, 2011 \\
\hline 豆科 & Fabaceae & 木蓝属 Indigofera & I. scabrida Dunn & 四川木里 Muli, Sichuan & & 16 & 8 & $2 \mathrm{x}$ & & $\mathrm{W}$ & $\mathrm{P}$ & 郑霞等, 2011 \\
\hline 豆科 & Fabaceae & 木蓝属 Indigofera & I. silvestrii Pamp & 四川泸定 Luding, Sichuan & & 16 & 8 & $2 \mathrm{x}$ & & $\mathrm{W}$ & $\mathrm{P}$ & 郑霞等, 2011 \\
\hline 豆科 & Fabaceae & 木蓝属 Indigofera & I. szechuensis Craib & 四川茂县 Maoxian, Sichuan & & 16 & 8 & $2 \mathrm{x}$ & & $\mathrm{W}$ & $\mathrm{P}$ & 郑霞等, 2011 \\
\hline 豆科 & Fabaceae & $\begin{array}{l}\text { 米口袋属 } \\
\text { Gueldenstaedtia }\end{array}$ & G. delavayi Franchet. & 云南丽江 Lijiang, Yunnan & & 16 & 8 & $2 \mathrm{x}$ & & $\mathrm{AH}$ & $\mathrm{C}$ & 聂泽龙, 2002 \\
\hline 豆科 & Fabaceae & 锦鸡儿属 Caragana & C. acanthophylla Komarov Trudy & 甘肃桥湾 Qiaowan, Jiuquan, Gansu & & 32 & 16 & $4 \mathrm{x}$ & 1,360 & $\mathrm{PH}$ & $\mathrm{TA}$ & 常朝阳等, 2009 \\
\hline 豆科 & Fabaceae & 锦鸡儿属 Caragana & C. bicolor Komarov Trudy & 四川 Sichuan & & 16 & 8 & $2 \mathrm{x}$ & & $\mathrm{W}$ & $\mathrm{TA}$ & Áskell, 1985 \\
\hline 豆科 & Fabaceae & 锦鸡儿属 Caragana & C. camilli-schneideri Kom. & 甘肃兰州 Lanzhou, Gansu & & 32 & 16 & $4 \mathrm{x}$ & 1,920 & PH & $\mathrm{TA}$ & 常朝阳等, 2009 \\
\hline 豆科 & Fabaceae & 锦鸡儿属 Caragana & C. densa Komarov Trudy & 四川马尔康 Maerkang, Sichuan & & 16 & 8 & $2 \mathrm{x}$ & 2,800 & PH & $\mathrm{TA}$ & 常朝阳等, 2009 \\
\hline 豆科 & Fabaceae & 锦鸡儿属 Caragana & C. erinacea Komarov Trudy & 新疆布克赛尔 Hoboksar, Xinjiang & & 32 & 16 & $4 \mathrm{x}$ & 1,300 & PH & $\mathrm{TA}$ & 常朝阳等, 2009 \\
\hline 豆科 & Fabaceae & 锦鸡儿属 Caragana & C. franchetiana Kom. & 西藏东部 The east margin of Tibet & & 16 & 8 & $2 \mathrm{x}$ & 3,650 & $\mathrm{~W}$ & $\mathrm{TA}$ & 杨杰等, 2007 \\
\hline 豆科 & Fabaceae & 锦鸡儿属 Caragana & C. roborovskyi Komarov Trudy & $\begin{array}{l}\text { 新疆乌鲁木齐妖魔山 Yaomo Mt., } \\
\text { Urumchi, Xinjiang }\end{array}$ & & 16 & 8 & $2 \mathrm{x}$ & 1,000 & $\mathrm{~W}$ & $\mathrm{TA}$ & 常朝阳等, 2009 \\
\hline 豆科 & Fabaceae & 棘豆属 Oxytropis & O. glacialis Benth. ex Bge. & 西藏萨嘎 Saga, Tibet & & 16 & 8 & $2 \mathrm{x}$ & 510 & PH & NT & 王丽等, 1994 \\
\hline
\end{tabular}


王家坚, 彭智邦, 孙航, 聂泽龙, 孟盈. 青藏高原与横断山被子植物区系演化的细胞地理学特征. 生物多样性, 2017, 25 (2): 218-225.

http://www.biodiversity-science.net/CN/10.17520/biods.2016281

\begin{tabular}{|c|c|c|c|c|c|c|c|c|c|c|c|c|}
\hline 科名 & Families & 属名 Genera & 种名 Species & 采集地点 Location & $\mathrm{n}$ & $2 n$ & $\mathrm{x}$ & $\begin{array}{l}\text { 倍性 } \\
\text { Ploidy }\end{array}$ & $\begin{array}{l}\text { 海拔 } \\
\text { Altitude } \\
(\mathrm{m})\end{array}$ & $\begin{array}{l}\text { 生活型 } \\
\text { Life form }\end{array}$ & $\begin{array}{l}\text { 分布型 } \\
\text { Areal-type }\end{array}$ & 参考文献 Reference \\
\hline 豆科 & Fabaceae & 棘豆属 Oxytropis & O. humifusa Kar. et Kir. & 西藏聂荣县 Nierong, Tibet & & 16 & 8 & $2 \mathrm{x}$ & 4,680 & $\mathrm{PH}$ & NT & 刘亚辉等, 2011 \\
\hline 豆科 & Fabaceae & 棘豆属 Oxytropis & O. humifusa Kar. et Kir. & 西藏双湖 Shuanghu, Tibet & & 16 & 8 & $2 \mathrm{x}$ & 4,984 & $\mathrm{PH}$ & NT & 刘亚辉等, 2011 \\
\hline 豆科 & Fabaceae & 棘豆属 Oxytropis & O. kansuensis Bunge & 四川九龙 Jiulong, Sichuan & & 16 & 8 & $2 \mathrm{x}$ & 4,188 & PH & NT & 刘亚辉等, 2011 \\
\hline 豆科 & Fabaceae & 棘豆属 Oxytropis & O. kansuensis Bunge & 四川康定 Kangding, Sichuan & & 16 & 8 & $2 \mathrm{x}$ & 3,800 & $\mathrm{PH}$ & NT & 刘亚辉等, 2011 \\
\hline 豆科 & Fabaceae & 棘豆属 Oxytropis & O. kansuensis Bunge & 四川理塘 Litang, Sichuan & & 16 & 8 & $2 \mathrm{x}$ & 4,022 & $\mathrm{PH}$ & NT & 刘亚辉等, 2011 \\
\hline 豆科 & Fabaceae & 棘豆属 Oxytropis & O. kansuensis Bunge & 四川理塘 Litang, Sichuan & & 16 & 8 & $2 \mathrm{x}$ & 4,078 & $\mathrm{PH}$ & NT & 刘亚辉等, 2011 \\
\hline 豆科 & Fabaceae & 棘豆属 Oxytropis & O. microphyllum (Pall.) DC. & Lazhi, Tibet & & 16 & 8 & $2 \mathrm{x}$ & 3,700 & $\mathrm{PH}$ & NT & 王丽等, 1994 \\
\hline 豆科 & Fabaceae & 棘豆属 Oxytropis & O. microphyllum (Pall.) DC. & 西藏普兰 Pulan, Tibet & & 16 & 8 & $2 \mathrm{x}$ & 4,600 & $\mathrm{PH}$ & NT & 王丽等, 1994 \\
\hline 豆科 & Fabaceae & 棘豆属 Oxytropis & O. ochrocephala Bunge & 西藏聂荣县 Nierong, Tibet & & 16 & 8 & $2 \mathrm{x}$ & 4,680 & $\mathrm{PH}$ & NT & 刘亚辉等, 2011 \\
\hline 豆科 & Fabaceae & 棘豆属 Oxytropis & $\begin{array}{l}\text { O. sericopetala Prain ex C. E. C. } \\
\text { Fisch. }\end{array}$ & 西藏日喀则 Rikeze, Tibet & & 16 & 8 & $2 \mathrm{x}$ & 4,000 & $\mathrm{PH}$ & NT & 王丽等, 1994 \\
\hline 豆科 & Fabaceae & 棘豆属 Oxytropis & O. stracheyana Benth. & 西藏普兰 Pulan, Tibet & & 48 & 8 & $6 \mathrm{x}$ & 4,600 & $\mathrm{PH}$ & NT & 王丽等, 1994 \\
\hline 豆科 & Fabaceae & 棘豆属 Oxytropis & O. stracheyana Bunge & 西藏双湖 Shuanghu, Tibet & & 48 & 8 & $6 \mathrm{x}$ & 4,851 & $\mathrm{PH}$ & NT & 刘亚辉等, 2011 \\
\hline 豆科 & Fabaceae & 棘豆属 Oxytropis & O. tatarica Cambess. ex Bunge & 西藏噶尔县 Gaer, Tibet & & 16 & 8 & $2 \mathrm{x}$ & 4,797 & $\mathrm{PH}$ & NT & 刘亚辉等, 2011 \\
\hline 豆科 & Fabaceae & 棘豆属 Oxytropis & O. tatarica Cambess. ex Bunge & 西藏革吉县 Geji, Tibet & & 16 & 8 & $2 \mathrm{x}$ & 4,823 & $\mathrm{PH}$ & NT & 刘亚辉等, 2011 \\
\hline 豆科 & Fabaceae & 黄耆属 Astragalus & A. acaulis Bakerin J. D. Hooker & 四川 Sichuan & & 16 & 8 & $2 \mathrm{x}$ & & $\mathrm{PH}$ & $\mathrm{C}$ & Áskell, 1985 \\
\hline 豆科 & Fabaceae & 黄耆属 Astragalus & A. ernestii Comber & 四川康定 Kangding, Sichuan & & 16 & 8 & $2 \mathrm{x}$ & & $\mathrm{PH}$ & $\mathrm{C}$ & Áskell, 1985 \\
\hline 豆科 & Fabaceae & 黄耆属 Astragalus & A. hendersonii Baker. & Wudaoliangzhi, Qinghai & & 16 & 8 & $2 \mathrm{x}$ & 4,600 & $\mathrm{~W}$ & $\mathrm{C}$ & 王丽等, 1994 \\
\hline 豆科 & Fabaceae & 黄耆属 Astragalus & A. kialensis N. D. Simpson & 云南 Yunnan & & 16 & 8 & $2 \mathrm{x}$ & & $\mathrm{PH}$ & $\mathrm{C}$ & Áskell, 1985 \\
\hline 豆科 & Fabaceae & 黄耆属 Astragalus & A. oplites Benth. ex Parker & 西藏普兰 Pulan, Tibet & & 16 & 8 & $2 \mathrm{x}$ & 3,700 & $\mathrm{~W}$ & $\mathrm{C}$ & 王丽等, 1994 \\
\hline 豆科 & Fabaceae & 黄耆属 Astragalus & A. pastorius Tsai \& Yu & 四川 Sichuan & & 32 & 8 & $4 \mathrm{x}$ & & $\mathrm{PH}$ & $\mathrm{C}$ & Áskell, 1985 \\
\hline 豆科 & Fabaceae & 黄耆属 Astragalus & A. polycladus Bur. et Franch. & 四川理塘 Litang, Sichuan & & 16 & 8 & $2 x$ & 3,886 & $\mathrm{PH}$ & $\mathrm{C}$ & $\begin{array}{l}\text { 刘玉红和王善敏, } \\
1994\end{array}$ \\
\hline
\end{tabular}


王家坚, 彭智邦, 孙航, 聂泽龙, 孟盈. 青藏高原与横断山被子植物区系演化的细胞地理学特征. 生物多样性, 2017, 25 (2): 218-225.

http://www.biodiversity-science.net/CN/10.17520/biods.2016281

\begin{tabular}{|c|c|c|c|c|c|c|c|c|c|c|c|}
\hline 科名 Families & 属名 Genera & 种名 Species & 采集地点 Location & $\mathrm{n}$ & $2 \mathrm{n}$ & $\mathrm{x}$ & $\begin{array}{l}\text { 倍性 } \\
\text { Ploidy }\end{array}$ & $\begin{array}{l}\text { 海拔 } \\
\text { Altitude } \\
\text { (m) }\end{array}$ & $\begin{array}{l}\text { 生活型 } \\
\text { Life form }\end{array}$ & $\begin{array}{l}\text { 分布型 } \\
\text { Areal-type }\end{array}$ & 参考文献 Reference \\
\hline 豆科 Fabaceae & 黄耆属 Astragalus & A. przewalskii Bunge ex Maximowicz. & 四川 Sichuan & & 16 & 8 & $2 \mathrm{x}$ & & $\mathrm{PH}$ & C & Áskell, 1985 \\
\hline 豆科 Fabaceae & 黄耆属 Astragalus & A. sutchuenensis Franch. & 四川马尔康 Maerkang, Sichuan & & 16 & 8 & $2 \mathrm{x}$ & 2,800 & $\mathrm{PH}$ & C & 黎斌等, 2004 \\
\hline 豆科 Fabaceae & 黄耆属 Astragalus & A. tanguticus Batalin & 四川马尔康 Maerkang, Sichuan & & 16 & 8 & $2 \mathrm{x}$ & 2,800 & $\mathrm{PH}$ & C & 黎斌等, 2004 \\
\hline 豆科 Fabaceae & 高山豆属 Tibetia & T. himalaica (Baker) H. P. TsuiBull & 四川理塘 Litang, Sichuan & & 16 & 8 & $2 \mathrm{x}$ & & PH & EA & 聂泽龙, 2002 \\
\hline 豆科 Fabaceae & 高山豆属 Tibetia & $\begin{array}{l}\text { T. tongolensis (Ulbrich) H. P. } \\
\text { TsuiBull }\end{array}$ & 四川稻城 Daocheng, Sichuan & & 16 & 8 & $2 \mathrm{x}$ & & $\mathrm{PH}$ & EA & Nie et al, 2002 \\
\hline 豆科 Fabaceae & 高山豆属 Tibetia & T. yunnanensis (Diels) H. P. Tsui & 云南中甸 Zhongdian, Yunnan & & 16 & 8 & $2 \mathrm{x}$ & & PH & EA & 聂泽龙, 2002 \\
\hline 豆科 Fabaceae & 高山豆属 Tibetia & $\begin{array}{l}\text { T. yunnanensis (Franchet) H. P. } \\
\text { TsuiBull }\end{array}$ & 云南中甸 Zhongdian, Yunnan & & 16 & 8 & $2 \mathrm{x}$ & & $\mathrm{PH}$ & EA & Nie et al, 2002 \\
\hline 豆科 Fabaceae & 闭英藤属 Mastersia & M. assamica Benth. & 四川理塘 Litang, Sichuan & & 16 & 8 & $2 \mathrm{x}$ & 700 & $\mathrm{w}$ & $\mathrm{TA} \& \mathrm{TA}$ & 顾志建和孙航, 1998 \\
\hline 豆科 Fabaceae & 闭英藤属 Mastersia & M. assamica Benth. & 西藏墨脱 Motuo, Tibet & & 30 & 15 & $2 \mathrm{x}$ & 2,100 & PH & NT & $\begin{array}{l}\text { 顾志建和孙先风, } \\
1998\end{array}$ \\
\hline 豆科 Fabaceae & 百脉根属 Lotus & L. tenuis Waldst. \& Kit. ex Willd. & 四川宝兴 Baoxing, Sichuan & & 12 & 6 & $2 \mathrm{x}$ & & PH & OWT & 洪德元, 1984 \\
\hline $\begin{array}{l}\text { 杜鸠花科 } \\
\text { Ericaceae }\end{array}$ & $\begin{array}{l}\text { 杜鹃花属 } \\
\text { Rhododendron }\end{array}$ & R. leptothrium Balf. f. \& Forrest & 云南维西 Weixi, Yunnan & & 26 & 13 & $2 \mathrm{x}$ & & $\mathrm{PH}$ & NT & Gao, 2002 \\
\hline $\begin{array}{l}\text { 杜鹃花科 } \\
\text { Ericaceae }\end{array}$ & $\begin{array}{l}\text { 杜鹃花属 } \\
\text { Rhododendron }\end{array}$ & R. mackenzianum Forrest & 云南贡山 Gongshan, Yunnan & & 26 & 13 & $2 \mathrm{x}$ & & $\mathrm{PH}$ & NT & Gao, 2002 \\
\hline
\end{tabular}


王家坚, 彭智邦, 孙航, 聂泽龙, 孟盈. 青藏高原与横断山被子植物区系演化的细胞地理学特征. 生物多样性, 2017, 25 (2): 218-225.

http://www.biodiversity-science.net/CN/10.17520/biods.2016281

\begin{tabular}{|c|c|c|c|c|c|c|c|c|c|c|c|}
\hline 科名 Families & 属名 Genera & 种名 Species & 采集地点 Location & $\mathrm{n}$ & $2 \mathrm{n}$ & $\mathrm{x}$ & $\begin{array}{l}\text { 倍性 } \\
\text { Ploidy }\end{array}$ & $\begin{array}{l}\text { 海拔 } \\
\text { Altitude } \\
\text { (m) }\end{array}$ & $\begin{array}{l}\text { 生活型 } \\
\text { Life form }\end{array}$ & $\begin{array}{l}\text { 分布型 } \\
\text { Areal-type }\end{array}$ & 参考文献 Reference \\
\hline $\begin{array}{l}\text { 翡若翠科 } \\
\text { Velloziaceae }\end{array}$ & $\begin{array}{l}\text { 镇苍菊属 } \\
\text { Tricholepis }\end{array}$ & T. furcata DC. & 西藏吉隆 Gyirong, Tibet & & 32 & 16 & $2 \mathrm{x}$ & 2,800 & $\mathrm{PH}$ & $\mathrm{CA}$ & 陈光富等, 2013 \\
\hline $\begin{array}{l}\text { 翡若翠科 } \\
\text { Velloziaceae }\end{array}$ & $\begin{array}{l}\text { 芒苍草属 } \\
\text { Acanthochlamys }\end{array}$ & A. bracteata P. C. Kao & 四川道孚 Daofu, Sichuan & & 38 & 19 & $2 \mathrm{x}$ & 3,100 & PH & EC & 高宝纯等, 1993 \\
\hline 禾本科 Poaceae & 披碱草属 Elymus & E. anthosachnoides (Keng) Á. Löve & 四川巴塘 Batang, Sichuan & & 28 & 14 & $4 \mathrm{x}$ & & PH & NT & Li et al, 1996 \\
\hline 禾本科 Poaceae & 披碱草属 Elymus & E. atratus (Nevski) Handel-Mazzetti & 四川红原 Hongyuan, Sichuan & & 42 & 7 & $6 \mathrm{x}$ & & PH & NT & 刘玉红, 1985 \\
\hline 禾本科 Poaceae & 披碱草属 Elymus & E. atratus (Nevski) Handel-Mazzetti & 四川若尔盖 Ruoergai, Sichuan & & 28 & 14 & $4 \mathrm{x}$ & & PH & NT & 卢宝荣等, 1990 \\
\hline 禾本科 Poaceae & 披碱草属 Elymus & E. cylindricus Honda & 四川甘孜 Ganzi, Sichuan & & 42 & 7 & $6 \mathrm{x}$ & & PH & NT & 刘玉红, 1985 \\
\hline 禾本科 Poaceae & 披碱草属 Elymus & E. cylindricus Honda & 四川红原 Hongyuan, Sichuan & & 42 & 7 & $6 \mathrm{x}$ & & PH & NT & 卢宝荣等, 1990 \\
\hline 禾本科 Poaceae & 披碱草属 Elymus & E. sibiricus Linnaeus & 青海大通 Datong, Qinghai & & 28 & 7 & $4 \mathrm{x}$ & & PH & NT & 张同林等, 2015 \\
\hline 禾本科 Poaceae & 披碱草属 Elymus & E. sibiricus Linnaeus & 四川康定 Kangding, Sichuan & & 28 & 7 & $4 \mathrm{x}$ & & PH & NT & 刘玉红, 1985 \\
\hline 禾本科 Poaceae & 披碱草属 Elymus & E. sibiricus Linnaeus & 四川南坪 Nanping, Sichuan & & 42 & 7 & $6 \mathrm{x}$ & & $\mathrm{PH}$ & NT & 卢宝荣等, 1990 \\
\hline 禾本科 Poaceae & 披碱草属 Elymus & E. sibiricus Linnaeus & 四川若尔盖 Ruoergai, Sichuan & & 28 & 7 & $4 \mathrm{x}$ & & $\mathrm{PH}$ & NT & 卢宝荣等, 1990 \\
\hline 禾本科 Poaceae & 披碱草属 Elymus & E. submuticus Keng ex Keng f. & 四川 Sichuan & & 42 & 7 & $6 \mathrm{x}$ & & PH & NT & $\begin{array}{l}\text { 蔡联炳和冯海生, } \\
1997\end{array}$ \\
\hline 禾本科 Poaceae & 披碱草属 Elymus & $\begin{array}{l}\text { E. tangutorum (Nevski) } \\
\text { Handel-Mazzetti }\end{array}$ & 四川茂汶 Maowen, Sichuan & & 42 & 7 & $6 \mathrm{x}$ & & PH & NT & 卢宝荣等, 1990 \\
\hline
\end{tabular}


王家坚, 彭智邦, 孙航, 聂泽龙, 孟盈. 青藏高原与横断山被子植物区系演化的细胞地理学特征. 生物多样性, 2017, 25 (2): 218-225.

http://www.biodiversity-science.net/CN/10.17520/biods.2016281

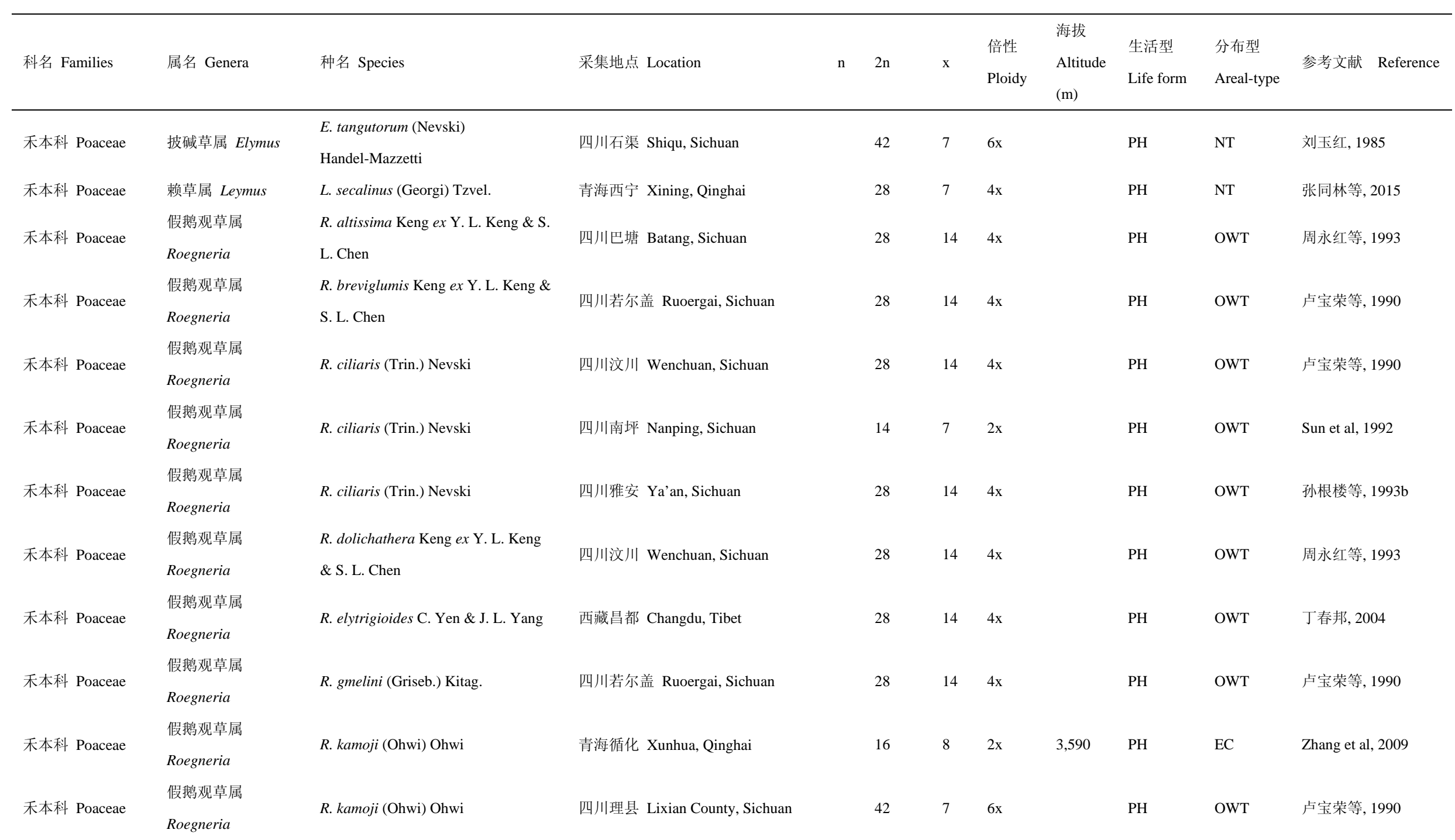


王家坚, 彭智邦, 孙航, 聂泽龙, 孟盈. 青藏高原与横断山被子植物区系演化的细胞地理学特征. 生物多样性, 2017, 25 (2): 218-225.

http://www.biodiversity-science.net/CN/10.17520/biods.2016281

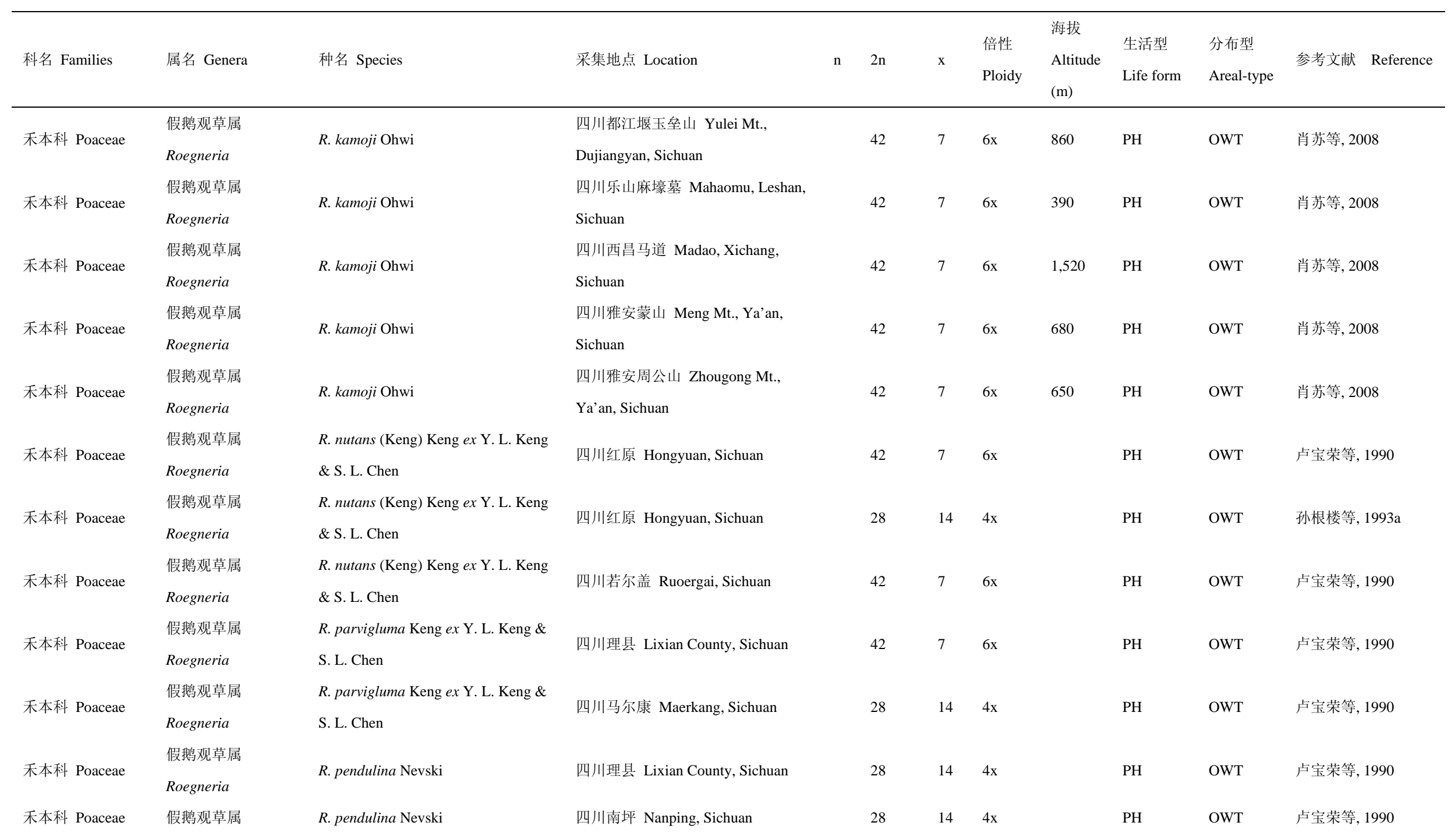


王家坚, 彭智邦, 孙航, 聂泽龙, 孟盈. 青藏高原与横断山被子植物区系演化的细胞地理学特征. 生物多样性, 2017, 25 (2): 218-225.

http://www.biodiversity-science.net/CN/10.17520/biods.2016281

\begin{tabular}{|c|c|c|c|c|c|c|c|c|c|c|c|}
\hline 科名 Families & 属名 Genera & 种名 Species & 采集地点 Location & $\mathrm{n}$ & $2 \mathrm{n}$ & $\mathrm{x}$ & $\begin{array}{l}\text { 倍性 } \\
\text { Ploidy }\end{array}$ & $\begin{array}{l}\text { 海拔 } \\
\text { Altitude } \\
\text { (m) }\end{array}$ & $\begin{array}{l}\text { 生活型 } \\
\text { Life form }\end{array}$ & $\begin{array}{l}\text { 分布型 } \\
\text { Areal-type }\end{array}$ & 参考文献 Reference \\
\hline & Roegneria & & & & & & & & & & \\
\hline 禾本科 Poaceae & $\begin{array}{l}\text { 假鹅观草属 } \\
\text { Roegneria }\end{array}$ & $\begin{array}{l}\text { R. stricta Keng ex Y. L. Keng \& S. L. } \\
\text { Chen }\end{array}$ & 四川茂汶 Maowen, Sichuan & & 28 & 14 & $4 \mathrm{x}$ & & $\mathrm{PH}$ & OWT & 卢宝荣等, 1990 \\
\hline 禾本科 Poaceae & $\begin{array}{l}\text { 假鹅观草属 } \\
\text { Roegneria }\end{array}$ & R. tibetica Á. Löve & 西藏安多 Anduo, Tibet & & 24 & 7 & $4 \mathrm{x}$ & & $\mathrm{PH}$ & OWT & 张同林等, 2015 \\
\hline 禾本科 Poaceae & 钩毛草属 Kelloggia & K. laxiflora (Keng) S. L. Chen & 西藏类乌齐 Leiwuqi, Tibet & & 16 & 8 & $2 \mathrm{x}$ & 4,780 & PH & EC & Zhang et al, 2009 \\
\hline 禾本科 Poaceae & 钩毛草属 Kelloggia & K. melanthera (Keng) S.L.Chen & 四川若尔盖 Ruoergai, Sichuan & & 42 & 7 & $6 \mathrm{x}$ & & PH & CA & 周永红, 1994 \\
\hline 禾本科 Poaceae & 钩毛草属 Kelloggia & $\begin{array}{l}\text { K. thoroldiana (Oliv.) J. L. Yang, Yen } \\
\text { et Baum }\end{array}$ & $\begin{array}{l}\text { 青海三江源地区唐古拉乡 } \\
\text { Tanggulaxiang, Sanjiangyuan, } \\
\text { Qinghai }\end{array}$ & & 42 & 7 & $2 \mathrm{x}$ & 3,500 & $\mathrm{PH}$ & CA & 李淑娟等, 2010 \\
\hline $\begin{array}{l}\text { 胡桃科 } \\
\text { Juglandaceae }\end{array}$ & 胡桃属 Juglans & J. sigillata Dode & 云南淒濞 Yangbi, Yunnan & & 32 & 16 & $2 \mathrm{x}$ & & $\mathrm{w}$ & NT & 穆英林等, 1990 \\
\hline $\begin{array}{l}\text { 葫芦科 } \\
\text { Cucurbitaceae }\end{array}$ & $\begin{array}{l}\text { 绞股蓝属 } \\
\text { Gynostemma }\end{array}$ & $\begin{array}{l}\text { G. longipes C. Y. Wu ex C. Y. Wu \& } \\
\text { S. K. Chen }\end{array}$ & 云南丽江 Lijiang, Yunnan & & 44 & 11 & $4 \mathrm{x}$ & & $\mathrm{PH}$ & TA & 高信芬等, 1995 \\
\hline $\begin{array}{l}\text { 葫芦科 } \\
\text { Cucurbitaceae }\end{array}$ & 赤唿属 Thladiantha & T. davidi Franch. & 四川彭县 Pengxian County, Sichuan & & 18 & 9 & $2 \mathrm{x}$ & 1,230 & $\mathrm{~W}$ & TA to TA & 李建强等, 1993 \\
\hline 葫芦科 & 赤睗属 Thladiantha & T. dentata Cogn. & 四川南川 Nanchuan, Sichuan & & 18 & 9 & $2 \mathrm{x}$ & 1,650 & $\mathrm{w}$ & TA to TA & 李建强等, 1993 \\
\hline
\end{tabular}


王家坚, 彭智邦, 孙航, 聂泽龙, 孟盈. 青藏高原与横断山被子植物区系演化的细胞地理学特征. 生物多样性, 2017, 25 (2): 218-225.

http://www.biodiversity-science.net/CN/10.17520/biods.2016281

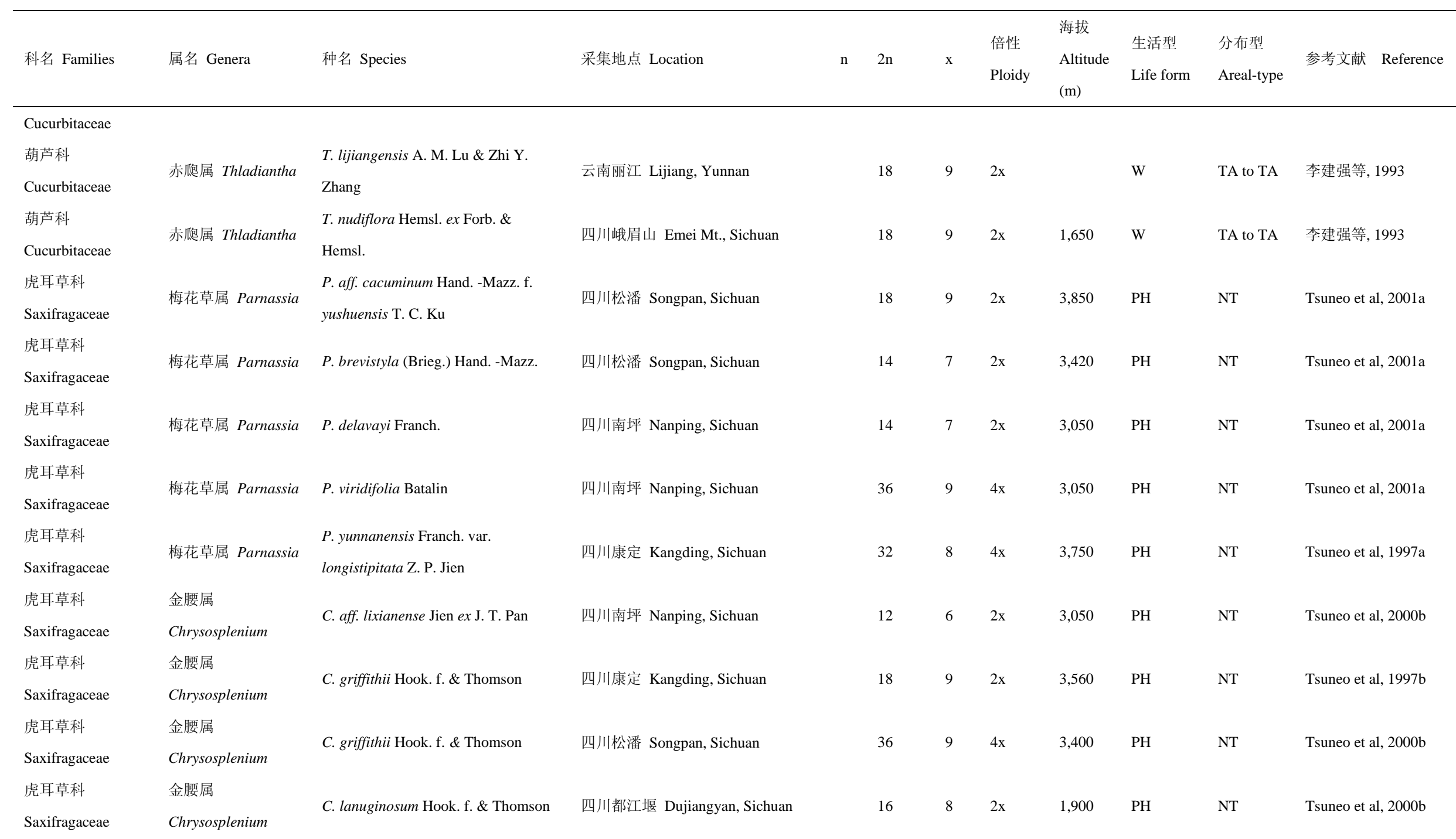


王家坚, 彭智邦, 孙航, 聂泽龙, 孟盈. 青藏高原与横断山被子植物区系演化的细胞地理学特征. 生物多样性, 2017, 25 (2): 218-225.

http://www.biodiversity-science.net/CN/10.17520/biods.2016281

\begin{tabular}{|c|c|c|c|c|c|c|c|c|c|c|c|}
\hline 科名 Families & 属名 Genera & 种名 Species & 采集地点 Location & $\mathrm{n}$ & $2 \mathrm{n}$ & $\mathrm{x}$ & $\begin{array}{l}\text { 倍性 } \\
\text { Ploidy }\end{array}$ & $\begin{array}{l}\text { 海拔 } \\
\text { Altitude } \\
\text { (m) }\end{array}$ & $\begin{array}{l}\text { 生活型 } \\
\text { Life form }\end{array}$ & $\begin{array}{l}\text { 分布型 } \\
\text { Areal-type }\end{array}$ & 参考文献 Reference \\
\hline $\begin{array}{l}\text { 虎耳草科 } \\
\text { Saxifragaceae }\end{array}$ & $\begin{array}{l}\text { 金腰属 } \\
\text { Chrysosplenium }\end{array}$ & $\begin{array}{l}\text { C. pillosum Maxim. var. valdipilosum } \\
\text { Ohwi }\end{array}$ & 四川松潘 Songpan, Sichuan & & 36 & 9 & $4 \mathrm{x}$ & 3,400 & PH & NT & Tsuneo et al, 2000b \\
\hline $\begin{array}{l}\text { 虎耳草科 } \\
\text { Saxifragaceae }\end{array}$ & $\begin{array}{l}\text { 金腰属 } \\
\text { Chrysosplenium }\end{array}$ & C. qinlingense Jien ex J. T. Pan & 四川南坪 Nanping, Sichuan & & 52 & 13 & $4 \mathrm{x}$ & 3,050 & PH & NT & Tsuneo et al, 2000b \\
\hline $\begin{array}{l}\text { 虎耳草科 } \\
\text { Saxifragaceae }\end{array}$ & 虎耳草属 Saxifraga & S. aculeate Balf. f. & 四川康定 Kangding, Sichuan & & 28 & 7 & $4 \mathrm{x}$ & 2,400 & $\mathrm{PH}$ & NT & Tsuneo et al, 1998 \\
\hline $\begin{array}{l}\text { 虎耳草科 } \\
\text { Saxifragaceae }\end{array}$ & 虎耳草属 Saxifraga & S. aurantiana Franch. & 四川松潘 Songpan, Sichuan & & 16 & 8 & $2 \mathrm{x}$ & & $\mathrm{PH}$ & NT & Tsuneo et al, 2001b \\
\hline $\begin{array}{l}\text { 虎耳草科 } \\
\text { Saxifragaceae }\end{array}$ & 虎耳草属 Saxifraga & S. cardiophylla Franch. & 四川康定 Kangding, Sichuan & & 32 & 8 & $4 \mathrm{x}$ & 3,620 & $\mathrm{PH}$ & NT & Tsuneo et al, 1998 \\
\hline $\begin{array}{l}\text { 虎耳草科 } \\
\text { Saxifragaceae }\end{array}$ & 虎耳草属 Saxifraga & S. heleonastes Harry Sm. & 四川松潘 Songpan, Sichuan & & 16 & 8 & $2 \mathrm{x}$ & 3,350 & $\mathrm{PH}$ & NT & Tsuneo et al, 2001b \\
\hline $\begin{array}{l}\text { 虎耳草科 } \\
\text { Saxifragaceae }\end{array}$ & 虎耳草属 Saxifraga & S. hirculus L. & 四川松潘 Songpan, Sichuan & & 32 & 8 & $4 \mathrm{x}$ & 3,850 & $\mathrm{PH}$ & NT & Tsuneo et al, 2001b \\
\hline $\begin{array}{l}\text { 虎耳草科 } \\
\text { Saxifragaceae }\end{array}$ & 虎耳草属 Saxifraga & S. melanocentra Franch. & 四川松潘 Songpan, Sichuan & & 22,23 & 11 & $2 \mathrm{x}$ & 3,850 & PH & NT & Tsuneo et al, 2001b \\
\hline 虎耳草科 & 虎耳草属 Saxifraga & S. montana Harry Sm. & 四川康定 Kangding, Sichuan & & 32 & 8 & $4 \mathrm{x}$ & 3,540 & $\mathrm{PH}$ & NT & Tsuneo et al, 1998 \\
\hline
\end{tabular}


王家坚, 彭智邦, 孙航, 聂泽龙, 孟盈. 青藏高原与横断山被子植物区系演化的细胞地理学特征. 生物多样性, 2017, 25 (2): 218-225.

http://www.biodiversity-science.net/CN/10.17520/biods.2016281

\begin{tabular}{|c|c|c|c|c|c|c|c|c|c|c|c|}
\hline 科名 Families & 属名 Genera & 种名 Species & 采集地点 Location & $\mathrm{n}$ & $2 n$ & $\mathrm{x}$ & $\begin{array}{l}\text { 倍性 } \\
\text { Ploidy }\end{array}$ & $\begin{array}{l}\text { 海拔 } \\
\text { Altitude } \\
\text { (m) }\end{array}$ & $\begin{array}{l}\text { 生活型 } \\
\text { Life form }\end{array}$ & $\begin{array}{l}\text { 分布型 } \\
\text { Areal-type }\end{array}$ & 参考文献 Reference \\
\hline \multicolumn{12}{|l|}{ Saxifragaceae } \\
\hline $\begin{array}{l}\text { 虎耳草科 } \\
\text { Saxifragaceae }\end{array}$ & 虎耳草属 Saxifraga & S. tibetica A. Losinsk. & $\begin{array}{l}\text { 青海可可西里乌兰乌拉湖 } \\
\text { Wulanwula Lake, Kekexili, Qinghai }\end{array}$ & & 16 & 8 & $2 \mathrm{x}$ & 5,000 & $\mathrm{PH}$ & NT & $\begin{array}{l}\text { 杨永平和武素功, } \\
1993\end{array}$ \\
\hline $\begin{array}{l}\text { 虎耳草科 } \\
\text { Saxifragaceae }\end{array}$ & 鬼灯檠属 Rodgersia & R. aesculifolia Batalin & 四川阿坝 Aba, Sichuan & & 30 & 15 & $2 \mathrm{x}$ & & PH & OWT & Tsuneo et al, 2000a \\
\hline $\begin{array}{l}\text { 虎耳草科 } \\
\text { Saxifragaceae }\end{array}$ & 鬼灯檠属 Rodgersia & R. pinnata Franch. & 云南丽江 Lijiang, Yunnan & & 60 & 15 & $4 \mathrm{x}$ & & $\mathrm{PH}$ & OWT & Akiyama et al, 1990 \\
\hline $\begin{array}{l}\text { 虎耳草科 } \\
\text { Saxifragaceae }\end{array}$ & 鬼灯檠属 Rodgersia & R. pinnata Franch. & 云南丽江 Lijiang, Yunnan & & c. 75 & 15 & $5 x$ & & $\mathrm{PH}$ & OWT & Akiyama et al, 1990 \\
\hline 桦木科 Betulaceae & 桤木属 Alnus & A. cremastogyne Burk. & $\begin{array}{l}\text { 四川四川农大读书公园 Sichuan } \\
\text { Agricultural University, Ya’an, } \\
\text { Sichuan }\end{array}$ & & 56 & 14 & $4 \mathrm{x}$ & 650 & $\mathrm{~W}$ & NT & 任保青和刘军, 2006 \\
\hline 桦木科 Betulaceae & 桤木属 Alnus & A. ferdinandi-coburgii Schneid. & $\begin{array}{l}\text { 四川西昌市樟木乡 Zhangmuxiang, } \\
\text { Xichang, Sichuan }\end{array}$ & & 56 & 14 & $4 \mathrm{x}$ & 1,800 & $\mathrm{~W}$ & NT & 任保青和刘军, 2006 \\
\hline 桦木科 Betulaceae & 桤木属 Alnus & A. lanata Duthieex Bean & $\begin{array}{l}\text { 四川海螺沟国家公园 Hailuogou, } \\
\text { Sichuan }\end{array}$ & & 56 & 14 & $4 \mathrm{x}$ & 1,800 & W & NT & 任保青和刘军, 2006 \\
\hline 桦木科 Betulaceae & 桤木属 Alnus & A. nepalensis D. Don. & $\begin{array}{l}\text { 四川西昌市樟木乡 Zhangmuxiang, } \\
\text { Xichang, Sichuan }\end{array}$ & & 56 & 14 & $4 \mathrm{x}$ & 1,800 & $\mathrm{~W}$ & NT & 任保青和刘军, 2006 \\
\hline $\begin{array}{l}\text { 姜科 } \\
\text { Zingiberaceae }\end{array}$ & 象牙参属 Roscoea & R. tibetica Batalin & 云南丽江 Lijiang, Yunnan & & 24 & 12 & $2 \mathrm{x}$ & & $\mathrm{AH}$ & EA & 陈忠毅等, 1988 \\
\hline $\begin{array}{l}\text { 姜科 } \\
\text { Zingiberaceae }\end{array}$ & 舞花姜属 Globba & G. emeiensis Z. Y. Zhu & 四川峨眉山 Emei Mt., Sichuan & & 24 & 12 & $2 \mathrm{x}$ & & $\mathrm{PH}$ & TA \& TA & 陈忠毅等, 1988 \\
\hline 姜科 & 大苍姜属 & C. yunnanensis (Gagnep.) R. M. Sm. & 四川渡口 Dukou, Sichuan & & 42 & 21 & $2 \mathrm{x}$ & & PH & $\mathrm{TA}$ & 陈忠毅等, 1988 \\
\hline
\end{tabular}


王家坚, 彭智邦, 孙航, 聂泽龙, 孟盈. 青藏高原与横断山被子植物区系演化的细胞地理学特征. 生物多样性, 2017, 25 (2): 218-225.

http://www.biodiversity-science.net/CN/10.17520/biods.2016281

\begin{tabular}{|c|c|c|c|c|c|c|c|c|c|c|c|}
\hline 科名 Families & 属名 Genera & 种名 Species & 采集地点 Location & $\mathrm{n}$ & $2 \mathrm{n}$ & $\mathrm{x}$ & $\begin{array}{l}\text { 倍性 } \\
\text { Ploidy }\end{array}$ & $\begin{array}{l}\text { 海拔 } \\
\text { Altitude } \\
\text { (m) }\end{array}$ & $\begin{array}{l}\text { 生活型 } \\
\text { Life form }\end{array}$ & $\begin{array}{l}\text { 分布型 } \\
\text { Areal-type }\end{array}$ & 参考文献 Reference \\
\hline Zingiberaceae & Caulokaempferia & & & & & & & & & & \\
\hline $\begin{array}{l}\text { 桔梗科 } \\
\text { Campanulaceae }\end{array}$ & 沙参属 Adenophora & A. lobophylla D. Y. Hong & 四川金川 Jinchuan, Sichuan & & $34+2 \mathrm{~B}$ & 17 & $2 \mathrm{x}$ & & $\mathrm{PH}$ & oWT & 王可青和葛颂, 1998 \\
\hline $\begin{array}{l}\text { 桔梗科 } \\
\text { Campanulaceae }\end{array}$ & 沙参属 Adenophora & A. stricta Miq. & 四川金川 Jinchuan, Sichuan & & 68 & 17 & $4 \mathrm{x}$ & & $\mathrm{PH}$ & OWT & 王可青和葛颂, 1998 \\
\hline $\begin{array}{l}\text { 桔梗科 } \\
\text { Campanulaceae }\end{array}$ & $\begin{array}{l}\text { 蓝钟花属 } \\
\text { Cyananthus }\end{array}$ & C. cordifolius Duthie & Chaga, Gyirong, Tibet & & 14 & 7 & $2 \mathrm{x}$ & 4,277 & PH & EA & Chen et al, 2014 \\
\hline $\begin{array}{l}\text { 枯㤦科 } \\
\text { Campanulaceae }\end{array}$ & $\begin{array}{l}\text { 蓝钟花属 } \\
\text { Cyananthus }\end{array}$ & C. dolichosceles Marq & 四川得㭉 Pacong, Derong, Sichuan & & 10 & 5 & $2 \mathrm{x}$ & 4,129 & PH & EA & Chen et al, 2014 \\
\hline $\begin{array}{l}\text { 桔梗科 } \\
\text { Campanulaceae }\end{array}$ & $\begin{array}{l}\text { 蓝钟花属 } \\
\text { Cyananthus }\end{array}$ & C. formosus Diels & $\begin{array}{l}\text { 云南中甸 Shikashan, Zhongdian, } \\
\text { Yunnan }\end{array}$ & & 12 & 6 & $2 \mathrm{x}$ & 4,100 & PH & EA & Chen et al, 2014 \\
\hline $\begin{array}{l}\text { 桔梗科 } \\
\text { Campanulaceae }\end{array}$ & $\begin{array}{l}\text { 蓝钟花属 } \\
\text { Cyananthus }\end{array}$ & C. hookeri C. B. Clarke & $\begin{array}{l}\text { 四川得荣 De-Ba Pass, Derong, } \\
\text { Sichuan }\end{array}$ & & 24 & 6 & $4 \mathrm{x}$ & 4,129 & $\mathrm{AH}$ & EA & Chen et al, 2014 \\
\hline $\begin{array}{l}\text { 桔梗科 } \\
\text { Campanulaceae }\end{array}$ & $\begin{array}{l}\text { 蓝钟花属 } \\
\text { Cyananthus }\end{array}$ & C. hookeri C. B. Clarke & $\begin{array}{l}\text { 四川得荣噶金雪山 Gajin Mt., } \\
\text { Derong, Sichuan }\end{array}$ & & 24 & 6 & $4 \mathrm{x}$ & 4,300 & $\mathrm{AH}$ & EA & Chen et al, 2014 \\
\hline $\begin{array}{l}\text { 桔梗科 } \\
\text { Campanulaceae }\end{array}$ & $\begin{array}{l}\text { 蓝钟花属 } \\
\text { Cyananthus }\end{array}$ & C. hookeri C. B. Clarke & 西藏聂拉木 Nielamu, Tibet & & 24 & 6 & $4 \mathrm{x}$ & 3,881 & $\mathrm{AH}$ & EA & Chen et al, 2014 \\
\hline
\end{tabular}


王家坚, 彭智邦, 孙航, 聂泽龙, 孟盈. 青藏高原与横断山被子植物区系演化的细胞地理学特征. 生物多样性, 2017, 25 (2): 218-225.

http://www.biodiversity-science.net/CN/10.17520/biods.2016281

\begin{tabular}{|c|c|c|c|c|c|c|c|c|c|c|c|}
\hline 科名 Families & 属名 Genera & 种名 Species & 采集地点 Location & $\mathrm{n}$ & $2 \mathrm{n}$ & $\mathrm{x}$ & $\begin{array}{l}\text { 倍性 } \\
\text { Ploidy }\end{array}$ & $\begin{array}{l}\text { 海拔 } \\
\text { Altitude } \\
\text { (m) }\end{array}$ & $\begin{array}{l}\text { 生活型 } \\
\text { Life form }\end{array}$ & $\begin{array}{l}\text { 分布型 } \\
\text { Areal-type }\end{array}$ & 参考文献 Reference \\
\hline $\begin{array}{l}\text { 桔梗科 } \\
\text { Campanulaceae }\end{array}$ & $\begin{array}{l}\text { 蓝钟花属 } \\
\text { Cyananthus }\end{array}$ & C. hookeri C. B. Clarke & $\begin{array}{l}\text { 云南中甸大雪山 Snow Mt. } \\
\text { Zhongdian, Yunnan }\end{array}$ & & 12 & 6 & $2 \mathrm{x}$ & 4,323 & $\mathrm{AH}$ & EA & Chen et al, 2014 \\
\hline $\begin{array}{l}\text { 桔梗科 } \\
\text { Campanulaceae }\end{array}$ & $\begin{array}{l}\text { 蓝钟花属 } \\
\text { Cyananthus }\end{array}$ & C. incanus Hook. f. \& Thoms. & 四川巴塘 Batang, Sichuan & & 10 & 5 & $2 \mathrm{x}$ & 4,135 & PH & EA & Chen et al, 2014 \\
\hline $\begin{array}{l}\text { 桔梗科 } \\
\text { Campanulaceae }\end{array}$ & $\begin{array}{l}\text { 蓝钟花属 } \\
\text { Cyananthus }\end{array}$ & C. incanus Hook. f. \& Thoms. & Zelila, Yadong, Tibet & & 14 & 7 & $2 \mathrm{x}$ & 4,109 & $\mathrm{AH}$ & EA & Chen et al, 2014 \\
\hline $\begin{array}{l}\text { 桔梗科 } \\
\text { Campanulaceae }\end{array}$ & $\begin{array}{l}\text { 蓝钟花属 } \\
\text { Cyananthus }\end{array}$ & C. incanus Hook. f. \& Thoms. & 西藏聂拉木 Nielamu, Tibet & & 10 & 5 & $2 \mathrm{x}$ & 3,881 & PH & EA & Chen et al, 2014 \\
\hline $\begin{array}{l}\text { 桔梗科 } \\
\text { Campanulaceae }\end{array}$ & $\begin{array}{l}\text { 蓝钟花属 } \\
\text { Cyananthus }\end{array}$ & C. inflatus Hook. f. \& Thoms. & 西藏错那 Mama, Cuona, Tibet & & 28 & 7 & $4 \mathrm{x}$ & 3,583 & $\mathrm{AH}$ & EA & Chen et al, 2014 \\
\hline $\begin{array}{l}\text { 桔梗科 } \\
\text { Campanulaceae }\end{array}$ & $\begin{array}{l}\text { 蓝钟花属 } \\
\text { Cyananthus }\end{array}$ & C. inflatus Hook. f. \& Thoms. & 西藏林芝 Sejilashan, Tibet & & 14 & 7 & $2 \mathrm{x}$ & 4,300 & $\mathrm{AH}$ & EA & Chen et al, 2014 \\
\hline $\begin{array}{l}\text { 桔梗科 } \\
\text { Campanulaceae }\end{array}$ & $\begin{array}{l}\text { 蓝钟花属 } \\
\text { Cyananthus }\end{array}$ & C. inflatus Hook. f. \& Thoms. & 四川西昌 Xichang, Sichuan & & 28 & 7 & $4 \mathrm{x}$ & 1,534 & $\mathrm{AH}$ & EA & Chen et al, 2014 \\
\hline $\begin{array}{l}\text { 桔梗科 } \\
\text { Campanulaceae }\end{array}$ & $\begin{array}{l}\text { 蓝钟花属 } \\
\text { Cyananthus }\end{array}$ & C. lichiangensis W. W. Sm. & $\begin{array}{l}\text { 四川乡城大雪山 Snow Mt., } \\
\text { Xiangcheng, Sichuan }\end{array}$ & & 14 & 7 & $2 \mathrm{x}$ & 4,360 & $\mathrm{AH}$ & EA & Chen et al, 2014 \\
\hline $\begin{array}{l}\text { 桔梗科 } \\
\text { Campanulaceae }\end{array}$ & $\begin{array}{l}\text { 蓝钟花属 } \\
\text { Cyananthus }\end{array}$ & C. lichiangensis W. W. Sm. & $\begin{array}{l}\text { 云南中甸大雪山 Snow Mt. } \\
\text { Zhongdian, Yunnan }\end{array}$ & & 14 & 7 & $2 \mathrm{x}$ & 4,323 & $\mathrm{AH}$ & EA & Chen et al, 2014 \\
\hline $\begin{array}{l}\text { 桔梗科 } \\
\text { Campanulaceae }\end{array}$ & $\begin{array}{l}\text { 蓝钟花属 } \\
\text { Cyananthus }\end{array}$ & C. lobatus Wall. ex Benth & Zelila, Yadong, Tibet & & 14 & 7 & $2 \mathrm{x}$ & 4,109 & PH & EA & Chen et al, 2014 \\
\hline $\begin{array}{l}\text { 桔梗科 } \\
\text { Campanulaceae }\end{array}$ & $\begin{array}{l}\text { 蓝钟花属 } \\
\text { Cyananthus }\end{array}$ & C. longiflorus Franch & $\begin{array}{l}\text { 云南丽江玉龙雪山 Yulong Mt., } \\
\text { Lijiang, Yunnan }\end{array}$ & & 12 & 6 & $2 \mathrm{x}$ & 3,200 & PH & EA & Chen et al, 2014 \\
\hline 桔梗科 & 蓝钟花属 & C. macrocalyx Franch. & 四川得荣噶金雪山 Gajin Mt., & & 10 & 5 & $2 \mathrm{x}$ & 4,300 & PH & EA & Chen et al, 2014 \\
\hline
\end{tabular}


王家坚, 彭智邦, 孙航, 聂泽龙, 孟盈. 青藏高原与横断山被子植物区系演化的细胞地理学特征. 生物多样性, 2017, 25 (2): 218-225.

http://www.biodiversity-science.net/CN/10.17520/biods.2016281

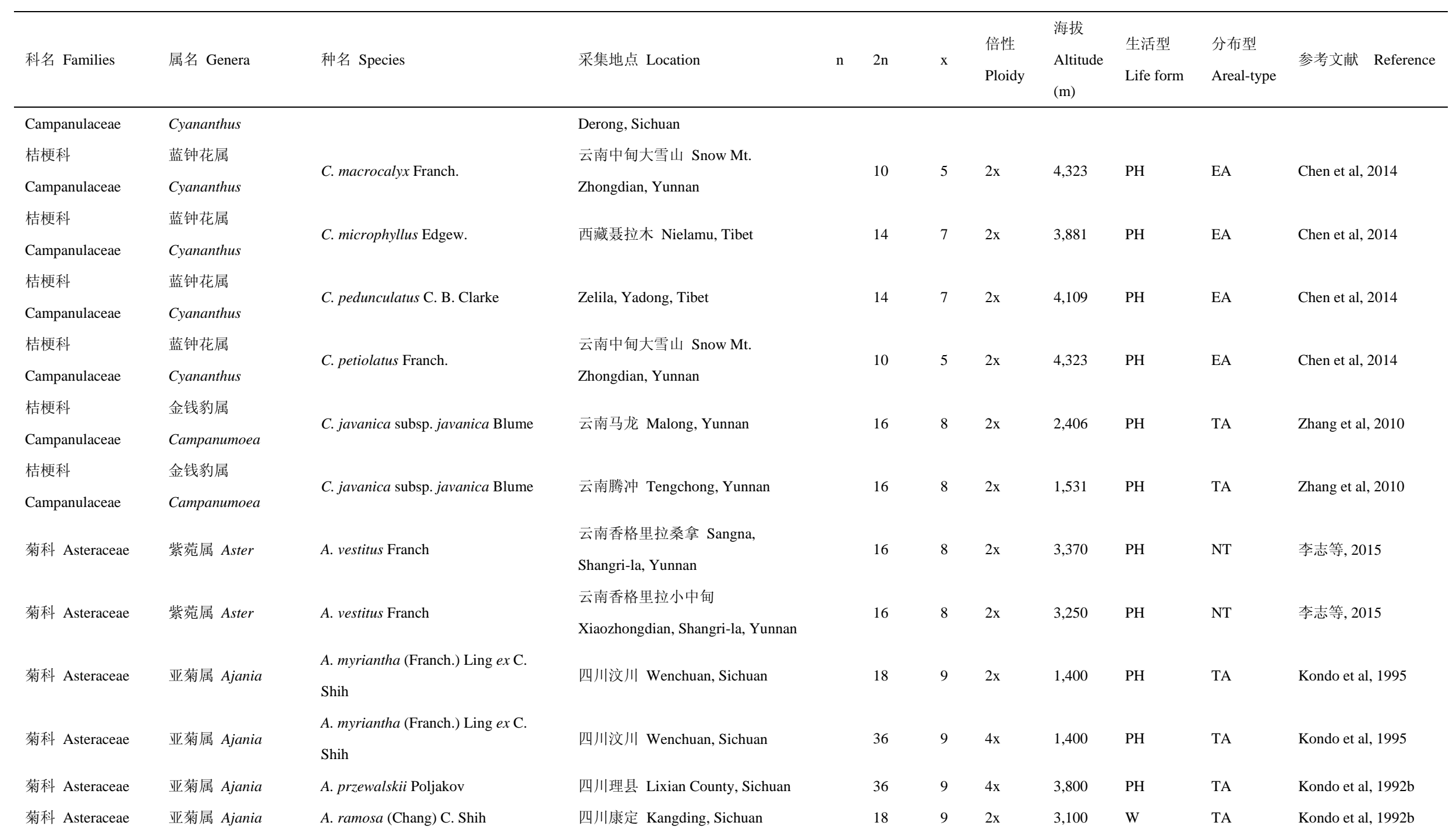


王家坚, 彭智邦, 孙航, 聂泽龙, 孟盈. 青藏高原与横断山被子植物区系演化的细胞地理学特征. 生物多样性, 2017, 25 (2): 218-225.

http://www.biodiversity-science.net/CN/10.17520/biods.2016281

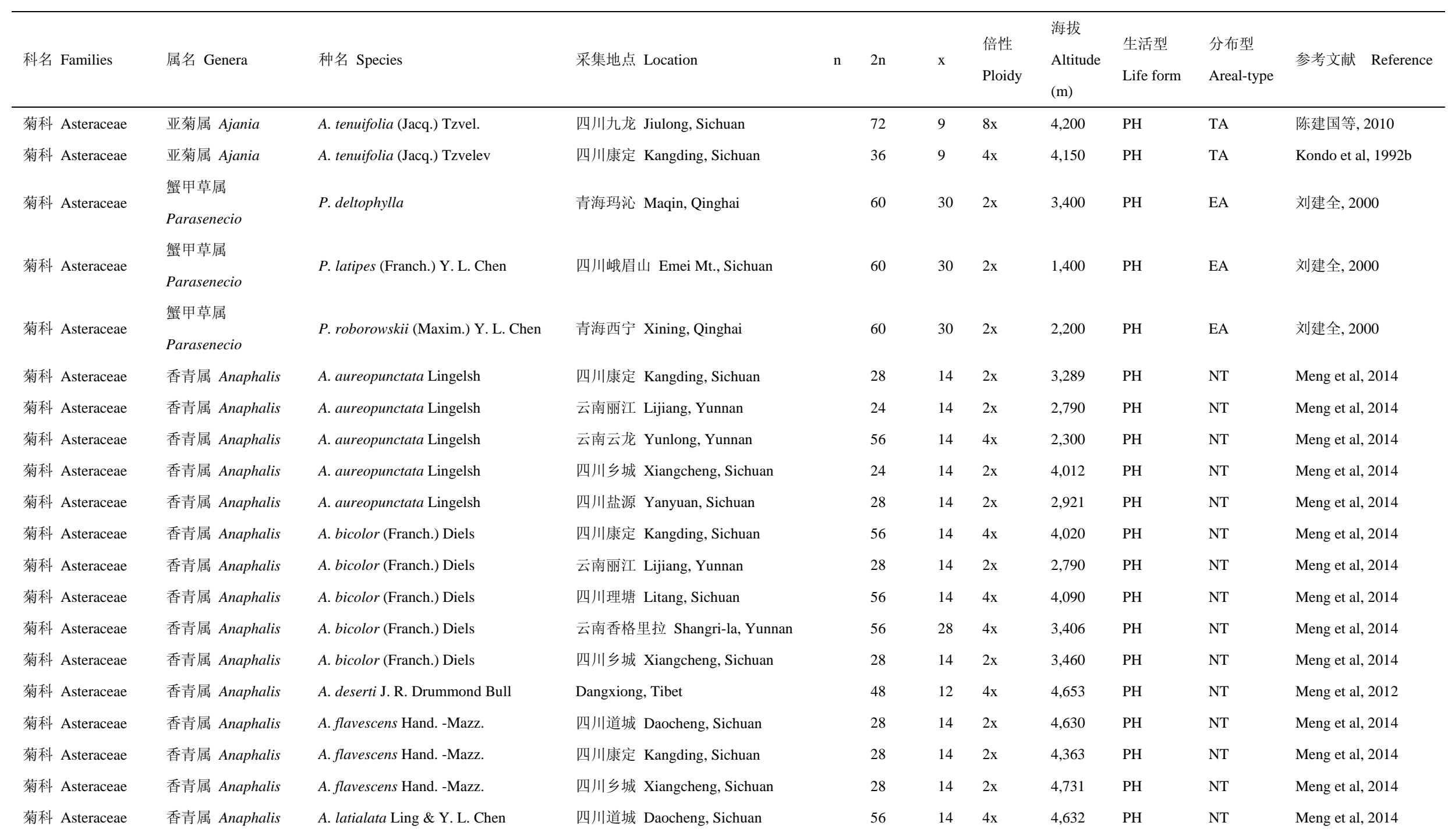


王家坚, 彭智邦, 孙航, 聂泽龙, 孟盈. 青藏高原与横断山被子植物区系演化的细胞地理学特征. 生物多样性, 2017, 25 (2): 218-225.

http://www.biodiversity-science.net/CN/10.17520/biods.2016281

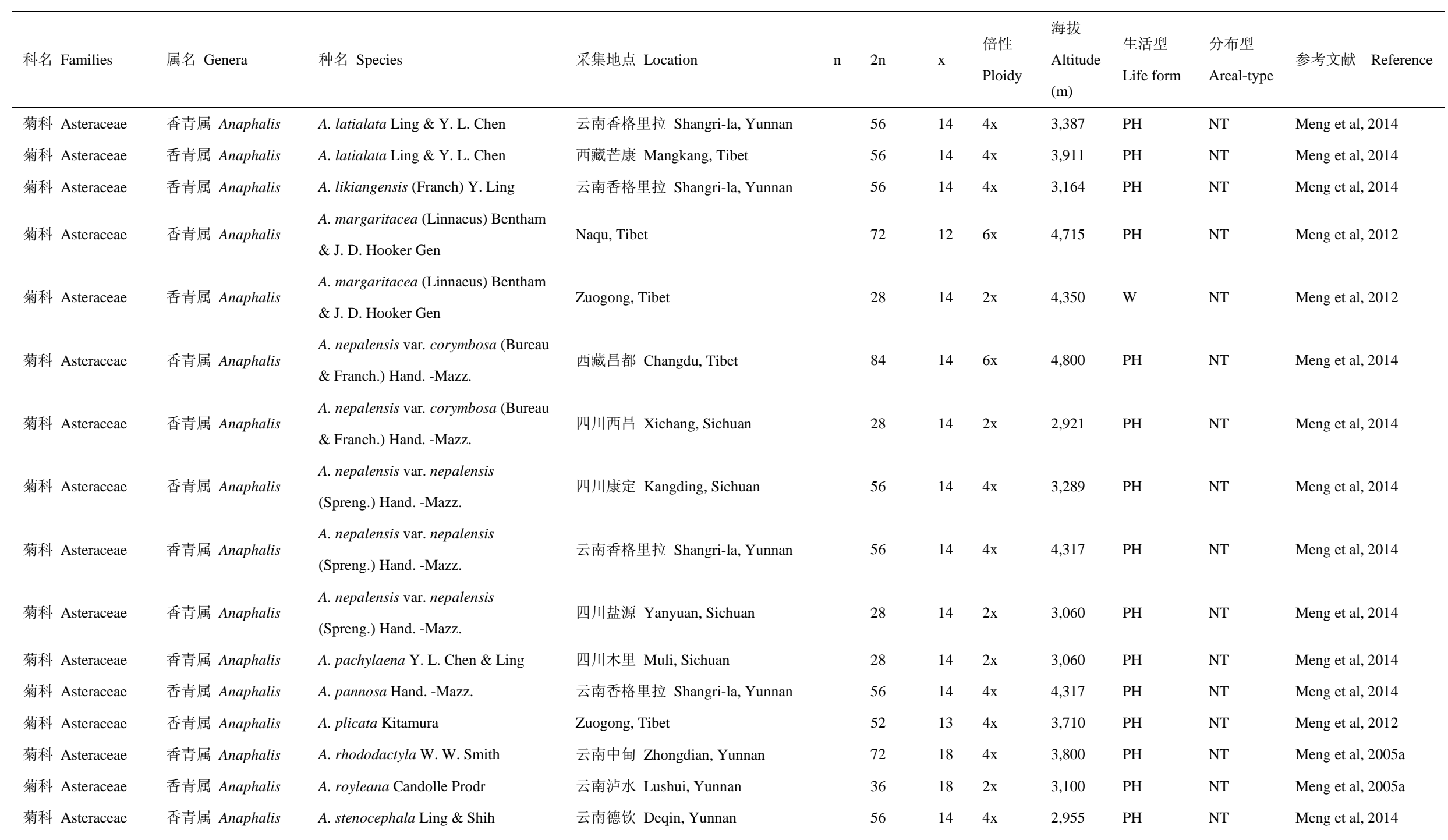


王家坚, 彭智邦, 孙航, 聂泽龙, 孟盈. 青藏高原与横断山被子植物区系演化的细胞地理学特征. 生物多样性, 2017, 25 (2): 218-225.

http://www.biodiversity-science.net/CN/10.17520/biods.2016281

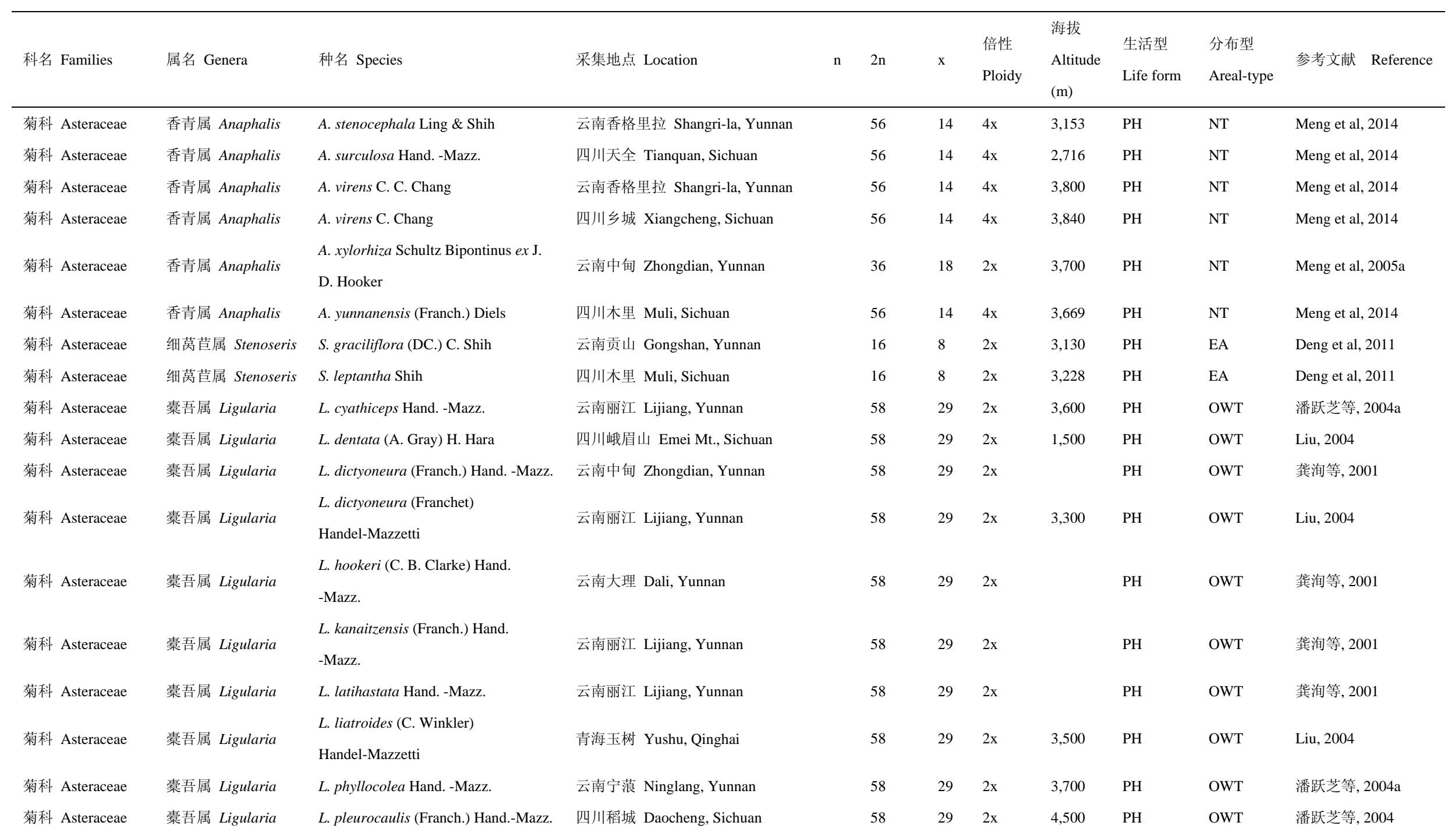


王家坚, 彭智邦, 孙航, 聂泽龙, 孟盈. 青藏高原与横断山被子植物区系演化的细胞地理学特征. 生物多样性, 2017, 25 (2): 218-225.

http://www.biodiversity-science.net/CN/10.17520/biods.2016281

\begin{tabular}{|c|c|c|c|c|c|c|c|c|c|c|c|}
\hline 科名 Families & 属名 Genera & 种名 Species & 采集地点 Location & $\mathrm{n}$ & $2 \mathrm{n}$ & $\mathrm{x}$ & $\begin{array}{l}\text { 倍性 } \\
\text { Ploidy }\end{array}$ & $\begin{array}{l}\text { 海拔 } \\
\text { Altitude } \\
\text { (m) }\end{array}$ & $\begin{array}{l}\text { 生活型 } \\
\text { Life form }\end{array}$ & $\begin{array}{l}\text { 分布型 } \\
\text { Areal-type }\end{array}$ & 参考文献 Reference \\
\hline 菊科 Asteraceae & 栗吾属 Ligularia & L. pleurocaulis (Franch.) Hand.-Mazz. & 云南中甸 Zhongdian, Yunnan & & 58 & 29 & $2 \mathrm{x}$ & 3,200 & PH & OWT & 潘跃芝等, 2004 \\
\hline 菊科 Asteraceae & 重吾属 Ligularia & L. stenocephala Matsum. \& Koidzumi & 云南大理 Dali, Yunnan & & 58 & 29 & $2 \mathrm{x}$ & & PH & OWT & 龚洵等, 2001 \\
\hline 菊科 Asteraceae & 輠吾属 Ligularia & L. tangutorum Pojarkova & 青海玛沈 Maqin, Qinghai & & 58 & 29 & $2 \mathrm{x}$ & 3,200 & PH & OWT & Liu, 2004 \\
\hline 菊科 Asteraceae & 䍒吾属 Ligularia & L. tongolensis (Franch.) Hand. -Mazz. & 云南中甸 Zhongdian, Yunnan & & 58 & 29 & $2 \mathrm{x}$ & 3,200 & PH & OWT & 潘跃芝等, 2004a \\
\hline 菊科 Asteraceae & 䍒吾属 Ligularia & L. vellerea Hand. -Mazz. & 云南丽江 Lijiang, Yunnan & & 58 & 29 & $2 \mathrm{x}$ & & PH & OWT & 龚洵等, 2001 \\
\hline 菊科 Asteraceae & 囊吾属 Ligularia & $\begin{array}{l}\text { L. virgaurea (Maximowicz) Mattfeld } \\
\text { ex Rehder \& Kobuski }\end{array}$ & 四川若尔盖 Ruoergai, Sichuan & & 58 & 29 & $2 \mathrm{x}$ & & $\mathrm{PH}$ & OWT & Liu, 2004 \\
\hline 菊科 Asteraceae & 囊吾属 Ligularia & $\begin{array}{l}\text { L. virgaurea (Maximowicz) Mattfeld } \\
\text { ex Rehder \& Kobuski }\end{array}$ & 青海玛沋 Maqin, Qinghai & & 87 & 29 & $3 \mathrm{x}$ & 3,700 & $\mathrm{PH}$ & OWT & Liu, 2004 \\
\hline 菊科 Asteraceae & 肉菊属 Stebbinsia & S. umbrella (Franch.) Lipschitz & 西藏林芝色季拉 Sejila, Linzhi, Tibet & & 16 & 8 & $2 \mathrm{x}$ & 4,450 & PH & $\mathrm{EA}$ & Zhang et al, 2007 \\
\hline 菊科 Asteraceae & $\begin{array}{l}\text { 毛鳞菊属 } \\
\text { Chaetoseris }\end{array}$ & C. beesiana (Diels) C. Shih & 云南丽江 Lijiang, Yunnan & & 16 & 8 & $2 \mathrm{x}$ & 2,790 & PH & EA & Deng et al, 2011 \\
\hline 菊科 Asteraceae & $\begin{array}{l}\text { 毛鳞菊属 } \\
\text { Chaetoseris }\end{array}$ & C. cyanea (D. Don) C. Shih & 云南大理 Dali, Yunnan & & 16 & 8 & $2 \mathrm{x}$ & 2,419 & $\mathrm{PH}$ & EA & Deng et al, 2011 \\
\hline 菊科 Asteraceae & $\begin{array}{l}\text { 毛鳞菊属 } \\
\text { Chaetoseris }\end{array}$ & C. cyanea (D. Don) C. Shih & 云南大理 Dali, Yunnan & & 16 & 8 & $2 \mathrm{x}$ & 2,540 & $\mathrm{PH}$ & EA & Deng et al, 2011 \\
\hline 菊科 Asteraceae & 毛鳞菊属 & C. dolichophylla Shih & 云南丽江 Lijiang, Yunnan & & 16 & 8 & $2 \mathrm{x}$ & 2,790 & $\mathrm{PH}$ & EA & Deng et al, 2011 \\
\hline
\end{tabular}


王家坚, 彭智邦, 孙航, 聂泽龙, 孟盈. 青藏高原与横断山被子植物区系演化的细胞地理学特征. 生物多样性, 2017, 25 (2): 218-225.

http://www.biodiversity-science.net/CN/10.17520/biods.2016281

\begin{tabular}{|c|c|c|c|c|c|c|c|c|c|c|c|}
\hline 科名 Families & 属名 Genera & 种名 Species & 采集地点 Location & $\mathrm{n}$ & $2 n$ & $\mathrm{x}$ & $\begin{array}{l}\text { 倍性 } \\
\text { Ploidy }\end{array}$ & $\begin{array}{l}\text { 海拔 } \\
\text { Altitude } \\
(\mathrm{m})\end{array}$ & $\begin{array}{l}\text { 生活型 } \\
\text { Life form }\end{array}$ & $\begin{array}{l}\text { 分布型 } \\
\text { Areal-type }\end{array}$ & 参考文献 Reference \\
\hline & Chaetoseris & & & & & & & & & & \\
\hline 菊科 Asteraceae & $\begin{array}{l}\text { 毛鳞菊属 } \\
\text { Chaetoseris }\end{array}$ & C. grandiflora (Franch.) Shih & 云南贡山 Gongshan, Yunnan & & 16 & 8 & $2 \mathrm{x}$ & 3,130 & $\mathrm{PH}$ & EA & Deng et al, 2011 \\
\hline 菊科 Asteraceae & $\begin{array}{l}\text { 毛鳞菊属 } \\
\text { Chaetoseris }\end{array}$ & C. hastata (Wall. ex DC.) Shih & 云南贡山 Gongshan, Yunnan & & 16 & 8 & $2 \mathrm{x}$ & 3,130 & $\mathrm{PH}$ & EA & Deng et al, 2011 \\
\hline 菊科 Asteraceae & $\begin{array}{l}\text { 毛鳞菊属 } \\
\text { Chaetoseris }\end{array}$ & C. likiangensis (Franch.) Shih & 云南丽江 Lijiang, Yunnan & & 16 & 8 & $2 \mathrm{x}$ & 2,790 & $\mathrm{PH}$ & EA & Deng et al, 2011 \\
\hline 菊科 Asteraceae & $\begin{array}{l}\text { 毛鳞菊属 } \\
\text { Chaetoseris }\end{array}$ & C. lyriformis Shih & 四川康定 Kangding, Sichuan & & 16 & 8 & $2 \mathrm{x}$ & 3,289 & $\mathrm{PH}$ & EA & Deng et al, 2011 \\
\hline 菊科 Asteraceae & $\begin{array}{l}\text { 毛鳞菊属 } \\
\text { Chaetoseris }\end{array}$ & C. lyriformis Shih & 云南中甸 Zhongdian, Yunnan & & 16 & 8 & $2 \mathrm{x}$ & 3,164 & $\mathrm{PH}$ & EA & Deng et al, 2011 \\
\hline 菊科 Asteraceae & $\begin{array}{l}\text { 毛鳞菊属 } \\
\text { Chaetoseris }\end{array}$ & C. taliensis Shih & 云南丽江 Lijiang, Yunnan & & 16 & 8 & $2 \mathrm{x}$ & 2,790 & $\mathrm{PH}$ & EA & Deng et al, 2011 \\
\hline 菊科 Asteraceae & 毛连菜属 Picris & $\begin{array}{l}\text { P. hieracioides } L \text {. subsp. japonica } \\
\text { Krylv. }\end{array}$ & 四川宝兴 Baoxing, Sichuan & & 14 & 7 & $2 \mathrm{x}$ & 2,600 & $\mathrm{AH}$ & NT & Hong \& Zhang, 1990 \\
\hline 菊科 Asteraceae & $\begin{array}{l}\text { 毛冠菊属 } \\
\text { Nannoglottis }\end{array}$ & $\begin{array}{l}\text { N. gynura (C. Winkler) Ling \& Y. L. } \\
\text { Chen }\end{array}$ & 青海玉树 Yushu, Qinghai & & 18 & 9 & $2 \mathrm{x}$ & 3,600 & $\mathrm{PH}$ & EC & 刘建全等, 2000a \\
\hline 菊科 Asteraceae & 栌菊木属 Nouelia & N. insignis Franch. & 云南中甸 Zhongdian, Yunnan & & 54 & 9 & $6 \mathrm{x}$ & 1,988 & $\mathrm{~W}$ & EC & 彭玉兰等, 2002 \\
\hline 菊科 Asteraceae & 苦亘菜属 Sonchus & S. arvensis $\mathrm{L}$. & 四川峨眉山 Emei Mt., Sichuan & 8 & & 8 & $2 \mathrm{x}$ & 1,700 & $\mathrm{PH}$ & NT & Hong \& Zhang, 1990 \\
\hline 菊科 Asteraceae & 绢毛芭属 Soroseris & S. erysimoides (H. -M.) C. Shih & 西藏类乌齐 Leiwuqi, Tibet & & 16 & 8 & $2 \mathrm{x}$ & 4,500 & $\mathrm{AH}$ & EC & Zhang et al, 2009 \\
\hline 菊科 Asteraceae & 绢毛芭属 Soroseris & S. erysimoides (H. -M.) C. Shih & 西藏南木林县 Nanmulin, Tibet & & 16 & 8 & $2 \mathrm{x}$ & 4,200 & $\mathrm{PH}$ & EC & Zhang et al, 2009 \\
\hline 菊科 Asteraceae & 绢毛亘属 Soroseris & S. gillii (S. Moore) Stebbins & 四川甘孜 Ganzi, Sichuan & & 42 & 7 & $6 \mathrm{x}$ & & $\mathrm{PH}$ & $\mathrm{CA}$ & Zhang et al, 1998 \\
\hline 菊科 Asteraceae & 绢毛芭属 Soroseris & S. gillii (S. Moore) Stebbins & 四川雅安 Ya’an, Sichuan & & 42 & 7 & $6 \mathrm{x}$ & & $\mathrm{PH}$ & OWT & Zhang et al, 1998 \\
\hline
\end{tabular}


王家坚, 彭智邦, 孙航, 聂泽龙, 孟盈. 青藏高原与横断山被子植物区系演化的细胞地理学特征. 生物多样性, 2017, 25 (2): 218-225.

http://www.biodiversity-science.net/CN/10.17520/biods.2016281

\begin{tabular}{|c|c|c|c|c|c|c|c|c|c|c|c|}
\hline 科名 Families & 属名 Genera & 种名 Species & 采集地点 Location & $\mathrm{n}$ & $2 n$ & $\mathrm{x}$ & $\begin{array}{l}\text { 倍性 } \\
\text { Ploidy }\end{array}$ & $\begin{array}{l}\text { 海拔 } \\
\text { Altitude } \\
\text { (m) }\end{array}$ & $\begin{array}{l}\text { 生活型 } \\
\text { Life form }\end{array}$ & $\begin{array}{l}\text { 分布型 } \\
\text { Areal-type }\end{array}$ & 参考文献 Reference \\
\hline 菊科 Asteraceae & 绢毛苣属 Soroseris & S. glomerata (Decne.) Stebbins & $\begin{array}{l}\text { 云南德钦白马山 Baima Mt., Deqin, } \\
\text { Yunnan }\end{array}$ & & 16 & 8 & $2 \mathrm{x}$ & 4,600 & PH & EA & Zhang et al, 2007 \\
\hline 菊科 Asteraceae & 绢毛苣属 Soroseris & S. glomerata (Decne.) Stebbins & $\begin{array}{l}\text { 四川康定折多山 Zheduo Mt., } \\
\text { Kangding, Sichuan }\end{array}$ & & 16 & 8 & $2 \mathrm{x}$ & 4,500 & $\mathrm{PH}$ & EA & Zhang et al, 2007 \\
\hline 菊科 Asteraceae & 绢毛苣属 Soroseris & S. hirsuta (Anth.) C. Shih & $\begin{array}{l}\text { 四川康定折多山 Zheduo Mt., } \\
\text { Kangding, Sichuan }\end{array}$ & & 32 & 8 & $4 \mathrm{x}$ & 4,400 & PH & EA & Zhang et al, 2007 \\
\hline 菊科 Asteraceae & 绢毛苣属 Soroseris & S. hirsuta (Anth.) C. Shih & $\begin{array}{l}\text { 云南中甸红山 Hong Mt., Zhongdian, } \\
\text { Yunnan }\end{array}$ & & 16 & 8 & $2 \mathrm{x}$ & 4,420 & PH & EA & Zhang et al, 2007 \\
\hline 菊科 Asteraceae & 绢毛苣属 Soroseris & S. hookeriana (C. B. Clarke) Stebbins & $\begin{array}{l}\text { 西藏羊八井雪古拉 Xuegula, } \\
\text { Yangbajing, Tibet }\end{array}$ & & 16 & 8 & $2 \mathrm{x}$ & 5,500 & PH & EA & Zhang et al, 2007 \\
\hline 菊科 Asteraceae & 绢毛苣属 Soroseris & S. teres C. Shih & $\begin{array}{l}\text { 云南德钦白马山 Baima Mt., Deqin, } \\
\text { Yunnan }\end{array}$ & & 32 & 8 & $4 \mathrm{x}$ & 4,620 & PH & EA & Zhang et al, 2007 \\
\hline 菊科 Asteraceae & 绢蒿属 Seriphidium & S. borotalense (Poljak.) Ling et Y. R. & 新疆博乐县 Bole, Xinjiang & & 18 & 9 & $2 \mathrm{x}$ & 447 & $\mathrm{PH}$ & NT & $\begin{array}{l}\text { 贺学礼和张妙娟, } \\
2009\end{array}$ \\
\hline 菊科 Asteraceae & 绢蒿属 Seriphidium & S. minchünensa Y. R. & 甘肃民勤 Minqin, Gansu & & 18 & 9 & $2 \mathrm{x}$ & 1,436 & $\mathrm{PH}$ & NT & $\begin{array}{l}\text { 贺学礼和张妙娟, } \\
2009\end{array}$ \\
\hline 菊科 Asteraceae & 菊属 Dendranthema & $\begin{array}{l}\text { D. glabriusculum (W. W. Sm.) C. } \\
\text { Shih }\end{array}$ & 四川昭觉 Zhaojue, Sichuan & & 54 & 9 & $6 \mathrm{x}$ & 1,950 & $\mathrm{PH}$ & OWT & Kondo et al, 1998 \\
\hline 菊科 Asteraceae & 菊属 Dendranthema & $\begin{array}{l}\text { D. lavandulifolium (Fisch. ex Trautv.) } \\
\text { Y. Ling \& C. Shih }\end{array}$ & 云南云龙 Yunlong, Yunnan & & 36 & 18 & $2 \mathrm{x}$ & 2,800 & $\mathrm{PH}$ & NT & 汪劲武等, 1993 \\
\hline 菊科 Asteraceae & 菊属 Aster & A. diplostephioides Benth. \& Hook. F. & 青海玉树 Yushu, Qinghai & & 18 & 9 & $2 \mathrm{x}$ & 3,850 & PH & NT & 刘建全, 1999 \\
\hline 菊科 Asteraceae & 菊属 Aster & A. nitidus Chang & 四川理县 Lixian County, Sichuan & & 16 & 8 & $2 \mathrm{x}$ & 2,100 & $\mathrm{PH}$ & NT & 殷根深等, 2010 \\
\hline 菊科 Asteraceae & 菊属 Aster & A. souliei Franchet J. & 青海玉树 Yushu, Qinghai & & 18 & 9 & $2 \mathrm{x}$ & 3,950 & $\mathrm{PH}$ & NT & 刘建全, 1999 \\
\hline
\end{tabular}


王家坚, 彭智邦, 孙航, 聂泽龙, 孟盈. 青藏高原与横断山被子植物区系演化的细胞地理学特征. 生物多样性, 2017, 25 (2): 218-225.

http://www.biodiversity-science.net/CN/10.17520/biods.2016281

\begin{tabular}{|c|c|c|c|c|c|c|c|c|c|c|c|}
\hline 科名 Families & 属名 Genera & 种名 Species & 采集地点 Location & $\mathrm{n}$ & $2 \mathrm{n}$ & $\mathrm{x}$ & $\begin{array}{l}\text { 倍性 } \\
\text { Ploidy }\end{array}$ & $\begin{array}{l}\text { 海拔 } \\
\text { Altitude } \\
\text { (m) }\end{array}$ & $\begin{array}{l}\text { 生活型 } \\
\text { Life form }\end{array}$ & $\begin{array}{l}\text { 分布型 } \\
\text { Areal-type }\end{array}$ & 参考文献 Reference \\
\hline 菊科 Asteraceae & 菊属 Aster & $\begin{array}{l}\text { A. yunnanensis var. labrangensis } \\
\text { (Handel-Mazzetti) Y. Ling }\end{array}$ & 青海玉树 Yushu, Qinghai & & 18 & 9 & $2 \mathrm{x}$ & 3,850 & $\mathrm{~W}$ & NT & 刘建全, 1999 \\
\hline 菊科 Asteraceae & $\begin{array}{l}\text { 火线草属 } \\
\text { Leontopodium }\end{array}$ & L. artemisiifolium Beauverd & 云南中甸 Zhongdian, Yunnan & & 26 & 12 & $2 \mathrm{x}$ & 2,873 & $\mathrm{PH}$ & NT & Anton et al, 2013 \\
\hline 菊科 Asteraceae & $\begin{array}{l}\text { 火线草属 } \\
\text { Leontopodium }\end{array}$ & L. calocephalum (Franch) P. Beauv & 四川甘孜 Ganzi, Sichuan & & 48 & 12 & $4 \mathrm{x}$ & 4,012 & $\mathrm{PH}$ & NT & 王广艳等, 2013 \\
\hline 菊科 Asteraceae & $\begin{array}{l}\text { 火线草属 } \\
\text { Leontopodium }\end{array}$ & L. cf. stracheyi C.B.Clarke ex Hemsl & 云南维西 Weixi, Yunnan & & 26 & 13 & $2 \mathrm{x}$ & 2,868 & $\mathrm{PH}$ & NT & Anton et al, 2013 \\
\hline 菊科 Asteraceae & $\begin{array}{l}\text { 火线草属 } \\
\text { Leontopodium }\end{array}$ & L. dedekensii Beauverd & 云南奔子栏 Benzilan, Yunnan & & 26 & 13 & $2 \mathrm{x}$ & 2,780 & $\mathrm{PH}$ & NT & Anton et al, 2013 \\
\hline 菊科 Asteraceae & $\begin{array}{l}\text { 火线草属 } \\
\text { Leontopodium }\end{array}$ & L. dedekensii Beauverd & 云南丙中洛 Bingzhongluo, Yunnan & & 26 & 13 & $2 \mathrm{x}$ & 1,692 & $\mathrm{PH}$ & NT & Anton et al, 2013 \\
\hline 菊科 Asteraceae & $\begin{array}{l}\text { 火线草属 } \\
\text { Leontopodium }\end{array}$ & L. dedekensii Beauverd & 云南德钦 Deqin, Yunnan & & 26 & 13 & $2 \mathrm{x}$ & 2,997 & $\mathrm{PH}$ & NT & Anton et al, 2013 \\
\hline 菊科 Asteraceae & $\begin{array}{l}\text { 火线草属 } \\
\text { Leontopodium }\end{array}$ & L. franchetii Beauv. & 云南中甸 Zhongdian, Yunnan & & 26 & 13 & $2 \mathrm{x}$ & 3,406 & $\mathrm{PH}$ & NT & 王广艳等, 2013 \\
\hline 菊科 Asteraceae & $\begin{array}{l}\text { 火线草属 } \\
\text { Leontopodium }\end{array}$ & L. himalayanum DC. & 云南德钦 Deqin, Yunnan & & 24 & 12 & $2 \mathrm{x}$ & 4,316 & $\mathrm{PH}$ & NT & Anton et al, 2013 \\
\hline 菊科 Asteraceae & $\begin{array}{l}\text { 火线草属 } \\
\text { Leontopodium }\end{array}$ & L. japonicum Miq. & $\begin{array}{l}\text { Living collection of the } \\
\text { University of Vienna } \\
\text { Botanical Garden }\end{array}$ & & 26 & 13 & $2 \mathrm{x}$ & & $\mathrm{PH}$ & NT & Anton et al, 2013 \\
\hline 菊科 Asteraceae & $\begin{array}{l}\text { 火线草属 } \\
\text { Leontopodium }\end{array}$ & L. japonicum Miq. & $\begin{array}{l}\text { Living collection of the } \\
\text { University of Vienna }\end{array}$ & & 52 & 13 & $4 \mathrm{x}$ & & $\mathrm{PH}$ & NT & Anton et al, 2013 \\
\hline
\end{tabular}


王家坚, 彭智邦, 孙航, 聂泽龙, 孟盈. 青藏高原与横断山被子植物区系演化的细胞地理学特征. 生物多样性, 2017, 25 (2): 218-225.

http://www.biodiversity-science.net/CN/10.17520/biods.2016281

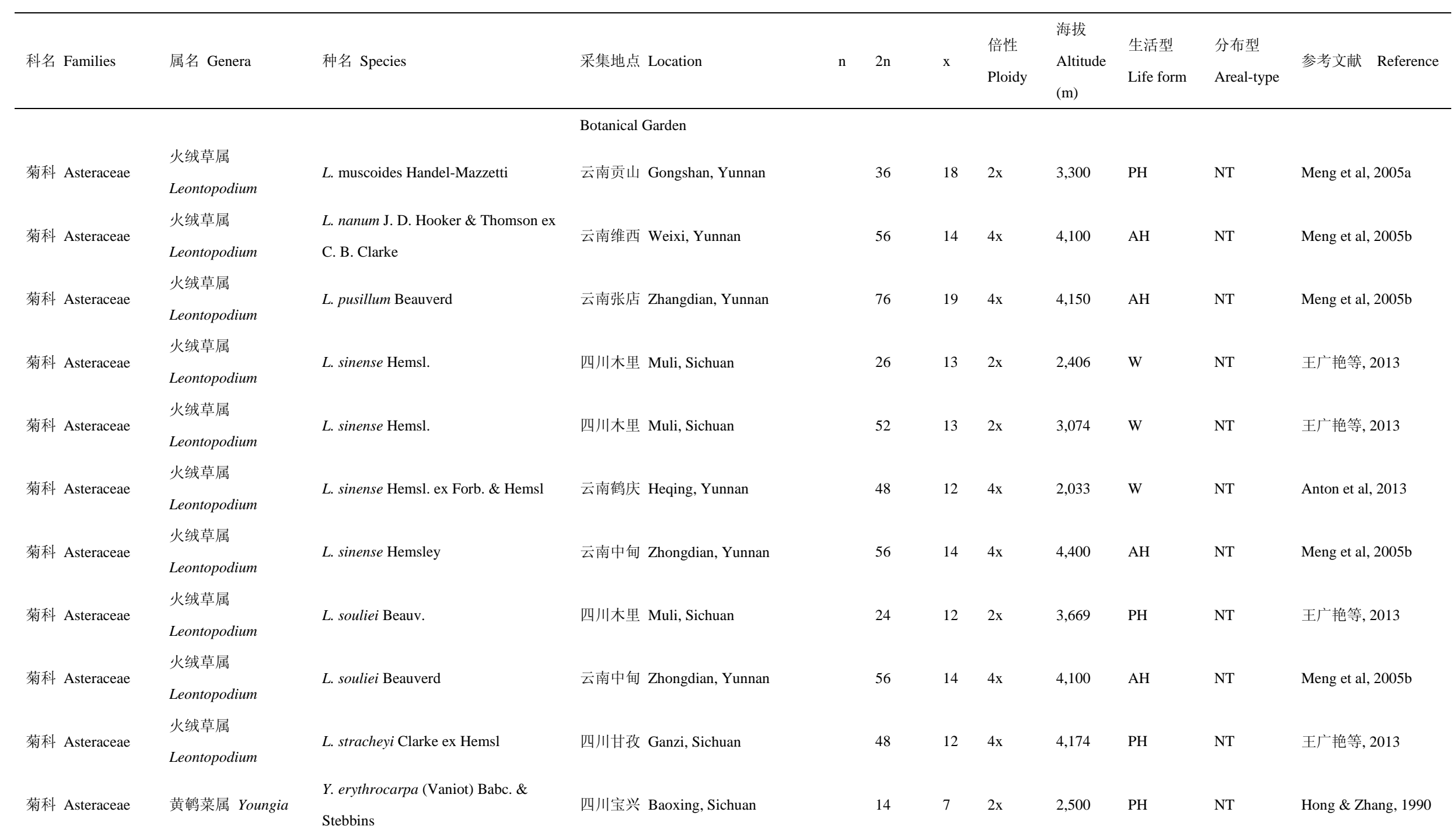


王家坚, 彭智邦, 孙航, 聂泽龙, 孟盈. 青藏高原与横断山被子植物区系演化的细胞地理学特征. 生物多样性, 2017, 25 (2): 218-225.

http://www.biodiversity-science.net/CN/10.17520/biods.2016281

\begin{tabular}{|c|c|c|c|c|c|c|c|c|c|c|c|c|}
\hline 科名 & Families & 属名 Genera & 种名 Species & 采集地点 Location & $\mathrm{n}$ & $2 \mathrm{n}$ & $\mathrm{x}$ & $\begin{array}{l}\text { 倍性 } \\
\text { Ploidy }\end{array}$ & $\begin{array}{l}\text { 海拔 } \\
\text { Altitude } \\
(\mathrm{m})\end{array}$ & $\begin{array}{l}\text { 生活型 } \\
\text { Life form }\end{array}$ & $\begin{array}{l}\text { 分布型 } \\
\text { Areal-type }\end{array}$ & 参考文献 Reference \\
\hline 菊科 & Asteraceae & 黄鹤菜属 Youngia & $\begin{array}{l}\text { Y. heterophylla (Hemsl.) Babcock \& } \\
\text { Stebbins }\end{array}$ & 四川峨眉山 Emei Mt., Sichuan & & 16 & 8 & $2 \mathrm{x}$ & 1,600 & PH & NT & Hong \& Zhang, 1990 \\
\hline 菊科 & Asteraceae & 华蟹甲属 Sinacalia & S. tangutica (Maxim.) B. Nord. & Xunhua \& Huzhu, Qinghai & & 60 & 30 & $2 \mathrm{x}$ & 1,800 & PH & EC & 刘建全, 2000 \\
\hline 菊科 & Asteraceae & $\begin{array}{l}\text { 合头菊属 } \\
\text { Syncalathium }\end{array}$ & S. chrysocephalum (C. Shih) S.W. Liu & 西藏亚东帕里 Pali, Yadong, Tibet & & 16 & 8 & $2 \mathrm{x}$ & 4,100 & PH & EA & Zhang et al, 2007 \\
\hline 菊科 & Asteraceae & $\begin{array}{l}\text { 合头菊属 } \\
\text { Syncalathium }\end{array}$ & S. disciforme (Mattf.) Y. Ling & $\begin{array}{l}\text { 西藏昌都达马拉龙 Damalalong, } \\
\text { Changdu, Tibet }\end{array}$ & & 16 & 8 & $2 \mathrm{x}$ & 4,650 & $\mathrm{AH}$ & EC & Zhang et al, 2007 \\
\hline 菊科 & Asteraceae & $\begin{array}{l}\text { 合头菊属 } \\
\text { Syncalathium }\end{array}$ & S. kawaguchii (Kitam.) Y. Ling & $\begin{array}{l}\text { 云南德钦白马山 Baima Mt., Deqin, } \\
\text { Yunnan }\end{array}$ & & 16 & 8 & $2 \mathrm{x}$ & 4,260 & $\mathrm{PH}$ & EC & Zhang et al, 2007 \\
\hline 菊科 & Asteraceae & $\begin{array}{l}\text { 合头菊属 } \\
\text { Syncalathium }\end{array}$ & S. kawaguchii (Kitam.) Y. Ling & $\begin{array}{l}\text { 云南巧家药山 Yaoshan, Qiaojia, } \\
\text { Yunnan }\end{array}$ & & 32 & 8 & $4 \mathrm{x}$ & 3,850 & PH & EA & Zhang et al, 2007 \\
\hline 菊科 & Asteraceae & $\begin{array}{l}\text { 合头菊属 } \\
\text { Syncalathium }\end{array}$ & S. pilosum (Y. Ling) C. Shih & $\begin{array}{l}\text { 云南中甸红山 Hong Mt., Zhongdian, } \\
\text { Yunnan }\end{array}$ & & 16 & 8 & $2 \mathrm{x}$ & 4,400 & $\mathrm{PH}$ & $\mathrm{EC}$ & Zhang et al, 2007 \\
\hline 菊科 & Asteraceae & $\begin{array}{l}\text { 合头菊属 } \\
\text { Syncalathium }\end{array}$ & S. souliei (Franch.) Y. Ling & $\begin{array}{l}\text { 西藏南木林秋木乡 Qiumuxiang, } \\
\text { Nanmulin, Tibet }\end{array}$ & & 16 & 8 & $2 \mathrm{x}$ & 4,950 & $\mathrm{PH}$ & EA & Zhang et al, 2007 \\
\hline 菊科 & Asteraceae & $\begin{array}{l}\text { 合头菊属 } \\
\text { Syncalathium }\end{array}$ & S. souliei (Franch.) Y. Ling & $\begin{array}{l}\text { 西藏亚东则里拉山口 Zelila Mt., } \\
\text { Yadong, Tibet }\end{array}$ & & 16 & 8 & $2 \mathrm{x}$ & 4,200 & PH & EA & Zhang et al, 2007 \\
\hline 菊科 & Asteraceae & 蒿属 Artemisia & A. minor Jacq. C. B. Clarke & 云南丽江 Lijiang, Yunnan & & 18 & 9 & $2 \mathrm{x}$ & 3,600 & $\mathrm{PH}$ & NT & 顾志建等, 1993 \\
\hline 菊科 & Asteraceae & 还阳参属 Crepis & C. flexuosa (Ledeb.) C. B. Clarke & 青海玉树 Yushu, Qinghai & & 24 & 12 & $2 \mathrm{x}$ & 4,600 & $\mathrm{PH}$ & EA & 顾志建等, 1993 \\
\hline 菊科 & Asteraceae & $\begin{array}{l}\text { 狗娃花属 } \\
\text { Heteropappus }\end{array}$ & $\begin{array}{l}\text { H. crenatifolius (Hand. -Mazz.) } \\
\text { Griers. }\end{array}$ & 四川红原 Hongyuan, Sichuan & & 18 & 9 & $2 \mathrm{x}$ & 3,540 & $\mathrm{AH}$ & EA & 陈建国等, 2010 \\
\hline 菊科 & Asteraceae & 风毛菊属 Saussurea & S. acroura Cummins & $\begin{array}{l}\text { 甘肃甘南合作 Hezuo, Gannan, } \\
\text { Gansu }\end{array}$ & & 26 & 13 & $2 \mathrm{x}$ & & PH & NT & 李霞, 2014 \\
\hline
\end{tabular}


王家坚, 彭智邦, 孙航, 聂泽龙, 孟盈. 青藏高原与横断山被子植物区系演化的细胞地理学特征. 生物多样性, 2017, 25 (2): 218-225.

http://www.biodiversity-science.net/CN/10.17520/biods.2016281

\begin{tabular}{|c|c|c|c|c|c|c|c|c|c|c|c|}
\hline 科名 Families & 属名 Genera & 种名 Species & 采集地点 Location & $\mathrm{n}$ & $2 n$ & $\mathrm{x}$ & $\begin{array}{l}\text { 倍性 } \\
\text { Ploidy }\end{array}$ & $\begin{array}{l}\text { 海拔 } \\
\text { Altitude } \\
\text { (m) }\end{array}$ & $\begin{array}{l}\text { 生活型 } \\
\text { Life form }\end{array}$ & $\begin{array}{l}\text { 分布型 } \\
\text { Areal-type }\end{array}$ & 参考文献 Reference \\
\hline 菊科 Asteraceae & 风毛菊属 Saussurea & S. brunneopilosa Hand. -Mazz. & 甘肃临潭 Lintan, Gansu & & 30 & 15 & $2 \mathrm{x}$ & 4,000 & $\mathrm{PH}$ & NT & 王一峰等, 2008 \\
\hline 菊科 Asteraceae & 风毛菊属 Saussurea & S. caudata Franch. & 四川九寨沟 Jiuzhaigou, Sichuan & & 30 & 15 & $2 \mathrm{x}$ & 2,413 & $\mathrm{PH}$ & NT & 尚宝龙等, 2014 \\
\hline 菊科 Asteraceae & 风毛菊属 Saussurea & S. ceterach Hand. -Mazz. & 青海囊谦 Nangqian, Qinghai & & 30 & 15 & $2 \mathrm{x}$ & 3,940 & PH & NT & He et al, 2002c \\
\hline 菊科 Asteraceae & 风毛菊属 Saussurea & S. chingiana Hand.-Mazz. & 甘肃夏河 Xiahe, Gansu & & 28 & 14 & $2 \mathrm{x}$ & 3,100 & $\mathrm{PH}$ & NT & 王一峰等, 2010 \\
\hline 菊科 Asteraceae & 风毛菊属 Saussurea & S. columnaris Hand. -Mazz. & 云南香格里拉 Shangri-la, Yunnan & & 32 & 16 & $2 \mathrm{x}$ & 4,436 & PH & NT & 李双智等, 2013 \\
\hline 菊科 Asteraceae & 风毛菊属 Saussurea & S. dschungdienensis Hand. -Mazz. & $\begin{array}{l}\text { 西藏波密嘎龙拉 Galongla, Bomi, } \\
\text { Tibet }\end{array}$ & & 32 & 16 & $2 \mathrm{x}$ & 4,080 & $\mathrm{PH}$ & NT & 陈光富等, 2013 \\
\hline 菊科 Asteraceae & 风毛菊属 Saussurea & S. eopygmaea Hand. -Mazz. & 青海玉树 Yushu, Qinghai & & 30 & 15 & $2 \mathrm{x}$ & 4,060 & $\mathrm{PH}$ & NT & He et al, 2002c \\
\hline 菊科 Asteraceae & 风毛菊属 Saussurea & S. epilobioides Maxim. & 甘肃玛曲 Maqu, Gansu & & 24 & 12 & $2 \mathrm{x}$ & 3,420 & $\mathrm{PH}$ & NT & 王一峰等, 2006 \\
\hline 菊科 Asteraceae & 风毛菊属 Saussurea & S. globosa Chen & $\begin{array}{l}\text { 四川稻城 Daocheng, Sichuan } \\
\text { 青藏高原东缘高寒草甸 Alpine }\end{array}$ & & 34 & 17 & $2 \mathrm{x}$ & 4,039 & $\mathrm{PH}$ & NT & 李双智等, 2013 \\
\hline 菊科 Asteraceae & 风毛菊属 Saussurea & S. globosa Chen. & $\begin{array}{l}\text { meadow in the eastern margin of the } \\
\text { Tibetan Plateau }\end{array}$ & & 32 & 16 & $2 \mathrm{x}$ & 3,500 & PH & NT & 王一峰等, 2007 \\
\hline 菊科 Asteraceae & 风毛菊属 Saussurea & S. gnaphalodes (Royle) Sch. Bip. & $\begin{array}{l}\text { 青海巴颜喀拉山 Bayankala Mt., } \\
\text { Qinghai }\end{array}$ & & c. 21 & 7 & $3 x$ & 5,200 & $\mathrm{PH}$ & C & Huang et al, 1996a \\
\hline 菊科 Asteraceae & 风毛菊属 Saussurea & S. graminea Dunn & 甘肃迭部 Diebu, Gansu & & 28 & 14 & $2 \mathrm{x}$ & 3,930 & $\mathrm{PH}$ & NT & 王一峰等, 2008 \\
\hline 菊科 Asteraceae & 风毛菊属 Saussurea & S. graminea Dunn & 四川甘孜 Ganzi, Sichuan & & 28 & 14 & $2 \mathrm{x}$ & 4,904 & $\mathrm{PH}$ & NT & 李双智等, 2013 \\
\hline 菊科 Asteraceae & 风毛菊属 Saussurea & S. hieracioides Hook. F. & 甘肃玛曲 Maqu, Gansu & & 32 & 16 & $2 \mathrm{x}$ & 3,520 & $\mathrm{PH}$ & NT & 王一峰等, 2006 \\
\hline 菊科 Asteraceae & 风毛菊属 Saussurea & S. hieracioides Hook. F. & $\begin{array}{l}\text { 西藏芒康洛尼 Luoni, Mangkang, } \\
\text { Tibet }\end{array}$ & & 36 & 18 & $2 \mathrm{x}$ & 3,590 & $\mathrm{PH}$ & NT & 陈光富等, 2013 \\
\hline 菊科 Asteraceae & 风毛菊属 Saussurea & S. hieracioides Hook. F. & 四川巴塘 Batang, Sichuan & & 32 & 16 & $2 \mathrm{x}$ & 4,223 & PH & NT & 李双智等, 2013 \\
\hline 菊科 Asteraceae & 风毛菊属 Saussurea & S. iodostegia Hance & $\begin{array}{l}\text { 甘肃甘南曲河沟 Quhegou, Gannan, } \\
\text { Gansu }\end{array}$ & & 32 & 16 & $2 \mathrm{x}$ & 4,000 & $\mathrm{PH}$ & NT & 王一峰等, 2010 \\
\hline
\end{tabular}


王家坚, 彭智邦, 孙航, 聂泽龙, 孟盈. 青藏高原与横断山被子植物区系演化的细胞地理学特征. 生物多样性, 2017, 25 (2): 218-225.

http://www.biodiversity-science.net/CN/10.17520/biods.2016281

\begin{tabular}{|c|c|c|c|c|c|c|c|c|c|c|c|}
\hline 科名 Families & 属名 Genera & 种名 Species & 采集地点 Location & $\mathrm{n}$ & $2 n$ & $\mathrm{x}$ & $\begin{array}{l}\text { 倍性 } \\
\text { Ploidy }\end{array}$ & $\begin{array}{l}\text { 海拔 } \\
\text { Altitude } \\
\text { (m) }\end{array}$ & $\begin{array}{l}\text { 生活型 } \\
\text { Life form }\end{array}$ & $\begin{array}{l}\text { 分布型 } \\
\text { Areal-type }\end{array}$ & 参考文献 Reference \\
\hline 菊科 Asteraceae & 风毛菊属 Saussurea & S. japonica Maxim. & 甘肃迭部 Diebu, Gansu & & 28 & 14 & $2 \mathrm{x}$ & 2,300 & $\mathrm{PH}$ & NT & $\begin{array}{l}\text { 王转莉和王一峰, } \\
2013\end{array}$ \\
\hline 菊科 Asteraceae & 风毛菊属 Saussurea & S. japonica Maxim. & $\begin{array}{l}\text { 甘肃甘南卓尼车巴沟 } \\
\text { Zhuonichebagou, Gannan, Gansu }\end{array}$ & & 28 & 14 & $2 \mathrm{x}$ & 2,700 & $\mathrm{PH}$ & NT & $\begin{array}{l}\text { 王转莉和王一峰, } \\
2013\end{array}$ \\
\hline 菊科 Asteraceae & 风毛菊属 Saussurea & S. japonica Maxim. & $\begin{array}{l}\text { 甘肃甘南卓尼尼巴乡 } \\
\text { Zhuoninibaxiang, Gannan, Gansu }\end{array}$ & & 28 & 14 & $2 \mathrm{x}$ & 3,000 & $\mathrm{PH}$ & NT & $\begin{array}{l}\text { 王转莉和王一峰, } \\
2013\end{array}$ \\
\hline 菊科 Asteraceae & 风毛菊属 Saussurea & S. japonica Maxim. & $\begin{array}{l}\text { 甘肃甘南卓尼旗布寺 } \\
\text { Zhuoniqibuchi, Gannan, Gansu }\end{array}$ & & 28 & 14 & $2 \mathrm{x}$ & 2,550 & $\mathrm{PH}$ & NT & $\begin{array}{l}\text { 王转莉和王一峰, } \\
2013\end{array}$ \\
\hline 菊科 Asteraceae & 风毛菊属 Saussurea & S. Kansuensis Hand. -Mazz. & $\begin{array}{l}\text { 甘肃迭部光盖山 Guanggai Mt., } \\
\text { Diebu, Gansu }\end{array}$ & & 26 & 13 & $2 \mathrm{x}$ & 3,200 & $\mathrm{PH}$ & NT & 高天鹏等, 2009 \\
\hline 菊科 Asteraceae & 风毛菊属 Saussurea & S. katochaete Maxim. & 甘肃玛曲 Maqu, Gansu & & 32 & 16 & $2 \mathrm{x}$ & 4,150 & $\mathrm{PH}$ & NT & 李淮等, 2008 \\
\hline 菊科 Asteraceae & 风毛菊属 Saussurea & S. katochaete Maxim. & 四川白玉 Baiyu, Sichuan & & 32 & 16 & $2 \mathrm{x}$ & 4,437 & $\mathrm{PH}$ & NT & 李双智等, 2013 \\
\hline 菊科 Asteraceae & 风毛菊属 Saussurea & $\begin{array}{l}\text { S. leontodontoides (DC.) Hand. } \\
\text {-Mazz. }\end{array}$ & 西藏芒康 Mangkang, Tibet & & 32 & 16 & $2 \mathrm{x}$ & 4,096 & $\mathrm{PH}$ & NT & 张永增等, 2011 \\
\hline 菊科 Asteraceae & 风毛菊属 Saussurea & S. likiangensis Franch. & $\begin{array}{l}\text { 西藏察隅德姆拉 Chaoudemula, } \\
\text { Tibet }\end{array}$ & & 32 & 16 & $2 x$ & 3,640 & $\mathrm{PH}$ & NT & 陈光富等, 2013 \\
\hline 菊科 Asteraceae & 风毛菊属 Saussurea & S. macrota Franch. & 甘肃卓尼 Zhuoni, Gansu & & 26 & 13 & $2 \mathrm{x}$ & 3,100 & $\mathrm{PH}$ & NT & 高天鹏等, 2009 \\
\hline 菊科 Asteraceae & 风毛菊属 Saussurea & S. medusa Maxim. & 甘肃玛曲 Maqu, Gansu & & 34 & 17 & $2 \mathrm{x}$ & 4,400 & $\mathrm{PH}$ & NT & 王一峰等, 2008 \\
\hline 菊科 Asteraceae & 风毛菊属 Saussurea & S. mongolica (Franch.) Franch. & $\begin{array}{l}\text { 甘肃迭部 Diebu, Gansu } \\
\text { 青藏高原东缘高寒草甸 Alpine }\end{array}$ & & 26 & 13 & $2 \mathrm{x}$ & 3,000 & $\mathrm{PH}$ & NT & 王一峰等, 2008 \\
\hline 菊科 Asteraceae & 风毛菊属 Saussurea & S. nigrescens Maxim. & $\begin{array}{l}\text { meadow in the eastern margin of the } \\
\text { Tibetan Plateau }\end{array}$ & & 32 & 16 & $2 \mathrm{x}$ & 3,500 & $\mathrm{PH}$ & NT & 王一峰等, 2007 \\
\hline 菊科 Asteraceae & 风毛菊属 Saussurea & S. parviflora (Poir.) DC & 甘肃甘南合作 Hezuo, Gannan, & & 26 & 13 & $2 \mathrm{x}$ & & $\mathrm{PH}$ & NT & 李霞, 2014 \\
\hline
\end{tabular}


王家坚, 彭智邦, 孙航, 聂泽龙, 孟盈. 青藏高原与横断山被子植物区系演化的细胞地理学特征. 生物多样性, 2017, 25 (2): 218-225.

http://www.biodiversity-science.net/CN/10.17520/biods.2016281

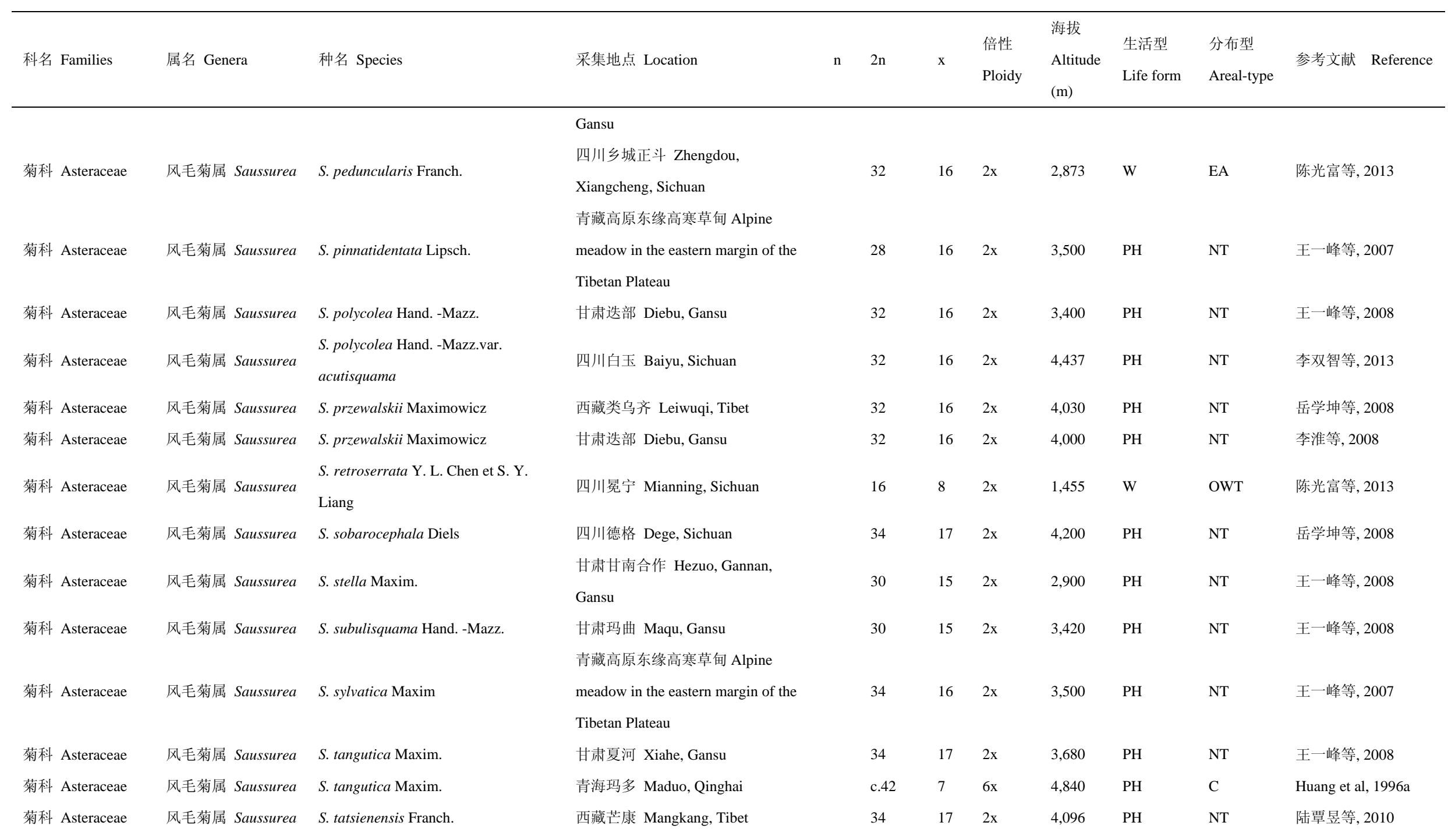


王家坚, 彭智邦, 孙航, 聂泽龙, 孟盈. 青藏高原与横断山被子植物区系演化的细胞地理学特征. 生物多样性, 2017, 25 (2): 218-225.

http://www.biodiversity-science.net/CN/10.17520/biods.2016281

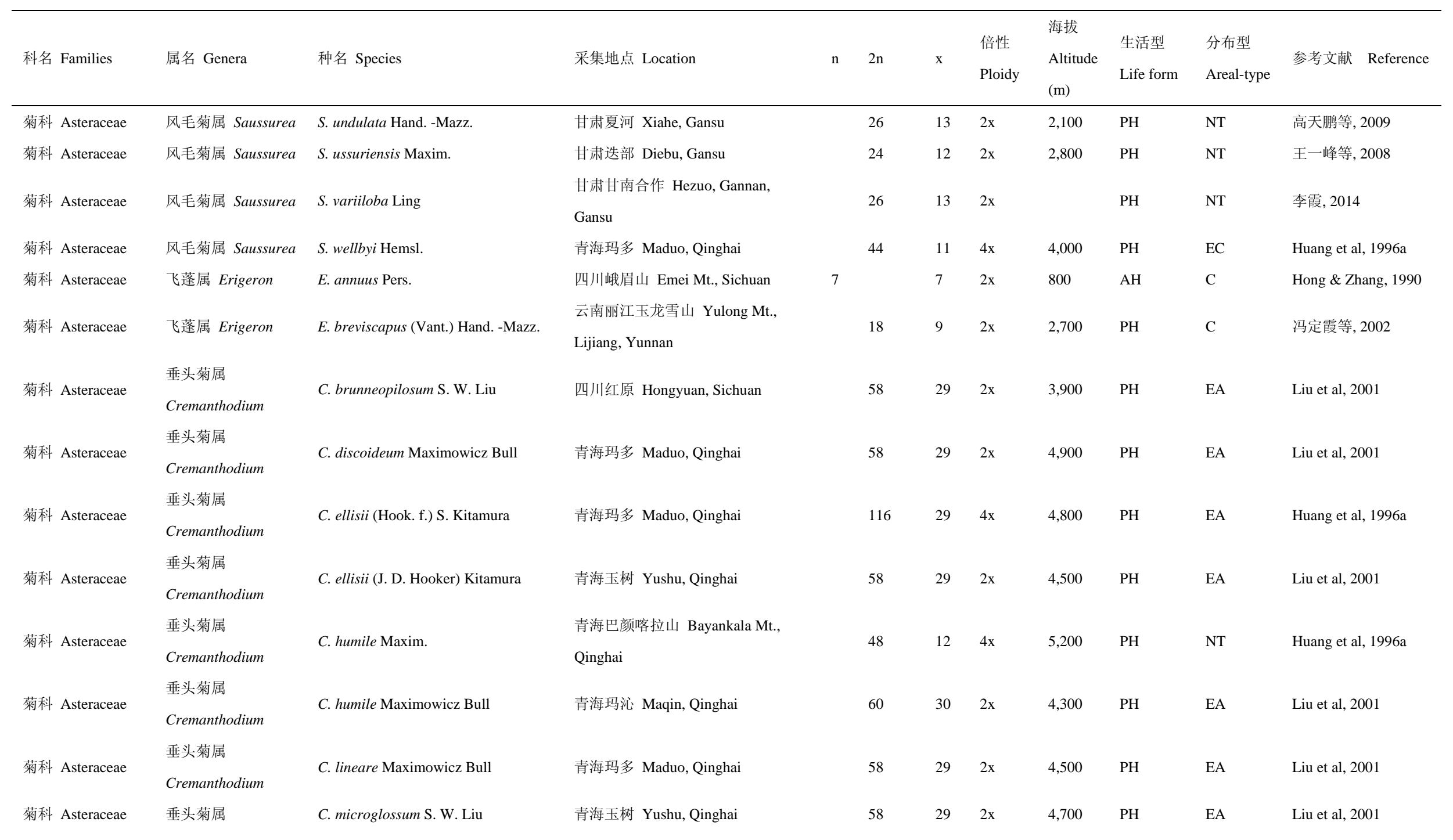


王家坚, 彭智邦, 孙航, 聂泽龙, 孟盈. 青藏高原与横断山被子植物区系演化的细胞地理学特征. 生物多样性, 2017, 25 (2): 218-225.

http://www.biodiversity-science.net/CN/10.17520/biods.2016281

\begin{tabular}{|c|c|c|c|c|c|c|c|c|c|c|c|}
\hline 科名 Families & 属名 Genera & 种名 Species & 采集地点 Location & $\mathrm{n}$ & $2 n$ & $\mathrm{x}$ & $\begin{array}{l}\text { 倍性 } \\
\text { Ploidy }\end{array}$ & $\begin{array}{l}\text { 海拔 } \\
\text { Altitude } \\
\text { (m) }\end{array}$ & $\begin{array}{l}\text { 生活型 } \\
\text { Life form }\end{array}$ & $\begin{array}{l}\text { 分布型 } \\
\text { Areal-type }\end{array}$ & 参考文献 Reference \\
\hline & Cremanthodium & & & & & & & & & & \\
\hline 菊科 Asteraceae & $\begin{array}{l}\text { 垂头菊属 } \\
\text { Cremanthodium }\end{array}$ & C. stenoglossum Y. Ling \& S. W. Liu & 青海玛多 Maduo, Qinghai & & 58 & 29 & $2 \mathrm{x}$ & 5,000 & $\mathrm{PH}$ & EA & Liu et al, 2001 \\
\hline 菊科 Asteraceae & 帚菊属 Pertya & $\begin{array}{l}\text { P. berberidoides (Handel-Mazzetti) } \\
\text { Y. C. Tseng }\end{array}$ & 四川巴塘 Batang, Sichuan & & 64 & 16 & $4 \mathrm{x}$ & 3,978 & PH & NT & 陈光富等, 2013 \\
\hline 菊科 Asteraceae & 莴苣属 Lactuca & L. indica (L.) Shih & 四川泸州 Luzhou, Sichuan & & 18 & 9 & $2 \mathrm{x}$ & & $\mathrm{PH}$ & OWT & 蔡仕钜等, 2011 \\
\hline $\begin{array}{l}\text { 苦菅苔科 } \\
\text { Gesneriaceae }\end{array}$ & $\begin{array}{l}\text { 直瓣菅苔属 } \\
\text { Ancylostemon }\end{array}$ & A. aureus (Franch.) B. L. Burtt & 云南宾川 Binchuan, Yunnan & & 34 & 17 & $2 \mathrm{x}$ & & $\mathrm{PH}$ & EC & $\begin{array}{l}\text { 王印政和顾志建, } \\
1999\end{array}$ \\
\hline $\begin{array}{l}\text { 苦芭苔科 } \\
\text { Gesneriaceae }\end{array}$ & $\begin{array}{l}\text { 珊瑚亘苔属 } \\
\text { Corallodiscus }\end{array}$ & C. flabellatus (Craib) B. L. Burtt & 云南中甸 Zhongdian, Yunnan & & 40 & 10 & $4 \mathrm{x}$ & & $\mathrm{PH}$ & EA & 鲁元学等, 2002b \\
\hline $\begin{array}{l}\text { 昆栏树科 } \\
\text { Trochodendraceae }\end{array}$ & $\begin{array}{l}\text { 水青树属 } \\
\text { Tetracentron }\end{array}$ & T. sinense Oliver & 云南贡山 Gongshan, Yunnan & & 38 & 19 & $2 \mathrm{x}$ & & $\mathrm{W}$ & EA & Xue et al, 2008 \\
\hline 兰科 Orchidaceae & $\begin{array}{l}\text { 紫斑兰属 } \\
\text { Hemipiliopsis }\end{array}$ & $\begin{array}{l}\text { H. purpureopunctata (K. Y. Lang) Y. } \\
\text { B. Luo and S. C. Chen }\end{array}$ & 西藏林芝 Linzhi, Tibet & & 42 & 21 & $2 \mathrm{x}$ & 2,550 & PH & EC & Luo, 2004 \\
\hline 兰科 Orchidaceae & $\begin{array}{l}\text { 玉凤花属 } \\
\text { Habenaria }\end{array}$ & $\begin{array}{l}\text { H. aitchisonii Rchb. f. ex Aitch. \& } \\
\text { Hemsl. }\end{array}$ & 云南鹤庆 Heqing, Yunnan & & 32 & 16 & $2 \mathrm{x}$ & 2,300 & PH & NT & Luo, 2004 \\
\hline 兰科 Orchidaceae & $\begin{array}{l}\text { 玉凤花属 } \\
\text { Habenaria }\end{array}$ & $\begin{array}{l}\text { H. aitchisonii Rchb. f. ex Aitch. \& } \\
\text { Hemsl. }\end{array}$ & 云南中甸 Zhongdian, Yunnan & & 64 & 16 & $4 \mathrm{x}$ & 2,550 & $\mathrm{PH}$ & NT & Luo, 2004 \\
\hline 兰科 Orchidaceae & $\begin{array}{l}\text { 玉凤花属 } \\
\text { Habenaria }\end{array}$ & H. delavayi Finet Rev. Gén & 西藏林芝 Linzhi, Tibet & & 42 & 21 & $2 \mathrm{x}$ & 2,700 & $\mathrm{PH}$ & NT & Luo, 2004 \\
\hline 兰科 Orchidaceae & $\begin{array}{l}\text { 玉凤花属 } \\
\text { Habenaria }\end{array}$ & H. mairei Schlechter Repert & 云南中甸 Zhongdian, Yunnan & & 40 & 20 & $2 \mathrm{x}$ & 2,540 & $\mathrm{PH}$ & NT & Luo, 2004 \\
\hline 兰科 Orchidaceae & 小红门兰属 & P. chusua (D. Don) Soó & 云南丽江 Lijiang, Yunnan & & c.98 & 21 & $4 \mathrm{x}$ & 3,400 & $\mathrm{PH}$ & NT & Luo, 2004 \\
\hline
\end{tabular}


王家坚, 彭智邦, 孙航, 聂泽龙, 孟盈. 青藏高原与横断山被子植物区系演化的细胞地理学特征. 生物多样性, 2017, 25 (2): 218-225.

http://www.biodiversity-science.net/CN/10.17520/biods.2016281

\begin{tabular}{|c|c|c|c|c|c|c|c|c|c|c|c|c|}
\hline 科名 & Families & 属名 Genera & 种名 Species & 采集地点 Location & $\mathrm{n}$ & $2 \mathrm{n}$ & $\mathrm{x}$ & $\begin{array}{l}\text { 倍性 } \\
\text { Ploidy }\end{array}$ & $\begin{array}{l}\text { 海拔 } \\
\text { Altitude } \\
\text { (m) }\end{array}$ & $\begin{array}{l}\text { 生活型 } \\
\text { Life form }\end{array}$ & $\begin{array}{l}\text { 分布型 } \\
\text { Areal-type }\end{array}$ & 参考文献 Reference \\
\hline & & Ponerorchis & & & & & & & & & & \\
\hline 兰科 & Orchidaceae & $\begin{array}{l}\text { 小红门兰属 } \\
\text { Ponerorchis }\end{array}$ & P. chusua (D. Don) Soó & 云南维西 Weixi, Yunnan & & 42 & 21 & $2 \mathrm{x}$ & 2,630 & $\mathrm{PH}$ & NT & Luo, 2004 \\
\hline 兰科 & Orchidaceae & $\begin{array}{l}\text { 小红门兰属 } \\
\text { Ponerorchis }\end{array}$ & P. chusua (D. Don) Soó & 云南维西 Weixi, Yunnan & & 42 & 21 & $2 \mathrm{x}$ & 3,300 & PH & NT & Luo, 2004 \\
\hline 兰科 & Orchidaceae & $\begin{array}{l}\text { 小红门兰属 } \\
\text { Ponerorchis }\end{array}$ & P. chusua (D. Don) Soó & 云南中甸 Zhongdian, Yunnan & & 42 & 21 & $2 \mathrm{x}$ & 2,700 & $\mathrm{PH}$ & NT & Luo, 2004 \\
\hline 兰科 & Orchidaceae & $\begin{array}{l}\text { 小红门兰属 } \\
\text { Ponerorchis }\end{array}$ & P. chusua (D. Don) Soó & 云南中甸 Zhongdian, Yunnan & & 63 & 21 & $3 \mathrm{x}$ & 3,600 & $\mathrm{PH}$ & NT & Luo, 2004 \\
\hline 兰科 & Orchidaceae & 舌潒兰属 Hemipilia & H. cruciata Finet & 云南丽江 Lijiang, Yunnan & & 42 & 21 & $2 \mathrm{x}$ & 2,450 & $\mathrm{PH}$ & EA & Luo, 2004 \\
\hline 兰科 & Orchidaceae & 舌㖨兰属 Hemipilia & H. cruciata Finet & 云南丽江 Lijiang, Yunnan & & 42 & 21 & $2 \mathrm{x}$ & 2,520 & $\mathrm{PH}$ & EA & Luo, 2004 \\
\hline 兰科 & Orchidaceae & 舌嚎兰属 Hemipilia & H. cruciata Finet & 云南丽江 Lijiang, Yunnan & & 42 & 21 & $2 \mathrm{x}$ & 2,620 & $\mathrm{PH}$ & EA & Luo, 2004 \\
\hline 兰科 & Orchidaceae & 舌㗒兰属 Hemipilia & H. cruciata Finet & 云南丽江 Lijiang, Yunnan & & 42 & 21 & $2 \mathrm{x}$ & 2,700 & $\mathrm{PH}$ & EA & Luo, 2004 \\
\hline 兰科 & Orchidaceae & 舌㗓兰属 Hemipilia & H. cruciata Finet & 云南丽江 Lijiang, Yunnan & & 42 & 21 & $2 \mathrm{x}$ & 2,780 & $\mathrm{PH}$ & EA & Luo, 2004 \\
\hline 兰科 & Orchidaceae & 舌呦兰属 Hemipilia & H. flabellata Bureau \& Franch. & 云南中甸 Zhongdian, Yunnan & & 42 & 21 & $2 \mathrm{x}$ & 2,810 & $\mathrm{PH}$ & EA & Luo, 2004 \\
\hline 兰科 & Orchidaceae & 舌㗒兰属 Hemipilia & H. flabellata Bureau \& Franch. & 云南鹤庆 Heqing, Yunnan & & 42 & 21 & $2 \mathrm{x}$ & 2,100 & PH & EA & Luo, 2004 \\
\hline 兰科 & Orchidaceae & 兰属 Cymbidium & C. eburneum Lindley & 云南保山 Baoshan, Yunnan & & 40 & 10 & $4 \mathrm{x}$ & & $\mathrm{PH}$ & $\mathrm{TA} \& \mathrm{TA}$ & 李玉阁等, 2003 \\
\hline 兰科 & Orchidaceae & 兰属 Cymbidium & $\begin{array}{l}\text { C. hookerianum H. G. Reichenbach } \\
\text { Gard. }\end{array}$ & 云南腾冲 Tengchong, Yunnan & & 40 & 10 & $4 \mathrm{x}$ & & $\mathrm{PH}$ & TA \& TA & 李玉阁等, 2004 \\
\hline 兰科 & Orchidaceae & 阔荵兰属 Peristylus & P. coeloceras Finet Rev. Gén & 云南丽江 Lijiang, Yunnan & & 42 & 21 & $2 \mathrm{x}$ & 2,720 & $\mathrm{PH}$ & TA \& TA & Luo, 2004 \\
\hline 兰科 & Orchidaceae & 灰花兰属 Galearis & G. diantha (Schltr.) P. F. Hunt & 云南中甸 Zhongdian, Yunnan & & 42 & 21 & $2 \mathrm{x}$ & 3,660 & $\mathrm{PH}$ & $\begin{array}{l}\text { EA \& } \\
\text { NAD }\end{array}$ & Luo, 2004 \\
\hline 兰科 & Orchidaceae & 红门兰属 Orchis & O. brevicalcarata (Finet) P. F. Hunt & 云南中甸 Zhongdian, Yunnan & & 42 & 21 & $2 \mathrm{x}$ & 3,200 & PH & NT & Luo, 2004 \\
\hline
\end{tabular}


王家坚, 彭智邦, 孙航, 聂泽龙, 孟盈. 青藏高原与横断山被子植物区系演化的细胞地理学特征. 生物多样性, 2017, 25 (2): 218-225.

http://www.biodiversity-science.net/CN/10.17520/biods.2016281

\begin{tabular}{|c|c|c|c|c|c|c|c|c|c|c|c|}
\hline 科名 Families & 属名 Genera & 种名 Species & 采集地点 Location & $\mathrm{n}$ & $2 \mathrm{n}$ & $\mathrm{x}$ & $\begin{array}{l}\text { 倍性 } \\
\text { Ploidy }\end{array}$ & $\begin{array}{l}\text { 海拔 } \\
\text { Altitude } \\
\text { (m) }\end{array}$ & $\begin{array}{l}\text { 生活型 } \\
\text { Life form }\end{array}$ & $\begin{array}{l}\text { 分布型 } \\
\text { Areal-type }\end{array}$ & 参考文献 Reference \\
\hline 兰科 Orchidaceae & 独蒜兰属 Pleione & P. bulbocodioides & 云南 Yunnan & & 120 & 20 & $6 \mathrm{x}$ & & $\mathrm{AH}$ & TA & Stergianou 1989 \\
\hline 兰科 Orchidaceae & 独赫兰属 Pleione & P. hookeriana (Lindl.) B.S. Williams & $\begin{array}{l}\text { Bhutan; Burma; NE. India; E. Nepal; } \\
\text { Tibet, China }\end{array}$ & & 40 & 20 & $2 \mathrm{x}$ & & АН & TA & Stergianou 1989 \\
\hline 兰科 Orchidaceae & 独蒜兰属 Pleione & P. limprichtii Pink & $\begin{array}{l}\text { Records are not clear (Sichuan or } \\
\text { Burma) }\end{array}$ & & 40 & 20 & $2 \mathrm{x}$ & & АН & $\mathrm{TA}$ & Stergianou 1989 \\
\hline 兰科 Orchidaceae & 独蒜兰属 Pleione & p. $x$ confusa P. J. Cribb \& C. Z. Tang & N. Burma & & 40 & 20 & $2 \mathrm{x}$ & & $\mathrm{AH}$ & $\mathrm{TA}$ & Stergianou 1989 \\
\hline 兰科 Orchidaceae & 独蒜兰属 Pleione & P. yunnanensis (Rolfe) Rolfe & N. Burma; Yunnan , Sichuan, China & & 40 & 20 & $2 \mathrm{x}$ & & АH & $\mathrm{TA}$ & Stergianou 1989 \\
\hline 兰科 Orchidaceae & 独活属 Heracleum & H. lanceum (Thunb.) Vujik & 云南维西 Weixi, Yunnan & & 72 & 18 & $4 \mathrm{x}$ & 2,630 & PH & OWT & Luo, 2004 \\
\hline 兰科 Orchidaceae & 独活属 Heracleum & H. monorchis (Linnaeus) R. Brown & 云南中甸 Zhongdian, Yunnan & & 38 & 19 & $2 \mathrm{x}$ & 3,000 & PH & OWT & Luo, 2004 \\
\hline 兰科 Orchidaceae & $\begin{array}{l}\text { 槽舌兰属 } \\
\text { Holcoglossum }\end{array}$ & H. rupestre (Hand. -Mazz.) Garay & 云南中甸 Zhongdian, Yunnan & & 38 & 19 & $2 \mathrm{x}$ & & $\mathrm{PH}$ & EA & 景望春等, 2007 \\
\hline 兰科 Orchidaceae & $\begin{array}{l}\text { 槽舌兰属 } \\
\text { Holcoglossum }\end{array}$ & H. sinicum Christenson & 云南宾川 Binchuan, Yunnan & & 38 & 19 & $2 \mathrm{x}$ & & PH & EA & 景望春等, 2007 \\
\hline 兰科 Orchidaceae & $\begin{array}{l}\text { 槽舌兰属 } \\
\text { Holcoglossum }\end{array}$ & H. weixiense X. H. Jin \& S. C. Chen & 云南维西 Weixi, Yunnan & & 38 & 19 & $2 \mathrm{x}$ & & PH & EA & 景望春等, 2007 \\
\hline 荟科 & 菾麦属 Fagopyrum & F. crispatifolium J. L. Liu & 四川凉山州普格县螺髧山镇 Puge, & & 32 & 8 & $4 \mathrm{x}$ & 1,900 & PH & OWT & 刘建林等, 2009 \\
\hline
\end{tabular}


王家坚, 彭智邦, 孙航, 聂泽龙, 孟盈. 青藏高原与横断山被子植物区系演化的细胞地理学特征. 生物多样性, 2017, 25 (2): 218-225.

http://www.biodiversity-science.net/CN/10.17520/biods.2016281

\begin{tabular}{|c|c|c|c|c|c|c|c|c|c|c|c|}
\hline 科名 Families & 属名 Genera & 种名 Species & 采集地点 Location & $\mathrm{n}$ & $2 \mathrm{n}$ & $\mathrm{x}$ & $\begin{array}{l}\text { 倍性 } \\
\text { Ploidy }\end{array}$ & $\begin{array}{l}\text { 海拔 } \\
\text { Altitude } \\
\text { (m) }\end{array}$ & $\begin{array}{l}\text { 生活型 } \\
\text { Life form }\end{array}$ & $\begin{array}{l}\text { 分布型 } \\
\text { Areal-type }\end{array}$ & 参考文献 Reference \\
\hline Polygonaceae & & & Liangshan, Sichuan & & & & & & & & \\
\hline $\begin{array}{l}\text { 䓹科 } \\
\text { Polygonaceae }\end{array}$ & 养麦属 Fagopyrum & F. qiangcai D. Q. Bai & 四川理县 Lixian County, Sichuan & & 16 & 8 & $2 \mathrm{x}$ & 1,190 & $\mathrm{AH}$ & OWT & Shao et al, 2011 \\
\hline $\begin{array}{l}\text { 軨科 } \\
\text { Polygonaceae }\end{array}$ & 大黄属 Rheum & R. alexandrae Batal. & 西藏达日 Dari, Tibet & & 44 & 22 & $2 \mathrm{x}$ & & $\mathrm{PH}$ & TA & 刘瑞瑞, 2010 \\
\hline $\begin{array}{l}\text { 䓹科 } \\
\text { Polygonaceae }\end{array}$ & 大黄属 Rheum & R. likiangense Sam. & 云南丽江 Lijiang, Yunnan & & 44 & 22 & $2 \mathrm{x}$ & & PH & TA & 刘瑞瑞, 2010 \\
\hline $\begin{array}{l}\text { 蓼科 } \\
\text { Polygonaceae }\end{array}$ & 大黄属 Rheum & R. reticulatum A. Los. & 青海玛多 Maduo, Qinghai & & 44 & 22 & $2 \mathrm{x}$ & & $\mathrm{PH}$ & TA & 刘瑞瑞, 2010 \\
\hline $\begin{array}{l}\text { 䓹科 } \\
\text { Polygonaceae }\end{array}$ & 大黄属 Rheum & R. tanguticum Maxim. ex Balf. & 青海达卡 Daka, Qinghai & & 22 & 11 & $2 \mathrm{x}$ & 3,973 & PH & TA & 胡延萍等, 2007 \\
\hline $\begin{array}{l}\text { 蔘科 } \\
\text { Polygonaceae }\end{array}$ & 大黄属 Rheum & R. tanguticum Maxim. ex Balf. & 青海大武 Dawu, Qinghai & & 22 & 11 & $2 \mathrm{x}$ & 3,960 & PH & TA & 胡延萍等, 2007 \\
\hline $\begin{array}{l}\text { 苶科 } \\
\text { Polygonaceae }\end{array}$ & 大黄属 Rheum & R. tanguticum Maxim. ex Balf. & 青海吉卡 Jika, Qinghai & & 22 & 11 & $2 \mathrm{x}$ & 4,018 & PH & TA & 胡延萍等, 2007 \\
\hline $\begin{array}{l}\text { 蔘科 } \\
\text { Polygonaceae }\end{array}$ & 大黄属 Rheum & R. tanguticum Maxim. ex Balf. & 青海柯曲 Kequ, Qinghai & & 22 & 11 & $2 \mathrm{x}$ & 4,021 & PH & TA & 胡延萍等, 2007 \\
\hline
\end{tabular}


王家坚, 彭智邦, 孙航, 聂泽龙, 孟盈. 青藏高原与横断山被子植物区系演化的细胞地理学特征. 生物多样性, 2017, 25 (2): 218-225.

http://www.biodiversity-science.net/CN/10.17520/biods.2016281

\begin{tabular}{|c|c|c|c|c|c|c|c|c|c|c|c|c|}
\hline 科名 Families & 属名 Genera & 种名 Species & 采集地点 & Location & $\mathrm{n}$ & $2 \mathrm{n}$ & $\mathrm{x}$ & $\begin{array}{l}\text { 倍性 } \\
\text { Ploidy }\end{array}$ & $\begin{array}{l}\text { 海拔 } \\
\text { Altitude } \\
\text { (m) }\end{array}$ & $\begin{array}{l}\text { 生活型 } \\
\text { Life form }\end{array}$ & $\begin{array}{l}\text { 分布型 } \\
\text { Areal-type }\end{array}$ & 参考文献 Reference \\
\hline $\begin{array}{l}\text { 蓼科 } \\
\text { Polygonaceae }\end{array}$ & 大黄属 Rheum & R. tanguticum Maxim. ex Balf. & 四川松潘 & Songpan, Sichuan & & 22 & 11 & $2 \mathrm{x}$ & 3,413 & $\mathrm{PH}$ & $\mathrm{TA}$ & 胡延萍等, 2007 \\
\hline $\begin{array}{l}\text { 蓼科 } \\
\text { Polygonaceae }\end{array}$ & 大黄属 Rheum & R. tanguticum Maxim. ex Balf. & 青海果洛 & Guoluo, Qinghai & & 44 & 22 & $2 \mathrm{x}$ & & $\mathrm{PH}$ & $\mathrm{TA}$ & 刘瑞瑞, 2010 \\
\hline $\begin{array}{l}\text { 蔘科 } \\
\text { Polygonaceae }\end{array}$ & 大黄属 Rheum & R. webbianum Royle & 青海乐都 & Ledu, Qinghai & & 44 & 22 & $2 \mathrm{x}$ & & $\mathrm{PH}$ & $\mathrm{TA}$ & 刘瑞瑞, 2010 \\
\hline $\begin{array}{l}\text { 苶科 } \\
\text { Polygonaceae }\end{array}$ & 大黄属 Rheum & R. wittrockii Lundstr. & 新疆伊犁 & Ili, Xinjiang & & 44 & 11 & $4 \mathrm{x}$ & & $\mathrm{PH}$ & TA & 刘瑞瑞, 2010 \\
\hline $\begin{array}{l}\text { 列当科 } \\
\text { Elaeagnaceae }\end{array}$ & 沙棘属 Hippophae & H. neurocarpa S. W. Liu \& T. N. He & 四川稻城 & Daocheng, Sichuan & & 24 & 12 & $2 \mathrm{x}$ & & $\mathrm{W}$ & OWT & Cao and Lu, 1989 \\
\hline $\begin{array}{l}\text { 列当科 } \\
\text { Elaeagnaceae }\end{array}$ & 沙棘属 Hippophae & $\begin{array}{l}\text { H. rhamnoides L. subsp. sinensis } \\
\text { Rousi }\end{array}$ & 四川南坪 & Nanping, Sichuan & & 24 & 12 & $2 \mathrm{x}$ & & $\mathrm{W}$ & OWT & Cao and Lu, 1989 \\
\hline $\begin{array}{l}\text { 列当科 } \\
\text { Elaeagnaceae }\end{array}$ & 沙棘属 Hippophae & $\begin{array}{l}\text { H. rhamnoides L. subsp. yunnanensis } \\
\text { Rousi }\end{array}$ & 云南中甸 & Zhongdian, Yunnan & & 24 & 12 & $2 \mathrm{x}$ & & $\mathrm{W}$ & OWT & Cao and Lu, 1989 \\
\hline $\begin{array}{l}\text { 列当科 } \\
\text { Elaeagnaceae }\end{array}$ & 沙棘属 Hippophae & H. tibetana Schlecht. & 四川红原 & Hongyuan, Sichuan & & 24 & 12 & $2 \mathrm{x}$ & & $\mathrm{W}$ & OWT & Cao and Lu, 1989 \\
\hline $\begin{array}{l}\text { 列当科 } \\
\text { Orobanchaceae }\end{array}$ & $\begin{array}{l}\text { 马先蒿属 } \\
\text { Pedicularis }\end{array}$ & P. densispica Franch. ex Maxim. & 云南中甸 & Zhongdian, Yunnan & & 16 & 8 & $2 \mathrm{x}$ & & $\mathrm{PH}$ & NT & Cai et al, 2004 \\
\hline $\begin{array}{l}\text { 列当科 } \\
\text { Orobanchaceae }\end{array}$ & $\begin{array}{l}\text { 马先蒿属 } \\
\text { Pedicularis }\end{array}$ & P. dichotoma Bonati & 云南中甸 & Zhongdian, Yunnan & & 16 & 8 & $2 \mathrm{x}$ & & $\mathrm{PH}$ & NT & Cai et al, 2004 \\
\hline $\begin{array}{l}\text { 列当科 } \\
\text { Orobanchaceae }\end{array}$ & $\begin{array}{l}\text { 马先蒿属 } \\
\text { Pedicularis }\end{array}$ & P. dolichocymba Hand. -Mazz. & 云南中甸 & Zhongdian, Yunnan & & 16 & 8 & $2 \mathrm{x}$ & & $\mathrm{PH}$ & NT & Cai et al, 2004 \\
\hline 列当科 & 马先蒿属 & P. dunniana Bonati & 云南香格 & 里拉 Shangri-La, Yunnan & & 16 & 8 & $2 \mathrm{x}$ & & $\mathrm{PH}$ & NT & Cai et al, 2004 \\
\hline
\end{tabular}


王家坚, 彭智邦, 孙航, 聂泽龙, 孟盈. 青藏高原与横断山被子植物区系演化的细胞地理学特征. 生物多样性, 2017, 25 (2): 218-225.

http://www.biodiversity-science.net/CN/10.17520/biods.2016281

\begin{tabular}{|c|c|c|c|c|c|c|c|c|c|c|c|}
\hline 科名 Families & 属名 Genera & 种名 Species & 采集地点 Location & $\mathrm{n}$ & $2 \mathrm{n}$ & $\mathrm{x}$ & $\begin{array}{l}\text { 倍性 } \\
\text { Ploidy }\end{array}$ & $\begin{array}{l}\text { 海拔 } \\
\text { Altitude } \\
\text { (m) }\end{array}$ & $\begin{array}{l}\text { 生活型 } \\
\text { Life form }\end{array}$ & $\begin{array}{l}\text { 分布型 } \\
\text { Areal-type }\end{array}$ & 参考文献 Reference \\
\hline Orobanchaceae & Pedicularis & & & & & & & & & & \\
\hline $\begin{array}{l}\text { 列当科 } \\
\text { Orobanchaceae }\end{array}$ & $\begin{array}{l}\text { 马先蒿属 } \\
\text { Pedicularis }\end{array}$ & $\begin{array}{l}\text { P. kansuensis subsp. kansuensis forma } \\
\text { kansuensis }\end{array}$ & 青海互助 Huzhu, Qinghai & & 16 & 8 & $2 \mathrm{x}$ & 2,300 & $\mathrm{AH}$ & NT & 黄荣福等, 1996 \\
\hline $\begin{array}{l}\text { 列当科 } \\
\text { Orobanchaceae }\end{array}$ & $\begin{array}{l}\text { 马先蒿属 } \\
\text { Pedicularis }\end{array}$ & P. muscicola Maxim. & 青海互助 Huzhu, Qinghai & & 16 & 8 & $2 \mathrm{x}$ & 2,100 & $\mathrm{PH}$ & NT & 黄荣福等, 1996 \\
\hline $\begin{array}{l}\text { 列当科 } \\
\text { Orobanchaceae }\end{array}$ & $\begin{array}{l}\text { 马先蒿属 } \\
\text { Pedicularis }\end{array}$ & $\begin{array}{l}\text { P. obliquigaleata W. B. Yu \& H. } \\
\text { Wang }\end{array}$ & $\begin{array}{l}\text { 云南香格里拉大雪山 Snow Mt., } \\
\text { Shangri-la, Yunnan }\end{array}$ & & 16 & 8 & $2 \mathrm{x}$ & 4,294 & $\mathrm{PH}$ & NT & Yu et al, 2010 \\
\hline $\begin{array}{l}\text { 列当科 } \\
\text { Orobanchaceae }\end{array}$ & $\begin{array}{l}\text { 马先蒿属 } \\
\text { Pedicularis }\end{array}$ & $\begin{array}{l}\text { P. oederi Vahl. var. sinensis (Maxim.) } \\
\text { Hurus. }\end{array}$ & $\begin{array}{l}\text { 青海贵德县拉脊山 Laji Mt., Guide, } \\
\text { Gansu }\end{array}$ & & 16 & 8 & $2 \mathrm{x}$ & 3,850 & $\mathrm{PH}$ & NT & 黄荣福等, 1996 \\
\hline $\begin{array}{l}\text { 列当科 } \\
\text { Orobanchaceae }\end{array}$ & $\begin{array}{l}\text { 马先蒿属 } \\
\text { Pedicularis }\end{array}$ & P. pilostachya Maxin. & $\begin{array}{l}\text { 青海祁连县托勒山 Tulai Mt., } \\
\text { Qinghai }\end{array}$ & & 16 & 8 & $2 \mathrm{x}$ & 4,200 & $\mathrm{PH}$ & NT & 黄荣福等, 1996 \\
\hline $\begin{array}{l}\text { 列当科 } \\
\text { Orobanchaceae }\end{array}$ & $\begin{array}{l}\text { 马先蒿属 } \\
\text { Pedicularis }\end{array}$ & P. przewalskii Maxim. & $\begin{array}{l}\text { 青海兴海县鸡拉山 Ela Mt., Xinghai, } \\
\text { Qinghai }\end{array}$ & & 16 & 8 & $2 \mathrm{x}$ & 4,050 & $\mathrm{PH}$ & NT & 黄荣福等, 1996 \\
\hline $\begin{array}{l}\text { 列当科 } \\
\text { Orobanchaceae }\end{array}$ & $\begin{array}{l}\text { 马先蒿属 } \\
\text { Pedicularis }\end{array}$ & P. rex C. B. Clarke ex Maxim. & 云南中甸 Zhongdian, Yunnan & & 16 & 8 & $2 \mathrm{x}$ & & $\mathrm{PH}$ & NT & Cai et al, 2004 \\
\hline $\begin{array}{l}\text { 列当科 } \\
\text { Orobanchaceae }\end{array}$ & $\begin{array}{l}\text { 马先蒿属 } \\
\text { Pedicularis }\end{array}$ & P. rhodotricha Maxim. & 云南德钦 Deqin, Yunnan & & 16 & 8 & $2 \mathrm{x}$ & & $\mathrm{PH}$ & NT & Cai et al, 2004 \\
\hline
\end{tabular}


王家坚, 彭智邦, 孙航, 聂泽龙, 孟盈. 青藏高原与横断山被子植物区系演化的细胞地理学特征. 生物多样性, 2017, 25 (2): 218-225.

http://www.biodiversity-science.net/CN/10.17520/biods.2016281

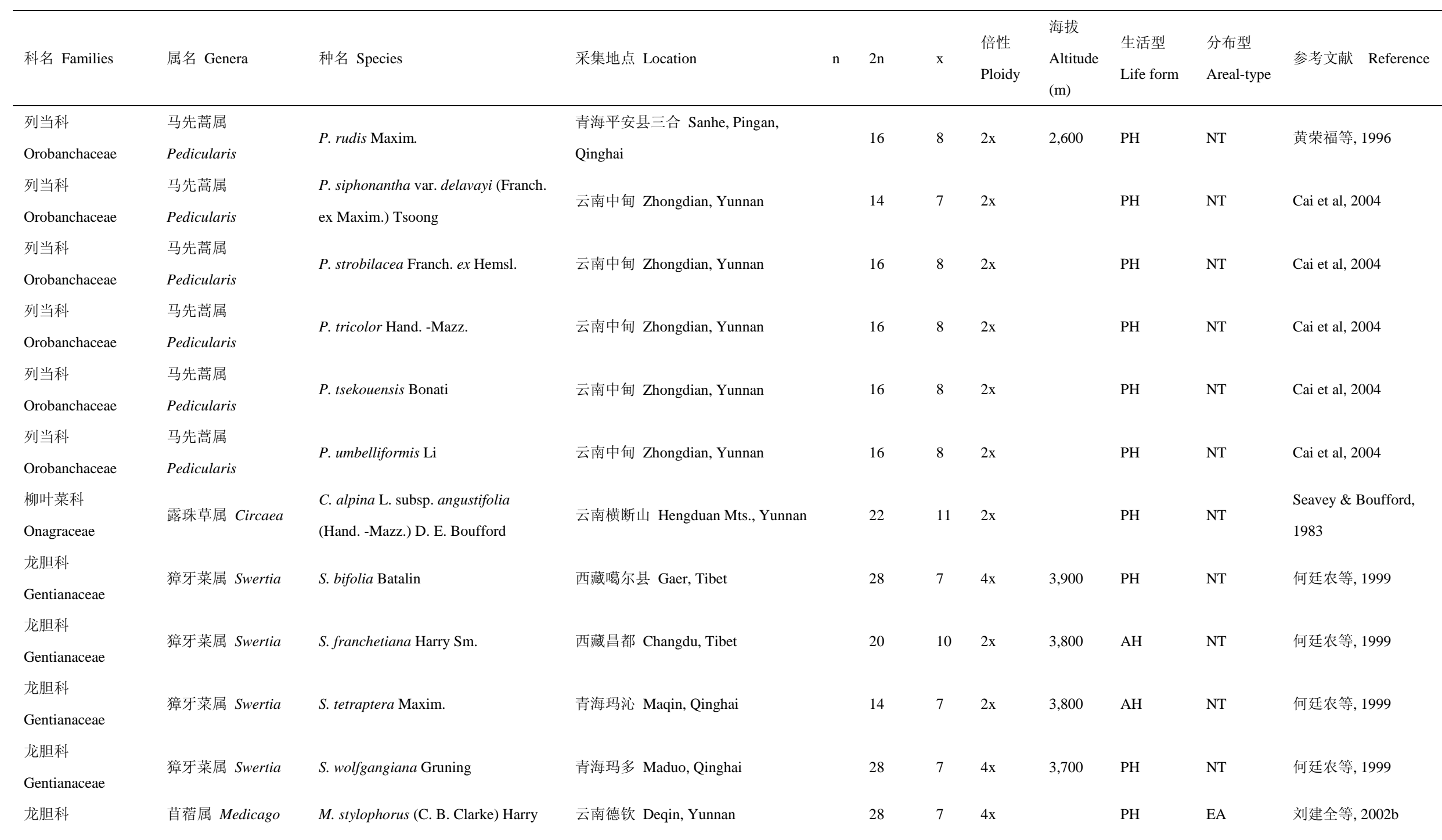


王家坚, 彭智邦, 孙航, 聂泽龙, 孟盈. 青藏高原与横断山被子植物区系演化的细胞地理学特征. 生物多样性, 2017, 25 (2): 218-225.

http://www.biodiversity-science.net/CN/10.17520/biods.2016281

\begin{tabular}{|c|c|c|c|c|c|c|c|c|c|c|c|}
\hline 科名 Families & 属名 Genera & 种名 Species & 采集地点 Location & $\mathrm{n}$ & $2 n$ & $\mathrm{x}$ & $\begin{array}{l}\text { 倍性 } \\
\text { Ploidy }\end{array}$ & $\begin{array}{l}\text { 海拔 } \\
\text { Altitude } \\
\text { (m) }\end{array}$ & $\begin{array}{l}\text { 生活型 } \\
\text { Life form }\end{array}$ & $\begin{array}{l}\text { 分布型 } \\
\text { Areal-type }\end{array}$ & 参考文献 Reference \\
\hline Gentianaceae & & Smith & & & & & & & & & \\
\hline $\begin{array}{l}\text { 龙胆科 } \\
\text { Gentianaceae }\end{array}$ & 龙胆属 Gentiana & G. alsinoides Franch. & 云南丽江 Lijiang, Yunnan & & 20 & 10 & $2 x$ & 2,950 & $\mathrm{AH}$ & C & Küpfer \& Yuan, 1996 \\
\hline $\begin{array}{l}\text { 龙胆科 } \\
\text { Gentianaceae }\end{array}$ & 龙胆属 Gentiana & G. altorum Harry Smith & 四川康定 Kangding, Sichuan & & 24 & 12 & $2 \mathrm{x}$ & 3,600 & PH & C & 刘建全等, 2002a \\
\hline $\begin{array}{l}\text { 龙胆科 } \\
\text { Gentianaceae }\end{array}$ & 龙胆属 Gentiana & G. ampla Harry Sm. & 云南丽江 Lijiang, Yunnan & & 48 & 12 & $4 \mathrm{x}$ & 3,700 & PH & $\mathrm{C}$ & 陈世龙等, 1997 \\
\hline $\begin{array}{l}\text { 龙胆科 } \\
\text { Gentianaceae }\end{array}$ & 龙胆属 Gentiana & $\begin{array}{l}\text { G. arethusae var. delicatula C. } \\
\text { Marquand }\end{array}$ & 云南德钦 Deqin, Yunnan & & 24 & 12 & $2 x$ & 3,800 & PH & $\mathrm{C}$ & 刘建全等, 2002a \\
\hline $\begin{array}{l}\text { 龙胆科 } \\
\text { Gentianaceae }\end{array}$ & 龙胆属 Gentiana & G. aristata Maxim. & 甘肃碌曲 Luqu, Gansu & & 14 & 7 & $2 \mathrm{x}$ & 3,450 & $\mathrm{AH}$ & $\mathrm{C}$ & Küpfer \& Yuan, 1996 \\
\hline $\begin{array}{l}\text { 龙胆科 } \\
\text { Gentianaceae }\end{array}$ & 龙胆属 Gentiana & G. aristata Maxim. & 甘肃玛曲 Maqu, Gansu & & 14 & 7 & $2 \mathrm{x}$ & 3,500 & $\mathrm{AH}$ & C & Yuan \& Küpfer, 1997 \\
\hline $\begin{array}{l}\text { 龙胆科 } \\
\text { Gentianaceae }\end{array}$ & 龙胆属 Gentiana & G. asterocalyx Diels & 云南丽江 Lijiang, Yunnan & & 20 & 10 & $2 \mathrm{x}$ & 2,900 & $\mathrm{AH}$ & C & Küpfer \& Yuan, 1996 \\
\hline $\begin{array}{l}\text { 龙胆科 } \\
\text { Gentianaceae }\end{array}$ & 龙胆属 Gentiana & G. caeruleogrisea T. N. Ho & 青海玛沈 Maqin, Qinghai & & 16 & 8 & $2 x$ & 3,500 & $\mathrm{AH}$ & C & He et al, 2002b \\
\hline $\begin{array}{l}\text { 龙胆科 } \\
\text { Gentianaceae }\end{array}$ & 龙胆属 Gentiana & G. callistantha Diels \& Gilg & 甘肃碌曲 Luqu, Gansu & & 26 & 13 & $2 \mathrm{x}$ & 3,500 & PH & C & Yuan \& Küpfer, 1997 \\
\hline $\begin{array}{l}\text { 龙胆科 } \\
\text { Gentianaceae }\end{array}$ & 龙胆属 Gentiana & G. cephalantha Franchetet. & 云南丽江 Lijiang, Yunnan & & 24 & 12 & $2 x$ & 3,000 & PH & C & 刘建全等, 2002a \\
\hline $\begin{array}{l}\text { 龙胆科 } \\
\text { Gentianaceae }\end{array}$ & 龙胆属 Gentiana & G. chinensis Kusnezow & 四川峨眉山 Emei Mt., Sichuan & & 24 & 12 & $2 \mathrm{x}$ & 3,000 & PH & C & He et al, 2002a \\
\hline
\end{tabular}


王家坚, 彭智邦, 孙航, 聂泽龙, 孟盈. 青藏高原与横断山被子植物区系演化的细胞地理学特征. 生物多样性, 2017, 25 (2): 218-225.

http://www.biodiversity-science.net/CN/10.17520/biods.2016281

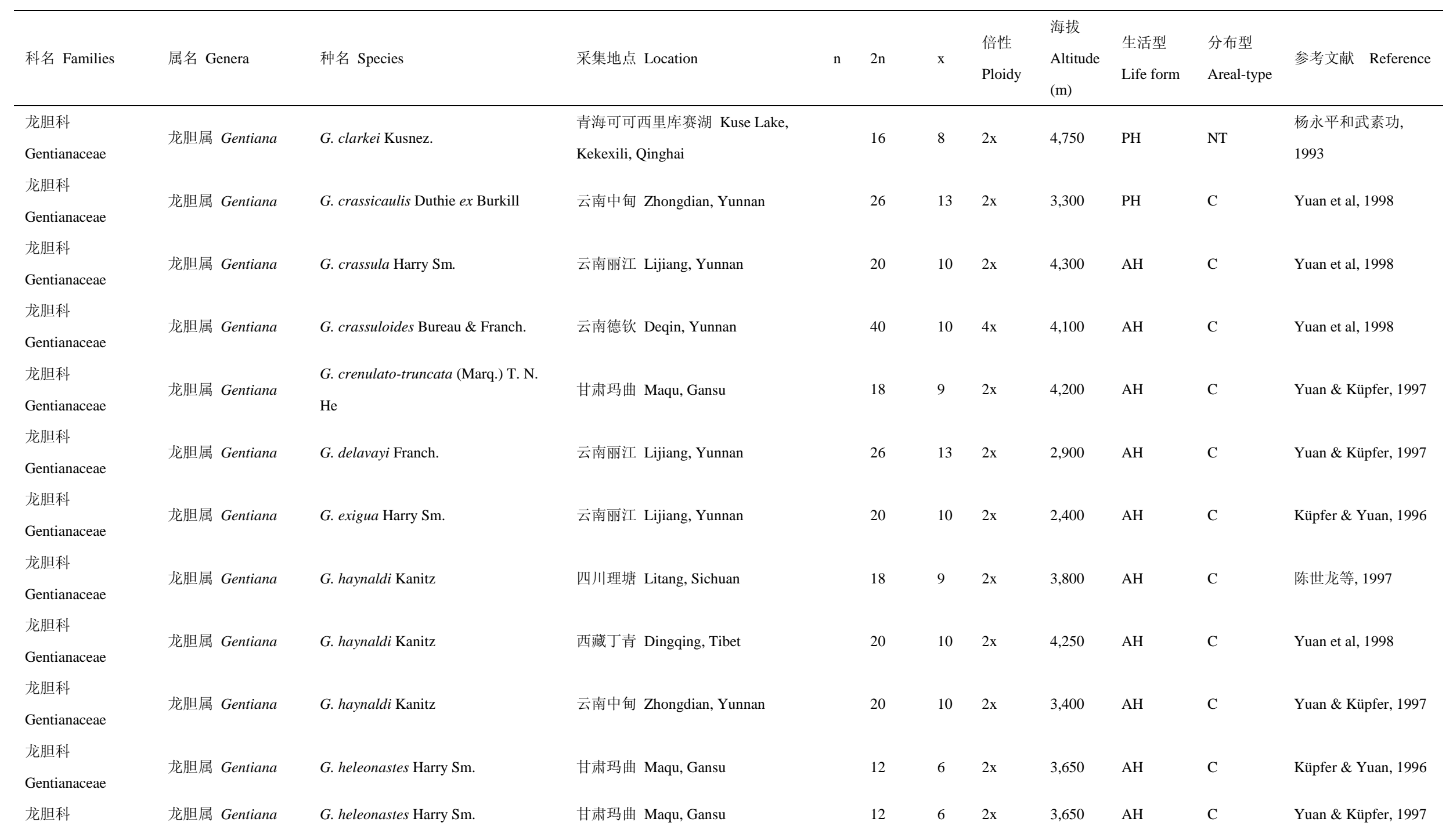


王家坚, 彭智邦, 孙航, 聂泽龙, 孟盈. 青藏高原与横断山被子植物区系演化的细胞地理学特征. 生物多样性, 2017, 25 (2): 218-225.

http://www.biodiversity-science.net/CN/10.17520/biods.2016281

\begin{tabular}{|c|c|c|c|c|c|c|c|c|c|c|c|}
\hline 科名 Families & 属名 Genera & 种名 Species & 采集地点 Location & $\mathrm{n}$ & $2 n$ & $\mathrm{x}$ & $\begin{array}{l}\text { 倍性 } \\
\text { Ploidy }\end{array}$ & $\begin{array}{l}\text { 海拔 } \\
\text { Altitude } \\
\text { (m) }\end{array}$ & $\begin{array}{l}\text { 生活型 } \\
\text { Life form }\end{array}$ & $\begin{array}{l}\text { 分布型 } \\
\text { Areal-type }\end{array}$ & 参考文献 Reference \\
\hline \multicolumn{12}{|l|}{ Gentianaceae } \\
\hline $\begin{array}{l}\text { 龙胆科 } \\
\text { Gentianaceae }\end{array}$ & 龙胆属 Gentiana & G. heleonastes Harry Sm. & 甘肃玛曲 Maqu, Gansu & & 36 & 6 & $6 \mathrm{x}$ & 3,900 & $\mathrm{AH}$ & $\mathrm{C}$ & Yuan et al, 1998 \\
\hline $\begin{array}{l}\text { 龙胆科 } \\
\text { Gentianaceae }\end{array}$ & 龙胆属 Gentiana & G. heterostemon Harry Sm. & 云南大理 Dali, Yunnan & & 20 & 10 & $2 \mathrm{x}$ & 2,100 & $\mathrm{AH}$ & $\mathrm{C}$ & Küpfer \& Yuan, 1996 \\
\hline $\begin{array}{l}\text { 龙胆科 } \\
\text { Gentianaceae }\end{array}$ & 龙胆属 Gentiana & G. hyalina T. N. Ho & 青海玛多 Maduo, Qinghai & & 12 & 6 & $2 \mathrm{x}$ & 4,300 & $\mathrm{AH}$ & C & Yuan \& Küpfer, 1997 \\
\hline $\begin{array}{l}\text { 龙胆科 } \\
\text { Gentianaceae }\end{array}$ & 龙胆属 Gentiana & G. intricata C. Marquand & 云南丽江 Lijiang, Yunnan & & 20 & 10 & $2 \mathrm{x}$ & 3,200 & $\mathrm{AH}$ & C & Küpfer \& Yuan, 1996 \\
\hline $\begin{array}{l}\text { 龙胆科 } \\
\text { Gentianaceae }\end{array}$ & 龙胆属 Gentiana & G. intricata C. Marquand & 云南丽江 Lijiang, Yunnan & & 20 & 10 & $2 \mathrm{x}$ & 2,700 & $\mathrm{AH}$ & $\mathrm{C}$ & Yuan \& Küpfer, 1997 \\
\hline $\begin{array}{l}\text { 龙胆科 } \\
\text { Gentianaceae }\end{array}$ & 龙胆属 Gentiana & G. leucomelaena Maxim. & 四川若尔盖 Ruoergai, Sichuan & & 36 & 9 & $4 \mathrm{x}$ & 4,200 & $\mathrm{AH}$ & $\mathrm{C}$ & Yuan et al, 1998 \\
\hline $\begin{array}{l}\text { 龙胆科 } \\
\text { Gentianaceae }\end{array}$ & 龙胆属 Gentiana & G. Ihassica Burkill & 西藏丁青 Dingqing, Tibet & & 26 & 13 & $2 \mathrm{x}$ & 4,200 & PH & $\mathrm{C}$ & Yuan et al, 1998 \\
\hline $\begin{array}{l}\text { 龙胆科 } \\
\text { Gentianaceae }\end{array}$ & 龙胆属 Gentiana & G. mairei H. Lév. & 云南丽江 Lijiang, Yunnan & & 20 & 10 & $2 \mathrm{x}$ & 3,200 & $\mathrm{AH}$ & C & Yuan et al, 1998 \\
\hline $\begin{array}{l}\text { 龙胆科 } \\
\text { Gentianaceae }\end{array}$ & 龙胆属 Gentiana & G. microdonta Franch. & 云南丽江 Lijiang, Yunnan & & 24 & 12 & $2 \mathrm{x}$ & 3,700 & PH & C & 陈世龙等, 1997 \\
\hline $\begin{array}{l}\text { 龙胆科 } \\
\text { Gentianaceae }\end{array}$ & 龙胆属 Gentiana & G. microdonta Franch. & 云南丽江 Lijiang, Yunnan & & 24 & 12 & $2 \mathrm{x}$ & 2,900 & PH & C & He et al, 2002a \\
\hline $\begin{array}{l}\text { 龙胆科 } \\
\text { Gentianaceae }\end{array}$ & 龙胆属 Gentiana & G. nubigena Edgew. & 青海玛沈 Maqin, Qinghai & & 24 & 12 & $2 \mathrm{x}$ & 4,900 & $\mathrm{PH}$ & C & He et al, 2002b \\
\hline
\end{tabular}


王家坚, 彭智邦, 孙航, 聂泽龙, 孟盈. 青藏高原与横断山被子植物区系演化的细胞地理学特征. 生物多样性, 2017, 25 (2): 218-225.

http://www.biodiversity-science.net/CN/10.17520/biods.2016281

\begin{tabular}{|c|c|c|c|c|c|c|c|c|c|c|c|}
\hline 科名 Families & 属名 Genera & 种名 Species & 采集地点 Location & $\mathrm{n}$ & $2 n$ & $\mathrm{x}$ & $\begin{array}{l}\text { 倍性 } \\
\text { Ploidy }\end{array}$ & $\begin{array}{l}\text { 海拔 } \\
\text { Altitude } \\
\text { (m) }\end{array}$ & $\begin{array}{l}\text { 生活型 } \\
\text { Life form }\end{array}$ & $\begin{array}{l}\text { 分布型 } \\
\text { Areal-type }\end{array}$ & 参考文献 Reference \\
\hline $\begin{array}{l}\text { 龙胆科 } \\
\text { Gentianaceae }\end{array}$ & 龙胆属 Gentiana & G. panthaica Burkill & 云南大理 Dali, Yunnan & & 20 & 10 & $2 \mathrm{x}$ & 3,200 & $\mathrm{AH}$ & C & Yuan \& Küpfer, 1997 \\
\hline $\begin{array}{l}\text { 龙胆科 } \\
\text { Gentianaceae }\end{array}$ & 龙胆属 Gentiana & G. praticola Franch. & 云南大理 Dali, Yunnan & & 20 & 10 & $2 \mathrm{x}$ & 2,200 & PH & C & Küpfer \& Yuan, 1996 \\
\hline $\begin{array}{l}\text { 龙胆科 } \\
\text { Gentianaceae }\end{array}$ & 龙胆属 Gentiana & G. prattii Kusnezow & 甘肃碌曲 Luqu, Gansu & & 18 & 9 & $2 \mathrm{x}$ & 3,500 & $\mathrm{AH}$ & $\mathrm{C}$ & Küpfer \& Yuan, 1996 \\
\hline $\begin{array}{l}\text { 龙胆科 } \\
\text { Gentianaceae }\end{array}$ & 龙胆属 Gentiana & G. prattii Kusnezow & 四川松潘 Songpan, Sichuan & & 20 & 10 & $2 \mathrm{x}$ & 3,700 & $\mathrm{AH}$ & $\mathrm{C}$ & Yuan et al, 1998 \\
\hline $\begin{array}{l}\text { 龙胆科 } \\
\text { Gentianaceae }\end{array}$ & 龙胆属 Gentiana & G. pseudoaquatica Kusnezow & 西藏丁青 Dingqing, Tibet & & 20 & 10 & $2 \mathrm{x}$ & 4,250 & $\mathrm{AH}$ & $\mathrm{C}$ & Yuan et al, 1998 \\
\hline $\begin{array}{l}\text { 龙胆科 } \\
\text { Gentianaceae }\end{array}$ & 龙胆属 Gentiana & G. pseudoaquatica Kusnezow & 甘肃碌曲 Luqu, Gansu & & 20 & 10 & $2 x$ & 3,300 & $\mathrm{AH}$ & C & Küpfer \& Yuan, 1996 \\
\hline $\begin{array}{l}\text { 龙胆科 } \\
\text { Gentianaceae }\end{array}$ & 龙胆属 Gentiana & G. pseudoaquatica Kusnezow & 甘肃玛曲 Maqu, Gansu & & 20 & 10 & $2 \mathrm{x}$ & 3,800 & $\mathrm{AH}$ & $\mathrm{C}$ & Yuan \& Küpfer, 1997 \\
\hline $\begin{array}{l}\text { 龙胆科 } \\
\text { Gentianaceae }\end{array}$ & 龙胆属 Gentiana & G. pseudosquarrosa Harry Sm. & 四川松潘 Songpan, Sichuan & & 20 & 10 & $2 \mathrm{x}$ & 3,400 & $\mathrm{AH}$ & C & Yuan et al, 1998 \\
\hline $\begin{array}{l}\text { 龙胆科 } \\
\text { Gentianaceae }\end{array}$ & 龙胆属 Gentiana & G. pudica Maxim. & 甘肃玛曲 Maqu, Gansu & & 20 & 10 & $2 \mathrm{x}$ & 3,700 & $\mathrm{AH}$ & C & Yuan \& Küpfer, 1997 \\
\hline $\begin{array}{l}\text { 龙胆科 } \\
\text { Gentianaceae }\end{array}$ & 龙胆属 Gentiana & G. serra Franch. & 云南丽江 Lijiang, Yunnan & & 34 & 17 & $2 \mathrm{x}$ & 2,400 & $\mathrm{AH}$ & C & He et al, 2002b \\
\hline $\begin{array}{l}\text { 龙胆科 } \\
\text { Gentianaceae }\end{array}$ & 龙胆属 Gentiana & G. souliei Franch. & 云南丽江 Lijiang, Yunnan & & 46 & 23 & $2 \mathrm{x}$ & 2,400 & $\mathrm{AH}$ & $\mathrm{C}$ & He et al, 2002b \\
\hline 龙胆科 & 龙胆属 Gentiana & G. squarrosa Ledeb. & 甘肃碌曲 Luqu, Gansu & & 38 & 19 & $2 \mathrm{x}$ & 3,700 & $\mathrm{AH}$ & $\mathrm{C}$ & Yuan et al, 1998 \\
\hline
\end{tabular}


王家坚, 彭智邦, 孙航, 聂泽龙, 孟盈. 青藏高原与横断山被子植物区系演化的细胞地理学特征. 生物多样性, 2017, 25 (2): 218-225.

http://www.biodiversity-science.net/CN/10.17520/biods.2016281

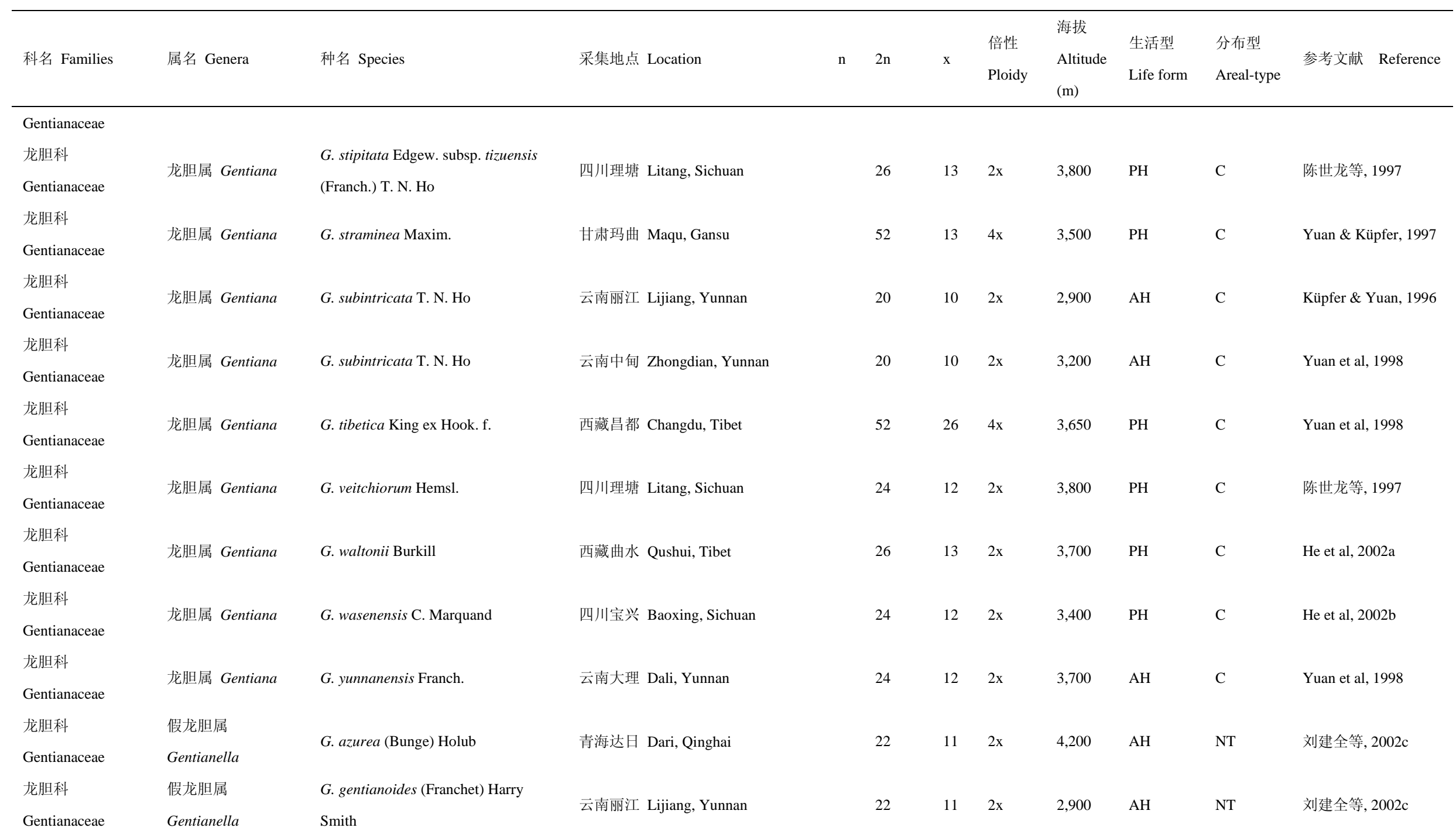


王家坚, 彭智邦, 孙航, 聂泽龙, 孟盈. 青藏高原与横断山被子植物区系演化的细胞地理学特征. 生物多样性, 2017, 25 (2): 218-225.

http://www.biodiversity-science.net/CN/10.17520/biods.2016281

\begin{tabular}{|c|c|c|c|c|c|c|c|c|c|c|c|}
\hline 科名 Families & 属名 Genera & 种名 Species & 采集地点 Location & $\mathrm{n}$ & $2 \mathrm{n}$ & $\mathrm{x}$ & $\begin{array}{l}\text { 倍性 } \\
\text { Ploidy }\end{array}$ & $\begin{array}{l}\text { 海拔 } \\
\text { Altitude } \\
\text { (m) }\end{array}$ & $\begin{array}{l}\text { 生活型 } \\
\text { Life form }\end{array}$ & $\begin{array}{l}\text { 分布型 } \\
\text { Areal-type }\end{array}$ & 参考文献 Reference \\
\hline $\begin{array}{l}\text { 龙胆科 } \\
\text { Gentianaceae }\end{array}$ & $\begin{array}{l}\text { 侯花草属 } \\
\text { Comastoma }\end{array}$ & C. arrectum (Franchet.) Holub & 云南德钦 Deqin, Yunnan & & 18 & 9 & $2 \mathrm{x}$ & 3,900 & AH & NT & $\begin{array}{l}\text { 刘建全和何廷龙, } \\
2002\end{array}$ \\
\hline $\begin{array}{l}\text { 龙胆科 } \\
\text { Gentianaceae }\end{array}$ & $\begin{array}{l}\text { 侯花草属 } \\
\text { Comastoma }\end{array}$ & C. beesianum (W. W. Sm.) Holub & 云南丽江 Lijiang, Yunnan & & 18 & 9 & $2 \mathrm{x}$ & 2,800 & AH & NT & $\begin{array}{l}\text { 刘建全和何廷龙, } \\
2002\end{array}$ \\
\hline $\begin{array}{l}\text { 龙胆科 } \\
\text { Gentianaceae }\end{array}$ & $\begin{array}{l}\text { 侯花草属 } \\
\text { Comastoma }\end{array}$ & C. chiuchiense T. N. Ho \& J. Q. Liu & 青海玛沈 Maqin, Qinghai & & 20 & 10 & $2 \mathrm{x}$ & 4,450 & AH & NT & $\begin{array}{l}\text { 刘建全和何廷龙, } \\
2002\end{array}$ \\
\hline $\begin{array}{l}\text { 龙胆科 } \\
\text { Gentianaceae }\end{array}$ & $\begin{array}{l}\text { 堠花草属 } \\
\text { Comastoma }\end{array}$ & $\begin{array}{l}\text { C. pulmonarium (Turczaninow) } \\
\text { Toyokuni }\end{array}$ & 青海玛沈 Maqin, Qinghai & & 18 & 9 & $2 \mathrm{x}$ & 4,000 & АН & NT & $\begin{array}{l}\text { 刘建全和何廷龙, } \\
2002\end{array}$ \\
\hline $\begin{array}{l}\text { 龙胆科 } \\
\text { Gentianaceae }\end{array}$ & $\begin{array}{l}\text { 堠花草属 } \\
\text { Comastoma }\end{array}$ & C. traillianum (Forrest) Holub & 云南中甸 Zhongdian, Yunnan & & 18 & 9 & $2 \mathrm{x}$ & 3,382 & $\mathrm{AH}$ & NT & $\begin{array}{l}\text { 刘建全和何廷龙, } \\
2002\end{array}$ \\
\hline $\begin{array}{l}\text { 龙胆科 } \\
\text { Gentianaceae }\end{array}$ & $\begin{array}{l}\text { 辐花属 } \\
\text { Lomatogoniopsis }\end{array}$ & L. alpina T. N. Ho \& S. W. Liu & 青海达日 Dari, Qinghai & & 12 & 6 & $2 \mathrm{x}$ & & АН & $\mathrm{EC}$ & 刘建全等, 2002b \\
\hline $\begin{array}{l}\text { 陇牛儿苗科 } \\
\text { Geraniaceae }\end{array}$ & 老鹳草属 Geranium & G. eriostemon Fisch. ex DC. & 四川宝兴 Baoxing, Sichuan & 5 & & 5 & $2 \mathrm{x}$ & 1,800 & PH & C & Hong \& Zhang, 1990 \\
\hline $\begin{array}{l}\text { 陇牛儿苗科 } \\
\text { Geraniaceae }\end{array}$ & 老鸛草属 Geranium & G. platyanthum Duthie & 四川峨眉山 Emei Mt., Sichuan & 9 & & 9 & $2 \mathrm{x}$ & 800 & $\mathrm{PH}$ & NT & Hong \& Zhang, 1990 \\
\hline $\begin{array}{l}\text { 毛莨科 } \\
\text { Ranunculaceae }\end{array}$ & $\begin{array}{l}\text { 罂粟莲花属 } \\
\text { Anemoclema }\end{array}$ & A. glaucifolium (Franch.) W. T. Wang & 云南丽江 Lijiang, Yunnan & & 16 & 8 & $2 \mathrm{x}$ & & $\mathrm{PH}$ & EC & 杨亲二, 2002b \\
\hline 毛莨科 & 罂粟莲花属 & A. glaucifolium (Franch.) W. T. Wang & 云南宁莨 Ninglang, Yunnan & & 16 & 8 & $2 \mathrm{x}$ & & PH & EC & 张国莉和龚洵, 2002 \\
\hline
\end{tabular}


王家坚, 彭智邦, 孙航, 聂泽龙, 孟盈. 青藏高原与横断山被子植物区系演化的细胞地理学特征. 生物多样性, 2017, 25 (2): 218-225.

http://www.biodiversity-science.net/CN/10.17520/biods.2016281

\begin{tabular}{|c|c|c|c|c|c|c|c|c|c|c|c|}
\hline 科名 Families & 属名 Genera & 种名 Species & 采集地点 Location & $\mathrm{n}$ & $2 n$ & $\mathrm{x}$ & $\begin{array}{l}\text { 倍性 } \\
\text { Ploidy }\end{array}$ & $\begin{array}{l}\text { 海拔 } \\
\text { Altitude } \\
\text { (m) }\end{array}$ & $\begin{array}{l}\text { 生活型 } \\
\text { Life form }\end{array}$ & $\begin{array}{l}\text { 分布型 } \\
\text { Areal-type }\end{array}$ & 参考文献 Reference \\
\hline Ranunculaceae & Anemoclema & & & & & & & & & & \\
\hline $\begin{array}{l}\text { 毛莨科 } \\
\text { Ranunculaceae }\end{array}$ & 银莲花属 Anemone & A. begoniifolia H. Lév. \& Vaniot & 四川南川 Nanchuan, Sichuan & & 16 & 8 & $2 \mathrm{x}$ & & $\mathrm{PH}$ & $\mathrm{C}$ & 杨亲二, 2002b \\
\hline $\begin{array}{l}\text { 毛莨科 } \\
\text { Ranunculaceae }\end{array}$ & 银莲花属 Anemone & A. davidi Franch. & 云南维西 Weixi, Yunnan & & 32 & 16 & $4 \mathrm{x}$ & & $\mathrm{PH}$ & $\mathrm{C}$ & 杨亲二, 2002b \\
\hline $\begin{array}{l}\text { 毛莨科 } \\
\text { Ranunculaceae }\end{array}$ & 银莲花属 Anemone & A. demissa Hook. f. \& Thomson & 云南中甸 Zhongdian, Yunnan & & 14 & 7 & $2 \mathrm{x}$ & & $\mathrm{PH}$ & C & 杨亲二, 2002b \\
\hline $\begin{array}{l}\text { 毛莨科 } \\
\text { Ranunculaceae }\end{array}$ & 银莲花属 Anemone & A. flaccida Fr. Schmidt & 云南维西 Weixi, Yunnan & & 14 & 7 & $2 x$ & & PH & $\mathrm{C}$ & 杨亲二, 2002b \\
\hline $\begin{array}{l}\text { 毛莨科 } \\
\text { Ranunculaceae }\end{array}$ & 银莲花属 Anemone & $\begin{array}{l}\text { A. hupehensis Hort. ex Boynton f. alba } \\
\text { W. T. Wang }\end{array}$ & 云南中甸 Zhongdian, Yunnan & & 16 & 8 & $2 \mathrm{x}$ & & $\mathrm{PH}$ & $\mathrm{C}$ & 杨亲二, 2002b \\
\hline $\begin{array}{l}\text { 毛莨科 } \\
\text { Ranunculaceae }\end{array}$ & 银莲花属 Anemone & A. obstusiloba ssp. ovalifolia Brohl & $\begin{array}{l}\text { 青海可可西里乌兰乌拉湖 } \\
\text { Wulanwula Lake, Kekexili, Qinghai }\end{array}$ & & 16 & 8 & $2 x$ & 4,800 & $\mathrm{PH}$ & OWT & $\begin{array}{l}\text { 杨永平和武素功, } \\
1993\end{array}$ \\
\hline $\begin{array}{l}\text { 毛莨科 } \\
\text { Ranunculaceae }\end{array}$ & 银莲花属 Anemone & A. rivularis Wall. & 云南丽江 Lijiang, Yunnan & & 16 & 8 & $2 x$ & & $\mathrm{PH}$ & C & 杨亲二, 2002b \\
\hline $\begin{array}{l}\text { 毛莨科 } \\
\text { Ranunculaceae }\end{array}$ & 银莲花属 Anemone & A. rupestris Wall. & 云南中甸 Zhongdian, Yunnan & & 14 & 7 & $2 \mathrm{x}$ & & $\mathrm{PH}$ & $\mathrm{C}$ & 杨亲二, 2002b \\
\hline $\begin{array}{l}\text { 毛莨科 } \\
\text { Ranunculaceae }\end{array}$ & 银莲花属 Anemone & A. stolonifera Maxim. & 云南中甸 Zhongdian, Yunnan & & 16 & 8 & $2 \mathrm{x}$ & & $\mathrm{PH}$ & $\mathrm{C}$ & 杨亲二, 2002b \\
\hline $\begin{array}{l}\text { 毛莨科 } \\
\text { Ranunculaceae }\end{array}$ & 银莲花属 Anemone & $\begin{array}{l}\text { A. trullifolia var. colestina (Franch.) } \\
\text { Finet \& Gagnep. }\end{array}$ & 云南大理 Dali, Yunnan & & 14 & 7 & $2 \mathrm{x}$ & & $\mathrm{PH}$ & $\mathrm{C}$ & 杨亲二, 2002b \\
\hline $\begin{array}{l}\text { 毛莨科 } \\
\text { Ranunculaceae }\end{array}$ & 银莲花属 Anemone & A. trullifolia var. holophylla Diels & 云南中甸 Zhongdian, Yunnan & & 14 & 7 & $2 x$ & & $\mathrm{PH}$ & C & 杨亲二, 2002b \\
\hline
\end{tabular}


王家坚, 彭智邦, 孙航, 聂泽龙, 孟盈. 青藏高原与横断山被子植物区系演化的细胞地理学特征. 生物多样性, 2017, 25 (2): 218-225.

http://www.biodiversity-science.net/CN/10.17520/biods.2016281

\begin{tabular}{|c|c|c|c|c|c|c|c|c|c|c|c|}
\hline 科名 Families & 属名 Genera & 种名 Species & 采集地点 Location & $\mathrm{n}$ & $2 \mathrm{n}$ & $\mathrm{x}$ & $\begin{array}{l}\text { 倍性 } \\
\text { Ploidy }\end{array}$ & $\begin{array}{l}\text { 海拔 } \\
\text { Altitude } \\
\text { (m) }\end{array}$ & $\begin{array}{l}\text { 生活型 } \\
\text { Life form }\end{array}$ & $\begin{array}{l}\text { 分布型 } \\
\text { Areal-type }\end{array}$ & 参考文献 Reference \\
\hline $\begin{array}{l}\text { 毛莨科 } \\
\text { Ranunculaceae }\end{array}$ & $\begin{array}{l}\text { 鸦踢花属 } \\
\text { Oxygraphis }\end{array}$ & O. delavayi Franch. & 云南维西 Weixi, Yunnan & & 16 & 8 & $2 \mathrm{x}$ & 3,900 & $\mathrm{PH}$ & TA & 杨亲二, 2000a \\
\hline $\begin{array}{l}\text { 毛莨科 } \\
\text { Ranunculaceae }\end{array}$ & $\begin{array}{l}\text { 鸦踢花属 } \\
\text { Oxygraphis }\end{array}$ & O. glacialis (Fish.) Bunge & $\begin{array}{l}\text { 青海可可西里玛章错钦 } \\
\text { Mazhangcuoqin, Kekexili, Qinghai }\end{array}$ & & 16 & 8 & $2 \mathrm{x}$ & 4,900 & $\mathrm{PH}$ & TA & $\begin{array}{l}\text { 杨永平和武素功, } \\
1993\end{array}$ \\
\hline $\begin{array}{l}\text { 毛莨科 } \\
\text { Ranunculaceae }\end{array}$ & $\begin{array}{l}\text { 鸦跖花属 } \\
\text { Oxygraphis }\end{array}$ & O. tenuifolia W. E. Evans & 云南中甸 Zhongdian, Yunnan & & 16 & 8 & $2 \mathrm{x}$ & 4,100 & $\mathrm{PH}$ & TA & 杨亲二, 2000a \\
\hline $\begin{array}{l}\text { 毛莨科 } \\
\text { Ranunculaceae }\end{array}$ & $\begin{array}{l}\text { 星叶草属 } \\
\text { Circaeaster }\end{array}$ & C. agrestis Maxim. & 青海大通 Datong, Qinghai & & 30 & 15 & $2 \mathrm{x}$ & & $\mathrm{PH}$ & $\mathrm{CA}$ & $\begin{array}{l}\text { 孔宏智和杨亲二, } \\
1997\end{array}$ \\
\hline $\begin{array}{l}\text { 毛莨科 } \\
\text { Ranunculaceae }\end{array}$ & $\begin{array}{l}\text { 星果草属 } \\
\text { Asteropyrum }\end{array}$ & $\begin{array}{l}\text { A. peltatum J. R. Drumm. \& } \\
\text { Hutchinson }\end{array}$ & 云南贡山 Gongshan, Yunnan & & 16 & 8 & $2 \mathrm{x}$ & & $\mathrm{PH}$ & EC & 杨亲二等, 1993b \\
\hline $\begin{array}{l}\text { 毛莨科 } \\
\text { Ranunculaceae }\end{array}$ & 乌头属 Aconitum & $\begin{array}{l}\text { A. brachypodium var. Iaxiflorum H. R. } \\
\text { Fletcher \& Lauener }\end{array}$ & 云南中甸 Zhongdian, Yunnan & & 16 & 8 & $2 \mathrm{x}$ & 3,200 & $\mathrm{PH}$ & NT & Yang et al, 1993a \\
\hline $\begin{array}{l}\text { 毛莨科 } \\
\text { Ranunculaceae }\end{array}$ & 乌头属 Aconitum & $\begin{array}{l}\text { A. brevicalcaratum (Finet \& Gagnep.) } \\
\text { Diels }\end{array}$ & 云南丽江 Lijiang, Yunnan & & 32 & 16 & $4 \mathrm{x}$ & & $\mathrm{PH}$ & NT & Yang et al, 1989 \\
\hline $\begin{array}{l}\text { 毛莨科 } \\
\text { Ranunculaceae }\end{array}$ & 乌头属 Aconitum & $\begin{array}{l}\text { A. brevicalcaratum (Finet \& Gagnep.) } \\
\text { Diels }\end{array}$ & 云南鹤庆 Heqing, Yunnan & & 32 & 8 & $4 \mathrm{x}$ & 3,700 & $\mathrm{PH}$ & NT & 杨亲二等, 1994 \\
\hline 毛莨科 & 乌头属 Aconitum & A. brevicalcaratum (Finet \& Gagnep.) & 云南丽江 Lijiang, Yunnan & & 32 & 8 & $4 \mathrm{x}$ & 3,200 & $\mathrm{PH}$ & NT & Yuan \& Yang, 2006b \\
\hline
\end{tabular}


王家坚, 彭智邦, 孙航, 聂泽龙, 孟盈. 青藏高原与横断山被子植物区系演化的细胞地理学特征. 生物多样性, 2017, 25 (2): 218-225.

http://www.biodiversity-science.net/CN/10.17520/biods.2016281

\begin{tabular}{|c|c|c|c|c|c|c|c|c|c|c|c|}
\hline 科名 Families & 属名 Genera & 种名 Species & 采集地点 Location & $\mathrm{n}$ & $2 \mathrm{n}$ & $\mathrm{x}$ & $\begin{array}{l}\text { 倍性 } \\
\text { Ploidy }\end{array}$ & $\begin{array}{l}\text { 海拔 } \\
\text { Altitude } \\
\text { (m) }\end{array}$ & $\begin{array}{l}\text { 生活型 } \\
\text { Life form }\end{array}$ & $\begin{array}{l}\text { 分布型 } \\
\text { Areal-type }\end{array}$ & 参考文献 Reference \\
\hline Ranunculaceae & & Diels & & & & & & & & & \\
\hline $\begin{array}{l}\text { 毛莨科 } \\
\text { Ranunculaceae }\end{array}$ & 乌头属 Aconitum & $\begin{array}{l}\text { A. brevicalcaratum var. parviflorum } \\
\text { Chen \& Liu }\end{array}$ & 云南丽江 Lijiang, Yunnan & & 32 & 8 & $4 \mathrm{x}$ & 4,000 & $\mathrm{PH}$ & NT & 杨亲二等, 1994 \\
\hline $\begin{array}{l}\text { 毛莨科 } \\
\text { Ranunculaceae }\end{array}$ & 乌头属 Aconitum & A. bulleyanum Diels & 云南鹤庆 Heqing, Yunnan & & 16 & 8 & $2 \mathrm{x}$ & & PH & NT & Yang et al, 1989 \\
\hline $\begin{array}{l}\text { 毛莨科 } \\
\text { Ranunculaceae }\end{array}$ & 乌头属 Aconitum & A. carmichaelii Debeaux & 云南大理 Dali, Yunnan & & 64 & 8 & $8 \mathrm{x}$ & & PH & NT & Yang et al, 1989 \\
\hline $\begin{array}{l}\text { 毛莨科 } \\
\text { Ranunculaceae }\end{array}$ & 乌头属 Aconitum & A. contortum Finet \& Gagnep. & 云南云龙 Yunlong, Yunnan & & 16 & 8 & $2 \mathrm{x}$ & 3,400 & PH & NT & Yang et al, 1993a \\
\hline $\begin{array}{l}\text { 毛莨科 } \\
\text { Ranunculaceae }\end{array}$ & 乌头属 Aconitum & A. crassiflorum Hand. -Mazz. & 云南中甸 Zhongdian, Yunnan & & 32 & 8 & $4 \mathrm{x}$ & 3,700 & PH & NT & 杨亲二等, 1994 \\
\hline $\begin{array}{l}\text { 毛莨科 } \\
\text { Ranunculaceae }\end{array}$ & 乌头属 Aconitum & A. crassiflorum Hand. -Mazz. & 云南德钦 Deqin, Yunnan & & 32 & 8 & $4 \mathrm{x}$ & 3,600 & $\mathrm{PH}$ & NT & Yuan \& Yang, 2006b \\
\hline $\begin{array}{l}\text { 毛莨科 } \\
\text { Ranunculaceae }\end{array}$ & 乌头属 Aconitum & A. crassiflorum Hand. -Mazz. & 四川木里 Muli, Sichuan & & 32 & 8 & $4 \mathrm{x}$ & 3,900 & PH & NT & Yuan \& Yang, 2006b \\
\hline
\end{tabular}


王家坚, 彭智邦, 孙航, 聂泽龙, 孟盈. 青藏高原与横断山被子植物区系演化的细胞地理学特征. 生物多样性, 2017, 25 (2): 218-225.

http://www.biodiversity-science.net/CN/10.17520/biods.2016281

\begin{tabular}{|c|c|c|c|c|c|c|c|c|c|c|c|}
\hline 科名 Families & 属名 Genera & 种名 Species & 采集地点 Location & $\mathrm{n}$ & $2 n$ & $\mathrm{x}$ & $\begin{array}{l}\text { 倍性 } \\
\text { Ploidy }\end{array}$ & $\begin{array}{l}\text { 海拔 } \\
\text { Altitude } \\
\text { (m) }\end{array}$ & $\begin{array}{l}\text { 生活型 } \\
\text { Life form }\end{array}$ & $\begin{array}{l}\text { 分布型 } \\
\text { Areal-type }\end{array}$ & 参考文献 Reference \\
\hline $\begin{array}{l}\text { 毛莨科 } \\
\text { Ranunculaceae }\end{array}$ & 乌头属 Aconitum & A. crassiflorum Hand. -Mazz. & 云南中甸 Zhongdian, Yunnan & & 32 & 8 & $4 \mathrm{x}$ & 3,600 & $\mathrm{PH}$ & NT & Yuan \& Yang, 2006b \\
\hline $\begin{array}{l}\text { 毛莨科 } \\
\text { Ranunculaceae }\end{array}$ & 乌头属 Aconitum & A. crassiflorum Hand. -Mazz. & 云南中甸 Zhongdian, Yunnan & & 32 & 8 & $4 \mathrm{x}$ & 3,600 & $\mathrm{PH}$ & NT & Yuan \& Yang, 2006b \\
\hline $\begin{array}{l}\text { 毛莨科 } \\
\text { Ranunculaceae }\end{array}$ & 乌头属 Aconitum & A. crassiflorum Hand. -Mazz. & 四川雅江 Yajiang, Sichuan & & 32 & 8 & $4 \mathrm{x}$ & 3,600 & $\mathrm{PH}$ & NT & Yuan \& Yang, 2006b \\
\hline $\begin{array}{l}\text { 毛莨科 } \\
\text { Ranunculaceae }\end{array}$ & 乌头属 Aconitum & A. crassiflorum Hand. -Mazz. & 四川雅江 Yajiang, Sichuan & & 32 & 16 & $4 \mathrm{x}$ & & $\mathrm{PH}$ & NT & 杨亲二, 2001a \\
\hline $\begin{array}{l}\text { 毛莨科 } \\
\text { Ranunculaceae }\end{array}$ & 乌头属 Aconitum & A. delavayi Franch. & 云南大理 Dali, Yunnan & & 16 & 8 & $2 \mathrm{x}$ & & $\mathrm{PH}$ & NT & 杨亲二, 2001a \\
\hline $\begin{array}{l}\text { 毛莨科 } \\
\text { Ranunculaceae }\end{array}$ & 乌头属 Aconitum & A. delavayi Franch. & 云南丽江 Lijiang, Yunnan & & 16 & 8 & $2 \mathrm{x}$ & 2,900 & $\mathrm{PH}$ & NT & Yang et al, 1993a \\
\hline $\begin{array}{l}\text { 毛茛科 } \\
\text { Ranunculaceae }\end{array}$ & 乌头属 Aconitum & A. episcopale H. Lév. & 云南大理 Dali, Yunnan & & 16 & 8 & $2 \mathrm{x}$ & & $\mathrm{PH}$ & NT & Yang et al, 1989 \\
\hline $\begin{array}{l}\text { 毛莨科 } \\
\text { Ranunculaceae }\end{array}$ & 乌头属 Aconitum & A. fengii W. T. Wang & 云南中甸 Zhongdian, Yunnan & & 16 & 8 & $2 \mathrm{x}$ & 3,970 & $\mathrm{PH}$ & NT & Yang et al, 1993a \\
\hline $\begin{array}{l}\text { 毛莨科 } \\
\text { Ranunculaceae }\end{array}$ & 乌头属 Aconitum & A. fengii W. T. Wang & 云南中甸 Zhongdian, Yunnan & & 32 & 8 & $2 \mathrm{x}$ & 3,700 & $\mathrm{PH}$ & NT & Yang et al, 1993a \\
\hline $\begin{array}{l}\text { 毛莨科 } \\
\text { Ranunculaceae }\end{array}$ & 乌头属 Aconitum & A. fengii W. T. Wang & 云南维西 Weixi, Yunnan & & 16 & 8 & $2 \mathrm{x}$ & & $\mathrm{PH}$ & NT & 杨亲二, 2001a \\
\hline $\begin{array}{l}\text { 毛莨科 } \\
\text { Ranunculaceae }\end{array}$ & 乌头属 Aconitum & A. forrestii Stapf & 云南丽江 Lijiang, Yunnan & & 16 & 8 & $2 \mathrm{x}$ & & $\mathrm{PH}$ & NT & Yang et al, 1989 \\
\hline 毛莨科 & 乌头属 Aconitum & A. georgei Comber & 云南丽江 Lijiang, Yunnan & & 16 & 8 & $2 \mathrm{x}$ & 3,200 & $\mathrm{PH}$ & NT & Yang et al, 1993a \\
\hline
\end{tabular}


王家坚, 彭智邦, 孙航, 聂泽龙, 孟盈. 青藏高原与横断山被子植物区系演化的细胞地理学特征. 生物多样性, 2017, 25 (2): 218-225.

http://www.biodiversity-science.net/CN/10.17520/biods.2016281

\begin{tabular}{|c|c|c|c|c|c|c|c|c|c|c|c|}
\hline 科名 Families & 属名 Genera & 种名 Species & 采集地点 Location & $\mathrm{n}$ & $2 n$ & $\mathrm{x}$ & $\begin{array}{l}\text { 倍性 } \\
\text { Ploidy }\end{array}$ & $\begin{array}{l}\text { 海拔 } \\
\text { Altitude } \\
\text { (m) }\end{array}$ & $\begin{array}{l}\text { 生活型 } \\
\text { Life form }\end{array}$ & $\begin{array}{l}\text { 分布型 } \\
\text { Areal-type }\end{array}$ & 参考文献 Reference \\
\hline \multicolumn{12}{|l|}{ Ranunculaceae } \\
\hline $\begin{array}{l}\text { 毛莨科 } \\
\text { Ranunculaceae }\end{array}$ & 乌头属 Aconitum & A. gymnandrum Maximowicz. & 青海达日 Dari, Qinghai & & 16 & 8 & $2 \mathrm{x}$ & 4,050 & $\mathrm{AH}$ & NT & 刘建全, 2002 \\
\hline $\begin{array}{l}\text { 毛莨科 } \\
\text { Ranunculaceae }\end{array}$ & 乌头属 Aconitum & A. hemsleyanum E. Pritz. ex Diels & 云南德钦 Deqin, Yunnan & & 16 & 8 & $2 \mathrm{x}$ & 3,200 & $\mathrm{PH}$ & NT & Yang et al, 1993a \\
\hline $\begin{array}{l}\text { 毛莨科 } \\
\text { Ranunculaceae }\end{array}$ & 乌头属 Aconitum & A. hemsleyanum E. Pritz. ex Diels & 云南维西 Weixi, Yunnan & & 16 & 8 & $2 \mathrm{x}$ & & $\mathrm{PH}$ & NT & 杨亲二, 2001a \\
\hline $\begin{array}{l}\text { 毛莨科 } \\
\text { Ranunculaceae }\end{array}$ & 乌头属 Aconitum & $\begin{array}{l}\text { A. hemsleyanum var. circinatum W. T. } \\
\text { Wang }\end{array}$ & 四川峨眉山 Emei Mt., Sichuan & & 16 & 8 & $2 \mathrm{x}$ & 2,100 & $\mathrm{PH}$ & NT & $\begin{array}{l}\text { 商效民和李正理, } \\
1984\end{array}$ \\
\hline $\begin{array}{l}\text { 毛莨科 } \\
\text { Ranunculaceae }\end{array}$ & 乌头属 Aconitum & A. legendrei Hand. -Mazz. & 四川石棉 Shimian, Sichuan & & 16 & 8 & $2 \mathrm{x}$ & & $\mathrm{PH}$ & NT & 杨亲二, 2001a \\
\hline $\begin{array}{l}\text { 毛莨科 } \\
\text { Ranunculaceae }\end{array}$ & 乌头属 Aconitum & A. liljestrandii Hand. -Mazz. & 四川雅江 Yajiang, Sichuan & & 16 & 8 & $2 \mathrm{x}$ & & PH & NT & 杨亲二, 2001a \\
\hline $\begin{array}{l}\text { 毛莨科 } \\
\text { Ranunculaceae }\end{array}$ & 乌头属 Aconitum & A. nagarum Stapf & 云南云龙 Yunlong, Yunnan & & 16 & 8 & $2 x$ & & PH & NT & Yang et al, 1993a \\
\hline $\begin{array}{l}\text { 毛莨科 } \\
\text { Ranunculaceae }\end{array}$ & 乌头属 Aconitum & $\begin{array}{l}\text { A. nagarum Stapf var. heterotrichum } \\
\text { H. R. Fletcher \& Lauener }\end{array}$ & 云南维西 Weixi, Yunnan & & 16 & 8 & $2 \mathrm{x}$ & 3,600 & PH & NT & Yang et al, 1993a \\
\hline $\begin{array}{l}\text { 毛莨科 } \\
\text { Ranunculaceae }\end{array}$ & 乌头属 Aconitum & $\begin{array}{l}\text { A. nagarum var. dielsianum (Airy } \\
\text { Shaw) W. T. Wang }\end{array}$ & 云南腾冲 Tengchong, Yunnan & & 16 & 8 & $2 \mathrm{x}$ & & PH & NT & Yang et al, 1989 \\
\hline $\begin{array}{l}\text { 毛莨科 } \\
\text { Ranunculaceae }\end{array}$ & 乌头属 Aconitum & A. naviculare (Brühi) stapf & $\begin{array}{l}\text { 西藏拉萨林周县 Linzhou, Lhasa, } \\
\text { Tibet }\end{array}$ & & 16 & 8 & $2 \mathrm{x}$ & 4,600 & PH & NT & 央金卓嘎等, 2007 \\
\hline $\begin{array}{l}\text { 毛莨科 } \\
\text { Ranunculaceae }\end{array}$ & 乌头属 Aconitum & A. ouvrardianum Hand. -Mazz. & 云南德钦 Deqin, Yunnan & & 16 & 8 & $2 x$ & 3,750 & PH & NT & Yang et al, 1993a \\
\hline
\end{tabular}


王家坚, 彭智邦, 孙航, 聂泽龙, 孟盈. 青藏高原与横断山被子植物区系演化的细胞地理学特征. 生物多样性, 2017, 25 (2): 218-225.

http://www.biodiversity-science.net/CN/10.17520/biods.2016281

\begin{tabular}{|c|c|c|c|c|c|c|c|c|c|c|c|}
\hline 科名 Families & 属名 Genera & 种名 Species & 采集地点 Location & $\mathrm{n}$ & $2 \mathrm{n}$ & $\mathrm{x}$ & $\begin{array}{l}\text { 倍性 } \\
\text { Ploidy }\end{array}$ & $\begin{array}{l}\text { 海拔 } \\
\text { Altitude } \\
\text { (m) }\end{array}$ & $\begin{array}{l}\text { 生活型 } \\
\text { Life form }\end{array}$ & $\begin{array}{l}\text { 分布型 } \\
\text { Areal-type }\end{array}$ & 参考文献 Reference \\
\hline $\begin{array}{l}\text { 毛莨科 } \\
\text { Ranunculaceae }\end{array}$ & 乌头属 Aconitum & A. ouvrardianum Hand. -Mazz. & 云南德钦 Deqin, Yunnan & & 16 & 8 & $2 \mathrm{x}$ & 4,200 & $\mathrm{PH}$ & NT & Yang et al, 1993a \\
\hline $\begin{array}{l}\text { 毛莨科 } \\
\text { Ranunculaceae }\end{array}$ & 乌头属 Aconitum & $\begin{array}{l}\text { A. pendulicarpum Chang ex W. T. } \\
\text { Wang }\end{array}$ & 云南德钦 Deqin, Yunnan & & 16 & 8 & $2 \mathrm{x}$ & & $\mathrm{PH}$ & NT & Yang et al, 1989 \\
\hline $\begin{array}{l}\text { 毛莨科 } \\
\text { Ranunculaceae }\end{array}$ & 乌头属 Aconitum & A. piepunense Hand. -Mazz. & 云南中甸 Zhongdian, Yunnan & & 16 & 8 & $2 \mathrm{x}$ & 3,400 & $\mathrm{PH}$ & NT & Yang et al, 1993a \\
\hline $\begin{array}{l}\text { 毛莨科 } \\
\text { Ranunculaceae }\end{array}$ & 乌头属 Aconitum & A. piepunense Hand. -Mazz. & 云南中甸 Zhongdian, Yunnan & & 32 & 8 & $4 \mathrm{x}$ & 3,200 & $\mathrm{PH}$ & NT & Yang et al, 1993a \\
\hline $\begin{array}{l}\text { 毛莨科 } \\
\text { Ranunculaceae }\end{array}$ & 乌头属 Aconitum & A. piepunense Hand. -Mazz. & 云南中甸 Zhongdian, Yunnan & & 16 & 8 & $2 \mathrm{x}$ & & $\mathrm{PH}$ & NT & 杨亲二, 2001a \\
\hline $\begin{array}{l}\text { 毛莨科 } \\
\text { Ranunculaceae }\end{array}$ & 乌头属 Aconitum & A. rilongense Kadota & $\begin{array}{l}\text { 四川小金夹金山 Jiajin Mt., Xiaojin, } \\
\text { Sichuan }\end{array}$ & & 32 & 8 & $4 \mathrm{x}$ & 3,400 & $\mathrm{PH}$ & NT & Yuan \& Yang, 2006 \\
\hline $\begin{array}{l}\text { 毛莨科 } \\
\text { Ranunculaceae }\end{array}$ & 乌头属 Aconitum & A. rockii Fletcher \& Lauener & 云南中甸 Zhongdian, Yunnan & & 16 & 8 & $2 \mathrm{x}$ & 3,750 & PH & NT & Yang et al, 1993a \\
\hline $\begin{array}{l}\text { 毛莨科 } \\
\text { Ranunculaceae }\end{array}$ & 乌头属 Aconitum & A. rockii Fletcher \& Lauener & 云南中甸 Zhongdian, Yunnan & & 32 & 8 & $4 \mathrm{x}$ & 3,970 & PH & NT & Yang et al, 1993a \\
\hline 毛茛科 & 乌头属 Aconitum & A. scaposum Franch & 四川宝兴 Baoxing, Sichuan & & 16 & 8 & $2 \mathrm{x}$ & & $\mathrm{PH}$ & NT & Yuan \& Yang, 2006 \\
\hline
\end{tabular}


王家坚, 彭智邦, 孙航, 聂泽龙, 孟盈. 青藏高原与横断山被子植物区系演化的细胞地理学特征. 生物多样性, 2017, 25 (2): 218-225.

http://www.biodiversity-science.net/CN/10.17520/biods.2016281

\begin{tabular}{|c|c|c|c|c|c|c|c|c|c|c|c|}
\hline 科名 Families & 属名 Genera & 种名 Species & 采集地点 Location & $\mathrm{n}$ & $2 n$ & $\mathrm{x}$ & $\begin{array}{l}\text { 倍性 } \\
\text { Ploidy }\end{array}$ & $\begin{array}{l}\text { 海拔 } \\
\text { Altitude } \\
\text { (m) }\end{array}$ & $\begin{array}{l}\text { 生活型 } \\
\text { Life form }\end{array}$ & $\begin{array}{l}\text { 分布型 } \\
\text { Areal-type }\end{array}$ & 参考文献 Reference \\
\hline \multicolumn{12}{|l|}{ Ranunculaceae } \\
\hline $\begin{array}{l}\text { 毛莨科 } \\
\text { Ranunculaceae }\end{array}$ & 乌头属 Aconitum & A. scaposum Franch & $\begin{array}{l}\text { 四川天泉二郎山 Erlang Mt., } \\
\text { Tianquan, Sichuan }\end{array}$ & & 16 & 8 & $2 \mathrm{x}$ & & PH & NT & Yuan \& Yang, 2006 \\
\hline $\begin{array}{l}\text { 毛莨科 } \\
\text { Ranunculaceae }\end{array}$ & 乌头属 Aconitum & A. scaposum Franch. & 云南大理 Dali, Yunnan & & 16 & 8 & $2 \mathrm{x}$ & & PH & NT & 杨亲二, 2001a \\
\hline $\begin{array}{l}\text { 毛莨科 } \\
\text { Ranunculaceae }\end{array}$ & 乌头属 Aconitum & A. scaposum Franch. & 云南大理 Dali, Yunnan & & 16 & 8 & $2 \mathrm{x}$ & & PH & NT & Yuan \& Yang, 2006b \\
\hline $\begin{array}{l}\text { 毛莨科 } \\
\text { Ranunculaceae }\end{array}$ & 乌头属 Aconitum & $\begin{array}{l}\text { A. sessiliflorum (Finet \& Gagnep.) } \\
\text { Hand. -Mazz. }\end{array}$ & 四川若尔盖 Ruoergai, Sichuan & & 16 & 8 & $2 \mathrm{x}$ & & PH & NT & 杨亲二, 1996 \\
\hline $\begin{array}{l}\text { 毛莨科 } \\
\text { Ranunculaceae }\end{array}$ & 乌头属 Aconitum & A. sinomontanum Nakai & 四川南坪 Nanping, Sichuan & & 16 & 8 & $2 \mathrm{x}$ & & PH & NT & Yuan \& Yang, 2006 \\
\hline $\begin{array}{l}\text { 毛莨科 } \\
\text { Ranunculaceae }\end{array}$ & 乌头属 Aconitum & A. sinomontanum Nakai & 四川南坪 Nanping, Sichuan & & 16 & 8 & $2 \mathrm{x}$ & & PH & NT & 杨亲二, 1996 \\
\hline $\begin{array}{l}\text { 毛莨科 } \\
\text { Ranunculaceae }\end{array}$ & 乌头属 Aconitum & A. souliei Finet \& Gagnep. & 云南德钦 Deqin, Yunnan & & 16 & 8 & $2 x$ & 4,300 & PH & NT & Yang et al, 1993a \\
\hline $\begin{array}{l}\text { 毛莨科 } \\
\text { Ranunculaceae }\end{array}$ & 乌头属 Aconitum & A. spathulatum W. T. Wang & 云南鹤庆 Heqing, Yunnan & & 16 & 8 & $2 \mathrm{x}$ & & PH & NT & Yang et al, 1989 \\
\hline $\begin{array}{l}\text { 毛莨科 } \\
\text { Ranunculaceae }\end{array}$ & 乌头属 Aconitum & A. stapfianum Hand. -Mazz. & 云南丽江 Lijiang, Yunnan & & 16 & 8 & $2 \mathrm{x}$ & & PH & NT & Yang et al, 1989 \\
\hline $\begin{array}{l}\text { 毛莨科 } \\
\text { Ranunculaceae }\end{array}$ & 乌头属 Aconitum & $\begin{array}{l}\text { A. stramineiflorum Chang ex W. T. } \\
\text { Wang }\end{array}$ & 云南维西 Weixi, Yunnan & & 16 & 8 & $2 \mathrm{x}$ & & PH & NT & Yang et al, 1993a \\
\hline $\begin{array}{l}\text { 毛莨科 } \\
\text { Ranunculaceae }\end{array}$ & 乌头属 Aconitum & A. tanguticum (Maxim.) Stapf & $\begin{array}{l}\text { 青海祁连县冰沟大坂 Binggou, } \\
\text { Qilian, Qinghai }\end{array}$ & & 16 & 8 & $2 \mathrm{x}$ & 4,200 & PH & NT & $\begin{array}{l}\text { 黄荣福和沈颂东, } \\
1999\end{array}$ \\
\hline
\end{tabular}


王家坚, 彭智邦, 孙航, 聂泽龙, 孟盈. 青藏高原与横断山被子植物区系演化的细胞地理学特征. 生物多样性, 2017, 25 (2): 218-225.

http://www.biodiversity-science.net/CN/10.17520/biods.2016281

\begin{tabular}{|c|c|c|c|c|c|c|c|c|c|c|c|}
\hline 科名 Families & 属名 Genera & 种名 Species & 采集地点 Location & $\mathrm{n}$ & $2 n$ & $\mathrm{x}$ & $\begin{array}{l}\text { 倍性 } \\
\text { Ploidy }\end{array}$ & $\begin{array}{l}\text { 海拔 } \\
\text { Altitude } \\
\text { (m) }\end{array}$ & $\begin{array}{l}\text { 生活型 } \\
\text { Life form }\end{array}$ & $\begin{array}{l}\text { 分布型 } \\
\text { Areal-type }\end{array}$ & 参考文献 Reference \\
\hline $\begin{array}{l}\text { 毛莨科 } \\
\text { Ranunculaceae }\end{array}$ & 乌头属 Aconitum & A. tanguticum (Maximowicz.) Stapf & 青海玉树 Yushu, Qinghai & & 16 & 8 & $2 \mathrm{x}$ & 3,500 & $\mathrm{PH}$ & NT & 刘建全, 2002 \\
\hline $\begin{array}{l}\text { 毛莨科 } \\
\text { Ranunculaceae }\end{array}$ & 乌头属 Aconitum & A. tongolense Ulbr. & 四川理县 Lixian County, Sichuan & & 16 & 8 & $2 \mathrm{x}$ & & $\mathrm{PH}$ & NT & 杨亲二, 2001a \\
\hline $\begin{array}{l}\text { 毛莨科 } \\
\text { Ranunculaceae }\end{array}$ & 乌头属 Aconitum & A. transsectum Diels & 云南丽江 Lijiang, Yunnan & & 16 & 8 & $2 \mathrm{x}$ & & $\mathrm{PH}$ & NT & Yang et al, 1989 \\
\hline $\begin{array}{l}\text { 毛莨科 } \\
\text { Ranunculaceae }\end{array}$ & 乌头属 Aconitum & A. transsectum Diels & 云南丽江 Lijiang, Yunnan & & 16 & 8 & $2 \mathrm{x}$ & 3,600 & $\mathrm{PH}$ & NT & Yang et al, 1993a \\
\hline $\begin{array}{l}\text { 毛莨科 } \\
\text { Ranunculaceae }\end{array}$ & 乌头属 Aconitum & A. tsaii W. T. Wang & 云南沪水 Lushui, Yunnan & & 16 & 8 & $2 \mathrm{x}$ & 3,400 & PH & NT & Yang et al, 1993a \\
\hline $\begin{array}{l}\text { 毛莨科 } \\
\text { Ranunculaceae }\end{array}$ & 乌头属 Aconitum & A. tuguancunense Q. E. Yang & 云南中甸 Zhongdian, Yunnan & & 16 & 8 & $2 \mathrm{x}$ & & $\mathrm{PH}$ & NT & 杨亲二和龚洵, 1995 \\
\hline $\begin{array}{l}\text { 毛莨科 } \\
\text { Ranunculaceae }\end{array}$ & 乌头属 Aconitum & A. tuguancunense Q. E. Yang & 云南中甸 Zhongdian, Yunnan & & 16 & 8 & $2 \mathrm{x}$ & 2,800 & $\mathrm{PH}$ & NT & Yang et al, 1993a \\
\hline $\begin{array}{l}\text { 毛莨科 } \\
\text { Ranunculaceae }\end{array}$ & 乌头属 Aconitum & A. wangii Q. E. Yang & 云南丽江 Lijiang, Yunnan & & 16 & 8 & $2 \mathrm{x}$ & 3,200 & $\mathrm{PH}$ & NT & Yang et al, 1993a \\
\hline $\begin{array}{l}\text { 毛莨科 } \\
\text { Ranunculaceae }\end{array}$ & 乌头属 Aconitum & A. wardii Fletcher \& Lauener & 云南德钦 Deqin, Yunnan & & 32 & 16 & $4 \mathrm{x}$ & & PH & NT & 杨亲二等, 1994 \\
\hline $\begin{array}{l}\text { 毛莨科 } \\
\text { Ranunculaceae }\end{array}$ & 铁线莲属 Clematis & C. brevicaudata DC. & 云南德钦 Deqin, Yunnan & & 16 & 8 & $2 \mathrm{x}$ & & $\mathrm{PH}$ & C & 杨亲二, 2002b \\
\hline $\begin{array}{l}\text { 毛莨科 } \\
\text { Ranunculaceae }\end{array}$ & 铁线莲属 Clematis & C. chrysocoma Franch. & 云南丽江 Lijiang, Yunnan & & 16 & 8 & $2 \mathrm{x}$ & & PH & $\mathrm{C}$ & 杨亲二, 2002b \\
\hline 毛莨科 & 铁线莲属 Clematis & C. kockiana C. K. Schneid. & 云南云龙 Yunlong, Yunnan & & 16 & 8 & $2 \mathrm{x}$ & & PH & $\mathrm{C}$ & 杨亲二, 2002b \\
\hline
\end{tabular}


王家坚, 彭智邦, 孙航, 聂泽龙, 孟盈. 青藏高原与横断山被子植物区系演化的细胞地理学特征. 生物多样性, 2017, 25 (2): 218-225.

http://www.biodiversity-science.net/CN/10.17520/biods.2016281

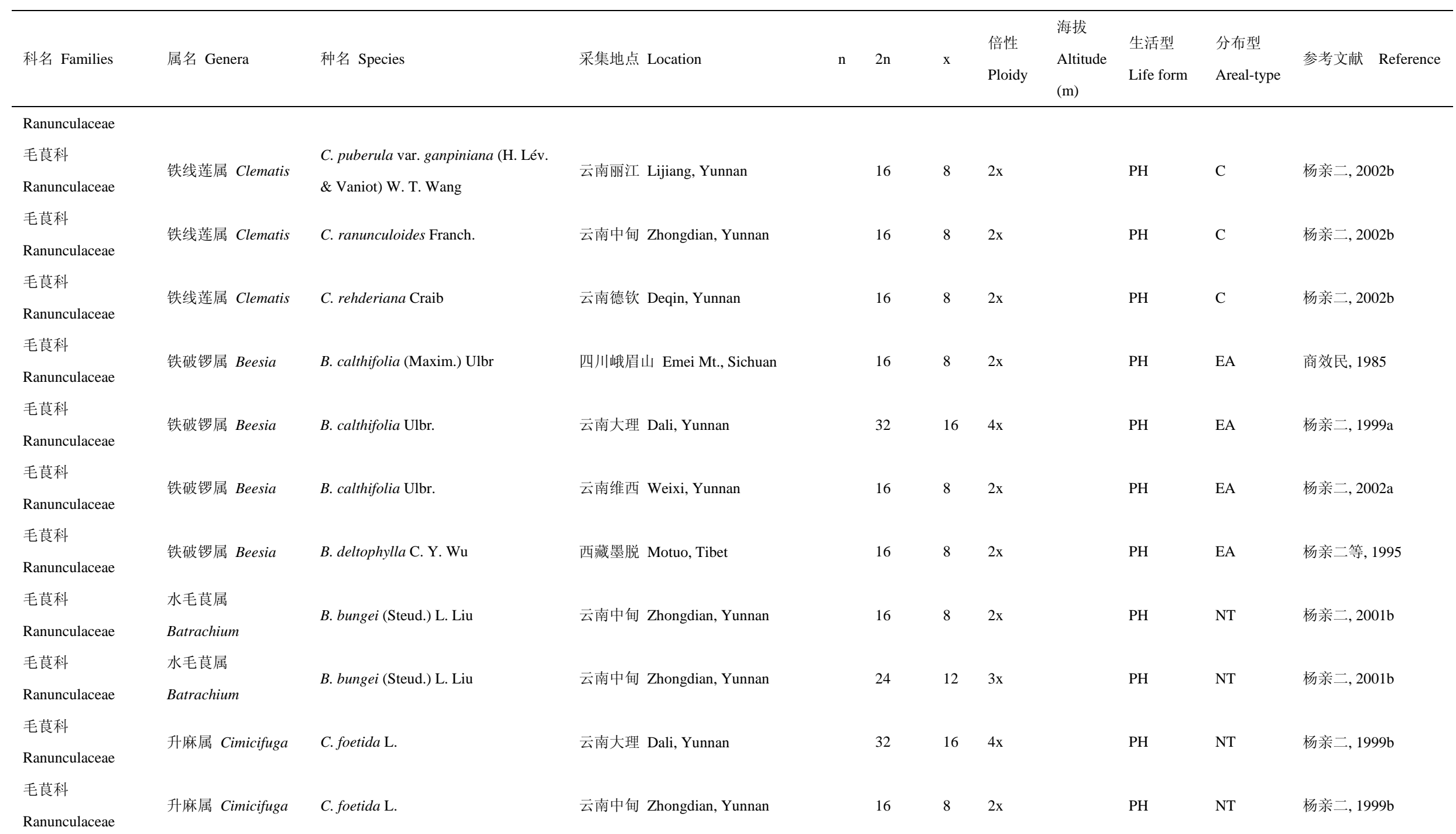


王家坚, 彭智邦, 孙航, 聂泽龙, 孟盈. 青藏高原与横断山被子植物区系演化的细胞地理学特征. 生物多样性, 2017, 25 (2): 218-225.

http://www.biodiversity-science.net/CN/10.17520/biods.2016281

\begin{tabular}{|c|c|c|c|c|c|c|c|c|c|c|c|}
\hline 科名 Families & 属名 Genera & 种名 Species & 采集地点 Location & $\mathrm{n}$ & $2 n$ & $\mathrm{x}$ & $\begin{array}{l}\text { 倍性 } \\
\text { Ploidy }\end{array}$ & $\begin{array}{l}\text { 海拔 } \\
\text { Altitude } \\
\text { (m) }\end{array}$ & $\begin{array}{l}\text { 生活型 } \\
\text { Life form }\end{array}$ & $\begin{array}{l}\text { 分布型 } \\
\text { Areal-type }\end{array}$ & 参考文献 Reference \\
\hline $\begin{array}{l}\text { 毛茛科 } \\
\text { Ranunculaceae }\end{array}$ & 升麻属 Cimicifuga & C. foetida $\mathrm{L}$. & 云南中甸 Zhongdian, Yunnan & & 16 & 8 & $2 \mathrm{x}$ & & PH & NT & 杨亲二等, 1993b \\
\hline $\begin{array}{l}\text { 毛莨科 } \\
\text { Ranunculaceae }\end{array}$ & 升麻属 Cimicifuga & $\begin{array}{l}\text { C. foetida L. var. velutina Franch. ex } \\
\text { Finet \& Gagnep. }\end{array}$ & 云南丽江 Lijiang, Yunnan & & 16 & 8 & $2 \mathrm{x}$ & & PH & NT & 杨亲二, 1999b \\
\hline $\begin{array}{l}\text { 毛莨科 } \\
\text { Ranunculaceae }\end{array}$ & 升麻属 Cimicifuga & C. simplex Wormsk. ex DC. & 四川木里 Muli, Sichuan & & 16 & 8 & $2 \mathrm{x}$ & & PH & NT & 杨亲二, 1999b \\
\hline $\begin{array}{l}\text { 毛莨科 } \\
\text { Ranunculaceae }\end{array}$ & 升麻属 Cimicifuga & C. yunnanensis Hsiao & 云南德钦 Deqin, Yunnan & & 16 & 8 & $2 \mathrm{x}$ & & PH & NT & 杨亲二, 2002a \\
\hline $\begin{array}{l}\text { 毛莨科 } \\
\text { Ranunculaceae }\end{array}$ & 升麻属 Cimicifuga & C. yunnanensis Hsiao. & 云南丽江 Lijiang, Yunnan & & 16 & 8 & $2 \mathrm{x}$ & & PH & NT & 杨亲二, 1999b \\
\hline $\begin{array}{l}\text { 毛莨科 } \\
\text { Ranunculaceae }\end{array}$ & 毛茛属 Ranunculus & R. cantoniensis DC. & 云南中甸 Zhongdian, Yunnan & & 32 & 16 & $4 \mathrm{x}$ & & PH & C & 邓院芳等, 2013 \\
\hline $\begin{array}{l}\text { 毛莨科 } \\
\text { Ranunculaceae }\end{array}$ & 毛茛属 Ranunculus & R. felixii H. Lév. & 云南丽江 Lijiang, Yunnan & & 32 & 8 & $4 \mathrm{x}$ & 3,600 & $\mathrm{PH}$ & $\mathrm{C}$ & 杨亲二, 2000b \\
\hline $\begin{array}{l}\text { 毛莨科 } \\
\text { Ranunculaceae }\end{array}$ & 毛茛属 Ranunculus & R. ficariifolia H. Lév. \& Vaniot & 云南维西 Weixi, Yunnan & & 32 & 16 & $4 \mathrm{x}$ & & PH & C & 杨亲二, 2001b \\
\hline $\begin{array}{l}\text { 毛莨科 } \\
\text { Ranunculaceae }\end{array}$ & 毛莨属 Ranunculus & R. involucratus Maxim. & 青海玛多 Maduo, Qinghai & & 16 & 8 & $2 \mathrm{x}$ & 4,450 & PH & NT & Huang et al, 1996a \\
\hline $\begin{array}{l}\text { 毛莨科 } \\
\text { Ranunculaceae }\end{array}$ & 毛莨属 Ranunculus & R. japonicus Thunb. & 四川雅安 Ya’an, Sichuan & & 14 & 7 & $2 \mathrm{x}$ & & PH & C & 杨亲二, 2001b \\
\hline $\begin{array}{l}\text { 毛莨科 } \\
\text { Ranunculaceae }\end{array}$ & 毛茛属 Ranunculus & R. laetus Wall. & 云南大理 Dali, Yunnan & & 14 & 7 & $2 \mathrm{x}$ & & PH & $\mathrm{C}$ & 杨亲二, 2001b \\
\hline 毛莨科 & 毛莨属 Ranunculus & R. nematolobus Hand. -Mazz. & 云南大理 Dali, Yunnan & & 16 & 8 & $2 \mathrm{x}$ & & PH & $\mathrm{C}$ & 杨亲二, 2001b \\
\hline
\end{tabular}


王家坚, 彭智邦, 孙航, 聂泽龙, 孟盈. 青藏高原与横断山被子植物区系演化的细胞地理学特征. 生物多样性, 2017, 25 (2): 218-225.

http://www.biodiversity-science.net/CN/10.17520/biods.2016281

\begin{tabular}{|c|c|c|c|c|c|c|c|c|c|c|c|}
\hline 科名 Families & 属名 Genera & 种名 Species & 采集地点 Location & $\mathrm{n}$ & $2 n$ & $\mathrm{x}$ & $\begin{array}{l}\text { 倍性 } \\
\text { Ploidy }\end{array}$ & $\begin{array}{l}\text { 海拔 } \\
\text { Altitude } \\
(\mathrm{m})\end{array}$ & $\begin{array}{l}\text { 生活型 } \\
\text { Life form }\end{array}$ & $\begin{array}{l}\text { 分布型 } \\
\text { Areal-type }\end{array}$ & 参考文献 Reference \\
\hline \multicolumn{12}{|l|}{ Ranunculaceae } \\
\hline $\begin{array}{l}\text { 毛莨科 } \\
\text { Ranunculaceae }\end{array}$ & 毛莨属 Ranunculus & R. potanini Komarov & 云南中甸 Zhongdian, Yunnan & & 32 & 16 & $4 \mathrm{x}$ & & $\mathrm{PH}$ & $\mathrm{C}$ & 杨亲二, 2001b \\
\hline $\begin{array}{l}\text { 毛莨科 } \\
\text { Ranunculaceae }\end{array}$ & 毛茛属 Ranunculus & $\begin{array}{l}\text { R. pulchellus var. stracheyanus } \\
\text { (Maxim.) Hand. -Mazz. }\end{array}$ & 云南中甸 Zhongdian, Yunnan & & 32 & 16 & $4 \mathrm{x}$ & & $\mathrm{PH}$ & $\mathrm{C}$ & 邓院芳等, 2013 \\
\hline $\begin{array}{l}\text { 毛莨科 } \\
\text { Ranunculaceae }\end{array}$ & 毛茛属 Ranunculus & R. repens L. & 云南德钦 Deqin, Yunnan & & 32 & 16 & $4 \mathrm{x}$ & & PH & $\mathrm{C}$ & 邓院芳等, 2013 \\
\hline $\begin{array}{l}\text { 毛莨科 } \\
\text { Ranunculaceae }\end{array}$ & 毛茛属 Ranunculus & R. repens L. & 云南丽江 Lijiang, Yunnan & & 32 & 16 & $4 \mathrm{x}$ & & PH & $\mathrm{C}$ & 邓院芳等, 2013 \\
\hline $\begin{array}{l}\text { 毛莨科 } \\
\text { Ranunculaceae }\end{array}$ & 毛茛属 Ranunculus & R. repens L. & 云南香格里拉 Shangri-la, Yunnan & & 32 & 16 & $4 \mathrm{x}$ & & $\mathrm{PH}$ & $\mathrm{C}$ & 邓院芳等, 2013 \\
\hline $\begin{array}{l}\text { 毛莨科 } \\
\text { Ranunculaceae }\end{array}$ & 毛莨属 Ranunculus & R. sinovaginatus W. T. Wang & 云南德钦 Deqin, Yunnan & & 32 & 16 & $4 \mathrm{x}$ & & $\mathrm{PH}$ & $\mathrm{C}$ & 杨亲二, 2001b \\
\hline $\begin{array}{l}\text { 毛莨科 } \\
\text { Ranunculaceae }\end{array}$ & 毛莨属 Ranunculus & R. tanguticus (Finet \& Gagnep.) Hao & 四川理县 Lixian County, Sichuan & & 32 & 16 & $4 \mathrm{x}$ & & PH & $\mathrm{C}$ & 杨亲二, 2001b \\
\hline $\begin{array}{l}\text { 毛莨科 } \\
\text { Ranunculaceae }\end{array}$ & 毛茛属 Ranunculus & R. trigonus Hand. -Mazz. & 云南丽江 Lijiang, Yunnan & & 16 & 8 & $2 \mathrm{x}$ & & PH & C & 杨亲二, 2001b \\
\hline $\begin{array}{l}\text { 毛莨科 } \\
\text { Ranunculaceae }\end{array}$ & 毛茛属 Ranunculus & R. wangianus Q. E. Yang & $\begin{array}{l}\text { 云南维西塔城科那 Weixitacheng, } \\
\text { Yunnan }\end{array}$ & & 48 & 8 & $6 \mathrm{x}$ & 3,300 & $\mathrm{PH}$ & $\mathrm{C}$ & 杨亲二, 2000 \\
\hline $\begin{array}{l}\text { 毛莨科 } \\
\text { Ranunculaceae }\end{array}$ & 毛茛属 Ranunculus & R. yunnanensis Franch. & 云南大理 Dali, Yunnan & & 16 & 8 & $2 \mathrm{x}$ & 3,400 & PH & $\mathrm{C}$ & 杨亲二, 2000b \\
\hline $\begin{array}{l}\text { 毛莨科 } \\
\text { Ranunculaceae }\end{array}$ & 驴蹄草属 Caltha & C. palustris $\mathrm{L}$. & 云南大理 Dali, Yunnan & & 32 & 16 & $4 \mathrm{x}$ & & PH & NT & 杨亲二, 2002a \\
\hline
\end{tabular}


王家坚, 彭智邦, 孙航, 聂泽龙, 孟盈. 青藏高原与横断山被子植物区系演化的细胞地理学特征. 生物多样性, 2017, 25 (2): 218-225.

http://www.biodiversity-science.net/CN/10.17520/biods.2016281

\begin{tabular}{|c|c|c|c|c|c|c|c|c|c|c|c|}
\hline 科名 Families & 属名 Genera & 种名 Species & 采集地点 Location & $\mathrm{n}$ & $2 n$ & $\mathrm{x}$ & $\begin{array}{l}\text { 倍性 } \\
\text { Ploidy }\end{array}$ & $\begin{array}{l}\text { 海拔 } \\
\text { Altitude } \\
\text { (m) }\end{array}$ & $\begin{array}{l}\text { 生活型 } \\
\text { Life form }\end{array}$ & $\begin{array}{l}\text { 分布型 } \\
\text { Areal-type }\end{array}$ & 参考文献 Reference \\
\hline $\begin{array}{l}\text { 毛莨科 } \\
\text { Ranunculaceae }\end{array}$ & 驴蹄草属 Caltha & C. palustris $\mathrm{L}$. & 云南德钦 Deqin, Yunnan & & 64 & 8 & $8 \mathrm{x}$ & & $\mathrm{PH}$ & NT & 杨亲二, 2002a \\
\hline $\begin{array}{l}\text { 毛莨科 } \\
\text { Ranunculaceae }\end{array}$ & 驴蹄草属 Caltha & C. palustris $\mathrm{L}$. & 云南中甸 Zhongdian, Yunnan & & 48 & 8 & $6 \mathrm{x}$ & & $\mathrm{PH}$ & NT & 杨亲二, 2002a \\
\hline $\begin{array}{l}\text { 毛莨科 } \\
\text { Ranunculaceae }\end{array}$ & 类叶升麻属 Actaea & A. asiatica Hara & 云南大理 Dali, Yunnan & & 16 & 8 & $2 \mathrm{x}$ & & $\mathrm{PH}$ & NT & 杨亲二, 1998 \\
\hline $\begin{array}{l}\text { 毛莨科 } \\
\text { Ranunculaceae }\end{array}$ & 类叶升麻属 Actaea & A. asiatica Hara & 云南中甸 Zhongdian, Yunnan & & 16 & 8 & $2 \mathrm{x}$ & & $\mathrm{PH}$ & NT & 杨亲二, 2002a \\
\hline $\begin{array}{l}\text { 毛莨科 } \\
\text { Ranunculaceae }\end{array}$ & 金莲花属 Trollius & T. pumilus var. tanguticus Brhl & $\begin{array}{l}\text { 青海门源县冷龙岭 Lenglong Mt., } \\
\text { Menyuan, Qinghai }\end{array}$ & & 16 & 8 & $2 \mathrm{x}$ & 4,200 & $\mathrm{PH}$ & NT & $\begin{array}{l}\text { 黄荣福和沈颂东, } \\
1999\end{array}$ \\
\hline $\begin{array}{l}\text { 毛莨科 } \\
\text { Ranunculaceae }\end{array}$ & 金莲花属 Trollius & T. yunnanensis Ulbr. & 云南丽江 Lijiang, Yunnan & & 16 & 8 & $2 \mathrm{x}$ & & $\mathrm{PH}$ & NT & 杨亲二, 2002a \\
\hline $\begin{array}{l}\text { 毛莨科 } \\
\text { Ranunculaceae }\end{array}$ & $\begin{array}{l}\text { 碱毛莨属 } \\
\text { Halerpestes }\end{array}$ & H. sarmentosa (Adams) Komarov & 云南中甸 Zhongdian, Yunnan & & 32 & 16 & $4 \mathrm{x}$ & & $\mathrm{PH}$ & NT & 杨亲二, 2001b \\
\hline $\begin{array}{l}\text { 毛莨科 } \\
\text { Ranunculaceae }\end{array}$ & $\begin{array}{l}\text { 鸡爪草属 } \\
\text { Calathodes }\end{array}$ & C. oxycarpa Sprague & 云南大理 Dali, Yunnan & & 16 & 8 & $2 \mathrm{x}$ & 2,800 & $\mathrm{PH}$ & EA & 杨亲二, 1995 \\
\hline $\begin{array}{l}\text { 毛莨科 } \\
\text { Ranunculaceae }\end{array}$ & $\begin{array}{l}\text { 鸡爪草属 } \\
\text { Calathodes }\end{array}$ & C. oxycarpa Sprague & 云南大理 Dali, Yunnan & & 16 & 8 & $2 \mathrm{x}$ & & $\mathrm{PH}$ & EA & 杨亲二, 2002a \\
\hline $\begin{array}{l}\text { 毛莨科 } \\
\text { Ranunculaceae }\end{array}$ & $\begin{array}{l}\text { 鸡爪草属 } \\
\text { Calathodes }\end{array}$ & C. oxycarpa Sprague & 四川峨眉山 Emei Mt., Sichuan & & 16 & 8 & $2 \mathrm{x}$ & 2,400 & $\mathrm{PH}$ & EA & 张芝玉, 1982 \\
\hline $\begin{array}{l}\text { 毛莨科 } \\
\text { Ranunculaceae }\end{array}$ & 黄三七属 Souliea & S. vaginata Franch. & 云南中甸 Zhongdian, Yunnan & & 16 & 8 & $2 \mathrm{x}$ & & $\mathrm{PH}$ & EA & 杨亲二, 2002a \\
\hline 毛莨科 & 黄连属 Coptis & C. deltoidea C. Y. Cheng \& P. G. & 四川峨眉山双水井 Shuangshuijing, & & 27 & 9 & $3 \mathrm{x}$ & 2,300 & $\mathrm{AH}$ & NT & 黄䩀等, 2013 \\
\hline
\end{tabular}


王家坚, 彭智邦, 孙航, 聂泽龙, 孟盈. 青藏高原与横断山被子植物区系演化的细胞地理学特征. 生物多样性, 2017, 25 (2): 218-225.

http://www.biodiversity-science.net/CN/10.17520/biods.2016281

\begin{tabular}{|c|c|c|c|c|c|c|c|c|c|c|c|}
\hline 科名 Families & 属名 Genera & 种名 Species & 采集地点 Location & $\mathrm{n}$ & $2 \mathrm{n}$ & $\mathrm{x}$ & $\begin{array}{l}\text { 倍性 } \\
\text { Ploidy }\end{array}$ & $\begin{array}{l}\text { 海拔 } \\
\text { Altitude } \\
\text { (m) }\end{array}$ & $\begin{array}{l}\text { 生活型 } \\
\text { Life form }\end{array}$ & $\begin{array}{l}\text { 分布型 } \\
\text { Areal-type }\end{array}$ & 参考文献 Reference \\
\hline Ranunculaceae & & Xiao & Emei Mt., Sichuan & & & & & & & & \\
\hline $\begin{array}{l}\text { 毛茛科 } \\
\text { Ranunculaceae }\end{array}$ & 黄连属 Coptis & C. teeta Wall. & 云南贡山 Gongshan, Yunnan & & 18 & 9 & $2 \mathrm{x}$ & & АН & NT & 杨亲二等, 1993b \\
\hline $\begin{array}{l}\text { 毛莨科 } \\
\text { Ranunculaceae }\end{array}$ & 翠雀属 Delphinium & D. albocoeruleum Maxim. & 青海甘德 Gande, Qinghai & & 16 & 8 & $2 \mathrm{x}$ & 4,150 & $\mathrm{PH}$ & NT & $\begin{array}{l}\text { 刘建全和何延农, } \\
1999\end{array}$ \\
\hline $\begin{array}{l}\text { 毛莨科 } \\
\text { Ranunculaceae }\end{array}$ & 翠雀属 Delphinium & D. albocoeruleum Maxim. & 青海德令哈 Delingha, Qinghai & & 16 & 8 & $2 \mathrm{x}$ & & $\mathrm{PH}$ & NT & Yuan \& Yang, 2008 \\
\hline $\begin{array}{l}\text { 毛莨科 } \\
\text { Ranunculaceae }\end{array}$ & 翠雀属 Delphinium & D. batangense Finet \& Gagnep. & 云南德钦 Deqin, Yunnan & & 16 & 8 & $2 \mathrm{x}$ & & PH & NT & Yuan \& Yang, 2008 \\
\hline $\begin{array}{l}\text { 毛莨科 } \\
\text { Ranunculaceae }\end{array}$ & 翠雀属 Delphinium & D. batangense Finet \& Gagnep. & 云南中甸 Zhongdian, Yunnan & & 16 & 8 & $2 \mathrm{x}$ & & PH & NT & Yuan \& Yang, 2008 \\
\hline $\begin{array}{l}\text { 毛莨科 } \\
\text { Ranunculaceae }\end{array}$ & 翠雀属 Delphinium & D. beesianum W. W. Sm. & 云南德钦 Deqin, Yunnan & & 16 & 8 & $2 \mathrm{x}$ & & PH & NT & Yuan \& Yang, 2008 \\
\hline $\begin{array}{l}\text { 毛莨科 } \\
\text { Ranunculaceae }\end{array}$ & 璻雀属 Delphinium & D. beesianum $\mathrm{W}$. W. Sm. & 云南丽江 Lijiang, Yunnan & & 16 & 8 & $2 \mathrm{x}$ & & PH & NT & Yuan \& Yang, 2008 \\
\hline
\end{tabular}


王家坚, 彭智邦, 孙航, 聂泽龙, 孟盈. 青藏高原与横断山被子植物区系演化的细胞地理学特征. 生物多样性, 2017, 25 (2): 218-225.

http://www.biodiversity-science.net/CN/10.17520/biods.2016281

\begin{tabular}{|c|c|c|c|c|c|c|c|c|c|c|c|}
\hline 科名 Families & 属名 Genera & 种名 Species & 采集地点 Location & $\mathrm{n}$ & $2 n$ & $\mathrm{x}$ & $\begin{array}{l}\text { 倍性 } \\
\text { Ploidy }\end{array}$ & $\begin{array}{l}\text { 海拔 } \\
\text { Altitude } \\
\text { (m) }\end{array}$ & $\begin{array}{l}\text { 生活型 } \\
\text { Life form }\end{array}$ & $\begin{array}{l}\text { 分布型 } \\
\text { Areal-type }\end{array}$ & 参考文献 Reference \\
\hline $\begin{array}{l}\text { 毛莨科 } \\
\text { Ranunculaceae }\end{array}$ & 翠雀属 Delphinium & D. beesianum W. W. Sm. & 云南中甸 Zhongdian, Yunnan & & 16 & 8 & $2 \mathrm{x}$ & & $\mathrm{PH}$ & NT & Yuan \& Yang, 2008 \\
\hline $\begin{array}{l}\text { 毛莨科 } \\
\text { Ranunculaceae }\end{array}$ & 翠雀属 Delphinium & D. beesianum W. W. Sm. & 云南中甸 Zhongdian, Yunnan & & 16 & 8 & $2 \mathrm{x}$ & & $\mathrm{PH}$ & NT & 杨亲二, 2001a \\
\hline $\begin{array}{l}\text { 毛莨科 } \\
\text { Ranunculaceae }\end{array}$ & 翠雀属 Delphinium & D. bonvalotii Franch. & 四川木里 Muli, Sichuan & & 16 & 8 & $2 \mathrm{x}$ & & $\mathrm{PH}$ & NT & 杨亲二, 2001a \\
\hline $\begin{array}{l}\text { 毛茛科 } \\
\text { Ranunculaceae }\end{array}$ & 翠雀属 Delphinium & D. bulleyanum Forrest ex Diels & 云南中甸 Zhongdian, Yunnan & & 16 & 8 & $2 \mathrm{x}$ & & $\mathrm{PH}$ & NT & 杨亲二, 2001a \\
\hline $\begin{array}{l}\text { 毛茛科 } \\
\text { Ranunculaceae }\end{array}$ & 翠雀属 Delphinium & D. bulleyanum G. Forrest ex Diels & 云南中甸 Zhongdian, Yunnan & & 16 & 8 & $2 \mathrm{x}$ & & $\mathrm{PH}$ & NT & Yuan \& Yang, 2008 \\
\hline $\begin{array}{l}\text { 毛莨科 } \\
\text { Ranunculaceae }\end{array}$ & 翠雀属 Delphinium & D. caeruleum Jacquem. ex Cambess. & 四川康定 Kangding, Sichuan & & 16 & 8 & $2 \mathrm{x}$ & & $\mathrm{PH}$ & NT & Yuan \& Yang, 2008 \\
\hline $\begin{array}{l}\text { 毛茛科 } \\
\text { Ranunculaceae }\end{array}$ & 翠雀属 Delphinium & D. caeruleum Jacquem. ex Cambess. & 四川松潘 Songpan, Sichuan & & 16 & 8 & $2 x$ & & PH & NT & Yuan \& Yang, 2008 \\
\hline $\begin{array}{l}\text { 毛莨科 } \\
\text { Ranunculaceae }\end{array}$ & 翠雀属 Delphinium & D. caeruleum Jacquem. ex Cambess. & Zoige, Sichuan & & 16 & 8 & $2 \mathrm{x}$ & & $\mathrm{PH}$ & NT & Yuan \& Yang, 2008 \\
\hline $\begin{array}{l}\text { 毛莨科 } \\
\text { Ranunculaceae }\end{array}$ & 翠雀属 Delphinium & D. caeruleum Jacquem. & 四川若尔盖 Ruoergai, Sichuan & & 16 & 8 & $2 \mathrm{x}$ & & $\mathrm{PH}$ & NT & 杨亲二, 1996 \\
\hline $\begin{array}{l}\text { 毛莨科 } \\
\text { Ranunculaceae }\end{array}$ & 翠雀属 Delphinium & D. campylocentrum Maxim. & 四川红原 Hongyuan, Sichuan & & 16 & 8 & $2 \mathrm{x}$ & & $\mathrm{PH}$ & NT & Yuan \& Yang, 2008 \\
\hline $\begin{array}{l}\text { 毛莨科 } \\
\text { Ranunculaceae }\end{array}$ & 翠雀属 Delphinium & $\begin{array}{l}\text { D. candelabrum var. monanthum } \\
\text { (Hand. -Mazz.) W. T. Wang }\end{array}$ & $\begin{array}{l}\text { 青海祁连县冰沟大坂 Binggou, } \\
\text { Qilian, Qinghai }\end{array}$ & & 16 & 8 & $2 \mathrm{x}$ & 4,200 & $\mathrm{PH}$ & NT & $\begin{array}{l}\text { 黄荣福和沈颂东, } \\
1999\end{array}$ \\
\hline 毛茛科 & 翠雀属 Delphinium & D. candelabrum var. monanthum & 青海玉树 Yushu, Qinghai & & 16 & 8 & $2 \mathrm{x}$ & 4,650 & $\mathrm{PH}$ & NT & 刘建全和何廷农, \\
\hline
\end{tabular}


王家坚, 彭智邦, 孙航, 聂泽龙, 孟盈. 青藏高原与横断山被子植物区系演化的细胞地理学特征. 生物多样性, 2017, 25 (2): 218-225.

http://www.biodiversity-science.net/CN/10.17520/biods.2016281

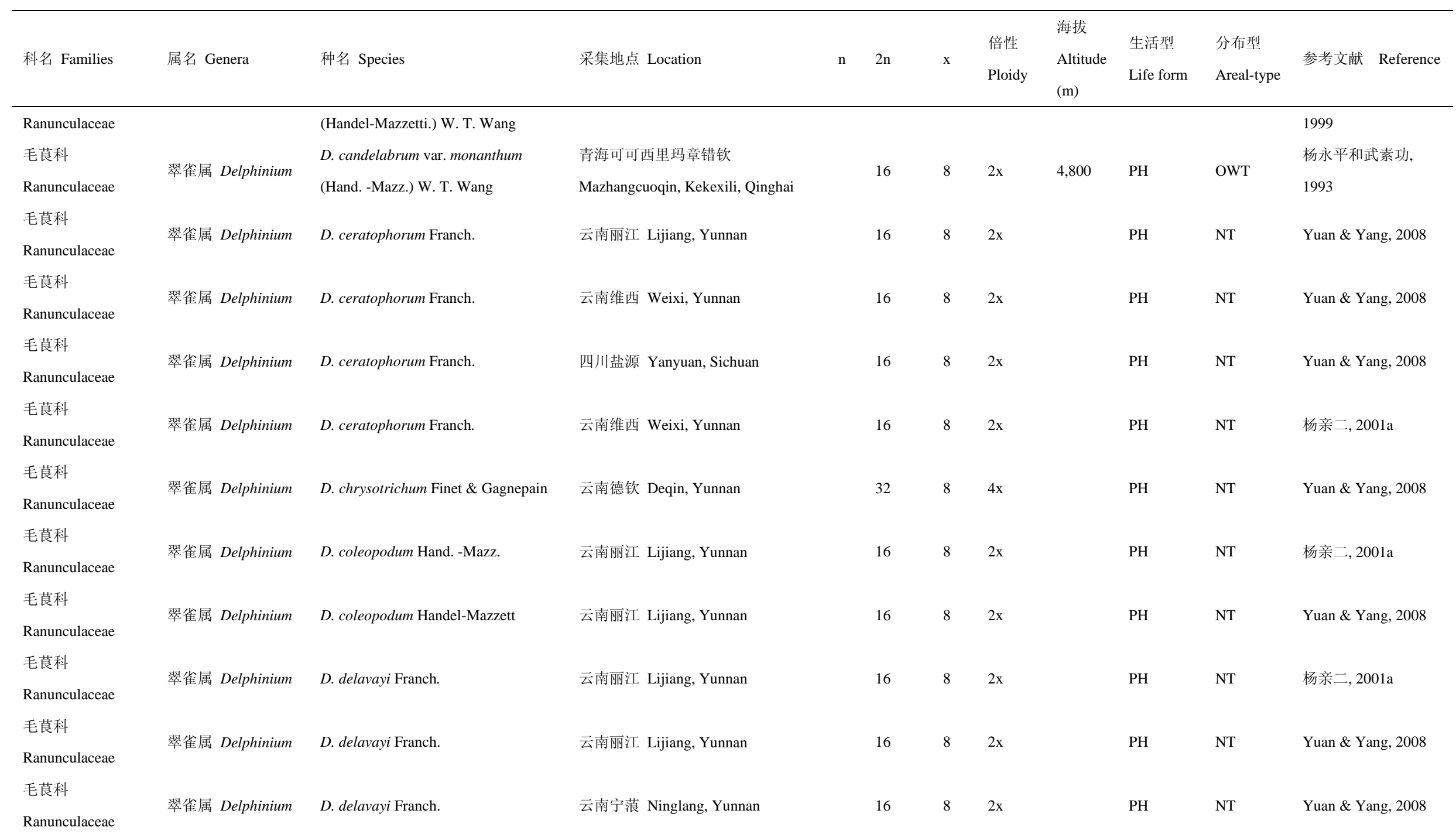


王家坚, 彭智邦, 孙航, 聂泽龙, 孟盈. 青藏高原与横断山被子植物区系演化的细胞地理学特征. 生物多样性, 2017, 25 (2): 218-225.

http://www.biodiversity-science.net/CN/10.17520/biods.2016281

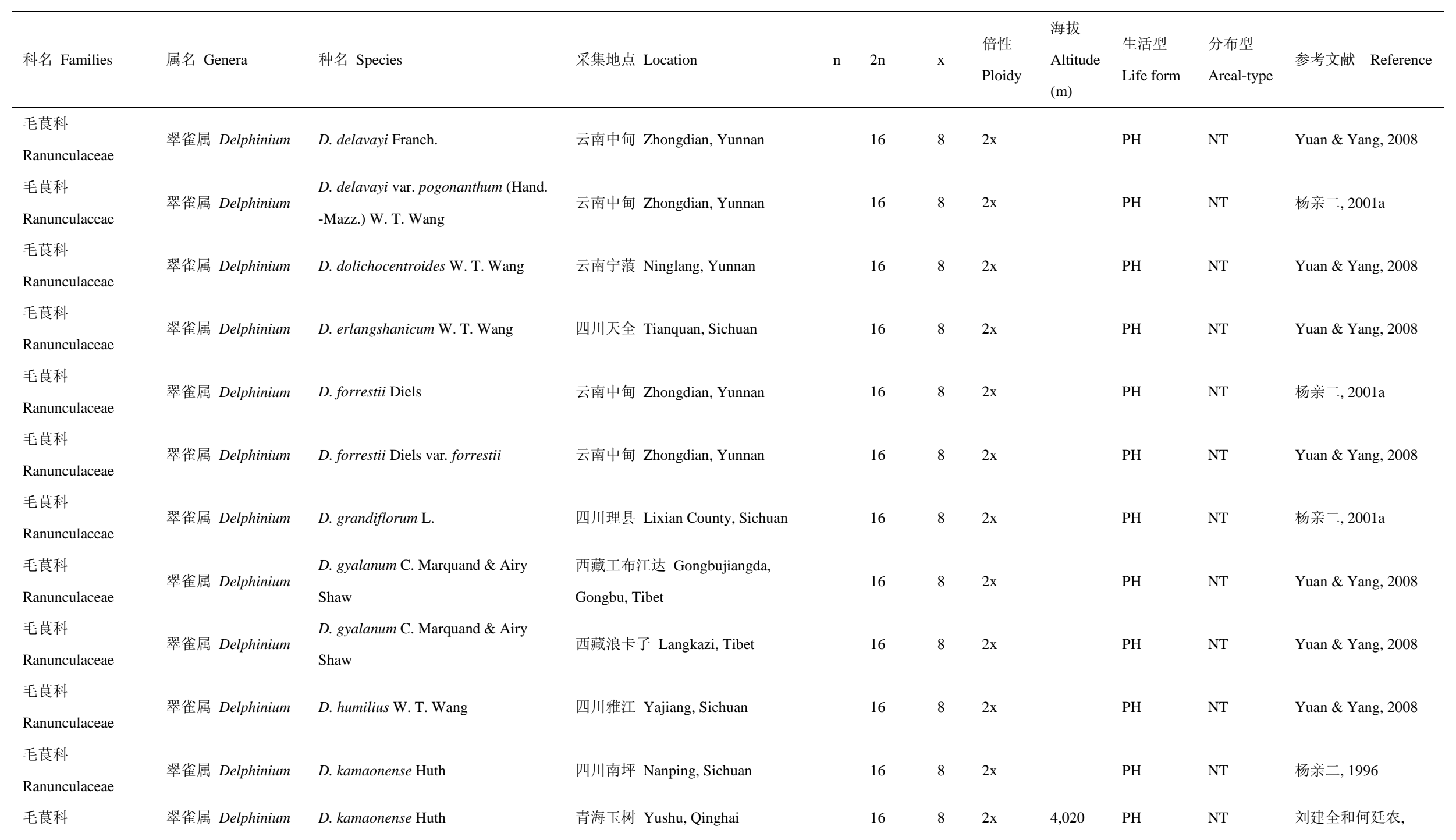


王家坚, 彭智邦, 孙航, 聂泽龙, 孟盈. 青藏高原与横断山被子植物区系演化的细胞地理学特征. 生物多样性, 2017, 25 (2): 218-225.

http://www.biodiversity-science.net/CN/10.17520/biods.2016281

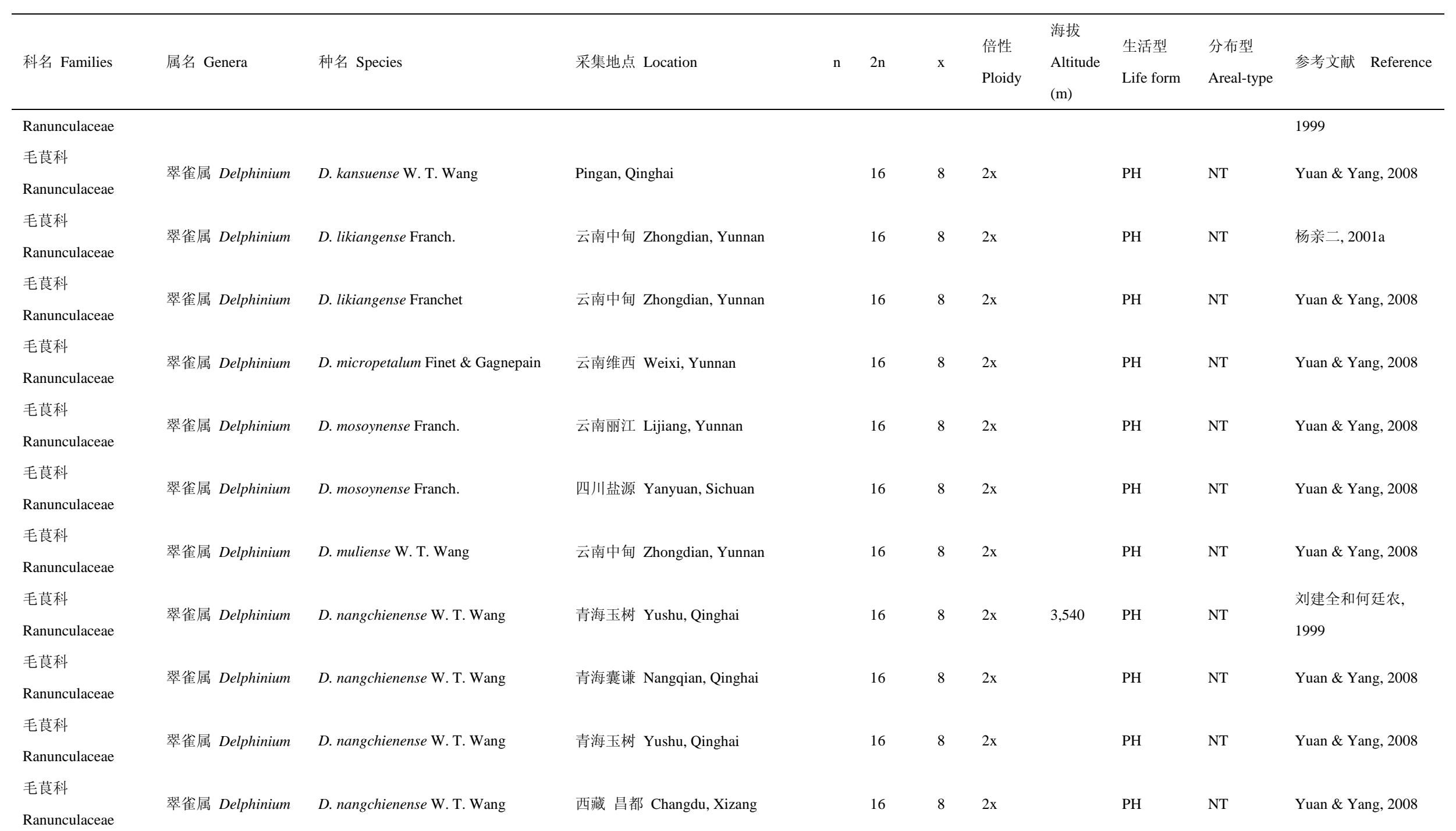


王家坚, 彭智邦, 孙航, 聂泽龙, 孟盈. 青藏高原与横断山被子植物区系演化的细胞地理学特征. 生物多样性, 2017, 25 (2): 218-225.

http://www.biodiversity-science.net/CN/10.17520/biods.2016281

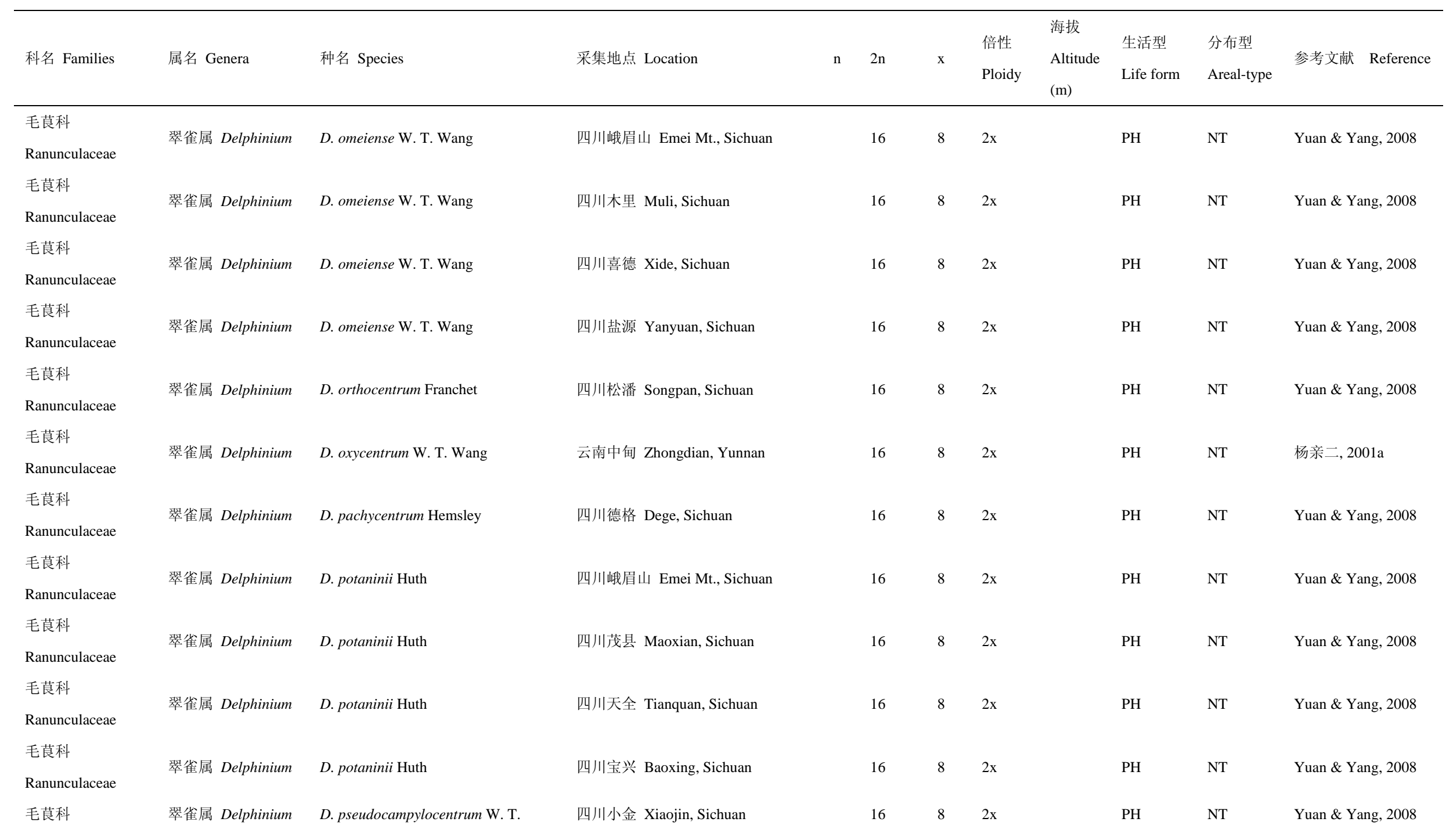


王家坚, 彭智邦, 孙航, 聂泽龙, 孟盈. 青藏高原与横断山被子植物区系演化的细胞地理学特征. 生物多样性, 2017, 25 (2): 218-225.

http://www.biodiversity-science.net/CN/10.17520/biods.2016281

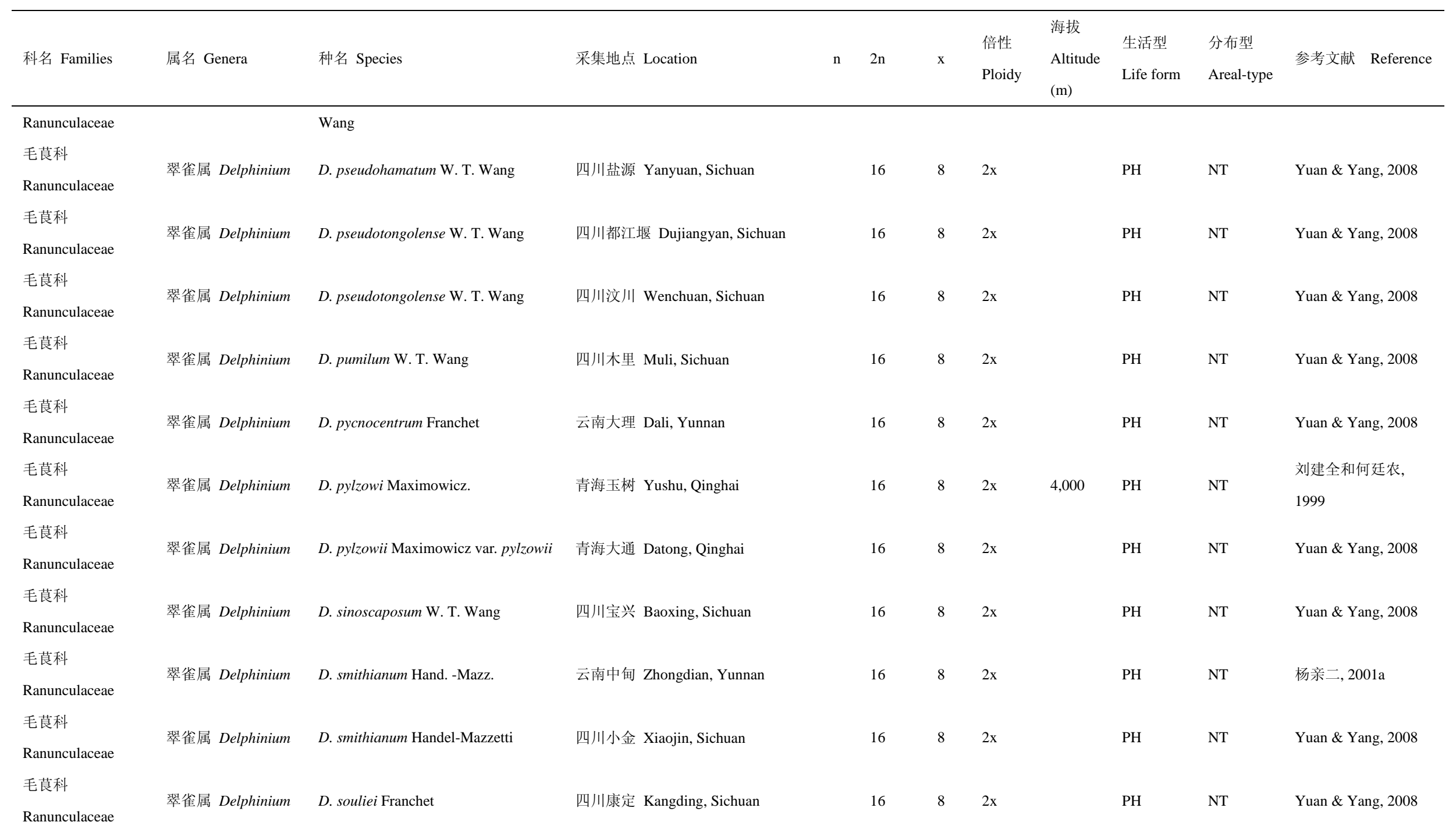


王家坚, 彭智邦, 孙航, 聂泽龙, 孟盈. 青藏高原与横断山被子植物区系演化的细胞地理学特征. 生物多样性, 2017, 25 (2): 218-225.

http://www.biodiversity-science.net/CN/10.17520/biods.2016281

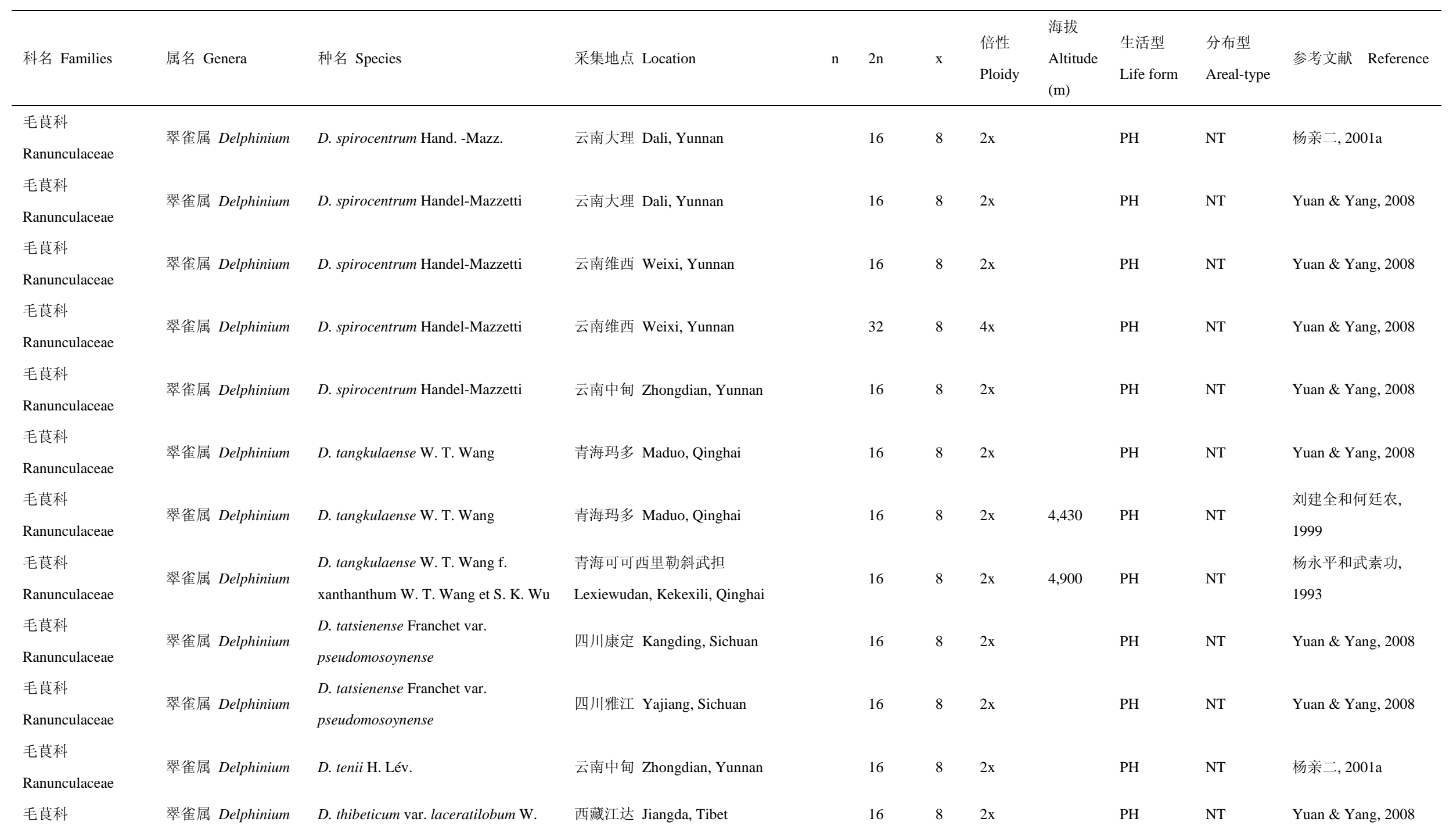


王家坚, 彭智邦, 孙航, 聂泽龙, 孟盈. 青藏高原与横断山被子植物区系演化的细胞地理学特征. 生物多样性, 2017, 25 (2): 218-225.

http://www.biodiversity-science.net/CN/10.17520/biods.2016281

\begin{tabular}{|c|c|c|c|c|c|c|c|c|c|c|c|}
\hline 科名 Families & 属名 Genera & 种名 Species & 采集地点 Location & $\mathrm{n}$ & $2 \mathrm{n}$ & $\mathrm{x}$ & $\begin{array}{l}\text { 倍性 } \\
\text { Ploidy }\end{array}$ & $\begin{array}{l}\text { 海拔 } \\
\text { Altitude } \\
\text { (m) }\end{array}$ & $\begin{array}{l}\text { 生活型 } \\
\text { Life form }\end{array}$ & $\begin{array}{l}\text { 分布型 } \\
\text { Areal-type }\end{array}$ & 参考文献 Reference \\
\hline Ranunculaceae & & T. Wang & & & & & & & & & \\
\hline $\begin{array}{l}\text { 毛莨科 } \\
\text { Ranunculaceae }\end{array}$ & 翠雀属 Delphinium & D. tongolense Franchet & 四川雅江 Yajiang, Sichuan & & 16 & 8 & $2 \mathrm{x}$ & & PH & NT & Yuan \& Yang, 2008 \\
\hline $\begin{array}{l}\text { 毛莨科 } \\
\text { Ranunculaceae }\end{array}$ & 翠雀属 Delphinium & $\begin{array}{l}\text { D. trichophorum var. subglaberrimum } \\
\text { Hand. -Mazz. }\end{array}$ & 四川康定 Kangding, Sichuan & & 16 & 8 & $2 \mathrm{x}$ & & PH & NT & Yuan \& Yang, 2008 \\
\hline $\begin{array}{l}\text { 毛莨科 } \\
\text { Ranunculaceae }\end{array}$ & 翠雀属 Delphinium & $\begin{array}{l}\text { D. trichophorum var. trichophorum } \\
\text { Franch. }\end{array}$ & 四川小金 Xiaojin, Sichuan & & 16 & 8 & $2 \mathrm{x}$ & & PH & NT & Yuan \& Yang, 2008 \\
\hline $\begin{array}{l}\text { 毛莨科 } \\
\text { Ranunculaceae }\end{array}$ & 翠雀属 Delphinium & $\begin{array}{l}\text { D. trichophorum var. trichophorum } \\
\text { Franch. }\end{array}$ & 青海玉树 Yushu, Qinghai & & 16 & 8 & $2 \mathrm{x}$ & & PH & NT & Yuan \& Yang, 2008 \\
\hline $\begin{array}{l}\text { 毛莨科 } \\
\text { Ranunculaceae }\end{array}$ & 翠雀属 Delphinium & $\begin{array}{l}\text { D. trichophorum var. trichophorum } \\
\text { Franch. }\end{array}$ & 青海泽库 Zeku, Qinghai & & 16 & 8 & $2 \mathrm{x}$ & & $\mathrm{PH}$ & NT & Yuan \& Yang, 2008 \\
\hline $\begin{array}{l}\text { 毛莨科 } \\
\text { Ranunculaceae }\end{array}$ & 翠雀属 Delphinium & D. umbrosum Hand. -Mazz. & 云南维西 Weixi, Yunnan & & 16 & 8 & $2 \mathrm{x}$ & & $\mathrm{PH}$ & NT & 杨亲二, 2001a \\
\hline $\begin{array}{l}\text { 毛莨科 } \\
\text { Ranunculaceae }\end{array}$ & 翠雀属 Delphinium & D. umbrosum Handel-Mazzetti & 云南维西 Weixi, Yunnan & & 16 & 8 & $2 \mathrm{x}$ & & $\mathrm{PH}$ & NT & Yuan \& Yang, 2008 \\
\hline $\begin{array}{l}\text { 毛莨科 } \\
\text { Ranunculaceae }\end{array}$ & 翠雀属 Delphinium & D. wardii C. Marquand \& Airy Shaw & 西藏林芝 Linzhi, Tibet & & 16 & 8 & $2 \mathrm{x}$ & & PH & NT & Yuan \& Yang, 2008 \\
\hline
\end{tabular}


王家坚, 彭智邦, 孙航, 聂泽龙, 孟盈. 青藏高原与横断山被子植物区系演化的细胞地理学特征. 生物多样性, 2017, 25 (2): 218-225.

http://www.biodiversity-science.net/CN/10.17520/biods.2016281

\begin{tabular}{|c|c|c|c|c|c|c|c|c|c|c|c|}
\hline 科名 Families & 属名 Genera & 种名 Species & 采集地点 Location & $\mathrm{n}$ & $2 n$ & $\mathrm{x}$ & $\begin{array}{l}\text { 倍性 } \\
\text { Ploidy }\end{array}$ & $\begin{array}{l}\text { 海拔 } \\
\text { Altitude } \\
\text { (m) }\end{array}$ & $\begin{array}{l}\text { 生活型 } \\
\text { Life form }\end{array}$ & $\begin{array}{l}\text { 分布型 } \\
\text { Areal-type }\end{array}$ & 参考文献 Reference \\
\hline $\begin{array}{l}\text { 毛莨科 } \\
\text { Ranunculaceae }\end{array}$ & 侧金戞花属 Adonis & A. brevistyla Franch. & 云南中甸 Zhongdian, Yunnan & & 16 & 8 & $2 \mathrm{x}$ & & $\mathrm{PH}$ & OWT & 杨亲二, 2001b \\
\hline $\begin{array}{l}\text { 毛莨科 } \\
\text { Ranunculaceae }\end{array}$ & 侧金盛花属 Adonis & A. coerulea Maxim & $\begin{array}{l}\text { 青海可可西里察日措 Charicuo, } \\
\text { Kekexili, Qinghai }\end{array}$ & & 24 & 6 & $4 \mathrm{x}$ & 4,800 & $\mathrm{AH}$ & $\mathrm{C}$ & $\begin{array}{l}\text { 杨永平和武素功, } \\
1993\end{array}$ \\
\hline $\begin{array}{l}\text { 毛莨科 } \\
\text { Ranunculaceae }\end{array}$ & $\begin{array}{l}\text { 美花草属 } \\
\text { Callianthemum }\end{array}$ & $\begin{array}{l}\text { C. pimpinelloides (D. Don) Hook. f. \& } \\
\text { Thoms. }\end{array}$ & 云南中甸 Zhongdian, Yunnan & & 32 & 16 & $4 \mathrm{x}$ & & $\mathrm{PH}$ & OWT & 杨亲二, 2001b \\
\hline $\begin{array}{l}\text { 毛莨科 } \\
\text { Ranunculaceae }\end{array}$ & $\begin{array}{l}\text { 美花草属 } \\
\text { Callianthemum }\end{array}$ & C. pimpinelloides Hook. f. et Thoms. & $\begin{array}{l}\text { 青海可可西里乌兰乌拉湖 } \\
\text { Wulanwula Lake, Kekexili, Qinghai }\end{array}$ & & 14 & 7 & $2 \mathrm{x}$ & 4,800 & $\mathrm{PH}$ & $\mathrm{C}$ & $\begin{array}{l}\text { 杨永平和武素功, } \\
1993\end{array}$ \\
\hline 茜草科 Rubiaceae & 钩毛草属 Kelloggia & K. chinensis (Honglashan) & 四川甘孜 Ganzi, Sichuan & & 34 & 17 & $2 \mathrm{x}$ & 3,400 & $\mathrm{PH}$ & OWT & Tu et al, 2005a \\
\hline 茜草科 Rubiaceae & 钩毛草属 Kelloggia & K. chinensis (Napahai) & 云南中甸 Zhongdian, Yunnan & & 48 & 6 & $8 \mathrm{x}$ & 3,700 & $\mathrm{PH}$ & OWT & Tu et al, 2005a \\
\hline 茜草科 Rubiaceae & 钩毛草属 Kelloggia & K. chinensis (Xialang) & 四川石渠 Shiqu, Sichuan & & 44 & 11 & $4 \mathrm{x}$ & 4,320 & $\mathrm{PH}$ & EC & Tu et al, 2005a \\
\hline 蓄薇科 Rosaceae & 悬钩子属 Rubus & R. amabilis Focke & 四川雅安 Ya'an, Sichuan & & 14 & 7 & $2 \mathrm{x}$ & 1,250 & $\mathrm{~W}$ & $\mathrm{C}$ & 王小蓉等, 2008 \\
\hline 蓄薇科 Rosaceae & 悬钩子属 Rubus & R. assamensis Focke & 四川雅安 Ya’an, Sichuan & & 28 & 7 & $4 \mathrm{x}$ & 700 & $\mathrm{~W}$ & $\mathrm{C}$ & 王小蓉等, 2008 \\
\hline 蓄薇科 Rosaceae & 悬钩子属 Rubus & R. buergeri Miq. & 四川雅安 Ya'an, Sichuan & & 56 & 7 & $8 \mathrm{x}$ & 850 & $\mathrm{~W}$ & $\mathrm{C}$ & 王小蓉等, 2008 \\
\hline 蓄薇科 Rosaceae & 悬钩子属 Rubus & R. caudifolius Wuzhi & 四川雅安 Ya'an, Sichuan & & 28 & 7 & $4 \mathrm{x}$ & 1,700 & $\mathrm{~W}$ & $\mathrm{C}$ & 王小蓉等, 2008 \\
\hline 蓄薇科 Rosaceae & 悬钩子属 Rubus & R. cockburnianus Hemsl. & 四川天全 Tianquan, Sichuan & & 14 & 7 & $2 \mathrm{x}$ & 1,800 & $\mathrm{~W}$ & $\mathrm{C}$ & 王小蓉等, 2008 \\
\hline 蓄薇科 Rosaceae & 悬钩子属 Rubus & R. corchorifolius L. f. & 四川雅安 Ya’an, Sichuan & & 14 & 7 & $2 \mathrm{x}$ & 750 & $\mathrm{~W}$ & $\mathrm{C}$ & 王小蓉等, 2008 \\
\hline 蓄薇科 Rosaceae & 悬钩子属 Rubus & R. coreanus Miq. & 四川雅安 Ya’an, Sichuan & & 14 & 7 & $2 \mathrm{x}$ & 680 & $\mathrm{~W}$ & $\mathrm{C}$ & 王小蓉等, 2008 \\
\hline 蓄薇科 Rosaceae & 悬钩子属 Rubus & R. ellipticus Smith & 四川雅安 Ya'an, Sichuan & & 14 & 7 & $2 \mathrm{x}$ & 750 & $\mathrm{~W}$ & $\mathrm{C}$ & 王小蓉等, 2008 \\
\hline 蓄薇科 Rosaceae & 悬钩子属 Rubus & $\begin{array}{l}\text { R. ellipticus var.obcordatus (Franch.) } \\
\text { Focke }\end{array}$ & 四川雅安 Ya’an, Sichuan & & 14 & 7 & $2 \mathrm{x}$ & 700 & $\mathrm{~W}$ & $\mathrm{C}$ & 王小蓉等, 2008 \\
\hline 蓄薇科 Rosaceae & 悬钩子属 Rubus & R. faberi Focke & 四川峨眉山 Emei Mt., Sichuan & & 28 & 7 & $4 \mathrm{x}$ & 660 & $\mathrm{~W}$ & $\mathrm{C}$ & 王小蓉等, 2008 \\
\hline 蓄薇科 Rosaceae & 悬钩子属 Rubus & R. hirsutus Thunb. & 四川龙泉 Longquan, Sichuan & & 14 & 7 & $2 \mathrm{x}$ & 700 & $\mathrm{~W}$ & $\mathrm{C}$ & 王小蓉等, 2008 \\
\hline
\end{tabular}


王家坚, 彭智邦, 孙航, 聂泽龙, 孟盈. 青藏高原与横断山被子植物区系演化的细胞地理学特征. 生物多样性, 2017, 25 (2): 218-225.

http://www.biodiversity-science.net/CN/10.17520/biods.2016281

\begin{tabular}{|c|c|c|c|c|c|c|c|c|c|c|c|}
\hline 科名 Families & 属名 Genera & 种名 Species & 采集地点 Location & $\mathrm{n}$ & $2 n$ & $\mathrm{x}$ & $\begin{array}{l}\text { 倍性 } \\
\text { Ploidy }\end{array}$ & $\begin{array}{l}\text { 海拔 } \\
\text { Altitude } \\
\text { (m) }\end{array}$ & $\begin{array}{l}\text { 生活型 } \\
\text { Life form }\end{array}$ & $\begin{array}{l}\text { 分布型 } \\
\text { Areal-type }\end{array}$ & 参考文献 Reference \\
\hline 蓄薇科 Rosaceae & 悬钩子属 Rubus & R. ichangensis Hemsl. \& Ktze. & 四川雅安 Ya'an, Sichuan & & 28 & 7 & $4 \mathrm{x}$ & 700 & $\mathrm{~W}$ & $\mathrm{C}$ & 王小蓉等, 2008 \\
\hline 蓄薇科 Rosaceae & 悬钩子属 Rubus & R. ichangensis Hemsl. \& Kuntze & 四川峨眉山 Emei Mt., Sichuan & & 28 & 14 & $4 \mathrm{x}$ & & $\mathrm{W}$ & $\mathrm{C}$ & $\begin{array}{l}\text { Iwatsubo \& } \\
\text { Naruhashi, } 1992\end{array}$ \\
\hline 蓄薇科 Rosaceae & 悬钩子属 Rubus & R. idaeopsis Focke & 四川西充 Xichong, Sichuan & & 21 & 7 & $3 \mathrm{x}$ & 700 & $\mathrm{~W}$ & $\mathrm{C}$ & 王小蓉等, 2008 \\
\hline 菩薇科 Rosaceae & 悬钩子属 Rubus & R. innominatus S. Moore & 四川天全 Tianquan, Sichuan & & 14 & 7 & $2 \mathrm{x}$ & 2,000 & $\mathrm{~W}$ & $\mathrm{C}$ & 王小蓉等, 2008 \\
\hline 菩薇科 Rosaceae & 悬钩子属 Rubus & R. inopertus (Diels) Focke & 四川雅安 Ya’an, Sichuan & & 14 & 7 & $2 \mathrm{x}$ & 1,740 & $\mathrm{~W}$ & $\mathrm{C}$ & 王小蓉等, 2008 \\
\hline 蓄薇科 Rosaceae & 悬钩子属 Rubus & R. lambertianus var. glaber Hemsl. & 四川雅安 Ya’an, Sichuan & & 28 & 7 & $4 \mathrm{x}$ & 680 & $\mathrm{~W}$ & $\mathrm{C}$ & 王小蓉等, 2008 \\
\hline 蓄薇科 Rosaceae & 悬钩子属 Rubus & R. mesogaeus Focke & 四川峨眉山 Emei Mt., Sichuan & & 14 & 7 & $2 \mathrm{x}$ & 1,670 & $\mathrm{~W}$ & $\mathrm{C}$ & 王小蓉等, 2008 \\
\hline 蓄薇科 Rosaceae & 悬钩子属 Rubus & R. niveus Thunb. & 四川雅安 Ya'an, Sichuan & & 14 & 7 & $2 \mathrm{x}$ & 700 & $\mathrm{~W}$ & C & 王小蓉等, 2008 \\
\hline 蓄薇科 Rosaceae & 悬钩子属 Rubus & R. parkeri Hance & 四川雅安 Ya’an, Sichuan & & 28 & 7 & $4 \mathrm{x}$ & 680 & $\mathrm{~W}$ & $\mathrm{C}$ & 王小蓉等, 2008 \\
\hline 蓄薇科 Rosaceae & 悬钩子属 Rubus & R. parvifolius L. & 四川西充 Xichong, Sichuan & & 14 & 7 & $2 \mathrm{x}$ & 550 & $\mathrm{~W}$ & $\mathrm{C}$ & 王小蓉等, 2008 \\
\hline 蓄薇科 Rosaceae & 悬钩子属 Rubus & R. parvifolius L. & 四川西充 Xichong, Sichuan & & 28 & 7 & $4 \mathrm{x}$ & 550 & $\mathrm{~W}$ & C & 王小蓉等, 2008 \\
\hline 蓄薇科 Rosaceae & 悬钩子属 Rubus & R. pinfaensis Lévl. \& Vant. & 四川峨眉山 Emei Mt., Sichuan & & 14 & 7 & $2 \mathrm{x}$ & 850 & $\mathrm{~W}$ & $\mathrm{C}$ & 王小蓉等, 2008 \\
\hline 蓄薇科 Rosaceae & 悬钩子属 Rubus & R. pungens Camb. & 四川天全 Tianquan, Sichuan & & 14 & 7 & $2 \mathrm{x}$ & 2,100 & $\mathrm{~W}$ & $\mathrm{C}$ & 王小蓉等, 2008 \\
\hline 蓄薇科 Rosaceae & 悬钩子属 Rubus & R. setchuenensis Bureau \& Franch. & 四川天全 Tianquan, Sichuan & & 28 & 7 & $4 \mathrm{x}$ & 2,000 & $\mathrm{~W}$ & $\mathrm{C}$ & 王小蓉等, 2008 \\
\hline 蓄薇科 Rosaceae & 悬钩子属 Rubus & R. stans Focke & 四川西昌 Xichang, Sichuan & & 14 & 7 & $2 \mathrm{x}$ & 2,100 & $\mathrm{~W}$ & $\mathrm{C}$ & 王小蓉等, 2008 \\
\hline 蓄薇科 Rosaceae & 悬钩子属 Rubus & R. subinopertus Yü \& Lu & 四川峨眉山 Emei Mt., Sichuan & & 14 & 7 & $2 \mathrm{x}$ & 2,150 & $\mathrm{~W}$ & $\mathrm{C}$ & 王小蓉等, 2008 \\
\hline 蓄薇科 Rosaceae & 悬钩子属 Rubus & R. subtibetanus Hand. -Mazz. & 四川峨眉山 Emei Mt., Sichuan & & 14 & 7 & $2 \mathrm{x}$ & 2,450 & $\mathrm{~W}$ & $\mathrm{C}$ & 王小蓉等, 2008 \\
\hline 蓄薇科 Rosaceae & 悬钩子属 Rubus & R. yiwuanus Fang & 四川雅安 Ya’an, Sichuan & & 28 & 7 & $4 \mathrm{x}$ & 1,700 & $\mathrm{~W}$ & $\mathrm{C}$ & 王小蓉等, 2008 \\
\hline 蓄薇科 Rosaceae & 绣线菊属 Spiraea & S. japonica var. acuminata & 四川南川 Nanchuan, Sichuan & & 18 & 9 & $2 \mathrm{x}$ & & $\mathrm{W}$ & NT & Zhang et al, 2002 \\
\hline 蓄薇科 Rosaceae & 绣线菊属 Spiraea & S. japonica var. acuta & 云南大理 Dali, Yunnan & & 18 & 9 & $2 \mathrm{x}$ & & $\mathrm{W}$ & NT & Zhang et al, 2002 \\
\hline 蓄薇科 Rosaceae & 绣线菊属 Spiraea & S. japonica var. fortunei & 四川 南川 Nanchuan, Sichuan & & 36 & 9 & $4 \mathrm{x}$ & & $\mathrm{W}$ & NT & Zhang et al, 2002 \\
\hline 蓄薇科 Rosaceae & 绣线菊属 Spiraea & S. japonica var. incisa & 云南维西 Weixi, Yunnan & & 18 & 9 & $2 \mathrm{x}$ & & $\mathrm{W}$ & NT & Zhang et al, 2002 \\
\hline
\end{tabular}


王家坚, 彭智邦, 孙航, 聂泽龙, 孟盈. 青藏高原与横断山被子植物区系演化的细胞地理学特征. 生物多样性, 2017, 25 (2): 218-225.

http://www.biodiversity-science.net/CN/10.17520/biods.2016281

\begin{tabular}{|c|c|c|c|c|c|c|c|c|c|c|c|}
\hline 科名 Families & 属名 Genera & 种名 Species & 采集地点 Location & $\mathrm{n}$ & $2 n$ & $\mathrm{x}$ & $\begin{array}{l}\text { 倍性 } \\
\text { Ploidy }\end{array}$ & $\begin{array}{l}\text { 海拔 } \\
\text { Altitude } \\
\text { (m) }\end{array}$ & $\begin{array}{l}\text { 生活型 } \\
\text { Life form }\end{array}$ & $\begin{array}{l}\text { 分布型 } \\
\text { Areal-type }\end{array}$ & 参考文献 Reference \\
\hline 蓄薇科 Rosaceae & 萻薇属 Rosa & $\begin{array}{l}\text { R. odorata (Andr.) Sweet } \\
\text { var.erubescens }\end{array}$ & 云南维西永春 Weixi, Yunnan & & 21 & 7 & $3 x$ & 2,568 & W & NT & 塞洪英等, 2010 \\
\hline 蓄薇科 Rosaceae & 蓄薇属 Rosa & $\begin{array}{l}\text { R. odorata (Andr.) Sweet var. } \\
\text { erubescens }\end{array}$ & $\begin{array}{l}\text { 云南丽江木家桥 Mujiaqiao, Lijiang, } \\
\text { Yunnan }\end{array}$ & & 21 & 7 & $3 \mathrm{x}$ & 2,420 & $\mathrm{~W}$ & NT & 寒洪英等, 2010 \\
\hline 蓄薇科 Rosaceae & 蓄薇属 Rosa & $\begin{array}{l}\text { R. odorata (Andr.) Sweet var. } \\
\text { pseudoindica }\end{array}$ & $\begin{array}{l}\text { 云南丽江新主 Xinzhu, Lijiang, } \\
\text { Yunnan }\end{array}$ & & 14 & 7 & $2 \mathrm{x}$ & 2,346 & $\mathrm{~W}$ & NT & 寒洪英等, 2010 \\
\hline 蓄薇科 Rosaceae & 苹果属 Malus & M. asiatica Nakai & 四川巴县 Baxian, Sichuan & & 68 & 17 & $4 \mathrm{x}$ & & $\mathrm{W}$ & NT & 梁国鲁, 1987 \\
\hline 蓄薇科 Rosaceae & 苹果属 Malus & M. halliana Koehne & 四川昭觉 Zhaojue, Sichuan & & 34 & 17 & $2 \mathrm{x}$ & & $\mathrm{W}$ & NT & $\begin{array}{l}\text { 梁国鲁和李晓林, } \\
1993\end{array}$ \\
\hline 蓄薇科 Rosaceae & 苹果属 Malus & M. halliana Koehne & 四川昭觉 Zhaojue, Sichuan & & 34 & 17 & $2 \mathrm{x}$ & & $\mathrm{W}$ & NT & 梁国鲁, 1987 \\
\hline 蓄薇科 Rosaceae & 苹果属 Malus & M. hupehensis (Pampanini) Rehder & 四川马尔康 Maerkang, Sichuan & & 51 & 17 & $3 \mathrm{x}$ & & $\mathrm{W}$ & NT & 梁国鲁, 1987 \\
\hline 蓄薇科 Rosaceae & 苹果属 Malus & M. hupehensis (Pampanini) Rehder & 四川盐源 Yanyuan, Sichuan & & 68 & 17 & $4 \mathrm{x}$ & & $\mathrm{W}$ & NT & 梁国鲁, 1987 \\
\hline 蓄薇科 Rosaceae & 苹果属 Malus & $\begin{array}{l}\text { M. kansuensis (Batalin) C. K. } \\
\text { Schneid. }\end{array}$ & 四川小金 Xiaojin, Sichuan & & 34 & 17 & $2 x$ & & W & NT & 梁国鲁, 1987 \\
\hline 蓄薇科 Rosaceae & 苹果属 Malus & M. ombrophila Handel-Mazzetti & 四川盐源 Yanyuan, Sichuan & & 34 & 17 & $2 \mathrm{x}$ & & $\mathrm{W}$ & NT & $\begin{array}{l}\text { 梁国鲁和李晓林, } \\
1993\end{array}$ \\
\hline 蓄薇科 Rosaceae & 苹果属 Malus & M. ombrophila Handel-Mazzetti & 四川盐源 Yanyuan, Sichuan & & 34 & 17 & $2 \mathrm{x}$ & & $\mathrm{W}$ & NT & 梁国鲁, 1987 \\
\hline 蓄薇科 Rosaceae & 苹果属 Malus & M. rockii Rehder & 四川盐源 Yanyuan, Sichuan & & 34 & 17 & $2 \mathrm{x}$ & & $\mathrm{W}$ & NT & $\begin{array}{l}\text { 梁国鲁和李晓林, } \\
1993\end{array}$ \\
\hline 蓄薇科 Rosaceae & 苹果属 Malus & M. rockii Rehder & 四川盐源 Yanyuan, Sichuan & & 34 & 17 & $2 \mathrm{x}$ & & $\mathrm{W}$ & NT & 梁国鲁, 1987 \\
\hline 蓄薇科 Rosaceae & 苹果属 Malus & M. rockii Rehder & 四川昭觉 Zhaojue, Sichuan & & 51 & 17 & $3 \mathrm{x}$ & & $\mathrm{W}$ & NT & $\begin{array}{l}\text { 梁国鲁和李晓林, } \\
1993\end{array}$ \\
\hline 蓄薇科 Rosaceae & 苹果属 Malus & M. rockii Rehder & 四川昭觉 Zhaojue, Sichuan & & 51 & 17 & $3 x$ & & $\mathrm{~W}$ & NT & 梁国鲁, 1987 \\
\hline
\end{tabular}


王家坚, 彭智邦, 孙航, 聂泽龙, 孟盈. 青藏高原与横断山被子植物区系演化的细胞地理学特征. 生物多样性, 2017, 25 (2): 218-225.

http://www.biodiversity-science.net/CN/10.17520/biods.2016281

\begin{tabular}{|c|c|c|c|c|c|c|c|c|c|c|c|}
\hline 科名 Families & 属名 Genera & 种名 Species & 采集地点 Location & $\mathrm{n}$ & $2 n$ & $\mathrm{x}$ & $\begin{array}{l}\text { 倍性 } \\
\text { Ploidy }\end{array}$ & $\begin{array}{l}\text { 海拔 } \\
\text { Altitude } \\
\text { (m) }\end{array}$ & $\begin{array}{l}\text { 生活型 } \\
\text { Life form }\end{array}$ & $\begin{array}{l}\text { 分布型 } \\
\text { Areal-type }\end{array}$ & 参考文献 Reference \\
\hline 蓄薇科 Rosaceae & 苹果属 Malus & $\begin{array}{l}\text { M. sikkimensis (Wenzig) Koehne ex } \\
\text { C. K. Schneid. }\end{array}$ & 四川盐源 Yanyuan, Sichuan & & 34 & 17 & $2 \mathrm{x}$ & & $\mathrm{W}$ & NT & $\begin{array}{l}\text { 梁国鲁和李晓林, } \\
1993\end{array}$ \\
\hline 蓄薇科 Rosaceae & 苹果属 Malus & M. toringoides (Rehd.) Hughes & 四川阿坝 Aba, Sichuan & & 34 & 17 & $2 \mathrm{x}$ & & $\mathrm{W}$ & NT & $\begin{array}{l}\text { 梁国鲁和李晓林, } \\
1993\end{array}$ \\
\hline 蓄薇科 Rosaceae & 苹果属 Malus & M. toringoides (Rehd.) Hughes & 四川阿坝 Aba, Sichuan & & 68 & 17 & $4 \mathrm{x}$ & & W & NT & $\begin{array}{l}\text { 梁国鲁和李晓林, } \\
1993\end{array}$ \\
\hline 蓄薇科 Rosaceae & 苹果属 Malus & M. toringoides (Rehd.) Hughes & 四川马尔康 Maerkang, Sichuan & & 51 & 17 & $3 x$ & & $\mathrm{~W}$ & NT & $\begin{array}{l}\text { 梁国鲁和李晓林, } \\
1993\end{array}$ \\
\hline 蓄薇科 Rosaceae & 苹果属 Malus & M. toringoides (Rehder) Hughes & 四川马尔康 Maerkang, Sichuan & & 51 & 17 & $3 \mathrm{x}$ & & $\mathrm{W}$ & NT & 梁国鲁, 1987 \\
\hline 蓄薇科 Rosaceae & 苹果属 Malus & M. transitoria (Batalin) C.K. Schneid. & 四川阿坝 Aba, Sichuan & & 34 & 17 & $2 \mathrm{x}$ & & $\mathrm{W}$ & NT & 肖艳等, 1997 \\
\hline 蓄薇科 Rosaceae & 苹果属 Malus & $\begin{array}{l}\text { M. transitoria (Batalin) C. K. } \\
\text { Schneid. }\end{array}$ & 四川阿坝 Aba, Sichuan & & 51 & 17 & $3 x$ & & W & NT & 肖艳等, 1997 \\
\hline 蓄薇科 Rosaceae & 苹果属 Malus & $\begin{array}{l}\text { M. xiaojinensis M. H. Cheng \& N. G. } \\
\text { Jiang }\end{array}$ & 四川小金 Xiaojin, Sichuan & & 68 & 17 & $4 \mathrm{x}$ & & W & NT & $\begin{array}{l}\text { 梁国鲁和李晓林, } \\
1993\end{array}$ \\
\hline 蓄薇科 Rosaceae & 苹果属 Malus & $\begin{array}{l}\text { M. yunnanensis (Franchetet) C. K. } \\
\text { Schneider }\end{array}$ & 四川盐源 Yanyuan, Sichuan & & 34 & 17 & $2 \mathrm{x}$ & & $\mathrm{W}$ & NT & $\begin{array}{l}\text { 梁国鲁和李晓林, } \\
1993\end{array}$ \\
\hline 蓄薇科 Rosaceae & 苹果属 Malus & $\begin{array}{l}\text { M. yunnanensis (Franchetet) C. K. } \\
\text { Schneider }\end{array}$ & 四川盐源 Yanyuan, Sichuan & & 34 & 17 & $2 \mathrm{x}$ & & $\mathrm{W}$ & NT & 梁国鲁, 1987 \\
\hline 蓄薇科 Rosaceae & $\begin{array}{l}\text { 牛筋条属 } \\
\text { Dichotomanthes }\end{array}$ & D. tristaniaecarpa Kurz & 云南腾冲 Tengchong, Yunnan & & 34 & 17 & $2 \mathrm{x}$ & & $\mathrm{W}$ & EC & Zhou et al, 2000a \\
\hline 蓄薇科 Rosaceae & 花楸属 Sorbus & S. Koehneana C. K. Schneider & 云南德钦 Deqin, Yunnan & & 34 & 17 & $2 \mathrm{x}$ & & $\mathrm{W}$ & NT & 陈丹, 2014 \\
\hline 蓄薇科 Rosaceae & 花楸属 Sorbus & $\begin{array}{l}\text { S. setschwanensis (C. K. Schneider) } \\
\text { Koehne }\end{array}$ & $\begin{array}{l}\text { 四川峨眉山雷洞坪 Leidongping, } \\
\text { Emei Mt., Sichuan }\end{array}$ & & 34 & 17 & $2 x$ & & W & NT & 陈丹, 2014 \\
\hline
\end{tabular}


王家坚, 彭智邦, 孙航, 聂泽龙, 孟盈. 青藏高原与横断山被子植物区系演化的细胞地理学特征. 生物多样性, 2017, 25 (2): 218-225.

http://www.biodiversity-science.net/CN/10.17520/biods.2016281

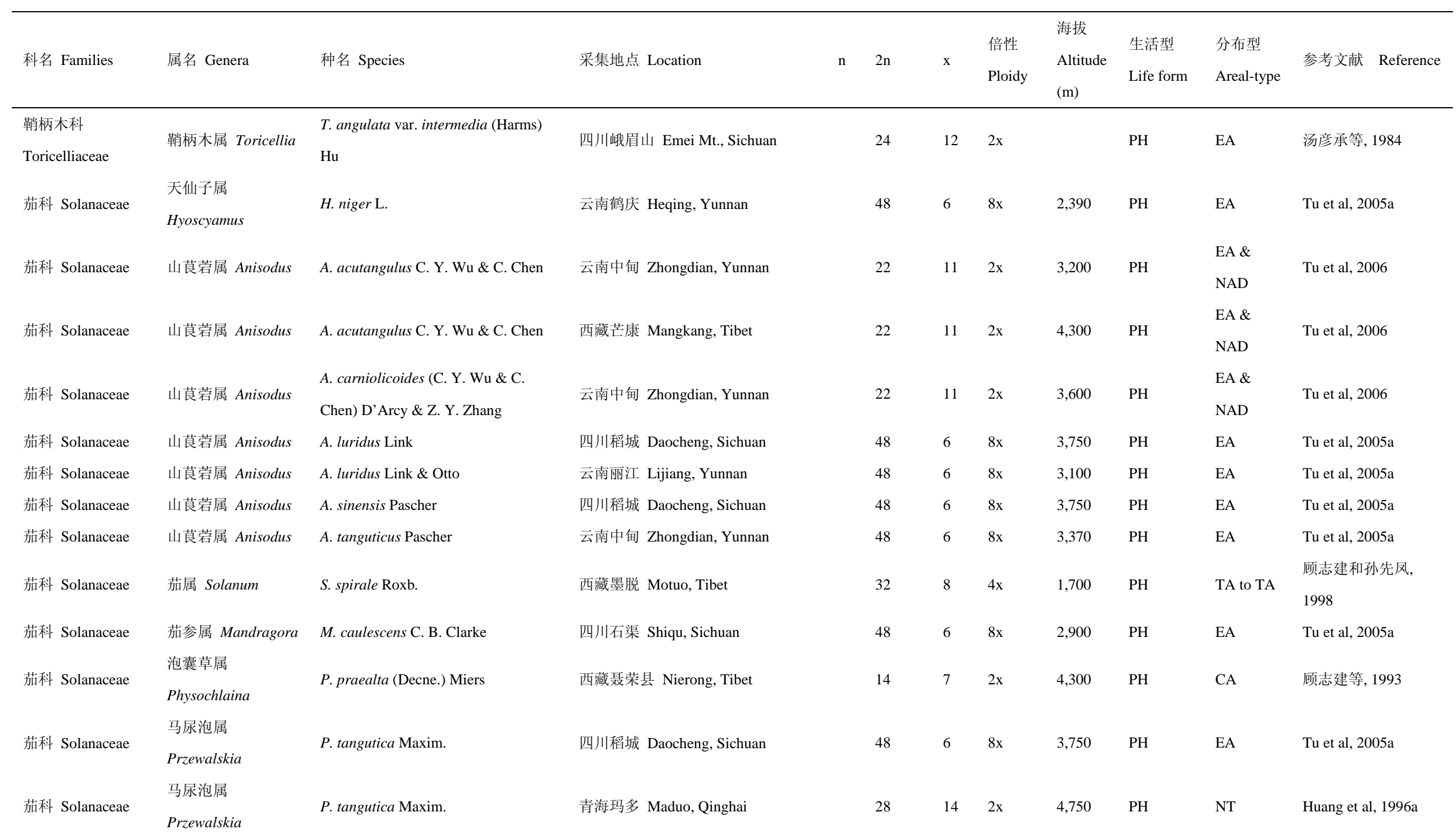


王家坚, 彭智邦, 孙航, 聂泽龙, 孟盈. 青藏高原与横断山被子植物区系演化的细胞地理学特征. 生物多样性, 2017, 25 (2): 218-225.

http://www.biodiversity-science.net/CN/10.17520/biods.2016281

\begin{tabular}{|c|c|c|c|c|c|c|c|c|c|c|c|}
\hline 科名 Families & 属名 Genera & 种名 Species & 采集地点 Location & $\mathrm{n}$ & $2 n$ & $\mathrm{x}$ & $\begin{array}{l}\text { 倍性 } \\
\text { Ploidy }\end{array}$ & $\begin{array}{l}\text { 海拔 } \\
\text { Altitude } \\
\text { (m) }\end{array}$ & $\begin{array}{l}\text { 生活型 } \\
\text { Life form }\end{array}$ & $\begin{array}{l}\text { 分布型 } \\
\text { Areal-type }\end{array}$ & 参考文献 Reference \\
\hline 茄科 Solanaceae & $\begin{array}{l}\text { 高原芥属 } \\
\text { Christolea }\end{array}$ & C. crassifolia Camb & 青海玛多 Maduo, Qinghai & & 14 & 7 & $2 \mathrm{x}$ & 4,300 & PH & NT & 顾志建等, 1993 \\
\hline $\begin{array}{l}\text { 清风藤科 } \\
\text { Sabiaceae }\end{array}$ & 鼠尾草属 Salvia & S. yunnanensis Franch. & 四川峨眉山 Emei Mt., Sichuan & 22 & & 22 & $4 \mathrm{x}$ & 2,100 & $\mathrm{AH}$ & C & Hong \& Zhang, 1990 \\
\hline $\begin{array}{l}\text { 秋海棠科 } \\
\text { Begoniaceae }\end{array}$ & 秋海棠属 Begonia & B. cavaleriei H. Lév. & 云南洱源 Eyuan, Yunnan & & 30 & 10 & $3 \mathrm{x}$ & & PH & $\mathrm{P}$ & 田代科等, 2002 \\
\hline $\begin{array}{l}\text { 忍冬科 } \\
\text { Caprifoliaceae }\end{array}$ & 忍冬属 Lonicera & L. schneideriana Rehder & 四川峨眉山 Emei Mt., Sichuan & & 12 & 6 & $2 \mathrm{x}$ & 1,200 & $\mathrm{AH}$ & EA & Hong \& Zhang, 1990 \\
\hline 伞形科 Apiaceae & 丝瓣芹属 Acronema & A. paniculatum (Franch.) Wolff & 云南宾川 Binchuan, Yunnan & & 18 & 9 & $2 \mathrm{x}$ & 2,200 & PH & C & 张丹等, 2010 \\
\hline 伞形科 Apiaceae & 鼠尾草属 Salvia & S. evansiana Hand. -Mazz. & 云南大理 Dali, Yunnan & & 32 & 16 & $4 \mathrm{x}$ & 2,550 & PH & $\mathrm{C}$ & 赵红霞等, 2006 \\
\hline 伞形科 Apiaceae & 鼠尾草属 Salvia & S. miltiorrhiza Bunge & $\begin{array}{l}\text { 云南昆明西山 Xishan, Kunming, } \\
\text { Yunnan }\end{array}$ & & 16 & 8 & $2 \mathrm{x}$ & 1,891 & PH & C & 赵红霞等, 2006 \\
\hline 伞形科 Apiaceae & $\begin{array}{l}\text { 㒸活属 } \\
\text { Notopterygium }\end{array}$ & N. forbesii Boissieu & 四川马边山 Mabian Mt., Sichuan & & 22 & 11 & $2 \mathrm{x}$ & 2,610 & $\mathrm{PH}$ & EC & 张雪梅等, 2006 \\
\hline 伞形科 Apiaceae & $\begin{array}{l}\text { 㒸活属 } \\
\text { Notopterygium }\end{array}$ & N. forbesii Boissieu & $\begin{array}{l}\text { 四川屏山老君山 Laojun Mt., } \\
\text { Pingshan, Sichuan }\end{array}$ & & 22 & 11 & $2 \mathrm{x}$ & 1,950 & PH & EC & 张雪梅等, 2006 \\
\hline 伞形科 Apiaceae & $\begin{array}{l}\text { 前胡属 } \\
\text { Peucedanum }\end{array}$ & P. songpanense Shan et $\mathrm{Pu}$ & 四川松潘 Songpan, Sichuan & & 22 & 11 & $2 \mathrm{x}$ & 2,900 & PH & OWT & 张雪梅等, 2006 \\
\hline 伞形科 Apiaceae & $\begin{array}{l}\text { 前胡属 } \\
\text { Peucedanum }\end{array}$ & P. turgeniifolium Wolff & 四川松潘 Songpan, Sichuan & & 22 & 11 & $2 \mathrm{x}$ & 2,900 & PH & OWT & 张雪梅等, 2006 \\
\hline 伞形科 Apiaceae & $\begin{array}{l}\text { 迷果芹属 } \\
\text { Sphallerocarpus }\end{array}$ & S. gracilis (Bess.) K-Pol. & 甘肃山丹县 Shandan, Gansu & & 20 & 10 & $2 \mathrm{x}$ & 2,650 & PH & CA & 赵东利等, 2001 \\
\hline 伞形科 Apiaceae & 棱子芹属 & P. angelicoides Benth. ex C. B. Clarke & 云南丽江 Lijiang, Yunnan & & 22 & 11 & $2 \mathrm{x}$ & & PH & OWT & 秦慧贞等, 1989 \\
\hline
\end{tabular}


王家坚, 彭智邦, 孙航, 聂泽龙, 孟盈. 青藏高原与横断山被子植物区系演化的细胞地理学特征. 生物多样性, 2017, 25 (2): 218-225.

http://www.biodiversity-science.net/CN/10.17520/biods.2016281

\begin{tabular}{|c|c|c|c|c|c|c|c|c|c|c|c|}
\hline 科名 Families & 属名 Genera & 种名 Species & 采集地点 Location & $\mathrm{n}$ & $2 n$ & $\mathrm{x}$ & $\begin{array}{l}\text { 倍性 } \\
\text { Ploidy }\end{array}$ & $\begin{array}{l}\text { 海拔 } \\
\text { Altitude } \\
\text { (m) }\end{array}$ & $\begin{array}{l}\text { 生活型 } \\
\text { Life form }\end{array}$ & $\begin{array}{l}\text { 分布型 } \\
\text { Areal-type }\end{array}$ & 参考文献 Reference \\
\hline & Pleurospermum & & & & & & & & & & \\
\hline 伞形科 Apiaceae & $\begin{array}{l}\text { 棱子芹属 } \\
\text { Pleurospermum }\end{array}$ & P. franchetianum Hemsl. & $\begin{array}{l}\text { 四川小金县巴郎山 Balang Mt., } \\
\text { Xiaojin, Sichuan }\end{array}$ & & 18 & 9 & $2 \mathrm{x}$ & 3,900 & PH & OWT & 蒲吉霞等, 2006 \\
\hline 伞形科 Apiaceae & $\begin{array}{l}\text { 棱子芹属 } \\
\text { Pleurospermum }\end{array}$ & P. hookeri var. thomsonii C. B. Clarke & $\begin{array}{l}\text { 四川松潘县黄龙寺 Huanglongsi, } \\
\text { Songpan, Sichuan }\end{array}$ & & 22 & 11 & $2 \mathrm{x}$ & 3,570 & PH & OWT & 蒲吉霞等, 2006 \\
\hline 伞形科 Apiaceae & $\begin{array}{l}\text { 棱子芹属 } \\
\text { Pleurospermum }\end{array}$ & P. permum & $\begin{array}{l}\text { 四川松潘县黄龙寺 Huanglongsi, } \\
\text { Songpan, Sichuan }\end{array}$ & & 22 & 11 & $2 \mathrm{x}$ & 3,570 & $\mathrm{PH}$ & OWT & 蒲吉霞等, 2006 \\
\hline 伞形科 Apiaceae & $\begin{array}{l}\text { 棱子芹属 } \\
\text { Pleurospermum }\end{array}$ & P. permum & $\begin{array}{l}\text { 四川小金县巴郎山 Balang Mt., } \\
\text { Xiaojin, Sichuan }\end{array}$ & & 18 & 9 & $2 \mathrm{x}$ & 3,900 & $\mathrm{PH}$ & OWT & 蒲吉霞等, 2006 \\
\hline 伞形科 Apiaceae & $\begin{array}{l}\text { 棱子芹属 } \\
\text { Pleurospermum }\end{array}$ & $\begin{array}{l}\text { P. rivulorum (Diels) K. T. Fu \& Y. C. } \\
\text { Ho }\end{array}$ & 云南丽江 Lijiang, Yunnan & & 22 & 11 & $2 x$ & & PH & OWT & 秦慧贞等, 1989 \\
\hline 伞形科 Apiaceae & 茴芹属 Pimpinella & P. arguta Diels & $\begin{array}{l}\text { 四川汶川县卧龙 Wolong, } \\
\text { Wenchuan, Sichuan }\end{array}$ & & 22 & 11 & $2 x$ & 2,318 & PH & $\mathrm{C}$ & 蒲吉霞等, 2006 \\
\hline 伞形科 Apiaceae & 茴芹属 Pimpinella & P. candolleana Wight et Arn. & 云南德钦 Deqin, Yunnan & & 18 & 9 & $2 \mathrm{x}$ & 3,462 & PH & $\mathrm{C}$ & 张丹等, 2010 \\
\hline 伞形科 Apiaceae & 茴芹属 Pimpinella & P. diversifolia DC. & 四川茂县 Maoxian, Sichuan & & 18 & 9 & $2 \mathrm{x}$ & 1,470 & $\mathrm{PH}$ & $\mathrm{C}$ & 蒲吉霞等, 2006 \\
\hline 伞形科 Apiaceae & 茴芹属 Pimpinella & P. diversifolia DC. & $\begin{array}{l}\text { 四川汶川县草坡乡 Caopoxiang, } \\
\text { Wenchuan, Sichuan }\end{array}$ & & 18 & 9 & $2 \mathrm{x}$ & 1,800 & PH & C & 蒲吉霞等, 2006 \\
\hline 伞形科 Apiaceae & 茴芹属 Pimpinella & P. diversifolia DC. & $\begin{array}{l}\text { 四川汶川县卧龙 Wolong, } \\
\text { Wenchuan, Sichuan }\end{array}$ & & 18 & 9 & $2 \mathrm{x}$ & 2,080 & PH & $\mathrm{C}$ & 蒲吉霞等, 2006 \\
\hline 伞形科 Apiaceae & 茴芹属 Pimpinella & P. diversifolia DC. & $\begin{array}{l}\text { 四川汶川县银杏 Yinxing, } \\
\text { Wenchuan, Sichuan }\end{array}$ & & 18 & 9 & $2 \mathrm{x}$ & 1,240 & PH & C & 蒲吉霞等, 2006 \\
\hline 伞形科 Apiaceae & 茴芹属 Pimpinella & P. flaccida C. B. Clarke & 云南德钦 Deqin, Yunnan & & 18 & 9 & $2 \mathrm{x}$ & 3,510 & $\mathrm{AH}$ & $\mathrm{C}$ & 张丹等, 2010 \\
\hline 伞形科 Apiaceae & 茴芹属 Pimpinella & P. flaccida C. B. Clarke & 云南宾川 Binchuan, Yunnan & 10 & & 10 & $2 \mathrm{x}$ & & PH & $\mathrm{C}$ & 秦慧贞等, 1989 \\
\hline
\end{tabular}


王家坚, 彭智邦, 孙航, 聂泽龙, 孟盈. 青藏高原与横断山被子植物区系演化的细胞地理学特征. 生物多样性, 2017, 25 (2): 218-225.

http://www.biodiversity-science.net/CN/10.17520/biods.2016281

\begin{tabular}{|c|c|c|c|c|c|c|c|c|c|c|c|}
\hline 科名 Families & 属名 Genera & 种名 Species & 采集地点 Location & $\mathrm{n}$ & $2 n$ & $\mathrm{x}$ & $\begin{array}{l}\text { 倍性 } \\
\text { Ploidy }\end{array}$ & $\begin{array}{l}\text { 海拔 } \\
\text { Altitude } \\
\text { (m) }\end{array}$ & $\begin{array}{l}\text { 生活型 } \\
\text { Life form }\end{array}$ & $\begin{array}{l}\text { 分布型 } \\
\text { Areal-type }\end{array}$ & 参考文献 Reference \\
\hline 伞形科 Apiaceae & 菜本属 Ligusticum & L. acuminatum Franch. & 四川小金 Xiaojin, Sichuan & & 22 & 11 & $2 \mathrm{x}$ & & $\mathrm{PH}$ & NT & 潘泽惠等, 1985 \\
\hline 伞形科 Apiaceae & 菜本属 Ligusticum & L. brachylobum Franch. & 云南鹤庆 Heqing, Yunnan & 11 & & 11 & $2 \mathrm{x}$ & & $\mathrm{PH}$ & NT & 秦慧贞等, 1989 \\
\hline 伞形科 Apiaceae & 菜本属 Ligusticum & L. brachylobum Franch. & 云南香格里拉 Shangri-la, Yunnan & & 22 & 11 & $2 \mathrm{x}$ & 3,500 & PH & NT & Zhou et al, 2008 \\
\hline 伞形科 Apiaceae & 菜本属 Ligusticum & L. capillaceum $\mathrm{H}$. Wolff & 四川稻城 Daocheng, Sichuan & & 44 & 11 & $4 \mathrm{x}$ & 3,740 & $\mathrm{PH}$ & NT & Zhou et al, 2008 \\
\hline 伞形科 Apiaceae & 菜本属 Ligusticum & L. daucoides (Franch.) Franch. & 四川稻城 Daocheng, Sichuan & & 22 & 11 & $2 \mathrm{x}$ & 4,500 & $\mathrm{PH}$ & NT & Zhou et al, 2008 \\
\hline 伞形科 Apiaceae & 菜本属 Ligusticum & L. delavayi Franch. & 云南小中甸 Xiaozhongdian, Yunnan & & 22 & 11 & $2 \mathrm{x}$ & 3,257 & $\mathrm{PH}$ & NT & Zhou et al, 2008 \\
\hline 伞形科 Apiaceae & 菜本属 Ligusticum & L. involucratum Franch & 四川雅江 Yajiang, Sichuan & & 22 & 11 & $2 \mathrm{x}$ & 4,200 & $\mathrm{PH}$ & NT & Zhou et al, 2008 \\
\hline 半形科 Apiaceae & 㩰本属 Ligusticum & L. pteridophyllum Franch. & 云南五峰山 & & 44 & 11 & $4 \mathrm{x}$ & 3,500 & $\mathrm{PH}$ & NT & Zhou et al, 2008 \\
\hline 伞形科 Apiaceae & 菜本属 Ligusticum & L. pteridophyllum Franch. ex Gliver & 云南大理 Dali, Yunnan & 11 & & 11 & $2 \mathrm{x}$ & & $\mathrm{PH}$ & NT & 秦慧贞等, 1989 \\
\hline 伞形科 Apiaceae & 菜本属 Ligusticum & $\begin{array}{l}\text { L. rechingerianum (Leute) R. H. Shan } \\
\text { \& F. D. Pu }\end{array}$ & 云南维西 Weixi, Yunnan & & 22 & 11 & $2 \mathrm{x}$ & 3,400 & $\mathrm{PH}$ & NT & Zhou et al, 2008 \\
\hline 半形科 Apiaceae & 㩰本属 Ligusticum & L. sikiangense Hiroe & 四川稻城 Daocheng, Sichuan & & 22 & 11 & $2 \mathrm{x}$ & 4,500 & $\mathrm{PH}$ & NT & Zhou et al, 2008 \\
\hline 伞形科 Apiaceae & 菜本属 Ligusticum & $\begin{array}{l}\text { L. tenuisectum H.de Bossieu } \\
\text { H. candicans var. obtusifolium }\end{array}$ & 云南丽江 Lijiang, Yunnan & & 22 & 11 & $2 \mathrm{x}$ & 3,100 & $\mathrm{PH}$ & NT & Zhou et al, 2008 \\
\hline 伞形科 Apiaceae & 独活属 Heracleum & $\begin{array}{l}\text { (Wallich } e x \text { de Candolle) F. T. Pu \& } \\
\text { M. F. Watson }\end{array}$ & 四川康定 Kangding, Sichuan & & 22 & 11 & $2 \mathrm{x}$ & 3,100 & $\mathrm{PH}$ & NT & Deng et al, 2009 \\
\hline 伞形科 Apiaceae & 独活属 Heracleum & $\begin{array}{l}\text { H. candicans var. obtusifolium } \\
\text { (Wallich ex de Candolle) F. T. Pu \& } \\
\text { M. F. Watson }\end{array}$ & 四川汶川 Wenchuan, Sichuan & & 22 & 11 & $2 \mathrm{x}$ & 2,100 & PH & NT & Deng et al, 2009 \\
\hline 伞形科 Apiaceae & 独活属 Heracleum & H. candicans Wall. & 四川松潘 Songpan, Sichuan & & 22 & 11 & $2 \mathrm{x}$ & & $\mathrm{PH}$ & NT & 何廷农等, 1994 \\
\hline 伞形科 Apiaceae & 独活属 Heracleum & H. candicans Wall. ex DC. & 四川稻城 Daocheng, Sichuan & & 22 & 11 & $2 \mathrm{x}$ & 3,250 & PH & NT & Deng et al, 2009 \\
\hline 伞形科 Apiaceae & 独活属 Heracleum & H. candicans Wall. ex DC. & 四川理塘 Litang, Sichuan & & 22 & 11 & $2 \mathrm{x}$ & 4,140 & $\mathrm{PH}$ & NT & Deng et al, 2009 \\
\hline 伞形科 Apiaceae & 独活属 Heracleum & H. candicans Wall. ex DC. & 云南中甸 Zhongdian, Yunnan & & 22 & 11 & $2 \mathrm{x}$ & 3,400 & PH & NT & Deng et al, 2009 \\
\hline
\end{tabular}


王家坚, 彭智邦, 孙航, 聂泽龙, 孟盈. 青藏高原与横断山被子植物区系演化的细胞地理学特征. 生物多样性, 2017, 25 (2): 218-225.

http://www.biodiversity-science.net/CN/10.17520/biods.2016281

\begin{tabular}{|c|c|c|c|c|c|c|c|c|c|c|c|}
\hline 科名 Families & 属名 Genera & 种名 Species & 采集地点 Location & $\mathrm{n}$ & $2 n$ & $\mathrm{x}$ & $\begin{array}{l}\text { 倍性 } \\
\text { Ploidy }\end{array}$ & $\begin{array}{l}\text { 海拔 } \\
\text { Altitude } \\
\text { (m) }\end{array}$ & $\begin{array}{l}\text { 生活型 } \\
\text { Life form }\end{array}$ & $\begin{array}{l}\text { 分布型 } \\
\text { Areal-type }\end{array}$ & 参考文献 Reference \\
\hline 伞形科 Apiaceae & 独活属 Heracleum & H. candicans Wall. ex DC. & 四川雅江 Yajiang, Sichuan & & 22 & 11 & $2 \mathrm{x}$ & 3,900 & $\mathrm{PH}$ & NT & Deng et al, 2009 \\
\hline 伞形科 Apiaceae & 独活属 Heracleum & H. franchetii Hiroe & 四川稻城 Daocheng, Sichuan & & 22 & 11 & $2 \mathrm{x}$ & 3,750 & $\mathrm{PH}$ & NT & Deng et al, 2009 \\
\hline 伞形科 Apiaceae & 独活属 Heracleum & H. franchetii Hiroe & 四川康定 Kangding, Sichuan & & 22 & 11 & $2 \mathrm{x}$ & 3,450 & $\mathrm{PH}$ & NT & Deng et al, 2009 \\
\hline 伞形科 Apiaceae & 独活属 Heracleum & H. franchetii Hiroe & 四川理塘 Litang, Sichuan & & 22 & 11 & $2 \mathrm{x}$ & 3,900 & $\mathrm{PH}$ & NT & Deng et al, 2009 \\
\hline 伞形科 Apiaceae & 独活属 Heracleum & H. franchetii Hiroe & 四川雅江 Yajiang, Sichuan & & 22 & 11 & $2 \mathrm{x}$ & 4,000 & PH & NT & Deng et al, 2009 \\
\hline 伞形科 Apiaceae & 独活属 Heracleum & H. franchetii Hiroe & 四川小金 Xiaojin, Sichuan & & 22 & 11 & $2 \mathrm{x}$ & & $\mathrm{PH}$ & NT & 何廷农等, 1994 \\
\hline 伞形科 Apiaceae & 独活属 Heracleum & H. hemsleyanum Diels & 四川康定 Kangding, Sichuan & & 22 & 11 & $2 \mathrm{x}$ & 3,080 & $\mathrm{PH}$ & NT & Deng et al, 2009 \\
\hline 伞形科 Apiaceae & 独活属 Heracleum & H. hemsleyanum Diels & 四川理县 Lixian County, Sichuan & & 22 & 11 & $2 \mathrm{x}$ & & $\mathrm{PH}$ & NT & 何廷农等, 1994 \\
\hline 伞形科 Apiaceae & 独活属 Heracleum & H. henryi H. Wolff & 云南保山 Baoshan, Yunnan & & 22 & 11 & $2 \mathrm{x}$ & 1,514 & $\mathrm{PH}$ & NT & Deng et al, 2009 \\
\hline 伞形科 Apiaceae & 独活属 Heracleum & H. henryi H. Wolff & 云南腾冲 Tengchong, Yunnan & & 44 & 11 & $4 \mathrm{x}$ & 1,447 & $\mathrm{PH}$ & NT & Deng et al, 2009 \\
\hline 伞形科 Apiaceae & 独活属 Heracleum & H. henryi H. Wolff & 云南沪水 Lushui, Yunnan & 22 & & 11 & $4 \mathrm{x}$ & & $\mathrm{PH}$ & NT & 何廷农等, 1994 \\
\hline 伞形科 Apiaceae & 独活属 Heracleum & H. kingdoni H. Wolff & 云南腾冲 Tengchong, Yunnan & & 44 & 11 & $4 \mathrm{x}$ & 1,600 & $\mathrm{PH}$ & NT & Deng et al, 2009 \\
\hline 伞形科 Apiaceae & 独活属 Heracleum & H. millefolium Diels & 四川稻城 Daocheng, Sichuan & & 22 & 11 & $2 \mathrm{x}$ & 3,970 & PH & NT & Deng et al, 2009 \\
\hline 伞形科 Apiaceae & 独活属 Heracleum & H. millefolium Diels & 四川雅江 Yajiang, Sichuan & & 22 & 11 & $2 \mathrm{x}$ & 4,040 & $\mathrm{PH}$ & NT & Deng et al, 2009 \\
\hline 伞形科 Apiaceae & 独活属 Heracleum & H. millefolium Diels & 四川松潘 Songpan, Sichuan & & 22 & 11 & $2 \mathrm{x}$ & & $\mathrm{PH}$ & NT & 何廷农等, 1994 \\
\hline 伞形科 Apiaceae & 独活属 Heracleum & $\begin{array}{l}\text { H. millefolium var. longilobum C. } \\
\text { Norman }\end{array}$ & 四川松潘 Songpan, Sichuan & & 22,24 & 11 & $2 \mathrm{x}$ & & $\mathrm{PH}$ & NT & 何廷农等, 1994 \\
\hline 伞形科 Apiaceae & 独活属 Heracleum & H. moellendorffii Hance & 四川汶川 Wenchuan, Sichuan & & 22 & 11 & $2 \mathrm{x}$ & 2,000 & $\mathrm{PH}$ & NT & Deng et al, 2009 \\
\hline 伞形科 Apiaceae & 独活属 Heracleum & H. obtusifolium Wall. & 四川汶川 Wenchuan, Sichuan & & 22 & 11 & $2 \mathrm{x}$ & & $\mathrm{PH}$ & NT & 何廷农等, 1994 \\
\hline 伞形科 Apiaceae & 独活属 Heracleum & H. souliei H. Boissieu & 四川康定 Kangding, Sichuan & & 22 & 11 & $2 \mathrm{x}$ & 2,750 & PH & NT & Deng et al, 2009 \\
\hline 伞形科 Apiaceae & 独活属 Heracleum & H. souliei H. Boissieu & 四川康定 Kangding, Sichuan & & 22 & 11 & $2 \mathrm{x}$ & 3,750 & PH & NT & Deng et al, 2009 \\
\hline 伞形科 Apiaceae & 独活属 Heracleum & H. stenopterum Diels & 四川稻城 Daocheng, Sichuan & & 22 & 11 & $2 \mathrm{x}$ & 3,800 & $\mathrm{PH}$ & NT & Deng et al, 2009 \\
\hline 伞形科 Apiaceae & 独活属 Heracleum & H. stenopterum Diels & 四川理塘 Litang, Sichuan & & 22 & 11 & $2 \mathrm{x}$ & 3,900 & $\mathrm{PH}$ & NT & Deng et al, 2009 \\
\hline
\end{tabular}


王家坚, 彭智邦, 孙航, 聂泽龙, 孟盈. 青藏高原与横断山被子植物区系演化的细胞地理学特征. 生物多样性, 2017, 25 (2): 218-225.

http://www.biodiversity-science.net/CN/10.17520/biods.2016281

\begin{tabular}{|c|c|c|c|c|c|c|c|c|c|c|c|}
\hline 科名 Families & 属名 Genera & 种名 Species & 采集地点 Location & $\mathrm{n}$ & $2 n$ & $\mathrm{x}$ & $\begin{array}{l}\text { 倍性 } \\
\text { Ploidy }\end{array}$ & $\begin{array}{l}\text { 海拔 } \\
\text { Altitude } \\
\text { (m) }\end{array}$ & $\begin{array}{l}\text { 生活型 } \\
\text { Life form }\end{array}$ & $\begin{array}{l}\text { 分布型 } \\
\text { Areal-type }\end{array}$ & 参考文献 Reference \\
\hline 伞形科 Apiaceae & 独活属 Heracleum & H. stenopterum Diels & 四川松潘 Songpan, Sichuan & & 22 & 11 & $2 \mathrm{x}$ & & $\mathrm{PH}$ & NT & 何廷农等, 1994 \\
\hline 伞形科 Apiaceae & 独活属 Heracleum & H. vicinum H. Boissieu & 四川汶川 Wenchuan, Sichuan & & 22 & 11 & $2 \mathrm{x}$ & & $\mathrm{PH}$ & NT & 何廷农等, 1994 \\
\hline 伞形科 Apiaceae & 独活属 Heracleum & H. wenchuanense F. T. Pu \& X. J. He & 四川汶川 Wenchuan, Sichuan & & 22 & 11 & $2 \mathrm{x}$ & 3,500 & $\mathrm{PH}$ & NT & Deng et al, 2009 \\
\hline 伞形科 Apiaceae & 独活属 Heracleum & H. wolongense F. T. Pu \& X. J. He & 四川汶川 Wenchuan, Sichuan & & 22 & 11 & $2 \mathrm{x}$ & & $\mathrm{PH}$ & NT & 何廷农等, 1994 \\
\hline 伞形科 Apiaceae & 独活属 Heracleum & H. yungningense Hand. -Mazz. & 四川小金 Xiaojin, Sichuan & & 22 & 11 & $2 \mathrm{x}$ & & PH & NT & 何廷农等, 1994 \\
\hline 伞形科 Apiaceae & 独活属 Heracleum & H. yungningense Handel-Mazzetti & 四川稻城 Daocheng, Sichuan & & 22 & 11 & $2 \mathrm{x}$ & 3,590 & $\mathrm{PH}$ & NT & Deng et al, 2009 \\
\hline 伞形科 Apiaceae & 东俄芹属 Tongoloa & T. elata $\mathrm{H}$. Wolff & 云南大理 Dali, Yunnan & 11 & & 11 & $2 \mathrm{x}$ & & $\mathrm{PH}$ & EA & 秦慧贞等, 1989 \\
\hline 伞形科 Apiaceae & $\begin{array}{l}\text { 滇芎属 } \\
\text { Physospermopsis }\end{array}$ & P. rubrinervis (Franch.) C. Norman & 云南丽江 Lijiang, Yunnan & 11 & & 11 & $2 \mathrm{x}$ & & $\mathrm{PH}$ & EA & 秦慧贞等, 1989 \\
\hline 伞形科 Apiaceae & 当归属 Angelica & A. apaensis R. H. Shan \& C. Q. Yuan & $\begin{array}{l}\text { 四川小金县梦笔山 Mengbing Mt., } \\
\text { Xiaojin, Sichuan }\end{array}$ & & 22 & 11 & $2 \mathrm{x}$ & 3,000 & $\mathrm{PH}$ & NT & 张桥英等, 2005 \\
\hline 伞形科 Apiaceae & 当归属 Angelica & A. chinghaiensis Shan ex K. T. Fu & 四川松潘 Songpan, Sichuan & & 44 & 11 & $4 \mathrm{x}$ & 3,500 & $\mathrm{PH}$ & NT & 潘泽惠等, 1991 \\
\hline 伞形科 Apiaceae & 当归属 Angelica & A. dielsii H. Boissieu & 四川松潘 Songpan, Sichuan & & 22 & 11 & $2 \mathrm{x}$ & 3,000 & $\mathrm{PH}$ & NT & 潘泽惠等, 1991 \\
\hline 伞形科 Apiaceae & 当归属 Angelica & A. laxifoliata Diels & 四川汉源 Hanyuan, Sichuan & & 22 & 11 & $2 \mathrm{x}$ & 1,900 & $\mathrm{PH}$ & NT & 潘泽惠等, 1991 \\
\hline 伞形科 Apiaceae & 当归属 Angelica & A. laxifoliata Diels & $\begin{array}{l}\text { 四川冕宁县石灰窑 Shihuiku, } \\
\text { Mianning, Sichuan }\end{array}$ & & 22 & 11 & $2 \mathrm{x}$ & 2,500 & $\mathrm{PH}$ & NT & 张桥英等, 2005 \\
\hline 伞形科 Apiaceae & 当归属 Angelica & A. laxifoliata Diels & $\begin{array}{l}\text { 四川汶川县巴郎山 Balang Mt., } \\
\text { Wenchuan, Sichuan }\end{array}$ & & 22 & 11 & $2 \mathrm{x}$ & 3,400 & $\mathrm{PH}$ & NT & 张桥英等, 2005 \\
\hline 伞形科 Apiaceae & 当归属 Angelica & $\begin{array}{l}\text { A. maowenensis C. Q. Yuan \& R. H. } \\
\text { Shan }\end{array}$ & 四川松潘 Songpan, Sichuan & & 22 & 11 & $2 \mathrm{x}$ & 2,800 & $\mathrm{PH}$ & NT & 潘泽惠等, 1991 \\
\hline 伞形科 Apiaceae & 当归属 Angelica & A. maowenensis Yuan et Shan & $\begin{array}{l}\text { 四川汶川县巴郎山 Balang Mt., } \\
\text { Wenchuan, Sichuan }\end{array}$ & & 22 & 11 & $2 \mathrm{x}$ & 3,500 & $\mathrm{PH}$ & NT & 张桥英等, 2005 \\
\hline 伞形科 Apiaceae & 当归属 Angelica & A. omeiensis C. C. Yuan \& R. H. Shan & Xiangxiangling, Mianning, Sichuan & & 22 & 11 & $2 \mathrm{x}$ & 4,500 & PH & NT & 张桥英等, 2005 \\
\hline
\end{tabular}


王家坚, 彭智邦, 孙航, 聂泽龙, 孟盈. 青藏高原与横断山被子植物区系演化的细胞地理学特征. 生物多样性, 2017, 25 (2): 218-225.

http://www.biodiversity-science.net/CN/10.17520/biods.2016281

\begin{tabular}{|c|c|c|c|c|c|c|c|c|c|c|c|}
\hline 科名 Families & 属名 Genera & 种名 Species & 采集地点 Location & $\mathrm{n}$ & $2 n$ & $\mathrm{x}$ & $\begin{array}{l}\text { 倍性 } \\
\text { Ploidy }\end{array}$ & $\begin{array}{l}\text { 海拔 } \\
\text { Altitude } \\
\text { (m) }\end{array}$ & $\begin{array}{l}\text { 生活型 } \\
\text { Life form }\end{array}$ & $\begin{array}{l}\text { 分布型 } \\
\text { Areal-type }\end{array}$ & 参考文献 Reference \\
\hline 半形科 Apiaceae & 当归属 Angelica & $\begin{array}{l}\text { A. omeiensis C. Q. Yuan \& R. H. } \\
\text { Shan }\end{array}$ & 四川峨眉山 Emei Mt., Sichuan & & 22 & 11 & $2 \mathrm{x}$ & 2,100 & $\mathrm{PH}$ & NT & 潘泽惠等, 1991 \\
\hline 伞形科 Apiaceae & 当归属 Angelica & A. pseudoselinum de Boiss. & 四川平武 Pingwu, Sichuan & & 22 & 11 & $2 \mathrm{x}$ & 3,050 & PH & NT & 张桥英等, 2005 \\
\hline 伞形科 Apiaceae & 当归属 Angelica & A. setchuenensis Diels & 四川松潘 Songpan, Sichuan & & 22 & 11 & $2 \mathrm{x}$ & 2,800 & $\mathrm{PH}$ & NT & 潘泽惠等, 1991 \\
\hline 伞形科 Apiaceae & 当归属 Angelica & A. sinensis (Oliv.) Diels & 四川松潘 Songpan, Sichuan & & 22 & 11 & $2 \mathrm{x}$ & 2,900 & $\mathrm{PH}$ & NT & 潘泽惠等, 1991 \\
\hline 伞形科 Apiaceae & 当归属 Angelica & A. sinensis (Oliv.) Diels & 四川平武 Pingwu, Sichuan & & 22 & 11 & $2 \mathrm{x}$ & 3,100 & $\mathrm{PH}$ & NT & 张桥英等, 2005 \\
\hline 伞形科 Apiaceae & 柴胡属 Bupleurum & B. angustissimum (Franch.) Kitag. & 青海互助 Huzhu, Qinghai & & 12 & 6 & $2 \mathrm{x}$ & 2,100 & $\mathrm{PH}$ & NT & 梁乾隆等, 2013 \\
\hline 半形科 Apiaceae & 柴胡属 Bupleurum & B. chaishoui Shan et Sheh & 四川茂县 Maoxian, Sichuan & & 12 & 6 & $2 \mathrm{x}$ & 1,730 & $\mathrm{PH}$ & NT & 梁乾隆等, 2013 \\
\hline 伞形科 Apiaceae & 柴胡属 Bupleurum & B. commelynoideum de Boiss. & 云南香格里拉 Shangri-la, Yunnan & & 28 & 7 & $4 \mathrm{x}$ & 3,600 & $\mathrm{PH}$ & NT & 梁乾隆等, 2013 \\
\hline 伞形科 Apiaceae & 柴胡属 Bupleurum & B. commelynoideum de Boiss. & 四川乡城 Xiangcheng, Sichuan & & 12 & 6 & $2 \mathrm{x}$ & 4,370 & PH & NT & 梁乾隆等, 2013 \\
\hline 伞形科 Apiaceae & 柴胡属 Bupleurum & B. commelynoideum var. flaviflorum & 四川松潘 Songpan, Sichuan & & 14 & 7 & $2 \mathrm{x}$ & 2,810 & $\mathrm{PH}$ & NT & 梁乾隆等, 2013 \\
\hline 伞形科 Apiaceae & 柴胡属 Bupleurum & B. condensatum Shan et $\mathrm{Y}$. Li & 青海共和 Gonghe, Qinghai & & 12 & 6 & $2 \mathrm{x}$ & 3,250 & $\mathrm{PH}$ & NT & 梁乾隆等, 2013 \\
\hline 伞形科 Apiaceae & 柴胡属 Bupleurum & $\begin{array}{l}\text { B. longicaule Wall. ex DC. var. } \\
\text { amplexicaule }\end{array}$ & 云南香格里拉 Shangri-la, Yunnan & & 16 & 8 & $2 \mathrm{x}$ & 3,270 & $\mathrm{PH}$ & NT & 梁乾隆等, 2013 \\
\hline 伞形科 Apiaceae & 柴胡属 Bupleurum & $\begin{array}{l}\text { B. marginatum var. stenophyllum } \\
\text { (Wolff) Shan \& Y. Li }\end{array}$ & 云南鹤庆 Heqing, Yunnan & 7 & & 7 & $2 \mathrm{x}$ & & $\mathrm{PH}$ & NT & 秦慧贞等, 1989 \\
\hline 伞形科 Apiaceae & 柴胡属 Bupleurum & B. marginatum Wall. ex DC. & 西藏拉萨 Lhasa, Tibet & & 16 & 8 & $2 \mathrm{x}$ & 3,800 & $\mathrm{PH}$ & NT & 梁乾隆等, 2013 \\
\hline 半形科 Apiaceae & 柴胡属 Bupleurum & B. microcephalum Diels & 四川理县 Lixian County, Sichuan & & 12 & 6 & $2 \mathrm{x}$ & 2,750 & $\mathrm{PH}$ & NT & 梁乾隆等, 2013 \\
\hline 伞形科 Apiaceae & 柴胡属 Bupleurum & B. microcephalum Diels & 四川马尔康 Maerkang, Sichuan & & 12 & 6 & $2 \mathrm{x}$ & 2,816 & $\mathrm{PH}$ & NT & 梁乾隆等, 2013 \\
\hline 伞形科 Apiaceae & 柴胡属 Bupleurum & B. microcephalum Diels & 四川马尔康 Maerkang, Sichuan & & 12 & 6 & $2 \mathrm{x}$ & 2,840 & $\mathrm{PH}$ & NT & 梁乾隆等, 2013 \\
\hline 伞形科 Apiaceae & 柴胡属 Bupleurum & B. petiolulatum Franch. & 云南香格里拉 Shangri-la, Yunnan & & 16 & 8 & $2 \mathrm{x}$ & 3,180 & $\mathrm{PH}$ & NT & 梁乾隆等, 2013 \\
\hline 伞形科 Apiaceae & 柴胡属 Bupleurum & B. petiolulatum var. tenerum & 四川红原 Hongyuan, Sichuan & & 12 & 6 & $2 \mathrm{x}$ & 3,610 & $\mathrm{PH}$ & NT & 梁乾隆等, 2013 \\
\hline 伞形科 Apiaceae & 柴胡属 Bupleurum & B. smithii Wolff var. parvifolium & 青海共和 Gonghe, Qinghai & & 14 & 7 & $2 \mathrm{x}$ & 3,253 & $\mathrm{PH}$ & NT & 梁乾隆等, 2013 \\
\hline
\end{tabular}


王家坚, 彭智邦, 孙航, 聂泽龙, 孟盈. 青藏高原与横断山被子植物区系演化的细胞地理学特征. 生物多样性, 2017, 25 (2): 218-225.

http://www.biodiversity-science.net/CN/10.17520/biods.2016281

\begin{tabular}{|c|c|c|c|c|c|c|c|c|c|c|c|}
\hline 科名 Families & 属名 Genera & 种名 Species & 采集地点 Location & $\mathrm{n}$ & $2 n$ & $\mathrm{x}$ & $\begin{array}{l}\text { 倍性 } \\
\text { Ploidy }\end{array}$ & $\begin{array}{l}\text { 海拔 } \\
\text { Altitude } \\
\text { (m) }\end{array}$ & $\begin{array}{l}\text { 生活型 } \\
\text { Life form }\end{array}$ & $\begin{array}{l}\text { 分布型 } \\
\text { Areal-type }\end{array}$ & 参考文献 Reference \\
\hline 伞形科 Apiaceae & $\begin{array}{l}\text { 糙果芹属 } \\
\text { Trachyspermum }\end{array}$ & $\begin{array}{l}\text { T. scaberulum (Franch.) H.Wolff var. } \\
\text { ambrosiifolium (Franch.) R. H. Shan }\end{array}$ & 云南宾川 Binchuan, Yunnan & 9 & & 9 & $2 \mathrm{x}$ & & $\mathrm{PH}$ & TA to TA & 秦慧贞等, 1989 \\
\hline 山茶科 Theaceae & 山茶属 Camellia & C. pitardii Cohen Stuart & 四川会理 Huili, Sichuan & & 30 & 15 & $2 \mathrm{x}$ & 2,150 & $\mathrm{~W}$ & TA & 顾志建和孙航, 1997 \\
\hline 山茶科 Theaceae & 山茶属 Camellia & C. reticulata Lindl. & 四川渡口 Dukou, Sichuan & & 90 & 15 & $6 \mathrm{x}$ & 2,000 & $\mathrm{~W}$ & TA & 肖调江等, 1996 \\
\hline 山茶科 Theaceae & 山茶属 Camellia & C. reticulata Lindl. & 四川会理 Huili, Sichuan & & 30 & 15 & $2 \mathrm{x}$ & & $\mathrm{W}$ & $\mathrm{TA}$ & 肖调江等, 1996 \\
\hline 山茶科 Theaceae & 山茶属 Camellia & C. reticulata Lindl. & 四川会理 Huili, Sichuan & & 60 & 15 & $4 \mathrm{x}$ & & $\mathrm{W}$ & TA & 肖调江等, 1996 \\
\hline 山茶科 Theaceae & 山茶属 Camellia & C. reticulata Lindl. & 云南华坪 Huaping, Yunnan & & 90 & 15 & $6 \mathrm{x}$ & 1,900 & $\mathrm{~W}$ & TA & 顾志建和孙航, 1997 \\
\hline 山茶科 Theaceae & 山茶属 Camellia & C. reticulata Lindl. & 云南滕冲 Tengchong, Yunnan & & 90 & 15 & $6 \mathrm{x}$ & & $\mathrm{W}$ & $\mathrm{TA}$ & 顾志建等, 1988 \\
\hline 山茶科 Theaceae & 山茶属 Camellia & C. reticulata Lindl. & 云南腾冲 Tengchong, Yunnan & 45 & & 15 & $6 \mathrm{x}$ & & $\mathrm{W}$ & TA & 顾志建等, 1988 \\
\hline 山茶科 Theaceae & 山茶属 Camellia & C. reticulata Lindl. & 云南腾冲 Tengchong, Yunnan & 45 & & 15 & $6 \mathrm{x}$ & & $\mathrm{W}$ & TA & 肖调江等, 1993 \\
\hline 山茶科 Theaceae & 山茶属 Camellia & C. reticulata Lindl. & 四川米易 Miyi, Sichuan & & 90 & 15 & $6 \mathrm{x}$ & 1,850 & $\mathrm{~W}$ & $\mathrm{TA}$ & 顾志建和孙航, 1997 \\
\hline 山茶科 Theaceae & 山茶属 Camellia & C. reticulata Lindl. & 四川攀枝花 Panzhihua, Sichuan & & 90 & 15 & $6 \mathrm{x}$ & 1,700 & $\mathrm{~W}$ & $\mathrm{TA}$ & 顾志建和孙航, 1997 \\
\hline 山茶科 Theaceae & 山茶属 Camellia & C. reticulata Lindl. & 四川延边 Yanbian, Sichuan & & 30 & 15 & $2 \mathrm{x}$ & 2,600 & $\mathrm{~W}$ & $\mathrm{TA}$ & 顾志建和孙航, 1997 \\
\hline 山茶科 Theaceae & 山茶属 Camellia & C. reticulata Lindl. & 四川延边 Yanbian, Sichuan & & 60 & 15 & $4 \mathrm{x}$ & 1,650 & $\mathrm{~W}$ & $\mathrm{TA}$ & 顾志建和孙航, 1997 \\
\hline 山茶科 Theaceae & 山茶属 Camellia & C. reticulata Lindl. & 四川延边 Yanbian, Sichuan & & 30 & 15 & $2 \mathrm{x}$ & & $\mathrm{W}$ & $\mathrm{TA}$ & 夏丽芳等, 1994 \\
\hline 山茶科 Theaceae & 山茶属 Camellia & C. saluenensis Stapf ex Bean & 云南保山 Baoshan, Yunnan & 15 & & 15 & $2 \mathrm{x}$ & & $\mathrm{W}$ & TA & 肖调江等, 1993 \\
\hline 山茶科 Theaceae & 山茶属 Camellia & C. saluenensis Stapf ex Bean & 四川会理 Huili, Sichuan & & 30 & 15 & $2 \mathrm{x}$ & 1,800 & $\mathrm{~W}$ & $\mathrm{TA}$ & 顾志建和孙航, 1997 \\
\hline $\begin{array}{l}\text { 山毛榉科 } \\
\text { Fagaceae }\end{array}$ & $\begin{array}{l}\text { 三棱栎属 } \\
\text { Trigonobalanus }\end{array}$ & T. doichangensis (Camus) Forman & 四川九龙 Jiulong, Sichuan & & 14 & 7 & $2 \mathrm{x}$ & 1,060 & $\mathrm{~W}$ & TA & $\begin{array}{l}\text { 韩春艳和孙卫邦, } \\
2005\end{array}$ \\
\hline $\begin{array}{l}\text { 山毛榉科 } \\
\text { Fagaceae }\end{array}$ & $\begin{array}{l}\text { 三棱栎属 } \\
\text { Trigonobalanus }\end{array}$ & T. doichangensis (Camus) Forman & 西藏聂荣县 Nierong, Tibet & & 14 & 7 & $2 \mathrm{x}$ & 1,475 & $\mathrm{~W}$ & TA & $\begin{array}{l}\text { 韩春艳和孙卫邦, } \\
2005\end{array}$ \\
\hline $\begin{array}{l}\text { 山毛榉科 } \\
\text { Fagaceae }\end{array}$ & $\begin{array}{l}\text { 三棱栋属 } \\
\text { Trigonobalanus }\end{array}$ & T. doichangensis (Camus) Forman & 西藏双湖 Shuanghu, Tibet & & 14 & 7 & $2 \mathrm{x}$ & 1,640 & $\mathrm{~W}$ & TA & $\begin{array}{l}\text { 韩春艳和孙卫邦, } \\
2005\end{array}$ \\
\hline
\end{tabular}


王家坚, 彭智邦, 孙航, 聂泽龙, 孟盈. 青藏高原与横断山被子植物区系演化的细胞地理学特征. 生物多样性, 2017, 25 (2): 218-225.

http://www.biodiversity-science.net/CN/10.17520/biods.2016281

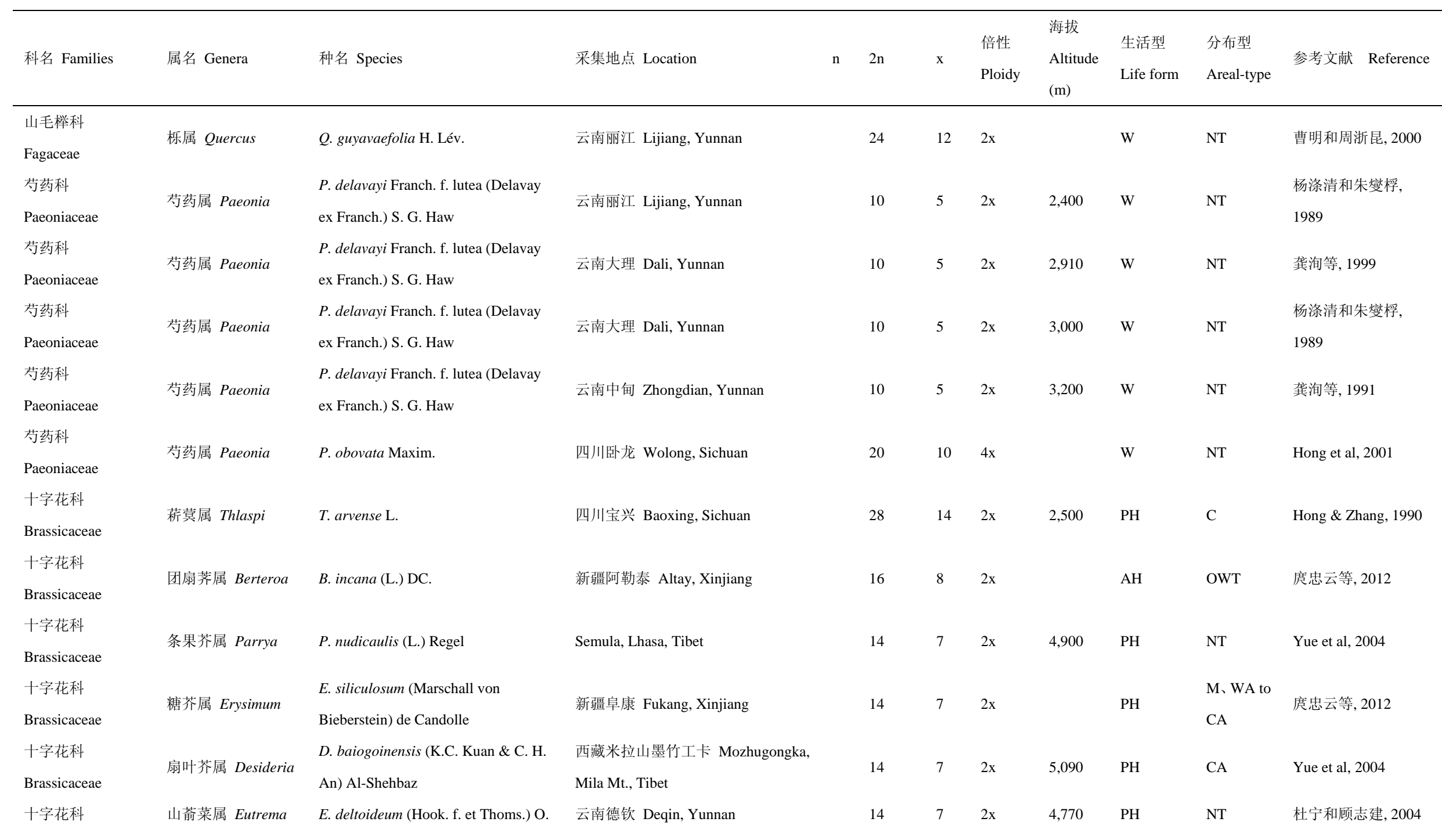


王家坚, 彭智邦, 孙航, 聂泽龙, 孟盈. 青藏高原与横断山被子植物区系演化的细胞地理学特征. 生物多样性, 2017, 25 (2): 218-225.

http://www.biodiversity-science.net/CN/10.17520/biods.2016281

\begin{tabular}{|c|c|c|c|c|c|c|c|c|c|c|c|}
\hline 科名 Families & 属名 Genera & 种名 Species & 采集地点 Location & $\mathrm{n}$ & $2 \mathrm{n}$ & $\mathrm{x}$ & $\begin{array}{l}\text { 倍性 } \\
\text { Ploidy }\end{array}$ & $\begin{array}{l}\text { 海拔 } \\
\text { Altitude } \\
\text { (m) }\end{array}$ & $\begin{array}{l}\text { 生活型 } \\
\text { Life form }\end{array}$ & $\begin{array}{l}\text { 分布型 } \\
\text { Areal-type }\end{array}$ & 参考文献 Reference \\
\hline Brassicaceae & & E. Schulz & & & & & & & & & \\
\hline $\begin{array}{l}\text { 十字花科 } \\
\text { Brassicaceae }\end{array}$ & 山萮菜属 Eutrema & E. wasabi (Siebold) Maxim. & 云南大理 Dali, Yunnan & & 28 & 7 & $4 \mathrm{x}$ & 3,000 & PH & NT & 杜宁和顾志建, 2004 \\
\hline $\begin{array}{l}\text { 十字花科 } \\
\text { Brassicaceae }\end{array}$ & $\begin{array}{l}\text { 芹叶萃属 } \\
\text { Smelowskia }\end{array}$ & S. calycina (Steph) C. A. Mey & $\begin{array}{l}\text { 新疆塔什库尔干 Taxkorgan, } \\
\text { Xinjiang }\end{array}$ & & 12 & 6 & $2 \mathrm{x}$ & & $\mathrm{PH}$ & $\mathrm{CA}$ & 度忠云等, 2012 \\
\hline $\begin{array}{l}\text { 十字花科 } \\
\text { Brassicaceae }\end{array}$ & $\begin{array}{l}\text { 假蒜芥属 } \\
\text { Sisymbriopsis }\end{array}$ & $\begin{array}{l}\text { S. mollipila (Maximowicz) } \\
\text { Botsschantzev }\end{array}$ & $\begin{array}{l}\text { 新疆塔什库尔干 Taxkorgan, } \\
\text { Xinjiang }\end{array}$ & & 14 & 7 & $2 \mathrm{x}$ & & АH & $\mathrm{CA}$ & 度忠云等, 2012 \\
\hline $\begin{array}{l}\text { 十字花科 } \\
\text { Brassicaceae }\end{array}$ & $\begin{array}{l}\text { 华羽芥属 } \\
\text { Sophiopsis }\end{array}$ & S. аппиа (Rupr.) O. E. Schlz & $\begin{array}{l}\text { 新疆塔什库尔干 Taxkorgan, } \\
\text { Xinjiang }\end{array}$ & & 12 & 6 & $2 \mathrm{x}$ & & PH & $\mathrm{CA}$ & 度忠云等, 2012 \\
\hline $\begin{array}{l}\text { 十字花科 } \\
\text { Brassicaceae }\end{array}$ & $\begin{array}{l}\text { 对枝菜属 } \\
\text { Cithareloma }\end{array}$ & C. vernum Bunge & 新疆阜康 Fukang, Xinjiang & & 12 & 6 & $2 \mathrm{x}$ & & $\mathrm{AH}$ & $\mathrm{CA}$ & 度忠云等, 2012 \\
\hline $\begin{array}{l}\text { 十字花科 } \\
\text { Brassicaceae }\end{array}$ & $\begin{array}{l}\text { 从䓳属 } \\
\text { Solms-laubachia }\end{array}$ & S. eurycarpa (Maxim.) Botsch. & Basho, Yela Mt., Tibet & & 14 & 7 & $2 \mathrm{x}$ & 4,710 & PH & EA & Yue et al, 2004 \\
\hline $\begin{array}{l}\text { 十字花科 } \\
\text { Brassicaceae }\end{array}$ & $\begin{array}{l}\text { 从菔属 } \\
\text { Solms-laubachia }\end{array}$ & S. eurycarpa (Maxim.) Botsch. & 云南德钦 Deqin, Yunnan & & 14 & 7 & $2 \mathrm{x}$ & 4,650 & PH & EA & Yue et al, 2003 \\
\hline $\begin{array}{l}\text { 十字花科 } \\
\text { Brassicaceae }\end{array}$ & $\begin{array}{l}\text { 从菔属 } \\
\text { Solms-laubachia }\end{array}$ & S. eurycarpa (Maxim.) Botsch. & $\begin{array}{l}\text { 四川亚丁稻城 Daocheng, Yading, } \\
\text { Sichuan }\end{array}$ & & 14 & 7 & $2 \mathrm{x}$ & 4,510 & PH & EA & Yue et al, 2004 \\
\hline
\end{tabular}


王家坚, 彭智邦, 孙航, 聂泽龙, 孟盈. 青藏高原与横断山被子植物区系演化的细胞地理学特征. 生物多样性, 2017, 25 (2): 218-225.

http://www.biodiversity-science.net/CN/10.17520/biods.2016281

\begin{tabular}{|c|c|c|c|c|c|c|c|c|c|c|c|}
\hline 科名 Families & 属名 Genera & 种名 Species & 采集地点 Location & $\mathrm{n}$ & $2 n$ & $\mathrm{x}$ & $\begin{array}{l}\text { 倍性 } \\
\text { Ploidy }\end{array}$ & $\begin{array}{l}\text { 海拔 } \\
\text { Altitude } \\
\text { (m) }\end{array}$ & $\begin{array}{l}\text { 生活型 } \\
\text { Life form }\end{array}$ & $\begin{array}{l}\text { 分布型 } \\
\text { Areal-type }\end{array}$ & 参考文献 Reference \\
\hline $\begin{array}{l}\text { 十字花科 } \\
\text { Brassicaceae }\end{array}$ & $\begin{array}{l}\text { 从菔属 } \\
\text { Solms-laubachia }\end{array}$ & S. lanata Botsch. & Resela, Lhasa, Tibet & & 14 & 7 & $2 \mathrm{x}$ & 4,800 & PH & EA & Yue et al, 2004 \\
\hline $\begin{array}{l}\text { 十字花科 } \\
\text { Brassicaceae }\end{array}$ & $\begin{array}{l}\text { 丛菔属 } \\
\text { Solms-laubachia }\end{array}$ & S. lanata Botsch. & Semula, Lhasa, Tibet & & 14 & 7 & $2 \mathrm{x}$ & 5,100 & PH & EA & Yue et al, 2004 \\
\hline $\begin{array}{l}\text { 十字花科 } \\
\text { Brassicaceae }\end{array}$ & $\begin{array}{l}\text { 从菔属 } \\
\text { Solms-laubachia }\end{array}$ & $\begin{array}{l}\text { S. linearifolia (W. W. Sm.) O. E. } \\
\text { Schulz }\end{array}$ & 云南德钦 Deqin, Yunnan & & 14 & 7 & $2 \mathrm{x}$ & 4,600 & PH & EA & Yue et al, 2003 \\
\hline $\begin{array}{l}\text { 十字花科 } \\
\text { Brassicaceae }\end{array}$ & $\begin{array}{l}\text { 从菔属 } \\
\text { Solms-laubachia }\end{array}$ & S. minor Hand. -Mazz. & 云南中甸 Zhongdian, Yunnan & & 14 & 7 & $2 \mathrm{x}$ & 4,330 & PH & EA & Yue et al, 2003 \\
\hline $\begin{array}{l}\text { 十字花科 } \\
\text { Brassicaceae }\end{array}$ & $\begin{array}{l}\text { 从菔属 } \\
\text { Solms-laubachia }\end{array}$ & $\begin{array}{l}\text { S. platycarpa (Hook. f. \& Thomson) } \\
\text { Botsch. }\end{array}$ & 西藏当雄 Dangxiong, Tibet & & 14 & 7 & $2 \mathrm{x}$ & 5,180 & PH & EA & Yue et al, 2004 \\
\hline $\begin{array}{l}\text { 十字花科 } \\
\text { Brassicaceae }\end{array}$ & $\begin{array}{l}\text { 从菔属 } \\
\text { Solms-laubachia }\end{array}$ & S. pulcherrima Muschl. ex Diels & 云南丽江 Lijiang, Yunnan & & 14 & 7 & $2 \mathrm{x}$ & 4,210 & PH & EA & Yue et al, 2003 \\
\hline $\begin{array}{l}\text { 十字花科 } \\
\text { Brassicaceae }\end{array}$ & $\begin{array}{l}\text { 从菔属 } \\
\text { Solms-laubachia }\end{array}$ & S. pulcherrima Muschl. ex Diels & $\begin{array}{l}\text { 云南丽江 Gangheba, Lijiang, } \\
\text { Yunnan }\end{array}$ & & 14 & 7 & $2 \mathrm{x}$ & 3,670 & $\mathrm{PH}$ & EA & Yue et al, 2004 \\
\hline $\begin{array}{l}\text { 十字花科 } \\
\text { Brassicaceae }\end{array}$ & $\begin{array}{l}\text { 从菔属 } \\
\text { Solms-laubachia }\end{array}$ & S. retropilosa Botsch. & 四川芕城 Xiancheng, Sichuan & & 28 & 7 & $4 \mathrm{x}$ & 4,790 & PH & EA & Yue et al, 2003 \\
\hline $\begin{array}{l}\text { 十字花科 } \\
\text { Brassicaceae }\end{array}$ & $\begin{array}{l}\text { 从菔属 } \\
\text { Solms-laubachia }\end{array}$ & S. retropilosa Botsch. & $\begin{array}{l}\text { 四川康定折多山 Zheduo Mt., } \\
\text { Kangding, Sichuan }\end{array}$ & & 14 & 7 & $2 \mathrm{x}$ & 4,060 & PH & EA & Yue et al, 2004 \\
\hline $\begin{array}{l}\text { 十字花科 } \\
\text { Brassicaceae }\end{array}$ & $\begin{array}{l}\text { 从菔属 } \\
\text { Solms-laubachia }\end{array}$ & S. retropilosa Botsch. & $\begin{array}{l}\text { 西藏左贡东大山 Dongda Mt., } \\
\text { Zuogong, Tibet }\end{array}$ & & 14 & 7 & $2 \mathrm{x}$ & 5,090 & PH & EA & Yue et al, 2004 \\
\hline $\begin{array}{l}\text { 十字花科 } \\
\text { Brassicaceae }\end{array}$ & $\begin{array}{l}\text { 丛菔属 } \\
\text { Solms-laubachia }\end{array}$ & $\begin{array}{l}\text { S. xerophyta (W. W. Sm.) H. F. } \\
\text { Comber }\end{array}$ & 四川稻城 Daocheng, Sichuan & & 14 & 7 & $2 \mathrm{x}$ & 4,530 & PH & EA & Yue et al, 2004 \\
\hline 十字花科 & 从菔属 & S. xerophyta (W. W. Sm.) H. F. & 四川中甸大雪山 Snow Mt., & & 14 & 7 & $2 \mathrm{x}$ & 4,340 & PH & EA & Yue et al, 2004 \\
\hline
\end{tabular}


王家坚, 彭智邦, 孙航, 聂泽龙, 孟盈. 青藏高原与横断山被子植物区系演化的细胞地理学特征. 生物多样性, 2017, 25 (2): 218-225.

http://www.biodiversity-science.net/CN/10.17520/biods.2016281

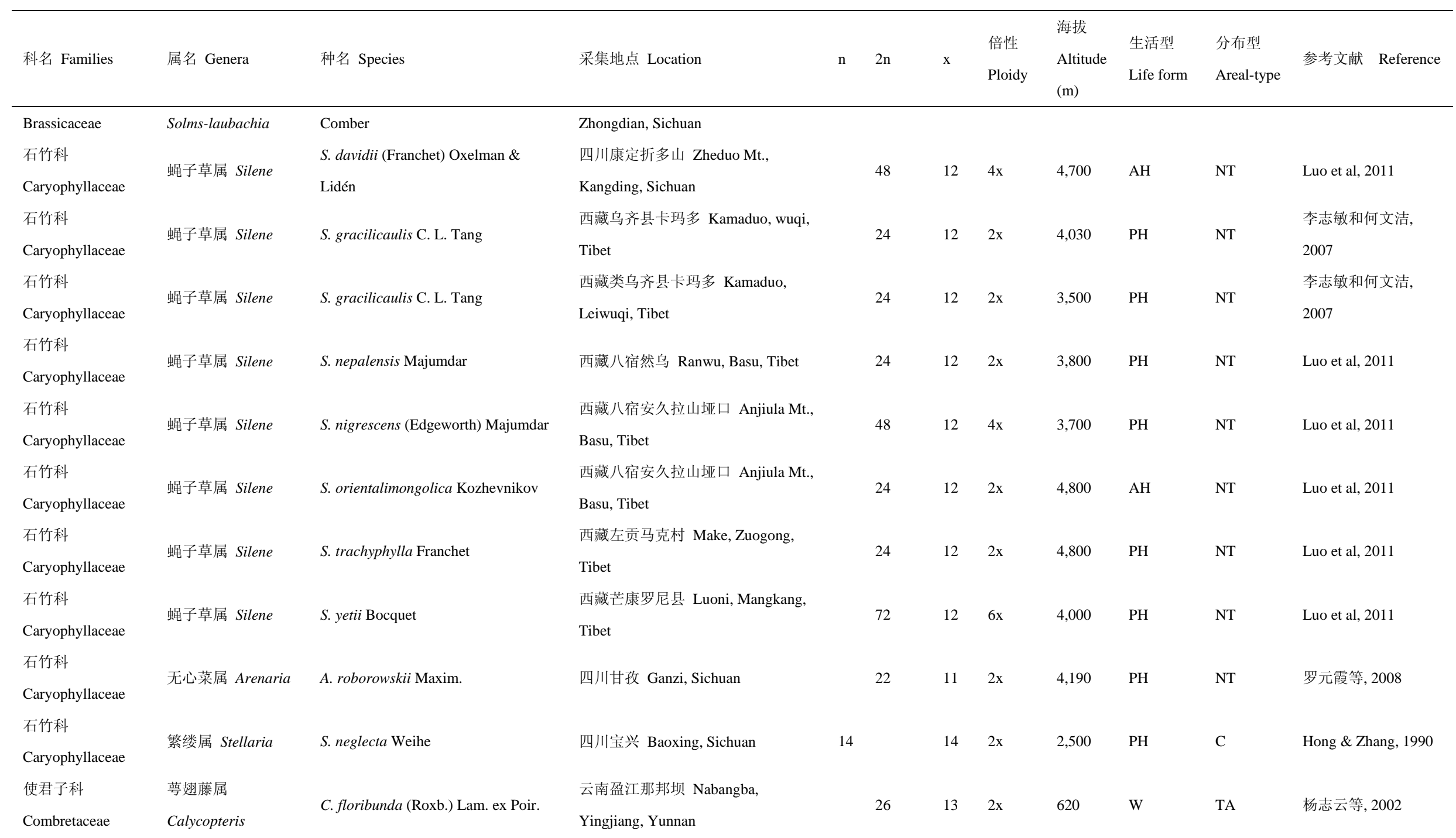


王家坚, 彭智邦, 孙航, 聂泽龙, 孟盈. 青藏高原与横断山被子植物区系演化的细胞地理学特征. 生物多样性, 2017, 25 (2): 218-225.

http://www.biodiversity-science.net/CN/10.17520/biods.2016281

\begin{tabular}{|c|c|c|c|c|c|c|c|c|c|c|c|}
\hline 科名 Families & 属名 Genera & 种名 Species & 采集地点 Location & $\mathrm{n}$ & $2 \mathrm{n}$ & $\mathrm{x}$ & $\begin{array}{l}\text { 倍性 } \\
\text { Ploidy }\end{array}$ & $\begin{array}{l}\text { 海拔 } \\
\text { Altitude } \\
\text { (m) }\end{array}$ & $\begin{array}{l}\text { 生活型 } \\
\text { Life form }\end{array}$ & $\begin{array}{l}\text { 分布型 } \\
\text { Areal-type }\end{array}$ & 参考文献 Reference \\
\hline $\begin{array}{l}\text { 薯渵科 } \\
\text { Dioscoreaceae }\end{array}$ & 薯顽属 Dioscorea & D. althaeoides Knuth & 云南维西 Weixi, Yunnan & & 20 & 10 & $2 \mathrm{x}$ & & $\mathrm{PH}$ & $\mathrm{P}$ & $\begin{array}{l}\text { 江苏省植物研究所薯 } \\
\text { 蓣课题研究组, } 1976\end{array}$ \\
\hline $\begin{array}{l}\text { 薯濒科 } \\
\text { Dioscoreaceae }\end{array}$ & 薯䓔属 Dioscorea & D. collettii Hook. f. & 四川峨眉山 Emei Mt., Sichuan & & 20 & 10 & $2 \mathrm{x}$ & & $\mathrm{PH}$ & $\mathrm{P}$ & $\begin{array}{l}\text { 江苏省植物研究所薯 } \\
\text { 䓔课题研究组, } 1976\end{array}$ \\
\hline $\begin{array}{l}\text { 薯濒科 } \\
\text { Dioscoreaceae }\end{array}$ & 薯萝属 Dioscorea & D. opposita Thunb. & 四川峨眉山 Emei Mt., Sichuan & & 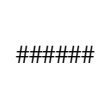 & 10 & $14 \mathrm{x}$ & & $\mathrm{PH}$ & $\mathrm{P}$ & 秦慧贞等, 1985 \\
\hline $\begin{array}{l}\text { 薯濒科 } \\
\text { Dioscoreaceae }\end{array}$ & 薯顽属 Dioscorea & D. panthaica Prain \& Burkill & 云南丽江 Lijiang, Yunnan & & 40 & 10 & $4 \mathrm{x}$ & & $\mathrm{PH}$ & $\mathrm{P}$ & $\begin{array}{l}\text { 江苏省植物研究所薯 } \\
\text { 漖课题研究组, } 1976\end{array}$ \\
\hline $\begin{array}{l}\text { 薯濒科 } \\
\text { Dioscoreaceae }\end{array}$ & 薯赚属 Dioscorea & D. parviflora C. T. Ting & 云南永胜 Yongsheng, Yunnan & & 20 & 10 & $2 \mathrm{x}$ & & $\mathrm{PH}$ & $\mathrm{P}$ & 裴鉴等, 1979 \\
\hline $\begin{array}{l}\text { 天门冬科 } \\
\text { Asparagaceae }\end{array}$ & $\begin{array}{l}\text { 舞鹤草属 } \\
\text { Maianthemum }\end{array}$ & $\begin{array}{l}\text { M. atropurpureum (Franchet) La } \\
\text { Frankie }\end{array}$ & 四川峨眉山 Emei Mt., Sichuan & & 36 & 18 & $2 \mathrm{x}$ & 2,300 & PH & NT & 唐自慧等, 2009 \\
\hline $\begin{array}{l}\text { 天门冬科 } \\
\text { Asparagaceae }\end{array}$ & $\begin{array}{l}\text { 舞鹤草属 } \\
\text { Maianthemum }\end{array}$ & $\begin{array}{l}\text { M. atropurpureum (Franchet) La } \\
\text { Frankie }\end{array}$ & 重庆金佛山 Jinfo Mt., Chongqing & & 36 & 18 & $2 \mathrm{x}$ & 2,000 & PH & NT & 唐自慧等, 2009 \\
\hline $\begin{array}{l}\text { 天门冬科 } \\
\text { Asparagaceae }\end{array}$ & $\begin{array}{l}\text { 舞鹤草属 } \\
\text { Maianthemum }\end{array}$ & $\begin{array}{l}\text { M. atropurpureum (Franchet) La } \\
\text { Frankie }\end{array}$ & 四川峨眉 Emei, Sichuan & & 36 & 18 & $2 \mathrm{x}$ & 2,300 & $\mathrm{PH}$ & NT & 唐自慧等, 2009 \\
\hline 天门冬科 & 舞鹤草属 & M. atropurpureum (Franch.) Wang \& & 云南贡山 Gongshan, Yunnan & & 32 & 16 & $2 \mathrm{x}$ & 2,600 & $\mathrm{PH}$ & NT & 王丽等, 1993 \\
\hline
\end{tabular}


王家坚, 彭智邦, 孙航, 聂泽龙, 孟盈. 青藏高原与横断山被子植物区系演化的细胞地理学特征. 生物多样性, 2017, 25 (2): 218-225.

http://www.biodiversity-science.net/CN/10.17520/biods.2016281

\begin{tabular}{|c|c|c|c|c|c|c|c|c|c|c|c|}
\hline 科名 Families & 属名 Genera & 种名 Species & 采集地点 Location & $\mathrm{n}$ & $2 \mathrm{n}$ & $\mathrm{x}$ & $\begin{array}{l}\text { 倍性 } \\
\text { Ploidy }\end{array}$ & $\begin{array}{l}\text { 海拔 } \\
\text { Altitude } \\
\text { (m) }\end{array}$ & $\begin{array}{l}\text { 生活型 } \\
\text { Life form }\end{array}$ & $\begin{array}{l}\text { 分布型 } \\
\text { Areal-type }\end{array}$ & 参考文献 Reference \\
\hline Asparagaceae & Maianthemum & Tang & & & & & & & & & \\
\hline $\begin{array}{l}\text { 天门冬科 } \\
\text { Asparagaceae }\end{array}$ & $\begin{array}{l}\text { 舞鹤草属 } \\
\text { Maianthemum }\end{array}$ & M. forrestii (W. W. Smith) La Frankie & 西藏芒康 Mangkang, Tibet & & 28 & 14 & $2 \mathrm{x}$ & 4,494 & PH & NT & Meng et al, 2010 \\
\hline $\begin{array}{l}\text { 天门冬科 } \\
\text { Asparagaceae }\end{array}$ & $\begin{array}{l}\text { 舞鹤草属 } \\
\text { Maianthemum }\end{array}$ & M. fusca Wall. & 云南云龙 Yunlong, Yunnan & & 30 & 15 & $2 \mathrm{x}$ & 2,900 & PH & NT & 王丽等, 1994 \\
\hline $\begin{array}{l}\text { 天门冬科 } \\
\text { Asparagaceae }\end{array}$ & $\begin{array}{l}\text { 舞鹤草属 } \\
\text { Maianthemum }\end{array}$ & M. fusca Wall. & 西藏墨脱 Motuo, Tibet & & 36 & 18 & $4 \mathrm{x}$ & 1,900 & PH & NT & $\begin{array}{l}\text { 顾志建和孙先风, } \\
1998\end{array}$ \\
\hline $\begin{array}{l}\text { 天门冬科 } \\
\text { Asparagaceae }\end{array}$ & $\begin{array}{l}\text { 舞鹤草属 } \\
\text { Maianthemum }\end{array}$ & M. henryi (Baker) La Frankie & 云南大理 Dali, Yunnan & & 36 & 18 & $2 \mathrm{x}$ & 2,930 & PH & NT & 唐自慧等, 2009 \\
\hline $\begin{array}{l}\text { 天门冬科 } \\
\text { Asparagaceae }\end{array}$ & $\begin{array}{l}\text { 舞鹤草属 } \\
\text { Maianthemum }\end{array}$ & M. henryi (Baker) La Frankie & 四川康定 Kangding, Sichuan & & 36 & 18 & $2 \mathrm{x}$ & 2,880 & PH & NT & 唐自慧等, 2009 \\
\hline $\begin{array}{l}\text { 天门冬科 } \\
\text { Asparagaceae }\end{array}$ & $\begin{array}{l}\text { 舞鹤草属 } \\
\text { Maianthemum }\end{array}$ & M. henryi (Baker) La Frankie & 四川卧龙 Wolong, Sichuan & & 36 & 18 & $2 \mathrm{x}$ & 3,400 & PH & NT & 唐自慧等, 2009 \\
\hline $\begin{array}{l}\text { 天门冬科 } \\
\text { Asparagaceae }\end{array}$ & $\begin{array}{l}\text { 舞鹤草属 } \\
\text { Maianthemum }\end{array}$ & M. henryi (Baker) Hara & 云南大理 Dali, Yunnan & & 78 & 13 & $6 \mathrm{x}$ & 3,000 & PH & NT & 王丽等, 1995 \\
\hline $\begin{array}{l}\text { 天门冬科 } \\
\text { Asparagaceae }\end{array}$ & $\begin{array}{l}\text { 舞鹤草属 } \\
\text { Maianthemum }\end{array}$ & $\begin{array}{l}\text { M. lichiangense (W. W. Sm.) W. W. } \\
\text { Sm. }\end{array}$ & Zuogong, Tibet & & 56 & 14 & $4 \mathrm{x}$ & 3,710 & PH & NT & Meng et al, 2010 \\
\hline
\end{tabular}


王家坚, 彭智邦, 孙航, 聂泽龙, 孟盈. 青藏高原与横断山被子植物区系演化的细胞地理学特征. 生物多样性, 2017, 25 (2): 218-225.

http://www.biodiversity-science.net/CN/10.17520/biods.2016281

\begin{tabular}{|c|c|c|c|c|c|c|c|c|c|c|c|}
\hline 科名 Families & 属名 Genera & 种名 Species & 采集地点 Location & $\mathrm{n}$ & $2 \mathrm{n}$ & $\mathrm{x}$ & $\begin{array}{l}\text { 倍性 } \\
\text { Ploidy }\end{array}$ & $\begin{array}{l}\text { 海拔 } \\
\text { Altitude } \\
\text { (m) }\end{array}$ & $\begin{array}{l}\text { 生活型 } \\
\text { Life form }\end{array}$ & $\begin{array}{l}\text { 分布型 } \\
\text { Areal-type }\end{array}$ & 参考文献 Reference \\
\hline $\begin{array}{l}\text { 天门冬科 } \\
\text { Asparagaceae }\end{array}$ & $\begin{array}{l}\text { 舞鹤草属 } \\
\text { Maianthemum }\end{array}$ & M. nanchuanense H. Li \& J. L. Huang & 重庆金佛山 Jinfo Mt., Chongqing & & 36 & 18 & $2 \mathrm{x}$ & 1,800 & $\mathrm{PH}$ & NT & 唐自慧等, 2009 \\
\hline $\begin{array}{l}\text { 天门冬科 } \\
\text { Asparagaceae }\end{array}$ & $\begin{array}{l}\text { 舞鹤草属 } \\
\text { Maianthemum }\end{array}$ & M. purpurea (Wallich) La Frankie & Mangkang, Tibet & & 56 & 14 & $4 \mathrm{x}$ & 3,699 & $\mathrm{PH}$ & NT & Meng et al, 2010 \\
\hline $\begin{array}{l}\text { 天门冬科 } \\
\text { Asparagaceae }\end{array}$ & $\begin{array}{l}\text { 舞鹤草属 } \\
\text { Maianthemum }\end{array}$ & $\begin{array}{l}\text { M. szechuanicum (F. T. Wang \& } \\
\text { Tang) H. Li }\end{array}$ & 四川峨眉山 Emei Mt., Sichuan & & 36 & 18 & $2 \mathrm{x}$ & 2,430 & $\mathrm{PH}$ & NT & 唐自慧等, 2009 \\
\hline $\begin{array}{l}\text { 天门冬科 } \\
\text { Asparagaceae }\end{array}$ & $\begin{array}{l}\text { 舞鹤草属 } \\
\text { Maianthemum }\end{array}$ & M. tatsienensis (Franchet) La Frankie & 四川达州 Dazhou, Sichuan & & 36 & 18 & $2 \mathrm{x}$ & 1,850 & $\mathrm{PH}$ & NT & 唐自慧等, 2009 \\
\hline $\begin{array}{l}\text { 天门冬科 } \\
\text { Asparagaceae }\end{array}$ & $\begin{array}{l}\text { 舞鹤草属 } \\
\text { Maianthemum }\end{array}$ & M. tatsienensis (Franchet) La Frankie & 四川峨眉山 Emei Mt., Sichuan & & 36 & 18 & $2 \mathrm{x}$ & 1,740 & $\mathrm{PH}$ & NT & 唐自慧等, 2009 \\
\hline $\begin{array}{l}\text { 天门冬科 } \\
\text { Asparagaceae }\end{array}$ & $\begin{array}{l}\text { 舞鹤草属 } \\
\text { Maianthemum }\end{array}$ & M. tatsienensis (Franchet) La Frankie & 四川峨眉山 Emei Mt., Sichuan & & 36 & 18 & $2 \mathrm{x}$ & 2,430 & $\mathrm{PH}$ & NT & 唐自慧等, 2009 \\
\hline $\begin{array}{l}\text { 天门冬科 } \\
\text { Asparagaceae }\end{array}$ & $\begin{array}{l}\text { 舞鹤草属 } \\
\text { Maianthemum }\end{array}$ & M. tatsienensis (Franchet) La Frankie & 四川峨眉山 Emei Mt., Sichuan & & 36 & 18 & $2 \mathrm{x}$ & 3,070 & $\mathrm{PH}$ & NT & 唐自慧等, 2009 \\
\hline $\begin{array}{l}\text { 天门冬科 } \\
\text { Asparagaceae }\end{array}$ & $\begin{array}{l}\text { 舞鹤草属 } \\
\text { Maianthemum }\end{array}$ & M. tatsienensis (Franchet) La Frankie & 云南丽江 Lijiang, Yunnan & & 72 & 18 & $4 \mathrm{x}$ & 2,800 & $\mathrm{PH}$ & NT & 唐自慧等, 2009 \\
\hline $\begin{array}{l}\text { 天门冬科 } \\
\text { Asparagaceae }\end{array}$ & $\begin{array}{l}\text { 舞鹤草属 } \\
\text { Maianthemum }\end{array}$ & M. tatsienensis (Franchet) La Frankie & 云南大理 Dali, Yunnan & & 36 & 18 & $2 \mathrm{x}$ & 2,930 & $\mathrm{PH}$ & NT & 唐自慧等, 2009 \\
\hline $\begin{array}{l}\text { 天门冬科 } \\
\text { Asparagaceae }\end{array}$ & $\begin{array}{l}\text { 舞鹤草属 } \\
\text { Maianthemum }\end{array}$ & M. tatsienensis (Franchet) La Frankie & 四川峨眉 Emei, Sichuan & & 36 & 18 & $2 \mathrm{x}$ & 3,070 & $\mathrm{PH}$ & NT & 唐自慧等, 2009 \\
\hline $\begin{array}{l}\text { 天门冬科 } \\
\text { Asparagaceae }\end{array}$ & $\begin{array}{l}\text { 舞鹤草属 } \\
\text { Maianthemum }\end{array}$ & M. tatsienensis (Franchet) La Frankie & 四川峨眉 Emei, Sichuan & & 36 & 18 & $2 \mathrm{x}$ & 2,430 & $\mathrm{PH}$ & NT & 唐自慧等, 2009 \\
\hline 天门冬科 & 舞鹤草属 & M. tatsienensis (Franchet) La Frankie & 四川峨眉 Emei, Sichuan & & 36 & 18 & $2 \mathrm{x}$ & 1,740 & $\mathrm{PH}$ & NT & 唐自慧等, 2009 \\
\hline
\end{tabular}


王家坚, 彭智邦, 孙航, 聂泽龙, 孟盈. 青藏高原与横断山被子植物区系演化的细胞地理学特征. 生物多样性, 2017, 25 (2): 218-225.

http://www.biodiversity-science.net/CN/10.17520/biods.2016281

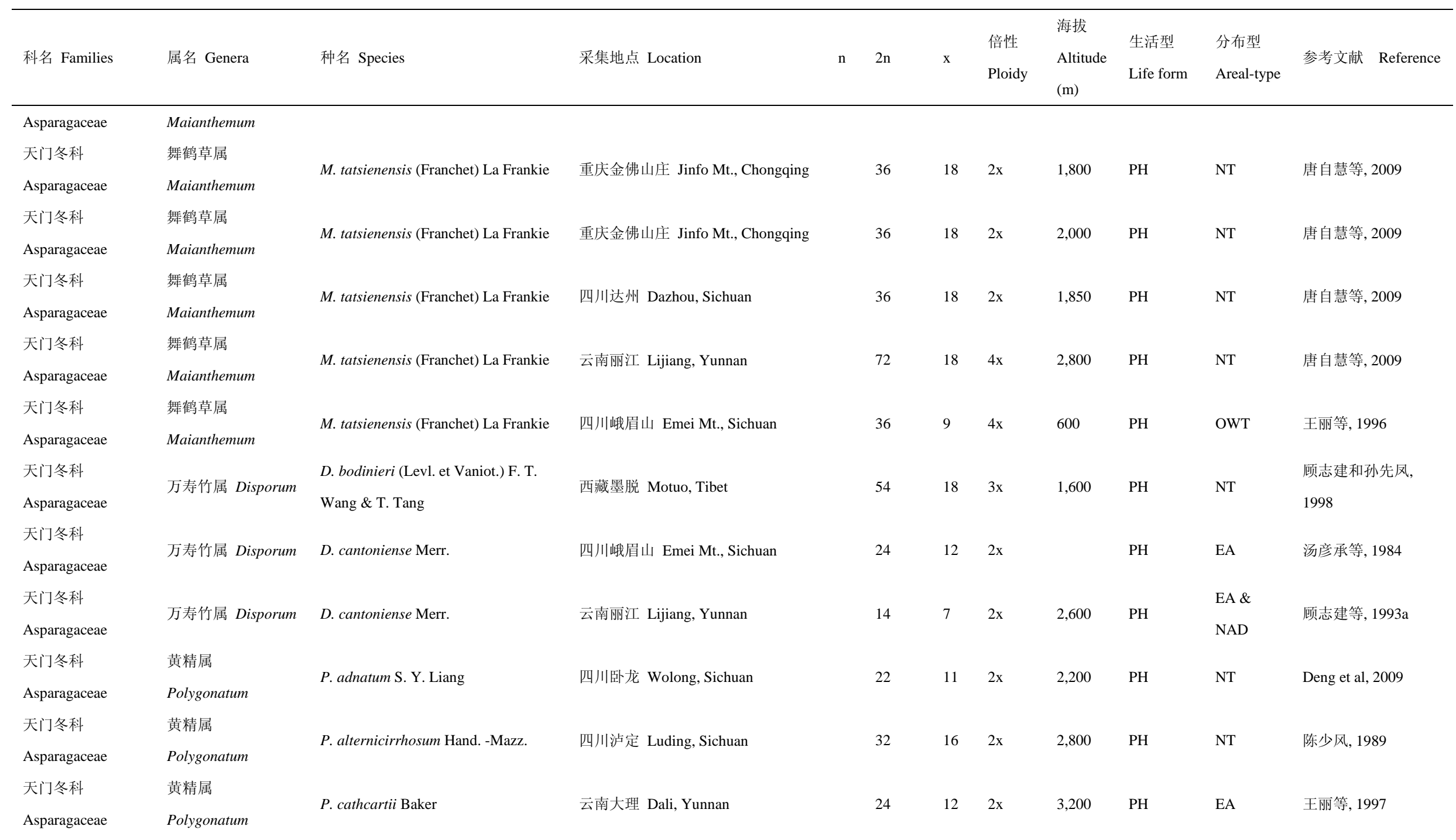


王家坚, 彭智邦, 孙航, 聂泽龙, 孟盈. 青藏高原与横断山被子植物区系演化的细胞地理学特征. 生物多样性, 2017, 25 (2): 218-225.

http://www.biodiversity-science.net/CN/10.17520/biods.2016281

\begin{tabular}{|c|c|c|c|c|c|c|c|c|c|c|c|}
\hline 科名 Families & 属名 Genera & 种名 Species & 采集地点 Location & $\mathrm{n}$ & $2 \mathrm{n}$ & $\mathrm{x}$ & $\begin{array}{l}\text { 倍性 } \\
\text { Ploidy }\end{array}$ & $\begin{array}{l}\text { 海拔 } \\
\text { Altitude } \\
\text { (m) }\end{array}$ & $\begin{array}{l}\text { 生活型 } \\
\text { Life form }\end{array}$ & $\begin{array}{l}\text { 分布型 } \\
\text { Areal-type }\end{array}$ & 参考文献 Reference \\
\hline $\begin{array}{l}\text { 天门冬科 } \\
\text { Asparagaceae }\end{array}$ & $\begin{array}{l}\text { 黄精属 } \\
\text { Polygonatum }\end{array}$ & P. cirrhifolium (Wall.) Royal & 西藏双湖 Shuanghu, Tibet & & 42 & 7 & $6 \mathrm{x}$ & 4,300 & $\mathrm{PH}$ & OWT & 顾志建等, 1993 \\
\hline $\begin{array}{l}\text { 天门冬科 } \\
\text { Asparagaceae }\end{array}$ & $\begin{array}{l}\text { 黄精属 } \\
\text { Polygonatum }\end{array}$ & P. cirrhifolium Royle & 西藏波密 Bomi, Tibet & & 52 & 13 & $4 \mathrm{x}$ & 3,000 & $\mathrm{PH}$ & NT & 顾志建等, 1993b \\
\hline $\begin{array}{l}\text { 天门冬科 } \\
\text { Asparagaceae }\end{array}$ & $\begin{array}{l}\text { 黄精属 } \\
\text { Polygonatum }\end{array}$ & P. cirrhifolium Royle & 云南云龙 Yunlong, Yunnan & & 24 & 12 & $2 \mathrm{x}$ & 3,100 & $\mathrm{PH}$ & EA & 王丽等, 1998 \\
\hline $\begin{array}{l}\text { 天门冬科 } \\
\text { Asparagaceae }\end{array}$ & $\begin{array}{l}\text { 黄精属 } \\
\text { Polygonatum }\end{array}$ & P. curvistylum Hua & 云南大理 Dali, Yunnan & & 24 & 12 & $2 \mathrm{x}$ & 3,200 & $\mathrm{PH}$ & CA & 王丽等, 1999 \\
\hline $\begin{array}{l}\text { 天门冬科 } \\
\text { Asparagaceae }\end{array}$ & $\begin{array}{l}\text { 黄精属 } \\
\text { Polygonatum }\end{array}$ & P. curvistylum Huu. & 四川金佛山林下 Jinfo Mt., Sichuan & & 28 & 14 & $2 \mathrm{x}$ & 1,900 & $\mathrm{PH}$ & NT & 杨继等, 1988 \\
\hline $\begin{array}{l}\text { 天门冬科 } \\
\text { Asparagaceae }\end{array}$ & $\begin{array}{l}\text { 黄精属 } \\
\text { Polygonatum }\end{array}$ & P. hirtellum Hand. -Mazz. & 四川康定 Kangding, Sichuan & & 28 & 14 & $2 \mathrm{x}$ & 2,880 & PH & NT & Deng et al, 2009 \\
\hline $\begin{array}{l}\text { 天门冬科 } \\
\text { Asparagaceae }\end{array}$ & $\begin{array}{l}\text { 黄精属 } \\
\text { Polygonatum }\end{array}$ & P. kingianum Coll. et Hemal. & $\begin{array}{l}\text { 四川金佛山河滩沙地 Jinfo Mt., } \\
\text { Sichuan }\end{array}$ & & 26 & 13 & $2 \mathrm{x}$ & 800 & $\mathrm{PH}$ & NT & 杨继等, 1988 \\
\hline $\begin{array}{l}\text { 天门冬科 } \\
\text { Asparagaceae }\end{array}$ & $\begin{array}{l}\text { 黄精属 } \\
\text { Polygonatum }\end{array}$ & P. kingianum Collett \& Hemsl. & 四川峨眉山 Emei Mt., Sichuan & & 26 & 13 & $2 \mathrm{x}$ & 900 & $\mathrm{PH}$ & NT & Deng et al, 2009 \\
\hline 天门冬科 & 黄精属 & P. megaphyllum & 甘肃黄土高原子午岭林区 Z Ziwu Mt., & & 20 & 10 & $2 \mathrm{x}$ & 1,400 & $\mathrm{PH}$ & NT & 范小峰等, 2000 \\
\hline
\end{tabular}


王家坚, 彭智邦, 孙航, 聂泽龙, 孟盈. 青藏高原与横断山被子植物区系演化的细胞地理学特征. 生物多样性, 2017, 25 (2): 218-225.

http://www.biodiversity-science.net/CN/10.17520/biods.2016281

\begin{tabular}{|c|c|c|c|c|c|c|c|c|c|c|c|}
\hline 科名 Families & 属名 Genera & 种名 Species & 采集地点 Location & $\mathrm{n}$ & $2 \mathrm{n}$ & $\mathrm{x}$ & $\begin{array}{l}\text { 倍性 } \\
\text { Ploidy }\end{array}$ & $\begin{array}{l}\text { 海拔 } \\
\text { Altitude } \\
\text { (m) }\end{array}$ & $\begin{array}{l}\text { 生活型 } \\
\text { Life form }\end{array}$ & $\begin{array}{l}\text { 分布型 } \\
\text { Areal-type }\end{array}$ & 参考文献 Reference \\
\hline Asparagaceae & Polygonatum & & Gansu & & & & & & & & \\
\hline $\begin{array}{l}\text { 天门冬科 } \\
\text { Asparagaceae }\end{array}$ & $\begin{array}{l}\text { 黄精属 } \\
\text { Polygonatum }\end{array}$ & P. odoratum Druce & 四川峨眉山 Emei Mt., Sichuan & & 22 & 11 & $2 \mathrm{x}$ & 800 & $\mathrm{PH}$ & NT & 方永峑䧼, 1989 \\
\hline $\begin{array}{l}\text { 天门冬科 } \\
\text { Asparagaceae }\end{array}$ & $\begin{array}{l}\text { 黄精属 } \\
\text { Polygonatum }\end{array}$ & P. oppisitifolium Royle. & 西藏墨脱 Motuo, Tibet & & 22 & 11 & $2 \mathrm{x}$ & 900 & $\mathrm{w}$ & CA & $\begin{array}{l}\text { 顾志建和孙先风, } \\
1998\end{array}$ \\
\hline $\begin{array}{l}\text { 天门冬科 } \\
\text { Asparagaceae }\end{array}$ & $\begin{array}{l}\text { 黄精属 } \\
\text { Polygonatum }\end{array}$ & P. prattii Baker & 云南大理 Dali, Yunnan & & 28 & 14 & $2 \mathrm{x}$ & & $\mathrm{PH}$ & NT & 杨继等, 1992 \\
\hline $\begin{array}{l}\text { 天门冬科 } \\
\text { Asparagaceae }\end{array}$ & $\begin{array}{l}\text { 黄精属 } \\
\text { Polygonatum }\end{array}$ & P. sibiricum Delar. & 四川卧龙 Wolong, Sichuan & & 30 & 15 & $2 \mathrm{x}$ & 1,900 & $\mathrm{PH}$ & NT & Deng et al, 2009 \\
\hline $\begin{array}{l}\text { 天门冬科 } \\
\text { Asparagaceae }\end{array}$ & $\begin{array}{l}\text { 黄精属 } \\
\text { Polygonatum }\end{array}$ & P. tessellatum Wang \& Tang & 云南大理 Dali, Yunnan & & 30 & 15 & $2 \mathrm{x}$ & 2,620 & PH & NT & Deng et al, 2009 \\
\hline $\begin{array}{l}\text { 天门冬科 } \\
\text { Asparagaceae }\end{array}$ & $\begin{array}{l}\text { 黄精属 } \\
\text { Polygonatum }\end{array}$ & P. verticillatum All. & 四川卧龙 Wolong, Sichuan & & 30 & 15 & $2 \mathrm{x}$ & 2,050 & $\mathrm{PH}$ & NT & Deng et al, 2009 \\
\hline $\begin{array}{l}\text { 天门冬科 } \\
\text { Asparagaceae }\end{array}$ & $\begin{array}{l}\text { 黄精属 } \\
\text { Polygonatum }\end{array}$ & P. zanlansciamense Pamp. & $\begin{array}{l}\text { 四川金佛山林下阴湿处和路边草从 } \\
\text { 中 Jinfo Mt., Sichuan }\end{array}$ & & 28 & 14 & $2 \mathrm{x}$ & 1,800 & $\mathrm{PH}$ & NT & 杨继等, 1988 \\
\hline $\begin{array}{l}\text { 天门冬科 } \\
\text { Asparagaceae }\end{array}$ & $\begin{array}{l}\text { 黄精属 } \\
\text { Polygonatum }\end{array}$ & P. zanlansciamense Pamp. & $\begin{array}{l}\text { 四川金佛山林下阴湿处和路边草从 } \\
\text { 中 Jinfo Mt., Sichuan }\end{array}$ & & 30 & 15 & $2 \mathrm{x}$ & 1,800 & PH & NT & 杨继等, 1988 \\
\hline
\end{tabular}


王家坚, 彭智邦, 孙航, 聂泽龙, 孟盈. 青藏高原与横断山被子植物区系演化的细胞地理学特征. 生物多样性, 2017, 25 (2): 218-225.

http://www.biodiversity-science.net/CN/10.17520/biods.2016281

\begin{tabular}{|c|c|c|c|c|c|c|c|c|c|c|c|}
\hline 科名 Families & 属名 Genera & 种名 Species & 采集地点 Location & $\mathrm{n}$ & $2 n$ & $\mathrm{x}$ & $\begin{array}{l}\text { 倍性 } \\
\text { Ploidy }\end{array}$ & $\begin{array}{l}\text { 海拔 } \\
\text { Altitude } \\
\text { (m) }\end{array}$ & $\begin{array}{l}\text { 生活型 } \\
\text { Life form }\end{array}$ & $\begin{array}{l}\text { 分布型 } \\
\text { Areal-type }\end{array}$ & 参考文献 Reference \\
\hline $\begin{array}{l}\text { 天门冬科 } \\
\text { Asparagaceae }\end{array}$ & $\begin{array}{l}\text { 黄精属 } \\
\text { Polygonatum }\end{array}$ & P. zanlanscianense Pamp. & 重庆金佛山 Jinfo Mt., Chongqing & & 30 & 15 & $2 \mathrm{x}$ & 2,050 & PH & NT & Deng et al, 2009 \\
\hline $\begin{array}{l}\text { 天门冬科 } \\
\text { Asparagaceae }\end{array}$ & $\begin{array}{l}\text { 黄精属 } \\
\text { Polygonatum }\end{array}$ & P. zanlanscianense Pamp. & 重庆金佛山 Jinfo Mt., Chongqing & & 30 & 15 & $2 \mathrm{x}$ & 2,100 & $\mathrm{PH}$ & NT & Deng et al, 2009 \\
\hline $\begin{array}{l}\text { 天门冬科 } \\
\text { Asparagaceae }\end{array}$ & $\begin{array}{l}\text { 黄精属 } \\
\text { Polygonatum }\end{array}$ & P. zanlanscianense Pamp. & 重庆金佛山 Jinfo Mt., Chongqing & & 30 & 15 & $2 \mathrm{x}$ & 2,130 & PH & NT & Deng et al, 2009 \\
\hline 天南星科 Araceae & 芋属 Colocasia & C. gaoligongensis H. Li \& C. L. Long & 云南腾冲 Tengchong, Yunnan & & 28 & 14 & $2 \mathrm{x}$ & 3,700 & $\mathrm{PH}$ & TA & Yang et al, 2003 \\
\hline 天南星科 Araceae & 芋属 Colocasia & $\begin{array}{l}\text { C. gaoligongnensis H. Li et C. L. } \\
\text { Long }\end{array}$ & 云南沪水 Lushui, Yunnan & & 28 & 14 & $2 \mathrm{x}$ & 1,650 & $\mathrm{PH}$ & TA & $\begin{array}{l}\text { 曹利民和龙春林, } \\
2004\end{array}$ \\
\hline 天南星科 Araceae & 芋属 Colocasia & C. leucophloea Komarov Trudy & $\begin{array}{l}\text { 新疆吉木乃口岸附近 Jeminay, } \\
\text { Xinjiang }\end{array}$ & & 32 & 16 & $4 \mathrm{x}$ & 750 & $\mathrm{~W}$ & TA & 常朝阳等, 2009 \\
\hline 天南星科 Araceae & 芋属 Colocasia & C. licentiana Handel-Mazzetti & 四川红原 Hongyuan, Sichuan & & 16 & 8 & $2 \mathrm{x}$ & 3,300 & $\mathrm{~W}$ & $\mathrm{TA}$ & 常朝阳等, 2009 \\
\hline 天南星科 Araceae & 芋属 Colocasia & C. opulens Komarov Trudy & 甘肃卓尼 Zhuoni, Gansu & & 16 & 8 & $2 \mathrm{x}$ & 2,500 & $\mathrm{~W}$ & TA & 常朝阳等, 2009 \\
\hline 天南星科 Araceae & 芋属 Colocasia & C. tragacanthoides (Pallas) Poiret & 甘肃兰州 Lanzhou, Gansu & & 16 & 8 & $2 \mathrm{x}$ & 1,600 & $\mathrm{~W}$ & $\mathrm{TA}$ & 常朝阳等, 2009 \\
\hline 天南星科 Araceae & 岩芓属 Remusatia & R. hookeriana Schott & 云南贡山 Gongshan, Yunnan & & 10 & 5 & $2 \mathrm{x}$ & 2,300 & $\mathrm{PH}$ & OWT & 顾志建等, 1992 \\
\hline 天南星科 Araceae & 岩芋属 Remusatia & R. hookeriana Schott Oesterr & 云南大理 Dali, Yunnan & & 28 & 14 & $2 \mathrm{x}$ & & $\mathrm{PH}$ & TA to TA & 龙春林等, 1989 \\
\hline 天南星科 Araceae & 岩芋属 Remusatia & R. vivipara Schott & 云南大理 Dali, Yunnan & & 42 & 14 & $3 \mathrm{x}$ & & $\mathrm{PH}$ & TA to TA & 李恒和 Hay, 1992 \\
\hline 天南星科 Araceae & 岩芋属 Remusatia & R. vivipara Schott Oesterr & 云南大理 Dali, Yunnan & & 42 & 14 & $3 \mathrm{x}$ & & $\mathrm{PH}$ & TA to TA & 龙春林等, 1989 \\
\hline 天南星科 Araceae & 天南星属 Arisaema & A. biauriculatum Buchet. & 西藏墨脱 Motuo, Tibet & & 28 & 14 & $2 \mathrm{x}$ & 1,100 & $\mathrm{PH}$ & NT & $\begin{array}{l}\text { 顾志建和孙先风, } \\
1998\end{array}$ \\
\hline 天南星科 Araceae & 天南星属 Arisaema & $\begin{array}{l}\text { A. biauriculatum W. W. Sm. ex Hand. } \\
\text {-Mazt. }\end{array}$ & 云南贡山 Gongshan, Yunnan & & 28 & 14 & $2 \mathrm{x}$ & 2,600 & PH & NT & 顾志建等, 1992 \\
\hline 天南星科 Araceae & 天南星属 Arisaema & A. dulongense $\mathrm{H} . \mathrm{Li}$ & 云南贡山 Gongshan, Yunnan & & 26 & 13 & $2 \mathrm{x}$ & 2,600 & $\mathrm{PH}$ & NT & 顾志建等, 1992 \\
\hline
\end{tabular}


王家坚, 彭智邦, 孙航, 聂泽龙, 孟盈. 青藏高原与横断山被子植物区系演化的细胞地理学特征. 生物多样性, 2017, 25 (2): 218-225.

http://www.biodiversity-science.net/CN/10.17520/biods.2016281

\begin{tabular}{|c|c|c|c|c|c|c|c|c|c|c|c|}
\hline 科名 Families & 属名 Genera & 种名 Species & 采集地点 Location & $\mathrm{n}$ & $2 n$ & $\mathrm{x}$ & $\begin{array}{l}\text { 倍性 } \\
\text { Ploidy }\end{array}$ & $\begin{array}{l}\text { 海拔 } \\
\text { Altitude } \\
\text { (m) }\end{array}$ & $\begin{array}{l}\text { 生活型 } \\
\text { Life form }\end{array}$ & $\begin{array}{l}\text { 分布型 } \\
\text { Areal-type }\end{array}$ & 参考文献 Reference \\
\hline 天南星科 Araceae & 天南星属 Arisaema & A. erubescens Schott & 云南贡山 Gongshan, Yunnan & & 56 & 14 & $4 \mathrm{x}$ & 2,300 & $\mathrm{PH}$ & NT & 顾志建等, 1992 \\
\hline 天南星科 Araceae & 天南星属 Arisaema & A. lobatum Engl. & 四川峨眉山 Emei Mt., Sichuan & & 56 & 14 & $4 \mathrm{x}$ & 1,700 & $\mathrm{PH}$ & NT & Hong \& Zhang, 1990 \\
\hline 天南星科 Araceae & $\begin{array}{l}\text { 蘑芋属 } \\
\text { Amorphophallus }\end{array}$ & A. bannanensis $\mathrm{H}$. Li & 云南贡山 Gongshan, Yunnan & & 26 & 13 & $2 \mathrm{x}$ & 1,280 & $\mathrm{PH}$ & TA to TA & 顾志建等, 1992 \\
\hline 天南星科 Araceae & 菖蒲属 Acorus & A. calamus $\mathrm{L}$. & 云南中甸 Zhongdian, Yunnan & & 66 & 11 & $6 \mathrm{x}$ & & $\mathrm{PH}$ & NT & 王红等, 2001 \\
\hline 天南星科 Araceae & $\begin{array}{l}\text { 斑龙芋属 } \\
\text { Sauromatum }\end{array}$ & S. gaoligongense Z. L. Wang \& H. Li & 云南保山 Baoshan, Yunnan & & 26 & 13 & $2 \mathrm{x}$ & 2,290 & $\mathrm{PH}$ & TA to TA & 市福花等, 2001 \\
\hline $\begin{array}{l}\text { 梧桐科 } \\
\text { Sterculiaceae }\end{array}$ & 昂天莲属 Ambroma & A. augusta & 四川康定 Kangding, Sichuan & & 16 & 8 & $2 \mathrm{x}$ & 900 & $\mathrm{AH}$ & $\mathrm{P}$ & 顾志建和孙航, 1998 \\
\hline $\begin{array}{l}\text { 五福花科 } \\
\text { Adoxaceae }\end{array}$ & 四福花属 Tetradoxa & T. ometensts (Hara) C. Y. Wu & 四川峨眉山 Emei Mt., Sichuan & & 36 & 18 & $2 \mathrm{x}$ & 2,300 & $\mathrm{PH}$ & EC & $\begin{array}{l}\text { 梁汉心和张香兰, } \\
1986\end{array}$ \\
\hline $\begin{array}{l}\text { 五福花科 } \\
\text { Adoxaceae }\end{array}$ & 华福花属 Sinadoxa & $\begin{array}{l}\text { S. corydalifolia Z. Y. Wu, Z. L. Wu \& } \\
\text { R. F. Huang }\end{array}$ & 青海玉树 Yushu, Qinghai & & 36 & 18 & $2 \mathrm{x}$ & & $\mathrm{PH}$ & $\mathrm{EC}$ & 卢学峰等, 2002a \\
\hline $\begin{array}{l}\text { 苋科 } \\
\text { Amaranthaceae }\end{array}$ & 杯苋属 Cyathula & C. officinalis Kuan. & 四川天全 Tianquan, Sichuan & & 34 & 17 & $2 \mathrm{x}$ & 1,400 & $\mathrm{PH}$ & TA to TA & 范巧佳等, 2009 \\
\hline $\begin{array}{l}\text { 苧科 } \\
\text { Amaranthaceae }\end{array}$ & 杯苋属 Cyathula & C. officinalis Kuan. & $\begin{array}{l}\text { 四川天全二郎山 Erlang Mt., } \\
\text { Tianquan, Sichuan }\end{array}$ & & 34 & 17 & $2 \mathrm{x}$ & 1,550 & $\mathrm{PH}$ & TA to TA & 范巧佳等, 2009 \\
\hline $\begin{array}{l}\text { 小檗科 } \\
\text { Berberidaceae }\end{array}$ & $\begin{array}{l}\text { 桃儿七属 } \\
\text { Sinopodophyllum }\end{array}$ & S. hexandrum (Royle) T. S. Ying & 云南中甸 Zhongdian, Yunnan & & 12 & 6 & $2 \mathrm{x}$ & 3,200 & $\mathrm{PH}$ & EA & $\begin{array}{l}\text { 马绍宾和胡志浩, } \\
1996\end{array}$ \\
\hline $\begin{array}{l}\text { 小檗科 } \\
\text { Berberidaceae }\end{array}$ & $\begin{array}{l}\text { 山荷叶属 } \\
\text { Diphylleia }\end{array}$ & D. sinensis H. L. Li J & 云南中甸 Zhongdian, Yunnan & & 12 & 6 & $2 \mathrm{x}$ & 3,200 & PH & $\begin{array}{l}\text { EA \& } \\
\text { NAD }\end{array}$ & $\begin{array}{l}\text { 马绍宾和胡志浩, } \\
1996\end{array}$ \\
\hline $\begin{array}{l}\text { 小檗科 } \\
\text { Berberidaceae }\end{array}$ & 鬼自属 Dysosma & $\begin{array}{l}\text { D. versipellis (Hance) M. Cheng ex T. } \\
\text { S. Ying }\end{array}$ & 四川峨眉山 Emei Mt., Sichuan & & 12 & 6 & $2 x$ & 805 & PH & EA & $\begin{array}{l}\text { 马绍宾和胡志浩, } \\
1996\end{array}$ \\
\hline
\end{tabular}


王家坚, 彭智邦, 孙航, 聂泽龙, 孟盈. 青藏高原与横断山被子植物区系演化的细胞地理学特征. 生物多样性, 2017, 25 (2): 218-225.

http://www.biodiversity-science.net/CN/10.17520/biods.2016281

\begin{tabular}{|c|c|c|c|c|c|c|c|c|c|c|c|}
\hline 科名 Families & 属名 Genera & 种名 Species & 采集地点 Location & $\mathrm{n}$ & $2 n$ & $\mathrm{x}$ & $\begin{array}{l}\text { 倍性 } \\
\text { Ploidy }\end{array}$ & $\begin{array}{l}\text { 海拔 } \\
\text { Altitude } \\
\text { (m) }\end{array}$ & $\begin{array}{l}\text { 生活型 } \\
\text { Life form }\end{array}$ & $\begin{array}{l}\text { 分布型 } \\
\text { Areal-type }\end{array}$ & 参考文献 Reference \\
\hline $\begin{array}{l}\text { 玄参科 } \\
\text { Scrophulariaceae }\end{array}$ & 倾草属 Valeriana & V. henryi T. Yamaz. & 四川宝兴 Baoxing, Sichuan & 12 & & 12 & $2 x$ & 2,600 & $\mathrm{~W}$ & TA & Hong \& Zhang, 1990 \\
\hline $\begin{array}{l}\text { 玄参科 } \\
\text { Scrophulariaceae }\end{array}$ & 倾草属 Valeriana & V. javanica Blume & 四川峨眉山 Emei Mt., Sichuan & & 32 & 8 & $4 \mathrm{x}$ & 1,700 & PH & NT & Hong \& Zhang, 1990 \\
\hline $\begin{array}{l}\text { 玄参科 } \\
\text { Scrophulariaceae }\end{array}$ & 倾草属 Valeriana & V. laxa Benth. & 四川峨眉山 Emei Mt., Sichuan & & 16 & 8 & $2 \mathrm{x}$ & 1,000 & PH & NT & Hong \& Zhang, 1990 \\
\hline $\begin{array}{l}\text { 玄参科 } \\
\text { Scrophulariaceae }\end{array}$ & 倾草属 Valeriana & V. serpyllifolia $\mathrm{L}$. & 四川宝兴 Baoxing, Sichuan & & 16 & 8 & $2 \mathrm{x}$ & 1,600 & PH & NT & Hong \& Zhang, 1990 \\
\hline $\begin{array}{l}\text { 罂粟科 } \\
\text { Papaveraceae }\end{array}$ & $\begin{array}{l}\text { 绿线蒿属 } \\
\text { Meconopsis }\end{array}$ & $\begin{array}{l}\text { M. horridula J. D. Hooker \& } \\
\text { Thomson }\end{array}$ & Zuogong, Tibet & & 28 & 14 & $2 \mathrm{x}$ & 3,620 & PH & NT & Meng et al, 2010 \\
\hline $\begin{array}{l}\text { 罂粟科 } \\
\text { Papaveraceae }\end{array}$ & $\begin{array}{l}\text { 绿线蒿属 } \\
\text { Meconopsis }\end{array}$ & M. integrifolia Franchet. & Zuogong, Tibet & & 56 & 14 & $4 \mathrm{x}$ & 5,094 & $\mathrm{PH}$ & NT & Meng et al, 2010 \\
\hline $\begin{array}{l}\text { 罂粟科 } \\
\text { Papaveraceae }\end{array}$ & $\begin{array}{l}\text { 绿线蒿属 } \\
\text { Meconopsis }\end{array}$ & M. pseudovenusta G. Taylor & Rikaze, Tibet & & 28 & 14 & $2 \mathrm{x}$ & 4,653 & $\mathrm{PH}$ & NT & Meng et al, 2010 \\
\hline $\begin{array}{l}\text { 罂粟科 } \\
\text { Papaveraceae }\end{array}$ & $\begin{array}{l}\text { 绿线蒿属 } \\
\text { Meconopsis }\end{array}$ & M. racemosa Maximowicz. & Mangkang, Tibet & & 24 & 12 & $2 x$ & 4,000 & PH & NT & Meng et al, 2012 \\
\hline 忽尾科 Iridaceae & 惫尾属 Iris & I. bulleyana Dykes & 云南中甸 Zhongdian, Yunnan & & 40 & 20 & $2 \mathrm{x}$ & 3,330 & $\mathrm{PH}$ & NT & 沈云光等, 2007 \\
\hline 忽尾科 Iridaceae & 煘尾属 Iris & I. chrysographes Dykes & $\begin{array}{l}\text { 云南丽江三道湾 Sandaowan, } \\
\text { Lijiang, Yunnan }\end{array}$ & & 40 & 20 & $2 x$ & 3,200 & $\mathrm{PH}$ & NT & 沈云光等, 2007 \\
\hline 茑尾科 Iridaceae & 煘尾属 Iris & I. collettii Hook. f. & $\begin{array}{l}\text { 云南丽江甘海子 Ganhaizi, Lijiang, } \\
\text { Yunnan }\end{array}$ & & 28 & 14 & $2 x$ & 3,070 & PH & NT & 沈云光等, 2007 \\
\hline 㶡尾科 Iridaceae & 㚜尾属 Iris & I. cuniculiformis Noltie \& K. & 云南中甸 Zhongdian, Yunnan & & 22 & 11 & $2 \mathrm{x}$ & 3,330 & $\mathrm{PH}$ & NT & 沈云光等, 2007 \\
\hline 洬尾科 Iridaceae & 茑尾属 Iris & I. delavayi Mich. & 云南大理苍山 Cang Mt., Dali, & & 40 & 20 & $2 \mathrm{x}$ & 3,050 & PH & NT & 沈云光等, 2007 \\
\hline
\end{tabular}


王家坚, 彭智邦, 孙航, 聂泽龙, 孟盈. 青藏高原与横断山被子植物区系演化的细胞地理学特征. 生物多样性, 2017, 25 (2): 218-225.

http://www.biodiversity-science.net/CN/10.17520/biods.2016281

\begin{tabular}{|c|c|c|c|c|c|c|c|c|c|c|c|}
\hline 科名 Families & 属名 Genera & 种名 Species & 采集地点 Location & $\mathrm{n}$ & $2 n$ & $\mathrm{x}$ & $\begin{array}{l}\text { 倍性 } \\
\text { Ploidy }\end{array}$ & $\begin{array}{l}\text { 海拔 } \\
\text { Altitude } \\
\text { (m) }\end{array}$ & $\begin{array}{l}\text { 生活型 } \\
\text { Life form }\end{array}$ & $\begin{array}{l}\text { 分布型 } \\
\text { Areal-type }\end{array}$ & 参考文献 Reference \\
\hline & & & Yunnan & & & & & & & & \\
\hline 鸲尾科 Iridaceae & 兽尾属 Iris & I. dolichosiphon Noltie & 云南小中甸 Xiaozhongdian, Yunnan & & 22 & 11 & $2 \mathrm{x}$ & 3,280 & PH & NT & 沈云光等, 2007 \\
\hline 密尾科 Iridaceae & 苮尾属 Iris & I. forrestii Dykes & $\begin{array}{l}\text { 云南丽江三道湾 Sandaowan, } \\
\text { Lijiang, Yunnan }\end{array}$ & & 40 & 20 & $2 \mathrm{x}$ & 3,020 & $\mathrm{PH}$ & NT & 沈云光等, 2007 \\
\hline 㚜尾科 Iridaceae & 惑尾属 Iris & I. forrestii Dykes & 云南宁菠沪沽湖 Ninglang, Yunnan & & 40 & 20 & $2 \mathrm{x}$ & 2,700 & PH & NT & 沈云光等, 2007 \\
\hline 芻尾科 Iridaceae & 荅尾属 Iris & I. laevigata Fisch. & $\begin{array}{l}\text { 云南腾冲北海湖 Tengchong, } \\
\text { Yunnan }\end{array}$ & & 32 & 16 & $2 \mathrm{x}$ & 1,700 & $\mathrm{PH}$ & NT & 沈云光等, 2007 \\
\hline 茑尾科 Iridaceae & 茴尾属 Iris & I. ruthenica var. nana Maxim. & $\begin{array}{l}\text { 云南中甸尼西 Nixi, Zhongdian, } \\
\text { Yunnan }\end{array}$ & & 42 & 21 & $2 \mathrm{x}$ & 3,630 & $\mathrm{PH}$ & NT & 沈云光等, 2007 \\
\hline 茑尾科 Iridaceae & 茑尾属 Iris & I. ruthenica var. nana Maxim. & $\begin{array}{l}\text { 云南丽江甘海子 Ganhaizi, Lijiang, } \\
\text { Yunnan }\end{array}$ & & 42 & 21 & $2 \mathrm{x}$ & 3,200 & $\mathrm{PH}$ & NT & 沈云光等, 2007 \\
\hline 㫭尾科 Iridaceae & 感尾属 Iris & I. ruthenica var. nana Maxim. & 云南中甸 Zhongdian, Yunnan & & 42 & 21 & $2 \mathrm{x}$ & 3,330 & $\mathrm{PH}$ & NT & 沈云光等, 2007 \\
\hline 鸢尾科 Iridaceae & 荅尾属 Iris & I. subdichotoma Y. T. Zhao & $\begin{array}{l}\text { 云南中甸三坝 Sanba, Zhongdian, } \\
\text { Yunnan }\end{array}$ & & 42 & 21 & $2 \mathrm{x}$ & 1,940 & $\mathrm{PH}$ & NT & 沈云光等, 2007 \\
\hline 樟科 Lauraceae & 樟属 Cinnamomum & $\begin{array}{l}\text { C. longipaniculatum (Gamble) N. } \\
\text { Chao ex H. W. Li }\end{array}$ & 四川都江堰 Dujiangyan, Sichuan & & 24 & 12 & $2 \mathrm{x}$ & & $\mathrm{W}$ & $\begin{array}{l}\text { EA \& } \\
\text { NAD }\end{array}$ & 陈成涁等, 1998 \\
\hline 樟科 Lauraceae & 山胡椒属 Lindera & L. communis Hemsl. & 四川都江堰 Dujiangyan, Sichuan & & 24 & 12 & $2 \mathrm{x}$ & & $\mathrm{W}$ & $\begin{array}{l}\text { EA \& } \\
\text { NAD }\end{array}$ & 陈成彬等, 1998 \\
\hline 樟科 Lauraceae & 山胡椒属 Lindera & L. megaphylla Hemsl. & 四川都江堰 Dujiangyan, Sichuan & & 24 & 12 & $2 \mathrm{x}$ & & $\mathrm{W}$ & $\begin{array}{l}\text { EA \& } \\
\text { NAD }\end{array}$ & 陈成彬等, 1998 \\
\hline 樟科 Lauraceae & 山胡椒属 Lindera & $\begin{array}{l}\text { L. pulcherrima (Nees) Benth. ex } \\
\text { Hook. f. }\end{array}$ & 四川都江堰 Dujiangyan, Sichuan & & 24 & 12 & $2 \mathrm{x}$ & & $\mathrm{W}$ & $\begin{array}{l}\text { EA \& } \\
\text { NAD }\end{array}$ & 陈成彬等, 1998 \\
\hline 紫草科 & 微孔草属 Microula & M. tibetica Benth & 新疆伊犁 Ili, Xinjiang & & 24 & 12 & $2 \mathrm{x}$ & 5,000 & PH & NT & 顾志建等, 1993 \\
\hline
\end{tabular}


王家坚, 彭智邦, 孙航, 聂泽龙, 孟盈. 青藏高原与横断山被子植物区系演化的细胞地理学特征. 生物多样性, 2017, 25 (2): 218-225.

http://www.biodiversity-science.net/CN/10.17520/biods.2016281

\begin{tabular}{|c|c|c|c|c|c|c|c|c|c|c|c|}
\hline 科名 Families & 属名 Genera & 种名 Species & 采集地点 Location & $\mathrm{n}$ & $2 n$ & $\mathrm{x}$ & $\begin{array}{l}\text { 倍性 } \\
\text { Ploidy }\end{array}$ & $\begin{array}{l}\text { 海拔 } \\
\text { Altitude } \\
\text { (m) }\end{array}$ & $\begin{array}{l}\text { 生活型 } \\
\text { Life form }\end{array}$ & $\begin{array}{l}\text { 分布型 } \\
\text { Areal-type }\end{array}$ & 参考文献 Reference \\
\hline \multicolumn{12}{|l|}{ Boraginaceae } \\
\hline $\begin{array}{l}\text { 紫草科 } \\
\text { Boraginaceae }\end{array}$ & 软紫草属 Arnebia & A. euchroma Johnston. & 新疆温泉县 Wenquan, Xinjiang & & 14 & 7 & $2 \mathrm{x}$ & 2,600 & PH & OWT & $\begin{array}{l}\text { 房淑敏和张海道, } \\
1992\end{array}$ \\
\hline $\begin{array}{l}\text { 紫堇科 } \\
\text { Fumariaceae }\end{array}$ & 紫堇属 Corydalis & C. omeiana H. Tsaung & 四川宝兴 Baoxing, Sichuan & 9 & & 9 & $2 \mathrm{x}$ & 1,500 & $\mathrm{AH}$ & C & Hong \& Zhang, 1990 \\
\hline $\begin{array}{l}\text { 紫蒇科 } \\
\text { Bignoniaceae }\end{array}$ & 角蒿属 Incarvillea & I. arguta Royle & 云南中甸 Zhongdian, Yunnan & & 22 & 11 & $2 \mathrm{x}$ & & $\mathrm{PH}$ & $\mathrm{P}$ & Chen et al, 2004 \\
\hline $\begin{array}{l}\text { 紫葳科 } \\
\text { Bignoniaceae }\end{array}$ & 角蒿属 Incarvillea & I. berezovskii Batalin & 四川马尔康 Maerkang, Sichuan & & 22 & 11 & $2 \mathrm{x}$ & & $\mathrm{PH}$ & $\mathrm{P}$ & Chen et al, 2004 \\
\hline $\begin{array}{l}\text { 紫葳科 } \\
\text { Bignoniaceae }\end{array}$ & 角蒿属 Incarvillea & I. compacta Maxim. & 四川石渠 Shiqu, Sichuan & & 22 & 11 & $2 \mathrm{x}$ & & $\mathrm{PH}$ & $\mathrm{P}$ & Chen et al, 2004 \\
\hline $\begin{array}{l}\text { 紫葳科 } \\
\text { Bignoniaceae }\end{array}$ & 角蒿属 Incarvillea & I. delavayi Bur. et Franch. & 云南丽江 Lijiang, Yunnan & & 22 & 11 & $2 \mathrm{x}$ & & PH & $\mathrm{P}$ & Chen et al, 2004 \\
\hline $\begin{array}{l}\text { 紫藏科 } \\
\text { Bignoniaceae }\end{array}$ & 角蒿属 Incarvillea & I. dissectifolia Q. S. Zhao & 四川盐源 Yanyuan, Sichuan & & 22 & 11 & $2 \mathrm{x}$ & & PH & $\mathrm{P}$ & Chen et al, 2004 \\
\hline $\begin{array}{l}\text { 紫藏科 } \\
\text { Bignoniaceae }\end{array}$ & 角蒿属 Incarvillea & I. forrestii Fletcher & 云南中甸 Zhongdian, Yunnan & & 22 & 11 & $2 \mathrm{x}$ & & $\mathrm{PH}$ & $\mathrm{P}$ & 肖华等, 2002 \\
\hline $\begin{array}{l}\text { 紫藏科 } \\
\text { Bignoniaceae }\end{array}$ & 角蒿属 Incarvillea & I. lutea Bur. et Franch. & 四川稻城 Daocheng, Sichuan & & 22 & 11 & $2 \mathrm{x}$ & & $\mathrm{PH}$ & $\mathrm{P}$ & Chen et al, 2004 \\
\hline $\begin{array}{l}\text { 紫葳科 } \\
\text { Bignoniaceae }\end{array}$ & 角蒿属 Incarvillea & I. lutea Bureau \& Franch. & 云南丽江 Lijiang, Yunnan & & 22 & 11 & $2 \mathrm{x}$ & & $\mathrm{PH}$ & $\mathrm{P}$ & 肖华等, 2002 \\
\hline $\begin{array}{l}\text { 紫藏科 } \\
\text { Bignoniaceae }\end{array}$ & 角蒿属 Incarvillea & I. mairei (H. Lév.) Griers. & 云南中甸 Zhongdian, Yunnan & & 22 & 11 & $2 \mathrm{x}$ & & PH & $\mathrm{P}$ & 肖华等, 2002 \\
\hline
\end{tabular}


王家坚, 彭智邦, 孙航, 聂泽龙, 孟盈. 青藏高原与横断山被子植物区系演化的细胞地理学特征. 生物多样性, 2017, 25 (2): 218-225.

http://www.biodiversity-science.net/CN/10.17520/biods.2016281

\begin{tabular}{|c|c|c|c|c|c|c|c|c|c|c|c|}
\hline 科名 Families & 属名 Genera & 种名 Species & 采集地点 Location & $\mathrm{n}$ & $2 \mathrm{n}$ & $\mathrm{x}$ & $\begin{array}{l}\text { 倍性 } \\
\text { Ploidy }\end{array}$ & $\begin{array}{l}\text { 海拔 } \\
\text { Altitude } \\
\text { (m) }\end{array}$ & $\begin{array}{l}\text { 生活型 } \\
\text { Life form }\end{array}$ & $\begin{array}{l}\text { 分布型 } \\
\text { Areal-type }\end{array}$ & 参考文献 Reference \\
\hline $\begin{array}{l}\text { 紫葳科 } \\
\text { Bignoniaceae }\end{array}$ & 角蒿属 Incarvillea & I. mairei var. grandiflora & 云南丽江 Lijiang, Yunnan & & 22 & 11 & $2 \mathrm{x}$ & & PH & $\mathrm{P}$ & Chen et al, 2004 \\
\hline $\begin{array}{l}\text { 紫葳科 } \\
\text { Bignnoniaceae }\end{array}$ & 角蒿属 Incarvillea & I. mairei var. mairei & 云南大理 Dali, Yunnan & & 22 & 11 & $2 \mathrm{x}$ & & PH & $\mathrm{P}$ & Chen et al, 2004 \\
\hline $\begin{array}{l}\text { 紫葳科 } \\
\text { Bignoniaceae }\end{array}$ & 角蒿属 Incarvillea & I. younghusbandii Sprague & 西藏聂拉木 Nielamu, Tibet & & 22 & 11 & $2 \mathrm{x}$ & & PH & $\mathrm{P}$ & Chen et al, 2004 \\
\hline $\begin{array}{l}\text { 紫葳科 } \\
\text { Bignoniaceae }\end{array}$ & 角蒿属 Incarvillea & I. zhongdianensis Grey-Wilson & 云南中甸 Zhongdian, Yunnan & & 22 & 11 & $2 \mathrm{x}$ & & PH & $\mathrm{P}$ & Chen et al, 2004 \\
\hline $\begin{array}{l}\text { 紫蔵科 } \\
\text { Bignoniaceae }\end{array}$ & 角蒿属 Incarvillea & I. zhongdianensis Grey-Wilson & 云南丽江 Lijiang, Yunnan & & 22 & 11 & $2 \mathrm{x}$ & & PH & $\mathrm{P}$ & 肖华等, 2002 \\
\hline
\end{tabular}


王家坚, 彭智邦, 孙航, 聂泽龙, 孟盈. 青藏高原与横断山被子植物区系演化的细胞地理学特征. 生物多样 性, 2017, 25 (2): 218-225.

http://www.biodiversity-science.net/CN/10.17520/biods.2016281

Reference for Chromosome dataset

染色体数据集参考文献

Akiyama S, Ohba H, Wakabayashi M (1990) Notes on the interspecific relationship in the genus Rodgersia (Saxifragaceae). Journal of Japanese Botany, 65, 328-338.

Áskell Löve (1985) Chromosome number reports LXXXIX. International Association for Plant Taxonomy, 34(4), 727-730.

Bian FH, Wang ZL, Li H, Guan KY (2001) Karyotypic studies on two species in the genus Sauromatum (Araceae). Acta Botanica Yunnanica, 23, 473-478. (in Chinese with English abstract) [市福花, 王仲朗, 李 恒，管开云 (2001) 天南星科斑龙芋属植物的核型研究. 云南植物研究, 23, 473-478.]

Cai J, Hong W, Gu ZJ, Mill RR, Li DZ (2004) Karyotype morphology of thirteen species of Pedicularis (Orobanchaceae) from the Hengduan Mountains Region, NW Yunnan, China. Caryologia, 57, 337-347.

Cai LB, Feng HS (1997) Study on karyotype of 3 species of Elymus. Acta Botanica Boreali-Occidentalia Sinica, 17, 238-241. (in Chinese with English abstract) [蔡联炳, 冯海生 (1997) 披碱草属 3 个种的核型研究. 西 北植物学报, 17, 238-241.]

Cai SY, Gong S, Mei ZQ, Yu HQ (2011) Karyotype studies on Luzhou (Sichuan) Pterocypsela indica (Compositae). Journal of Luzhou Medical College, 34, 663-665. (in Chinese with English abstract) [蔡仕钰, 龚舒，梅志强，于海清 (2011) 四川泸州翅果菊的核型研究. 泸州医学院学报, 34, 663-665.]

Cao LM, Long CL (2004) Chromosome numbers of eight Colocasia taxa and karyotypes of five species occurring in China. Acta Botanica Yunnanica, 26, 310-316. (in Chinese with English abstract) [曹利民, 龙 春林 (2004) 中国芋属植物染色体数目及 5 个种的核型报道. 云南植物研究, 26, 310-316.]

Cao M, Zhou ZK (2000) A karyotype analysis of 9 species of the Quercus from China. Guihaia, 20, 341-345, 390-392. (in Chinese with English abstract) [曹明, 周浙昆 (2000) 中国栋属九种植物的核型分析. 广西 植物, 20, 341-345, 390-392.]

Cao YL, Lu RS (1989) Karyotype analysis of Hippophae L. in China. Acta Phytotaxonomica Sinica, 27, $118-123$.

Chang ZY, Li B, Shi FC (2009) The chromosomes and karyotypes of some species in Caragana from China. Bulletrn of Botanical Research, 29, 18-24. (in Chinese with English abstract) [常朝阳，黎斌，石福臣 (2009) 锦鸡儿属植物一些种类的染色体数目及核型研究. 植物研究, 29, 18-24.]

Chen CB, Li XL, Sun CR, Song WQ, Chen RY (1998) Studies on the karyotype of 9 species of 5 genus of Lauraceae in China. Journal of Wuhan Botanical Research, 16, 219-222. (in Chinese with English abstract) [陈成涁，李秀兰，孙成仁，宋文芹，陈瑞阳 (1998) 中国樟科 5 属 9 种植物的核型研究. 武汉植物学研 究, 16, 219-222.]

Chen D (2014) Karyotype and seed morphology of seven species of Sorbus. Master Thesis, Nanjing Forestry University. (in Chinese with English abstract) [陈丹 (2014) 7 种花楸属植物核型和种子形态学研究. 硕士 学位论文, 南京林业大学.]

Chen GF, Ba LJ, Sun WG, Lou X, Zhang JW, Li ZM (2013) Karyotypes and chromosome numbers of eight species from the family Asteraceae in the Hengduan Mountains and the adjacent regions. Plant Diversity, 35, 367-374. (in Chinese with English abstract) [陈光富, 巴罗菊, 孙文光, 娄笑, 张建文, 李志敏 (2013) 横 断山及邻近地区八种菊科植物的染色体数目及核型. 植物分类与资源学报, 35, 367-374.]

Chen GF, Sun WG, Hong DY, Zhou Z, Niu Y, Nie ZL, Sun H, Zhang JW, Li ZM (2014) Systematic significance of cytology in Cyananthus (Campanulaceae) endemic to the Sino-Himalayan Region. Journal of Systematics 
王家坚, 彭智邦, 孙航, 聂泽龙, 孟盈. 青藏高原与横断山被子植物区系演化的细胞地理学特征. 生物多样 性, 2017, 25 (2): 218-225.

http://www.biodiversity-science.net/CN/10.17520/biods.2016281 and Evolution, 52, 260-270.

Chen JG, Xu B, Li ZM, Sun H (2010) Karyological studies on two species of Compositae from the Hengduan Mountains, SW China. Guihaia, 30, 51-54. (in Chinese with English abstract) [陈建国, 徐波, 李志敏, 孙 航 (2010) 横断山区两种菊科植物的核型研究. 广西植物, 30, 51-54.]

Chen SF (1989) Karyotype analysis of species of Polygonatum Mill. Acta Phytotaxonomica Sinica, 27, 39-48. (in Chinese with English abstract) [陈少风 (1989) 黄精属八种植物的染色体研究. 植物分类学报, 27, 39-48.]

Chen SL, He TN, Liu JQ (1997) The chromosome number of eight species in Gentiana (Gentianaceae) from alpine mountains of the western China. Acta Botanica Boreali-Occidentalia Sinica, 17, 547-550. (in Chinese with English abstract) [陈世龙, 何廷农, 刘建全 (1997) 中国西部高山 8 种龙胆属植物的染色体数目. 西北植物学报, 17, 547-550.]

Chen ST, Zhou ZK, Guan KY, Nakata M (2004) Karyomorphology of Incarvillea (Bignoniaceae) and its implications in distribution and taxonomy. Botanical Journal of the Linnean Society, 144, 113-121.

Chen ZY, Chen SZ, Huang XX, Huang SF (1988) A report on chromosome numbers on Chinese Zingiberaceae (5). Guihaia, 8, 143-147. (in Chinese with English abstract) [陈忠毅, 陈升振, 黄向旭, 黄少甫 (1988) 国 产姜科植物的染色体计数(5). 广西植物, 8, 143-147.]

Chin HC, Chang MC, Ling PP, Ting GT, Dou FP (1985) A cytotaxonomic study on Chinese Dioscorea L.-The chromosome number and their relation to the origin and evolution of the genus. Acta Phytotaxonomica Sinica, 23, 11-18. (in Chinese with English abstract) [秦慧贞, 张美珍, 凌苹苹, 丁志遵, 窦方平 (1985) 中国薯 蓣属细胞分类的研究——染色体数与该属起源和演化. 植物分类学报, 23, 11-18.]

Chin HC, Pan ZH, She ML, Wu ZJ (1989) A report on chromosome number of Chinese Umbelliferae. Acta Phytotaxonomica Sinica, 27, 268-272. (in Chinese with English abstract) [秦慧贞, 潘泽惠, 余孟兰, 吴竹 君 (1989) 伞形科植物染色体数目报告. 植物分类学报, 27, 268-272.]

Cui XJ (1987) Karyotype analysis of 3 spesies of genus Podocarpium and chromosome number of 2 species of genus Desmodium. Bulletin of Botanical Research, 7, 123-130. (in Chinese with English abstract) [崔现举 (1987) 长柄山蚂蝗属三个种的核型分析及山蚂蝗属两个种的染色体数. 植物研究, 7, 123-130.]

Deng T, Meng Y, Sun H, Nie ZL (2011) Chromosome counts and karyotypes in Chaetoseris and Stenoseris (Asteraceae-Cichorieae) from the Hengduan Mountains of SW China. Journal of Systematics and Evolution, 49, 339-346.

Deng XL, He XJ, He WL, Gao YD, Liu HY, Zhang YC (2009) Karyotype and cytogeography of the genus Heracleum (Apiaceae) in the Hengduan Mountains. Journal of Systematics and Evolution, 47, 273-285.

Deng YF, Liao L, Li TJ, Wang SZ, Dang CQ, Xu LL (2013) The species diversity of three species of Ranunculus. Jiangsu Agricultural Sciences, 41, 336-339. (in Chinese with English abstract) [邓院芳, 廖亮, 李同建，汪 诗泽，党成强，徐玲玲 (2013) 3 种毛茛属植的物种内核型多样性. 江苏农业科学, 41, 336-339.]

Deng XY, Wang Q, He XJ (2009) Karyotypes of 16 populations of eight species in the genus Polygonatum (Asparagaceae) from China. Botanical Journal of the Linnean Society 159, 245-254.

Ding CB (2004) Studies on Biosystematics of Pseudoroegneria (Poaceae: Triticeae). PhD dissertation, Sichuan Agricultural University. (in Chinese with English abstract) [丁春邦 (2004) 拟我观草属植物的生物系统学 研究. 博士学位论文, 四川农业大学.]

Ding KY, Ge S, Hong DY, Yu ZH (1998) Cytotype variation and cytogeography of Scilla sineasis (Louriro) Merrill (Hyacinthaceae) in China. Hereditas, 129, 151-160.

Du N, Gu ZJ (2004) A comparative karyological study of the cultured Eutrema wasabi and its three related wild species. Acta Botanica Yunnanica, 26, 645-650. (in Chinese with English abstract) [杜宁，顾志建 (2004) 栽培山㟘菜与三个野生种的核型比较. 云南植物研究, 26, 645-650.] 
王家坚, 彭智邦, 孙航, 聂泽龙, 孟盈. 青藏高原与横断山被子植物区系演化的细胞地理学特征. 生物多样 性, 2017, 25 (2): 218-225.

http://www.biodiversity-science.net/CN/10.17520/biods.2016281

Fang SM, Zhang HD (1992) Karyotypic analysis of Arnebia euchroma and Arnebia guttata. Journal of Wuhan Botanical Research, 10, 176-178. (in Chinese with English abstract) [房淑敏, 张海道 (1992) 软紫草和黄 花软紫草的核型研究. 武汉植物学研究, 10, 176-178.]

Fang YX (1989) Cyto-geographical study on Polygonatum odoratum. Journal of Ecology, 8, 8-10. (in Chinese with English abstract) [方永釒金 (1989) 玉竹的细胞地理学研究. 生态学杂志, 8, 8-10.]

Fan QJ, Tian ML, Yin RX, Luo X (2009) Chromosome karyotype analysis of Cyathula officinalis Kuan. Journal of Sichuan Agricultural University, 27, 279-283. (in Chinese with English abstract) [范巧佳，田孟良，尹若 熙, 罗曦 (2009) 川牛膝染色体核型分析. 四川农业大学学报, 27, 279-283.]

Fan XF, Guo XQ, Li SW (2000) The studies on the karyotype diversity of 4 species of Liliaceae in Ziwu Mountain. Acta Botanica Boreali-Occidentalia Sinica, 20, 882-888. (in Chinese with English abstract) [范小 峰, 郭小强, 李师翁 (2000) 子午岭产 4 种百合科植物的核型多样性研究. 西北植物学报, 20, 882-888.]

Feng DX, Dang CL (2002) Karyotype and allozyme analyses of three populations of Erigeron breviscapus from Yunnan. Plant Diversity, 24, 754-758. (in Chinese with English abstract) [冯定霞, 党承林 (2002) 短葶飞 蓬云南三个种群的核型与等位酶分析. 植物分类与资源学报, 24, 754-758.]

Fu CX, Shen CD, Hong DY (1993) Variation and evolution of the karyotype on Smilax L. Cathaya, 5, 151-166. (in Chinese with English abstract) [傅承新, 沈朝栋, 洪德元 (1993) 菝荰属的核型变异和进化. Cathaya, 5, 151-166.]

Fu CX, Shen CD, Huang AJ (1995) The chromosome numbers of 11 species in Smilax L. and Heterosmilax Kunth. Journal of Wuhan Botanical Research, 13, 185-187. (in Chinese with English abstract) [傅承新, 沈 朝栋, 黄爱军 (1995) 茏苇属和肖菝契属 11 个种的染色体数目. 武汉植物学研究, 13, 185-187.]

Fu CX, Shen CD, Zhong GD, Hong DY (1992) The chromosome numbers of 7 species in Smiax L. Journal of Wuhan Botanical Research, 10, 381-382. (in Chinese with English abstract) [傅承新, 沈朝栋, 钟国庆, 洪 德元 (1992) 菝荰属 7 个种的染色体数目. 武汉植物学研究, 10, 381-382.]

Gao BC, Tang Y, Guo WH (1993) A cytological study on Acanthochlamys bracteata P. C. Kao (Acanthochlamyaceae). Acta Phytotaxonomica Sinica, 31, 42-44. (in Chinese with English abstract) [高宝纯, 唐亚, 郭卫红 (1993) 芒苍草的细胞学研究. 植物分类学报, 31, 42-44.]

Gao LM (2002) The Phylogeny and Geographical Distribution on Rhododendron and Azaleastrum (generalized). $\mathrm{PhD}$ Dissertation, Kunming Institute of Botany, Kunming. (in Chinese with English abstract) [高连明 (2002) 杜鹃属马银花亚属(广义)的系统发育与地理分布. 博士学位论文, 中国科学院昆明植物研究所, 昆明.]

Gao TP, Wang ZL, Guo HQ, Wang YF, Fang XW (2008) Karyotypes of 3 species of Saussurea in eastern of Tibet Plateau. Acta Prataculturae Sinica, 18, 169-174. (in Chinese with English abstract) [高天鹏, 王转莉, 郭怀 清, 王一峰, 方向文 (2008) 青藏高原东缘 3 种风毛菊属植物的核型研究. 草业学报, 18, 169-174.]

Gao XF, Chen SK, Gu ZJ, Zhao JZ (1995) A chromosomal study on the genus Gynostemma (Cucurbitaceae). Acta Botanica Yunnanica, 17, 312-316. (in Chinese with English abstract) [高信芬, 陈书坤, 顾志建, 赵加 治 (1995) 绞股蓝属的染色体研究. 云南植物研究, 17, 312-316.]

Gao YD, Zhou SD, He XJ (2009) Karyotypes of four genus in Liliaceae (s. str.) from Hengduan Mountains of Southwestern China. Acta Botanica Yunnanica, 31, 399-405. (in Chinese with English abstract) [高云东, 周 颂东, 何兴金 (2009) 中国横断山区狭义百合科四属部分植物核型研究. 云南植物研究, 31, 399-405.]

Gao YD, Zhou SD, He XJ (2011) Karyotype studies in thirty-two species of Lilium (Liliaceae) from China. Nordic Journal of Botany, 29, 746-761.

Gong X, Gu ZJ, Wu QA (1991) A cytological study of seven populations in Paeonia delavayi var. lutea. Acta Botanica Yunnanica, 13, 402-410. (in Chinese with English abstract) [龚洵, 顾志建 (1991) 黄牡丹七个居 群的细胞学研究. 云南植物研究, 13, 402-410.]

Gong X, Gu ZJ, Lu YX, Zhang CQ (2001) The karyotypes of seven species in Ligularia. Acta Botanica 
王家坚, 彭智邦, 孙航, 聂泽龙, 孟盈. 青藏高原与横断山被子植物区系演化的细胞地理学特征. 生物多样 性, 2017, 25 (2): 218-225.

http://www.biodiversity-science.net/CN/10.17520/biods.2016281

Yunnanica, 23, 216-222. (in Chinese with English abstract) [龚洵, 顾志建, 鲁元学, 张长芹 (2001) 7 种曹 吾属植物的核型. 云南植物研究, 23, 216-222.]

Gong X, Xiao TJ, Gu ZJ, Lu YX (1999) Giemsa C-banding patterns in 8 populations of Paeonia delavayi var. lutea. Acta Botanica Yunnanica, 21, 477-482. (in Chinese with English abstract) [龚洵, 肖调江, 顾志建, 鲁元学 (1999) 黄牡丹八个居群的 Giemsa C-带比较研究. 云南植物研究, 21, 477-482.]

Gu ZJ, Na HY (1986) Karyotype studies in eight taxa of Paris. Acta Botanica Yunnanica, 8, 313-318. (in Chinese with English abstract) [顾志建, 纳海燕 (1986) 几种重楼的染色体核型研究. 云南植物研究, 8, 313-318.]

Gu ZJ, Sun H (1998) The chromosome report of some plants from Motuo, Xizang (Tibet). Acta Botanica Yunnanica, 20, 207-210. [顾志建, 孙航 (1998) 西藏墨脱地区一些植物的染色体报道. 云南植物研究, 20, 207-210]

Gu ZJ, Sun XF (1997) A karyomorphological study of seventeen species of Chinese Camellia. Acta Botanica Yunnanica, 19, 159-170. (in Chinese with English abstract) [顾志建, 孙先凤 (1997) 山茶属 17 个种的核 形态学研究. 云南植物研究, 19, 159-170.]

Gu ZJ, Wang L, Li H (1992) Karyomorphological studies of some monocots in Dulongjiang area. Acta Botanica Yunnanica, 5, 77-90. (in Chinese with English abstract) [顾志建, 王丽, 李恒 (1992) 独龙江地区部分单 子叶植物的细胞形态学研究. 云南植物研究, 5, 77-90.]

Gu ZJ, Wang L, Gong X, Xiao TJ (1993) A cytological study of six populations of Disporum cantoniense (Liliaceae). Acta Phytotaxonomica Sinica, 31, 399-404. (in Chinese with English abstract) [顾志建, 王丽, 龚洵，肖调江 (1993) 万寿竹六个居群的核型研究. 植物分类学报, 31, 399-404.]

Gu ZJ, Wang L, Sun H, Wu SG (1993) A cytological study of some plants from Tibetan Plateau. Acta Botanica Yunnanica, 15, 377-384. (in Chinese with English abstract) [顾志建, 王丽, 孙航, 武素功 (1993) 青藏高 原一些种子植物的核型研究. 云南植物研究, 15, 377-384.]

Gu ZJ, Xia LF, Xie LS (1988) Report on the chromosome numbers of some species of Camellia in China. Acta Botanica Yunnanica, 10, 291-296. (in Chinese with English abstract) [顾志建, 夏丽芳, 谢立山 (1988) 中 国部分山茶属植物的染色体数目报告. 云南植物研究, 10, 291-296.]

Gu ZJ, Yang QE, Kondo K (1990) A karyomorphological study on Disporopsis Hance in China. La Kromosomo II, 57, 1916-1925.

Han CY, Sun WB (2005) Karyotype of the 4 populations of Trigonobalanus doichangensis (Fagaceae), a rare and endangered plant in China. Acta Botanica Yunnanica, 27, 95-100. (in Chinese with English abstract) [韩春艳, 孙卫邦 (2005) 濒危植物三棱栋四个居群的核型. 云南植物研究, 27, 95-100.]

He TN, Liu JQ, Chen SL (2002) Contribution to thekaryomorphology of 7 species in Gentiana (Gentianaceae). Acta Biologica Plateau Sinica, 15, 67-75.

He TN, Liu JQ, Chen SL (2002) Reports on the chromosome numbers of 8 species in Gentiana (Gentianaceae). Acta Biologica Plateau Sinica, 15, 63-66.

He TN, Liu JQ, Chen SL, Xue CY, Liu SW (2002) Chromosomes of nine species of the genus Saussurea (Compositae) from Qinghai. Acta Biologica Plateau Sinica, 15, 77-82.

He TN, Wang W, Xue CY (1999) A karyomorphological study on 5 species of Swertia (Gentianaceae). Acta Botanica Boreali-Occidentalia Sinica, 19, 546-551. (in Chinese with English abstract) [何廷农，王伟，薛春 迎 (1999) 獐牙菜属 5 种植物的核型研究. 西北植物学报, 19, 546-551.]

He XJ, Pu FD, Wang PL, Wang YP (1994) Studies on karyotypes of the genus Heracleum from China. Acta Phytotaxonomica Sinica, 32, 32-40. (in Chinese with English abstract) [何兴金, 溥发鼎, 王萍莉, 王幼平 (1994) 中国独活属的核型研究. 植物分类学报, 32, 32-40.]

He XJ, Xu JM (2001) Karyotypes of 4 species in Allium sect. Haplostemon Boiss. from China. Acta 
王家坚, 彭智邦, 孙航, 聂泽龙, 孟盈. 青藏高原与横断山被子植物区系演化的细胞地理学特征. 生物多样 性, 2017, 25 (2): 218-225.

http://www.biodiversity-science.net/CN/10.17520/biods.2016281

Phytotaxonomica Sinica, 39, 423-432. (in Chinese with English abstract) [何兴金, 许介眉 (2001) 中国葱 属单生组 4 种植物的核型研究. 植物分类学报, 39, 423-432.]

He XL, Zhang MJ (2009) Chromosome number and karyotype of seven species from Seriphidium (Compositae). Acta Botanica Boreali-Occidentalia Sinica, 29, 1155-1161. (in Chinese with English abstract) [贺学礼, 张妙 娟 (2009) 7 种绢蒿属植物染色体数目和核型研究. 西北植物学报, 29, 1155-1161.]

Hong DY (1984) Chromosomes of six Fabaceous species from Baoxing County, Sichuan Province. Acta Phytotaxonomica Sinica, 22, 301-305. (in Chinese with English abstract) [洪德元 (1984) 四川宝兴地区几 种豆科植物的染色体. 植物分类学报, 22, 301-305.]

Hong DY, Pan KY, Rao GY (2001) Cytogeography and taxonomy of the Paeonia obovata polyploid complex (Paeoniaceae). Plant Systematics and Evolution, 227, 123-136.

Hong DY, Zhang SZ (1990) Observations on chromosomes of some plants from western Sichuan. Cathaya, 2, 191-197.

Hong DY, Zhu XY (1987) Cytotaxonomical studies on Liliaceae (s. l. ) (1). Report on karyotypes of 10 species of 6 genera. Acta Phytotaxonomica Sinica, 25, 245-253. (in Chinese with English abstract) [洪德元, 朱相云 (1987) 百合科细胞分类学研究(1). 重楼等 6 属 10 种的核型报道. 植物分类学报, 25, 245-253.]

Huang J, Chen Z, Xia ZH, Shang HW (2013) Chromosome karyotypes of Coptis species in China. Acta Botanica Boreali-Occidentalia Sinica, 33, 931-938. (in Chinese with English abstract) [黄瀷, 陈浙, 夏志华, 商晗武 (2013) 国产黄连属植物的染色体核型分析. 西北植物学报, 33, 931-938.]

Huang RF, Dang CL, Yu H (1996) Studies on karyotypes of two species with basic chromosome number seven. Acta Botanica Yunnanica, Suppl. VIII, 91-97. (in Chinese with English abstract) [黄瑞复, 党承林, 虞泓 (1996) 染色体基数为 7 的两种葱属植物的核型研究. 云南植物研究, 增刊VIII, 91-97.]

Huang RF (2003) Karyotypical studies of 6 species of Androsace (Primulaceae) in China with reference to their systematic significance. Acta Botanica Boreali-Occidentalia Sinica, 23, 1700-1712. (in Chinese with English abstract) [黄容福 (2003) 国产 6 种点地梅属植物的核型及其系统学意义. 西北植物学报, 23, 1700-1712.]

Huang RF, Li JF (1996) Karyotype and its differentiation studies in the four populations of Lilium duchartrei. Acta Botanica Yunnanica, 8, 15-22. (in Chinese with English abstract) [黄瑞复, 李劲峰 (1996) 宝兴百合 四个居群的核型及其分化研究. 云南植物研究, 8, 15-22.]

Huang RF (2001) Variation of karyotype and ploidy of Androsace yargongensis (Primulaceae) in three population in Q-Z Plateau. Acta Botanica Boreali-Occidentalia Sinica, 21, 526-531. (in Chinese with English abstract) [黄荣福 (2001) 雅江点地梅(报春花科) 3 个居群的核型和倍性变化. 西北植物学报, 21, 526-531.]

Huang RF, Wei RC, Yan YX (1985) Discovery of spontaneous triploid of Allium tuberosum. Journal of Wuhan Botanical Research, 3, 429-431. (in Chinese with English abstract) [黃瑞复, 魏蓉城, 晏一祥 (1985) 自然 三倍体非的发现. 武汉植物学研究, 3, 429-431.]

Huang RF, Wei RC, Xu JM (1996) A study of karyotypes on Allium hookeri and its variety Allium hookeri var. muliense. Acta Botanica Yunnanica, 8, 78-84. (in Chinese with English abstract) [黄瑞复, 魏蓉成, 许介眉 (1996) 宽叶非及其变种木里非的核型研究. 云南植物研究, 8, 78-84.]

Huang RF, Xu M, Yu H (1995) A study on karyotypes and their evolutionary trends in Allium sect. Bromatorrhiza Ekberg (Liliaceae). Cathaya, 7, 133-145.

Huang RF, Shen SD, Lu XF (1996) Studies of karyotype and evolutionary of 6 species in genus Pedicularis Linn. Acta Botanica Boreali-Occidentalia Sinica, 16, 73-80. (in Chinese with English abstract) [黄荣福, 沈颂东, 卢学峰 (1996) 马先蒿属 6 个种的核型与进化研究. 西北植物学报, 16, 73-80.]

Huang RF, Shen SD (1999) Studies of the karyotype and evolution for three endemic species of Ranunculaceae 
王家坚, 彭智邦, 孙航, 聂泽龙, 孟盈. 青藏高原与横断山被子植物区系演化的细胞地理学特征. 生物多样 性, 2017, 25 (2): 218-225.

http://www.biodiversity-science.net/CN/10.17520/biods.2016281

in Tibetan Plateau. Acta Botanica Boreali-Occidentalia Sinica, 19, 138-143. (in Chinese with English abstract) [黄荣福, 沈颂东 (1999) 青藏高原毛莨科 3 种特有植物核型和进化研究. 西北植物学报, 19, 138-143.]

Huang RF, Shen SD, Lu XF (1996) Studies on the chromosome number and polyploidy for a number of plants in the north-east Qinghai-Xizang Plateau. Acta Botanica Boreali-Occidentalia Sinica, 16, 310-318.

Hu YP, Xie XL, Wen Q, Zhao XD, Wang L, Li Y (2007) Studies on karyotypes of five populations of Rheum tanguticum (Polygonaceae). Acta Botanica Yunnanica, 29, 429-433. (in Chinese with English abstract) [胡延 萍, 谢小龙, 温泉, 赵旭东, 王莉, 李毅 (2007) 唐古特大黄五个居群的核型. 云南植物研究, 29, 429-433.]

Iwatsubo Y, Naruhashi N (1992) Cytotaxonomical studies of Rubus (Rosaceae) I. Chromosome numbers of 20 species and 2 natural hybrids. Journal of Japanese Botany, 67, 270-275.

Jiangsu Institute of Botany (1976) Studies on Chinese Dioscorea sect. Stenophora Pr. et Burk and their chromosome numbers. Journal of University of Chinese Academy of Sciences, 14, 65-72. (in Chinese with English abstract) [江苏省植物研究所薯蓣课题研究组 (1976) 中国薯蓣属根茎组植物的分类和染色体 数的研究. 中国科学院大学学报, 14, 65-72.]

Jian HY, Zhang H, Zhang T, Li SF, Wang QG, Yan HJ, Qiu XQ, Tang KX (2010) Karyotype analysis of different varieties on Rosa odorata Sweet. Journal of Plant Genetic Resources, 11, 457-461. (in Chinese with English abstract) [塞洪英, 张影, 张婷, 李树发, 王其刚, 晏慧君, 邱显钦, 唐开学 (2010) 香水月季(Rosa odorata Sweet)不同变种的染色体及核型分析. 植物遗传资源学报, 11, 457-461.]

Jing WC, Xu JM, Yang L (1999) A study on cytotaxonomy of section Anguinum of Allium. Acta Phytotaxonomica Sinica, 37, 20-34. (in Chinese with English abstract) [景望春, 许介眉, 杨蕾 (1999) 葱 属宽叶组植物细胞分类学研究. 植物分类学报, 37, 20-34.]

Jin X, Zhang T, Gu ZJ, Li DZ (2007) Cytological studies on the genus Holcoglossum (Orchidaceae). Botanical Journal of the Linnean Society, 154, 283-288.

Junko M, Siro K, Gu ZJ, Li H (1992) C-banding patterns in eighteen taxa of the genus Paris sensu Li, Liliaceae. Cytologia, 57, 181-194.

Kondo K, Tanaka R, Ge S, Hong DY, Nakata M (1992) Cytogenetic studies on wild Chrysanthemum sensu lato in China. IV. Karyomorphological characteristics of three species of Ajania. Journal of Japanese Botany, 67, 324-329.

Kondo K, Tanaka R, Hong DY, Hizume M, Yang QE, Nakata M (1995) Cytogenetic studies on wild Chrysanthemum sensu lato in China. V. A chromosome study of three species of Ajania, Cancrinia maximowiczii and Dendranthema lavandulifolium in the Chrysantheminae, the Anthemideae, the Compositae in Chinese Highlands. Journal of Japanese Botany, 70, 85-94.

Kong HZ (2000) Karyotypes of Sarcandra Gardn. and Chloranthus Swarts. (Chloranthaceae) from China. Botanical Journal of the Linnean Society, 133, 327-342. (in Chinese with English abstract) [孔宏智 (2000) 论金粟兰科的属间关系. 全国系统与进化植物学青年学术研讨会, 133, 327-342.]

Kong HZ, Liu JQ (1999) Karyomorphology of the genus Pomatosace Maxim. (Primulaceae). Acta Phytotaxonomica Sinica, 37, 445-450. (in Chinese with English abstract) [孔宏智, 刘建全 (1999) 中国特 有属——羽叶点地梅属的细胞学研究. 植物分类学报, 37, 445-450.]

Kong HZ, Yang QE (1997) Karyomorphology and relationship of the genus Circaeaster Maxim. Acta Phytotaxonomica Sinica, 35, 494-499. (in Chinese with English abstract) [孔宏智, 杨亲二 (1997) 星叶草 属的核形态及其系统位置. 植物分类学报, 35, 494-499.]

Kong WJ, Zhu LJ, Li ZM (2008) Studies on chromosome number and karyotype of Nepetasibirica. Journal of Yunnan Normal University, 28(5), 52-56. (in Chinese with English abstract) [孔维进, 朱丽娟, 李志敏 
王家坚, 彭智邦, 孙航, 聂泽龙, 孟盈. 青藏高原与横断山被子植物区系演化的细胞地理学特征. 生物多样 性, 2017, 25 (2): 218-225.

http://www.biodiversity-science.net/CN/10.17520/biods.2016281

(2008) 荆芥属大花荆芥(Nepetasibirica)的染色体数目及核型分析. 云南师范大学学报(自然科学版), 28(5), 52-56.]

Küpfer P, Yuan YM (1996) Karyological studies on Gentiana sect. Chondrophyllae (Gentianaceae) from China. Plant Systematics and Evolution, 200, 161-176.

Liang HX, Zhang XL (1986) Floral anatomy of Tetradoxa omeienis. Acta Botanica Yunnanica, 8, 436-440. (in Chinese with English abstract) [梁汉兴, 张香兰 (1986) 四福花花部解剖及维管系统的研究. 云南植物 研究, 8, 436-440.]

Liang GL, Li XL (1993) Chromosome studies of Chinese species of Malus Mill. Acta Phytotaxonomica Sinica 31, 236-251. (in Chinese with English abstract) [梁国鲁, 李晓林 (1993) 中国苹果属植物染色体研究. 植 物分类学报, 31, 236-251.]

Liang GL (1987) Observations of chromosomes of Malus species in China. Acta Phytotaxonomica Sinica, 25, 437-444. (in Chinese with English abstract) [梁国鲁 (1987) 中国苹果属染色体的观察. 植物分类学报, 25, 437-444.]

Liang QL, Wang CB, Ma XG, Zhao C, He XJ (2013) Chromosomal study on Chinese Bupleurum (Apiaceae). Plant Science Journal, 31(1), 11-22. (in Chinese with English abstract) [梁乾隆, 王长宝, 马祥光, 赵财, 何兴金 (2013) 中国柴胡属染色体数目和核型研究. 植物科学学报, 31(1), 11-22.]

Li B, Chang ZY, Wu ZH, Xu LR (2004) A karyotype study of six Astragalus species from China. Acta Botanica Boreali-Occidentalia Sinica, 24, 711-715. (in Chinese with English abstract) [黎斌，常朝阳，吴振海，徐朗 然 (2004) 国产 6 种黄耆属植物的核型研究. 西北植物学报, 24, 711-715.]

Li B, Yu H, Tang K (2004) Study on karyotypical variation in population of Lilium nepalense. Journal of Chongqing University of Posts and Telecommunications, 16(1), 98-102. (in Chinese with English abstract) [李标, 虞泓, 唐坤 (2004) 紫斑百合居群核型变异式样. 重庆邮电大学学报(自然科学版), 16(1), 98-102.]

Li H, Hay A (1992) Notes on the classification of genera Remusatia and Gonatanthus in Araceae. Acta Botanica Yunnanica, Suppl. 5, 27-33. (in Chinese with English abstract) [李恒, Hay A (1992) 天南星科岩芋属和曲 苍芋属的分类问题. 云南植物研究, 增刊 5, 27-33.]

Li H, Wang ZL, Gong HD, Wang YF (2008) A study on karyotypes of two Saussurea species from the eastern Tibetan plateau. Journal of Northwest Normal University (Natural Science), 44, 95-98. (in Chinese with English abstract) [李淮, 王转莉, 巩红冬, 王一峰 (2008) 青藏高原东缘 2 种风毛菊属植物的核型研究. 西北师范大学学报(自然科学版), 44, 95-98.]

Li JQ (1988) On the karyotypes in six species of Crotalaria L. in Yunnan. Journal of Wuhan Botanical Research, 6(1), 15-22. (in Chinese with English abstract) [李建强 (1988) 云南猪屎豆属 6 种植物的核型初报. 武汉 植物研究院, 6(1), 15-22.]

Li JQ, Wu ZY, Lu AM (1993) Cytological observation on the plants of Thladianthinae (Cucurbitaceae). Acta Botanica Yunnanica, 15, 101-104. (in Chinese with English abstract) [李建强, 吴征镒, 路安民 (1993) 葫 芦科赤爬亚族植物的细胞学观察. 云南植物研究, 15, 101-104.]

Li SF, Chang ZY (1996) A cytogeographical study on Clintonia udensis (Liliaceae). Acta Phytotaxonomica Sinica, 34, 29-38. (in Chinese with English abstract) [李思锋, 常朝阳 (1996) 七筋姑的细胞地理学研究. 植物分类学报, 34, 29-38.]

Li SJ, Li CH, He GY, Xu YC (2010) Analysis on chromosome karyotype of Kengyilia thoroldiana (Oliv.). Journal of Anhui Agricultural Sciences, 38, 3356-3357. (in Chinese with English abstract) [李淑娟，李长慧， 何国英，许永财 (2010) 梭罗草的染色体核型分析. 安徽农业科学, 38, 3356-3357.]

Li SZ, He TS, Zhang DC, Ding WQ (2013) Karyotypes of six species of genus Saussurea DC. in the Hengduan Mountains, southwestern China. Acta Botanica Boreali-Occidentalia Sinica, 33, 2194-2202. (in Chinese with 
王家坚, 彭智邦, 孙航, 聂泽龙, 孟盈. 青藏高原与横断山被子植物区系演化的细胞地理学特征. 生物多样 性, 2017, 25 (2): 218-225.

http://www.biodiversity-science.net/CN/10.17520/biods.2016281

English abstract) [李双智, 何廷顺, 张大才, 丁文谦 (2013) 风毛菊属 6 种植物的核型分析. 西北植物学 报, 33, 2194-2202.]

Li WJ, Liu JH, Li YP, Liu F (1996) Production and cytogenetic analysis of intergeneric hybrids between Elymus anthosachnoides and Psathyrostachys huashanica (Poaceae: Triticeae). Plant Systematics and Evolution, 202, 265-269.

Li X (2014) Classification of three species of Saussurea DC. in the Tibet Plateau. Master Thesis, Northwest Normal University. (in Chinese with English abstract) [李霞 (2014) 青藏高原三种风毛菊属植物的系统分 类研究. 硕士学位论文, 西北师范大学.]

Li YG, Guo WH, Wu BJ (2003) A karyological study of six Chinese species of Cymbidium. Acta Botanica Yunnanica, 25(1), 83-89. (in Chinese with English abstract) [李玉阁, 郭卫红, 吴伯骥 (2003) 六种国产兰 属植物的核型研究. 云南植物研究, 25(1), 83-89.]

Li ZM, He WJ (2007) Chromosome number and karyotype of Silene gracilicaulis (Caryophyllaceae) from Hengduan Mountains. Acta Botanica Yunnanica, 29, 439-440. (in Chinese with English abstract) [李志敏, 何文洁 (2007) 横断山区石竹科细蝇子草的染色体数目及核型报道. 云南植物研究, 29, 439-440.]

Li Z, Wang ZX, Geng SJ, Chen SM, Li WP (2015) A karyotypic study on three Aster species (Asteraceae). Acta Botanica Boreali-Occidentalia Sinica, 35, 1148-1152. (in Chinese with English abstract) [李志, 王梓辛, 耿 胜娟，陈三茂, 黎维平 (2015) 菊科紫苑属 3 种植物的核型分析. 西北植物学报, 35, 1148-1152.]

Liu HM, Zhi L, Zhao LH, Sui SZ, Li MY (2010) Karyotype analysis of four wild Lilium species. Journal of Plant Genetic Resources, 11, 469-473. (in Chinese with English abstract) [刘华敏, 智丽, 赵丽华, 眭顺照, 李名 扬 (2010) 四种野生百合核型分析. 植物遗传资源学报, 11, 469-473.]

Liu JL, Tang Y, Shao JR, Luo Q, Sun JX (2009) Karyotypic studies of two wild Buckwheat species in the Fagopyrum mill. Acta Botanica Boreali-Occidentalia Sinica, 29, 1798-1803. (in Chinese with English abstract) [刘建林, 唐宇, 郡继荣, 罗强, 孙俊秀 (2009) 菾麦属 2 个野生养麦种的染色体核型研究. 西 北植物学报, 29, 1798-1803.]

Liu JQ (2000) Karyomorphology of 4 species in Sinacalia and Parasenecio (Asteraceae: Senecioneae). Acta Botanica Yunnanica, 22, 447-450. (in Chinese with English abstract) [刘建全 (2000) 华蟹甲草属和蟹甲草 属 4 种植物的核型. 云南植物研究, 22, 447-450.]

Liu JQ, He TN (1999) Karyotypes of seven species of Delphinium from southern Qinghai. Acta Botanica Yunnanica, 21, 471-476. (in Chinese with English abstract) [刘建全, 何廷农 (1999) 青海南部七种翠雀属 植物的核型. 云南植物研究, 21, 471-476.]

Liu JQ, He TN, Chen SL (2002) Contributions to the karyomorphological data and taxonomic implications of Sect. Kudoa and Sect. Monopodiae in Gentianal. Acta Biologica Plateau Sinica, 15, 25-32. (in Chinese with English abstract) [刘建全，何廷农，陈世龙 (2002) 龙胆属华丽组和多枝组的核型资料及其分类学意义. 高原生物学集刊, 15, 25-32. ]

Liu JQ, He TN, Chen SL (2002) The chromosome number of 5 species in Gentianaceae. Acta Biologica Plateau Sinica, 15, 49-52. (in Chinese with English abstract) [刘建全，何廷农，陈世龙 (2002) 五种龙胆科植物的 染色体数目. 高原生物学集刊, 15, 49-52.]

Liu JQ, He TN, Chen SL (2002) The first chromosome data documentions of Megacodon and Lomatogoniopsis and the systematic significance (Gentianaceae). Acta Biologica Plateau Sinica, 15, 41-47. (in Chinese with English abstract) [刘建全, 何廷农, 陈世龙 (2002) 大钟花属和辐花属染色体资料的首次记载及其系统 学意义. 高原生物学集刊, 15, 41-47.]

Liu JQ, He TN, Liu SW (2000) Systematic position of Nannoglottis Maxim. s. l. (Asteraceae) karyomorphological data. Acta Phytotaxonomica Sinica, 38, 236-241. (in Chinese with English abstract) [刘 建全，何廷农，刘尚武 (2000) 毛冠菊属系统位置的核形态证据. 植物分类学报, 38, 236-241.] 
王家坚, 彭智邦, 孙航, 聂泽龙, 孟盈. 青藏高原与横断山被子植物区系演化的细胞地理学特征. 生物多样 性, 2017, 25 (2): 218-225.

http://www.biodiversity-science.net/CN/10.17520/biods.2016281

Liu JQ (1999) Karomorphological characteristics of three Aster species from southern Qinghai. Bulletin of Botanical Research, 19, 392-396. (in Chinese with English abstract) [刘建全 (1999) 青海南部三种紫苑属 植物的核型研究. 植物研究, 19, 392-396.]

Liu JQ (2002) Karyomorphological comparision on Aconitum tanguticum and A. gymnandrum from different altitudes. Acta Biologica Plateau Sinica, 15, 33-36. (in Chinese with English abstract) [刘建全 (2002) 关于 来自不同海拔的露芯乌头和甘青乌头的核型比. 高原生物学集刊, 15, 33-36.]

Liu JQ, Liu SW, He TN, Lu AM (2001) Karyological studies on the Sino-Himalayan genus, Cremanthodium (Asteraceae: Senecioneae). Botanical Journal of the Linnean Society, 135, 107-112.

Liu JQ (2004) Uniformity of karyotypes in Ligularia (Asteraceae: Senecioneae), a highly diversified genus of the eastern Qinghai-Tibet Plateau highlands and adjacent areas. Botanical Journal of the Linnean Society, 144, 329-342.

Liu RR (2010) The karyotype of the genus Rheumatum in the Tibetan Plateau and its adjacent areas. Master Thesis, Lanzhou University. (in Chinese with English abstract) [刘瑞瑞 (2010) 青藏高原及其邻近地区物 种丰富属一大黄属的核型研究. 硕士学位论文, 兰州大学.]

Liu YH (1985) Karyomorphology comparision of 11 species of Elymus in China. Journal of Wuhan Botanical Research, 40, 215-221. (in Chinese with English abstract) [刘玉红 (1985) 我国 11 种披碱草的核型研究. 武汉植物研究, 40, 215-221.]

Liu YH, Meng Y, Yang YH, Yang YP (2011) Chromosome numbers and karyotypes of six Oxytropis species (Fabaceae) from the Tibetan Plateau, China. Plant Diversity and Resources, 33, 423-431. (in Chinese with English abstract) [刘亚辉, 孟盈, 杨永红, 杨永平 (2011) 青藏高原六种棘豆属植物的染色体数目及核 型报道. 植物分类与资源学报, 33, 423-431.]

Liu YH, Wang SM (1994) Karyotype study of Astragalus polycladous. Acta Agrestia Sinica, 2(1), 56-58. (in Chinese with English abstract) [刘玉红，王善敏 (1994) 多枝黄芪的核型研究. 草地学报, 2(1), 56-58.]

Long CL, Li H, Liu XZ, Gu ZJ (1989) A cytogegraphic study on the genus Remusatia (Araceae). Acta Botanica Yunnanica, 11, 132-138. (in Chinese with English abstract) [龙春林, 李恒, 刘宪章, 顾志健 (1989) 天南 星科岩芋属的细胞地理学研究. 云南植物研究, 11, 132-138.]

Lu BR, Yan J, Yang JL (1990) Cytological observation of Triticeae Dumort in Xinjiang, Qinghai and Sichuan. Acta Botanica Yunnanica, 12, 57-66. (in Chinese with English abstract) [卢宝荣, 颜济, 杨俊良 (1990) 新 疆、青海和四川等地区小麦族植物的细胞学观察. 云南植物研究, 12, 57-66.]

Lu QY, Chen GF, Li ZM (2010) Cytology research on Saussurea tatsienensis Franch (Saussurea). Journal of Yunnan Normal University (Natural Science edition), 30(6), 58-61. (in Chinese with English abstract) [陆覃 昱, 陈光富, 李志敏 (2010) 风毛菊属打箭风毛菊(Saussurea tatsienensis Franch.)的细胞学研究. 云南师 范大学学报(自然科学版), 30(6), 58-61.]

Lu XF, He TN, Liu JQ (2002) Sinadoxa is the most evolved in the muskroot family groups. Acta Biologica Plateau Sinica, 15, 105-112. (in Chinese with English abstract) [卢学峰, 何廷农, 刘建全 (2002) 华福花 属是五福花科中最进化的类群吗. 高原生物学集刊, 15, 105-112.]

Lu YX, Sun XF, Zhou QX, Gu ZJ (2002) Chromosome numbers in ten species in the Gesneriaceae from Yunnan. Acta Botanica Yunnanica, 24, 377-382. (in Chinese with English abstract) [鲁元学, 孙先风, 周其兴, 顾志 健 (2002) 云南十种苦菅苔科植物的染色体数目报道. 云南植物研究, 24, 377-382.]

Luo D, Liu D, Xu B, Nie ZL, Sun H, Li ZM (2011) A karyological study of six species of Silene L. (Caryophyllaceae) from the Hengduan Mountains, SW China. Caryologia, 64(1), 10-13.

Luo YB (2004) Cytological studies on some representative species of the tribe Orchideae (Orchidaceae) from China. Botanical Journal of the Linnean Society, 145, 231-238.

Luo YX, Yue XK, Sun H, Li ZM (2008) Cytological studies on Arenaria roborowskii (Caryophyllaceae) from 
王家坚, 彭智邦, 孙航, 聂泽龙, 孟盈. 青藏高原与横断山被子植物区系演化的细胞地理学特征. 生物多样 性, 2017, 25 (2): 218-225.

http://www.biodiversity-science.net/CN/10.17520/biods.2016281

Hengduan Mountains. Acta Botanica Yunnanica, 30, 662-664. (in Chinese with English abstract) [罗元霞, 岳学坤, 孙航, 李志敏 (2008) 横断山脉地区青藏雪灵芝核形态学. 云南植物研究, 30, 662-664.]

Ma SB, Hu ZH (1996) A karyotypic study on Podophylloideae (Berberidaceae). Acta Botanica Yunnanica, 18, 325-330. (in Chinese with English abstract) [马绍宾, 胡志浩 (1996) 小璧科鬼臼亚科植物的核型研究. 云南植物研究, 18, 325-330.]

Meng Y, Nie ZL, Sun H, Yang YP (2010) Chromosome numbers and polyploidy in Leontopodium (Asteraceae: Gnaphalieae) from the Qinghai-Tibet Plateau of SW China. Caryologia, 65(2), 87-93.

Meng Y, Nie ZL, Xie HY, Yang YP (2006) A karyomorphological study on four species of Meconopsis Vig. (Papaveraceae) from the Hengduan Mountains, SW China. Caryologia, 59, 1-6.

Meng Y, Nie ZL, Yang YP, Gu ZJ (2005) Karyomorphology of Maianthemum sensu lato (Polygonatae, Ruscaceae). Journal of Plant Research, 118, 155-162.

Meng Y, Sun H, Yang YP, Nie ZL (2010) Polyploidy and new chromosome counts in Anaphalis (Asteraceae: Gnaphalieae) from the Qinghai-Tibet Plateau of China. Journal of Systematics and Evolution, 48, 58-64.

Meng Y, Yang YP, Sun H, Deng T, Nie ZL (2014) Chromosome numbers karyotypes and polyploidy evolution of Anaphalis species (Asteraceae: Gnaphalieae) from the Hengduan Mountains, SW China. Caryologia, 67, 238-249.

Mu YL, Xi RT, Lü ZR (1990) Microsporogenesis observation and karyotype analysis of some species in genus Juglans L. Journal of Wuhan Botanical Research, 8, 301-310. (in Chinese with English abstract) [穆英林, 郗荣庭, 吕增仁 (1990) 核桃属部分种的小孢子发生及核型研究. 武汉植物研究院, 8, 301-310.]

Masashi N, Wu QA, Syo K (1997) Cytological studies on Chinese plants introduced from Yunnan Province. I. Karyomorphology of some species of Primula and Androsace (Primulaceae). Bull. Bot. Gard. Toyama, 2, $1-15$.

Nie ZL (2002) A preliminarily cytogeographical study on the angiosperm flora in the Hengduan, China—with cytogeographical study of genus Tibetia. Master thesis, Kunming Institute of Botany, Kunming. (in Chinese with English abstract) [聂泽龙 (2002) 横断山区被子植物区系细胞地理学初探——兼论高山豆属细胞 地理学研究. 硕士学位论文, 中国科学院昆明植物研究所, 昆明.]

Nie ZL, Gu ZJ, Sun H (2002) Cytological study of Tibetia (Fabaceae) in the Hengduan Mountains region, China. Journal of Plant Research, 115(1), 17-22.

Pan YZ, Gong X, Yang ZY, Yin Q (2004) Karyological studies on five species of the genus Ligularia (Compositae: Senecioneae). Acta Botanica Yunnanica, 26, 65-72. (in Chinese with English abstract) [潘跃芝, 龚洵, 杨志云, 尹擎 (2004) 五种橐吾属植物的核型研究. 云南植物研究, 26, 65-72.]

Pan ZH, Chin HC, Wu ZJ, Yuan CQ, Liu SL (1985) A report on the chromosome numbers of Chinese Umbelliferae. Acta Phytotaxonomica Sinica, 23, 97-102. (in Chinese with English abstract) [潘泽惠, 秦慧 贞, 吴竹君, 袁昌齐, 刘守炉 (1985) 伞形科植物染色体数目报告. 植物分类学报, 23, 97-102.]

Pan ZH, Liu XT, She ML, Xu LR (1991) A study on karyotypes of eight species and geographical distribution of Angelica (Umbelliferae) in Sichuan. Acta Phytotaxonomica Sinica, 29, 431-438. (in Chinese with English abstract) [潘泽惠, 刘心恬, 余孟兰, 徐朗然 (1991) 四川当归属八种植物的核型及地理分布研究. 植物 分类学报, 29, 431-438.]

Pei J, Ding ZZ, Chin HC, Su P, Tang SY, Zhang HQ (1979) A preliminary systematic study of Dioscorea L. sect. Stenophora Uline. Acta Phytotaxonomica Sinica, 17, 61-72. (in Chinese with English abstract) [裴鉴, 丁志 遵, 秦慧贞, 舒璞, 唐世蓉, 张涵庆 (1979) 中国薯蓣属根状茎组系统分类的初步研究. 植物分类学报, 17, 61-72.]

Peng YL, Sun H, Gu ZJ (2002) Cytological study on Nouelia and Leucomeris Compositae. Acta Botanica Yunnanica, 24, 82-86. (in Chinese with English abstract) [彭玉兰，孙航，顾志建 (2002) 栌菊木属及白菊 
王家坚, 彭智邦, 孙航, 聂泽龙, 孟盈. 青藏高原与横断山被子植物区系演化的细胞地理学特征. 生物多样 性, 2017, 25 (2): 218-225.

http://www.biodiversity-science.net/CN/10.17520/biods.2016281

木属的细胞学研究. 云南植物研究, 24, 82-86.]

Pi J, Zhou SD, He XJ, Tang ZH, Wang Q (2008) Karyotypes of six populations of four species in the genus Mallotus (Euphorbiaceae) from China. Acta Botanica Boreali-Occidentalia Sinica, 28, 256-261. (in Chinese with English abstract) [ 皮军，周颂东，何兴金，唐自慧，王强 (2008) 大戟科野桐属 4 种 6 个居群的核型 研究. 西北植物学报, 28, 256-261.]

Pu JX, He XJ, Zhang XM, Chen WW (2006) Karyotypes of Umbelliferae of four species in seven populations in Hengduan Mountains. Acta Botanica Boreali-Occidentalia Sinica, 26, 1989-1995. (in Chinese with English abstract) [蒲吉霞, 何兴金, 张雪梅, 陈薇薇 (2006) 横断山区伞形科 4 种 7 个居群植物的核型研究. 西 北植物学报, 26, 1989-1995.]

Qian M, Wang GY, Meng Y, Yang YP (2015) Karyotypes and C-values of two Plantago species from the Qinghai-Tibet Plateau, China. Plant Diversity and Resources, 37, 407-415. (in Chinese with English abstract) [钱敏, 王广艳, 孟盈, 杨永平 (2015) 青藏高原二种车前属植物的核型和 C-值报道. 植物分类与资源 学报, 37, 407-415.]

Qing QJ (2011) Karyotypes and genetic variations in 9 species of Lilium. Master thesis, Sichuan Agricultural University. (in Chinese with English abstract) [卿秋静 (2011) 九种百合属植物核型及遗传变异研究. 硕 士学位论文, 四川农业大学.]

Ren BQ, Liu J (2006) Cytological study on Alnus in China. Guihaia, 26, 356-359. (in Chinese with English abstract) [任保青, 刘军 (2006) 中国桤木属植物的细胞学研究. 广西植物, 26, 356-359.]

Russell A, Safer S, Weiss-Schneeweiss H, Temsch E, Stuppner H, Stuessy TF, Samuel R (2013) Chromosome counts and genome size of Leontopodium species (Asteraceae: Gnaphalieae) from south-western China. Botanical Journal of the Linnean Society, 171, 627-636.

Seavey SR, Boufford DE (1983) Observations of chromosomes in Circaea (Onagraceae). American Journal of Botany, 70, 1476-1481.

Shang BL, Meng KB, Wang YJ (2014) Karyotype analysis of five Saussurea species. Acta Botanica Boreali-Occidentalia Sinica, 34, 2220-2226. (in Chinese with English abstract) [尚宝龙，蒙奎宾，王玉金 (2014) 风毛菊属 5 种植物的核型分析. 西北植物学报, 34, 2220-2226.]

Shang XM, Li ZL (1984) Chromosome studies of 10 species of Aconitum in China. Acta Phytotaxonomica Sinica, 22, 378-385. (in Chinese with English abstract) [商效民，李正理 (1984) 国产十种乌头的染色体研究. 植 物分类学报, 22, 378-385.]

Shang XM (1985) Chromosome studies of subgenus Gymnaconitum endemic to China and Beesia (Ranunculaceae). Acta Phytotaxonomica Sinica, 23, 270-274. (in Chinese with English abstract) [商效民 (1985) 中国特有的露荵乌头亚属及铁破锣的染色体研究. 植物分类学报, 23, 270-274.]

Shao JR, Zhou ML, Zhu XM, Wang DZ, Bai DQ (2011) Fagopyrum wenchuanense and Fagopyrum qiangcai, two new species of Polygonaceae from Sichuan, China. Novon, 21, 256-261.

Shen YG, Wang ZL, Guan KY (2007) Karyotypical studies on thirteen Iris plants from China. Acta Phytotaxonomica Sinica, 45, 601-618. (in Chinese with English abstract) [沈云光, 王仲朗, 管开云 (2007) 国产 13 种感尾属植物的核型研究. 植物分类学报, 45, 601-618.]

Soltis DE, Bohm BA (1984) Karyology and flavonoid chemistry of the disjunct species of Tiarella (Saxifragaceae). Systematic Botany, 9, 441-447.

Stergianou KK (1989) Habit differentiation and chromosome evolution in Pleione (Orchidaceae). Plant Systematics and Evolution, 166, 253-264.

Sun GL, Liu F, Yen C, Yang JL (1992) Biosystematic study between Roegneria hondai and R. ciliaris of the tribe Triticeae. Guihaia, 12, 222-228.

Sun GL, Yang JL, Yan J (1993) A biosystematics study on hybrids between Psathyrostachys huashanica and two 
王家坚, 彭智邦, 孙航, 聂泽龙, 孟盈. 青藏高原与横断山被子植物区系演化的细胞地理学特征. 生物多样 性, 2017, 25 (2): 218-225.

http://www.biodiversity-science.net/CN/10.17520/biods.2016281

species of Roegneria. Acta Phytotaxonomica Sinica, 31, 393-398. (in Chinese with English abstract) [孙根楼, 杨俊良, 颜济 (1993) 华山新麦草和我观草属两个种间物种生物学研究. 植物分类学报, 31, 393-398.]

Sun GL, Yan J, Yang JL (1993) Studies on karyotypes of two species in Kengyilia and three species in Roegneria. Acta Phytotaxonomica Sinica, 31, 560-564. (in Chinese with English abstract) [孙根楼, 颜济, 杨俊良 (1993) 仲涁草属和我观草属几个种的核型研究. 植物分类学报, 31, 560-564.]

Tamura MN, Ogisu M, Xu JM (1997) Heteropolygonatum, a new genus of the tribe Polygonateae (Convallariaceae) from west China. Kew Bulletin, 52, 949-956.

Tang YC, Xiang QY, Cao YL (1984) Cytological studies on some plants of Sichuan and neighbouring regions (1). Acta Phytotaxonomica Sinica, 22, 343-350. (in Chinese with English abstract) [汤彦承，向秋云，曹亚玲 (1984) 四川及其邻近地区一些植物的细胞学研究(一). 植物分类学报, 22, 343-350.]

Tang ZH, Gao YD, Zhou SD, He XJ (2009) Karyotypes of fifteen populations of four species in Maianthemum (Liliaceae) from Southwestern China. Acta Botanica Yunnanica, 31, 1-7. (in Chinese with English abstract) [唐自慧, 高云东, 周颂东, 何兴金 (2009) 中国西南地区鹿药属 4 种 15 居群核型研究. 云南植物研究, 31, 1-7.]

Tian DK, Guan KY, Zhou QX, Gu ZJ (2002) Chromosome numbers of eight species of Begonia from Yunnan. Acta Botanica Yunnanica, 24, 245-249. (in Chinese with English abstract) [田代科，管开云，周其兴，顾志 建 (2002) 云南八种秋海棠属植物的染色体数目. 云南植物研究, 24, 245-249.]

Tsuneo F, Katsuhiko K, Hong DY, Zhou SL, Hisakazu O (2000) A comparative chromosomal study of five species of Chrysosplenium collected in the northern part of Sichuan Province, China. Chromosome Science, 4, 69-74.

Tsuneo F, Katsuhiko K, Hong DY, Zhou SL, Hironori D, Hisakazu O (2000) A cytological observation of Rodgersia aesculifolia Batalin (Saxifragaceae) collected in Shaanxi and Sichuan provinces, China. Chromosome Science, 4, 65-68.

Tsuneo F, Katsuhiko K, Hong DY, Zhou SL, Hisakazu O (2001) Chromosomes in four species of Parnassia (Saxifragaceae) in the northern part of Sichuan Province, China. Chromosome Science, 5, 19-25.

Tsuneo F, Katsuhiko K, Hong DY, Zhou SL (1997) Karyomorphological studies in Parnassia yunnanensis var. longistipitata in Sichuan Province, China. Chromosome Science, 1, 21-24.

Tsuneo F, Katsuhiko K, Hong DY, Zhou SL, Takuko S (1997) Karyomorphology of Chrysosplenium griffithii collected in Sichuan Province, China. Chromosome Science, 1(2), 61-64.

Tsuneo F, Katsuhiko K, Hong DY, Zhou SL, Takuko S (1998) A karyomorphological comparison of four Saxifraga species collected in the western part of Sichuan Province, China. Chromosome Science, 2, 103-109.

Tsuneo F, Rie S, Katsuhiko K, Hong DY, Zhou SL, Hisakazu O (2001) Comparative karyomorphology of five species of Saxifraga in northern part of Sichuan Province, China. Chromosome Science, 5, 27-34.

Tu TY, Sun H, Gu ZJ, Yue JP (2005) Cytological studies on the Sino-Himalayan endemic Anisodus and four related genera from the tribe Hyoscyameae (Solanaceae), and their systematic and evolutionary implications. Botanical Journal of the Linnean Society, 147, 457-468.

Tu TY, Sun H, Bartholomew B, Nie ZL (2006) Cytological study on Kelloggia (Rubiaceae), an intercontinental disjunct genus between eastern Asia and western North America. Journal of Plant Research, 119, 397-400.

Tuo ZY, Abulaity H, Zhou GL (2012) A report on chromosome numbers and karyotypes of 12 species of Brassicaceae from Xinjiang. Journal of Xinjiang Agricultural University, 35, 439-445. (in Chinese with English abstract) [芦忠云, 阿不来提·哈德尔, 周桂玲 (2012) 新疆 12 种十字花科植物核型报道. 新疆农 业大学学报, 35, 439-445.]

Wan J, Zhou SD, Gao YD, He XJ (2011) Karyotypes of twenty-five populations of thirteen species in 
王家坚, 彭智邦, 孙航, 聂泽龙, 孟盈. 青藏高原与横断山被子植物区系演化的细胞地理学特征. 生物多样 性, 2017, 25 (2): 218-225.

http://www.biodiversity-science.net/CN/10.17520/biods.2016281

Nomocharis and Lilium. Plant Diversity and Resources, 33, 477-494. (in Chinese with English abstract) [万 娟, 周颂东, 高云东, 何兴金 (2011) 豹子花属及百合属 13 种 25 居群的核型研究. 植物分类与资源学 报, 33, 477-494.]

Wang GY, Meng Y, Nie ZL, Yang YP (2013) Karyotypes of five Leontopodium species from the Southeastern Qinghai-Tibet Plateau. Plant Diversity and Resources, 35, 355-360. (in Chinese with English abstract) [王广 艳，孟盈，聂泽龙，杨永平 (2013) 青藏高原东南缘五种火线草属植物的核型. 植物分类与资源学报, 35, 355-360.]

Wang HX, Zhang YF, Yang BS (2006) Comparative analysis on variation patterns of karyotype in Lilium. Journal of Henan Institute of Science and Technology, 34(4), 38-40. (in Chinese with English abstract) [王红霞, 张 艳芬，杨保胜 (2006) 百合属植物核型变异式样对比分析. 河南科技学院学报: 自然科学版, 34(4), 38-40.]

Wang H, Li WL, Gu ZJ, Chen YY (2001) Cytological study on Acorus L. in southwestern China, with some cytogeographical notes on A. calamus. Acta Botanica Sinica, 43, 354-358. (in Chinese with English abstract) [王红, 李文丽, 顾志建, 陈永燕 (2001) 中国西南部菖蒲属的细胞学研究, 兼论菖蒲的细胞地理. 植物 学报, 43, 354-358.]

Wang JW, Yang J, Li MX (1993) The morphological variation and the karyotypical characters of Dendranthema indicum and D. lavandulifolium. Acta Phytotaxonomica Sinica, 31, 140-146. (in Chinese with English abstract) [汪劲武，杨继，李惁学 (1993) 野菊和甘菊的形态变异及其核型特征. 植物分类学报，31, 140-146.]

Wang KQ, Ge S (1998) A karyotype study on five species of Adenophora. Acta Botanica Yunnanica, 20, 58-62. (in Chinese with English abstract) [王可青, 葛颂 (1998) 国产沙参属五个种的核型研究. 云南植物研究, 20, 58-62.]

Wang L, Gu ZJ, Sun H (1994) Preliminary karyomorphological study on the plants in genera Oxytropis and Astragalus from Tibetan Plateau. Acta Botanica Yunnanica, 16, 53-59. (in Chinese with English abstract) [王 丽, 顾志建, 孙航 (1994) 青藏高原几种黄芪和棘豆植物核型的初步研究. 云南植物研究, 16, 53-59.]

Wang L, Gu ZJ, Gong X, Xiao TJ (1993) A cytological study on fifteen species in six genera of Liliaceae from Yunnan. Acta Phytotaxonomica Sinica, 31, 549-559. (in Chinese with English abstract) [王丽, 顾志建, 龚 洵，肖调江 (1993) 百合科六属十五种植物的细胞学研究. 植物分类学报, 31, 549-559.]

Wang L, Gu ZJ, Sun H (1994) Preliminary karyomorphological study on the plants in genera Oxytropis and Astragalus from Qinghai-Xizang Plateau. Acta Botanica Yunnanica, 16, 53-59. (in Chinese with English abstract) [王丽, 顾志建, 孙航 (1994) 青藏高原几种黄芪和棘豆植物核型的初步研究. 云南植物研究, 16, 53-59.]

Wang LQ, Yang P, Nie XX, Gao Y, Lu T (2013) Chromosome karyotype of N. micrantha Bunge. Chinese Horticul Ture Abstracts, (8), 52-54. (in Chinese with English abstract) [王立群, 杨平, 聂晓霞, 高燕, 陆婷 (2013) 小花荆芥(N. micrantha Bunge)染色体的核型分析. 中国园艺文摘, (8), 52-54.]

Wang SF (1989) Karyotype uniformity of Paris and Trillium tschonoskii. Acta Botanica Yunnanica, 11, 75-79. (in Chinese with English abstract) [王淑芬 (1989) 重楼属和延龄草核型的一致性. 云南植物研究, 11, 75-79.]

Wang SF, Song TY (1994) A karyotypes report of four Fritillaria. Journal of Sichuan Normal University (Natural Science), 17(6), 93-99. (in Chinese with English abstract) [王淑芬, 宋天瑛 (1994) 贝母属 4 种核型的报 道. 四川师范大学学报(自然科学版), 17(6), 93-99.]

Wang SF, Xu JM (1989) Cytotaxonomical studies on Liliaceae-Karyotypes of taxa of 2 genera. In: Plant Chromosome Research (ed. Hong DY), pp. 337-341. Nishiki, Hiroshima.

Wang XR, Tang HR, Fu HQ, Luo Y, Deng QX, Dong XL, Li L, Duan J (2008) Chromosome numbers and 
王家坚, 彭智邦, 孙航, 聂泽龙, 孟盈. 青藏高原与横断山被子植物区系演化的细胞地理学特征. 生物多样 性, 2017, 25 (2): 218-225.

http://www.biodiversity-science.net/CN/10.17520/biods.2016281

karyotypes of 10 species wild Bramble (Rubus L.) from Southwest of China. Acta Horticulturae Sinica, 35, 343-350. (in Chinese with English abstract) [王小蓉, 汤浩茹, 付华清, 罗娅, 邓群仙, 董晓莉, 李玲, 段 娟 (2008) 西南地区 10 种野生树莓的染色体数与核型研究. 园艺学报, 35, 343-350.]

Wang YF, Gong HD, Gao SF, Liang WF (2006) Karyotype study of five species of Saussurea in the eastern of Tibet Plateau. Journal of Sichuan University(Natural Science), 43, 1132-1136. (in Chinese with English abstract) [王一峰, 巩红冬, 高素芳, 梁万福 (2006) 青藏高原东缘五种风毛菊属植物的核型研究. 四川 大学学报(自然科学版), 43, 1132-1136.]

Wang YF, Gao SF, Gong HD, Liu J (2007) On karyotypes of four species of Saussurea DC. in the east of Qinghai -Tibet Plateau. Journal of Northwest A and F University (Natural Science Edition), 35, 199-203. (in Chinese with English abstract) [王一峰, 高素芳, 巩红冬, 刘静 (2007) 青藏高原东缘高寒草甸风毛菊属 4 个优 势种的核型研究. 西北农林科技大学学报(自然科学版), 35, 199-203.]

Wang YF, Sha J, Wang ZL, Zhou SH, Yang ZB (2010) A report on karyotypes of two Saussurea species from the eastern Qinghai-Tibetan Plateau. Journal of Northwest Normal University (Natural Science), 46, 75-78. (in Chinese with English abstract) [王一峰, 沙洁, 王转莉, 周生荟, 杨宗邦 (2010) 青藏高原东缘风毛菊属 中两种植物的核型报道. 西北师范大学学报(自然科学版), 46, 75-78.]

Wang YF, Wang ZL, Gong HD, Guo HQ, Liang WF, Pang HL (2008) Karyotypic studies on 5 species of Subgen. Amphilaena and Subgen. Saussurea in Saussurea from the Qinghai-Tibetan Plateau. Journal of Sichuan University(Natural Science), 45, 1221-1227. (in Chinese with English abstract) [王一峰, 王转莉, 巩红冬, 郭怀青, 梁万福, 庞海龙 (2008) 青藏高原风毛菊属中雪莲亚属和风毛菊亚属的五种植物的核型研究. 四川大学学报(自然科学版), 45, 1221-1227.]

Wang YF, Wang ZL, Gong HD, Guo HQ, Liang WF (2008) Study on karyotypes of 4 species of Saussures DC. in the east of Qinghai-Tibetan Plateau. Journal of Northwest A and F University(Natural Science edition), 36, 165-170. (in Chinese with English abstract) [王一峰, 王转莉, 巩红冬, 郭怀清, 梁万福 (2008) 青藏高原 东缘 4 种风毛菊属植物的核型研究. 西北农林科技大学学报(自然科学版), 36, 165-170.]

Wang YZ, Gu ZJ (1999) Karyomorphology of four species in Ancylostemon, Briggsiopsis and Lysionotus (Gesneriaceae). Acta Phytotaxonomica Sinica, 37, 137-142. (in Chinese with English abstract) [王印政, 顾 志建 (1999) 直瓣菅苔属、筒花菅苔属和吊石菅苔属 4 个种的核形态学研究. 植物分类学报, 37, 137-142.]

Xia LF, Gu ZJ, Wang ZL, Xiao TJ, Wang L, Katsuhiko K (1994) Dawn on the origin of Camellia reticulata-The new discovery of its wild diploid in Jinshajiang valley. Acta Botanica Yunnanica, 16, 255-262. (in Chinese with English abstract) [夏丽芳, 顾志建，王仲朗，肖调江，王丽，近藤胜彦 (1994) 探讨云南山茶起源的 一线曙光一一野生二倍体类型在金沙江流域的发现. 云南植物研究, 16, 255-262.]

Xiao TJ, Gu ZJ, Xia LF (1993) A study on meiosis of 9 species in genus Camellia. Acta Botanica Yunnanica, 15, 167-172. (in Chinese with English abstract) [肖调江, 顾志建, 夏丽芳 (1993) 九种山茶属植物的减数分 裂研究. 云南植物研究, 15, 167-172.]

Xiao TJ, Xia LF, Wang ZL (1996) Studies on the giemsa C-bands of Camellia species, section Camellia from the middle reach of Jinshajiang Valley. Acta Botanica Yunnanica, 18, 81-86. (in Chinese with English abstract) [肖调江, 夏丽芳, 王仲朗 (1996) 金沙江中游地区红山茶组植物的 Giemsa C一带研究. 云南植物研究, 18, 81-86.]

Xiao H, Zhou QX, Gu ZJ, Guan KY (2002) Karyomorphology of six Incarvillea species. Acta Botanica Yunnanica, 24, 87-93. (in Chinese with English abstract) [肖华, 周其兴, 顾志建，管开云 (2002) 角高属 6 个种的核形态学研究. 云南植物研究, 24, 87-93.]

Xie XY, Wu QA (1993) The determination of karyotype and isoesterase on triploid Lilium davidii. Acta Botanica Yunnanica, 15, 57-60. (in Chinese with English abstract) [谢晓阳, 武全安 (1993) 三倍体川百合的核型与 
王家坚, 彭智邦, 孙航, 聂泽龙, 孟盈. 青藏高原与横断山被子植物区系演化的细胞地理学特征. 生物多样 性, 2017, 25 (2): 218-225.

http://www.biodiversity-science.net/CN/10.17520/biods.2016281

酯酶同功酶鉴定. 云南植物研究, 15, 57-60.]

Xie XY, Gu ZJ, Wu QA (1992) Cytological studies of the genus Nomocharis and its related genera. Acta Phytotaxonomica Sinica, 30, 487-497. (in Chinese with English abstract) [谢晓阳，顾志健，武全安 (1992) 豹子花属及其近缘属细胞学研究. 植物分类学报, 30, 487-497.]

Xiong ZT, Chen XQ (1998) Numerical cytotaxonomic studies of Hemerocallis (Liliaceae) from China. Acta Phytotaxonomica Sinica, 36, 205-215. (in Chinese with English abstract) [熊治廷，陈心启 (1998) 中国萱 草属(百合科)的数量细胞分类研究. 植物分类学报, 36, 205-215.]

Yang DQ, Zhu XF (1989) Karyotypic studies of Paeonia obovata, P. delavayi and P. delavayi var. lutea. Acta Botanica Yunnanica, 11, 139-144. (in Chinese with English abstract) [杨涤清, 朱莶桴 (1989) 草苟药、野 牡丹和黄牡丹的核型研究. 云南植物研究, 11, 139-144.]

Yang J, Wang JW, Li MX (1992) Cytotaxonomic studies on the genus Polygonatum. III. Chromosome numbers and karyotypes of 6 species from China. Journal of Wuhan Botanical Research, 10, 201-206. (in Chinese with English abstract) [杨继, 汪劲武, 李森学 (1992) 黄精属细胞分类学研究. III. 国产 6 种黄精的染色 体数目和核型. 武汉植物学研究, 10, 201-206.]

Yang L, Xu JM, Zhang XL, Wang HQ (1998) Karyotypical studies of six species on the genus Allium. Acta Phytotaxonomica Sinica, 36, 36-46. (in Chinese with English abstract) [杨蕾, 许介眉, 张小亮, 万海清 (1998) 六种葱属植物核型研究. 植物分类学报, 36, 36-46.]

Yang QE (2000) A new species of Ranunculus from the northwest of Yunnan Province. Acta Phytotaxonomica Sinica, 38, 551-556. (in Chinese with English abstract) [杨亲二 (2000) 云南西北部毛茛属一新种一一文 采毛莨及其核型. 植物分类学报, 38, 551-556.]

Yang QE (1996) A karyotype study of 15 species in the tribe Delphineae (Ranunculaceae) from China. Acta Phytotaxonomica Sinica, 34, 39-47. (in Chinese with English abstract) [杨亲二 (1996) 国产十五种翠雀族 植物的核型研究. 植物分类学报, 34, 39-47.]

Yang QE (2001) Cytology of 12 species in Aconitum L. and 18 species in Delphinium L. from China. Acta Phytotaxonomica Sinica, 39, 502-514. (in Chinese with English abstract) [杨亲二 (2001) 国产 12 种乌头属 和 18 种翠雀属植物的细胞学研究. 植物分类学报, 39, 502-514.]

Yang QE (2001) Cytology of eleven species in the genus Ranunculus L. and five in its four related genera from China. Acta Phytotaxonomica Sinica, 39, 405-422. (in Chinese with English abstract) [杨亲二 (2001) 国产 毛莨属 11 种及其 4 个近缘属 5 种植物的细胞学研究. 植物分类学报, 39, 405-422.]

Yang QE (2002) Cytology of the tribe Trollieae and of the tribe Cimicifugeae in the Ranunculaceae: a comparative study. Acta Phytotaxonomica Sinica, 40, 453-460. (in Chinese with English abstract) [杨亲二 (2002) 毛莨科金莲花族和升麻族细胞学的比较研究. 植物分类学报, 40, 453-460. ]

Yang QE (2002) Cytology of ten species in Anemone, one in Anemoclema and six in Clematis (Trib. Anemoneae, Ranunculaceae) from China. Acta Phytotaxonomica Sinica, 40, 396-405. (in Chinese with English abstract) [杨亲二 (2002) 国产毛茛科银莲花族十七种植物的细胞学研究. 植物分类学报, 40, 396-405.]

Yang QE (1998) Does Actaea asiatica have the most symmetric and primitive karyotype in the Ranunculaceae? Acta Phytotaxonomica Sinica, 36, 490-495. (in Chinese with English abstract) [杨亲二 (1998) 类叶升麻具 有毛莨科中最对称和最原始的核型吗? 植物分类学报, 36, 490-495.]

Yang QE, Gong X (1995) A new species of the genus Aconitum L. from Yunnan, with an observation on its $B$ chromosomes. Acta Phytotaxonomica Sinica, 33, 572-575. (in Chinese with English abstract) [杨亲二, 龚洵 (1995) 云南乌头属一新种及其 B 染色体的初步观察. 植物分类学报, 33, 572-575.]

Yang QE, Gong X, Gu ZJ, Wu QA (1993) A karyomorphological study of five species in the Ranunculaceae from Yunnan, with a special consideration on systematic positions of Asteropyrum and Calathodes. Acta Botanica Yunnanica, 15, 179-190. (in Chinese with English abstract) [杨亲二, 龚洵, 顾志建, 武全安 (1993) 云南 
王家坚, 彭智邦, 孙航, 聂泽龙, 孟盈. 青藏高原与横断山被子植物区系演化的细胞地理学特征. 生物多样 性, 2017, 25 (2): 218-225.

http://www.biodiversity-science.net/CN/10.17520/biods.2016281

五种毛茛科植物的核形态研究兼论星果草属和鸡爪草属的系统位置. 云南植物研究, 15, 179-190.]

Yang QE, Gu ZJ, Sun H (1995) The karyotype of Beesia deltophylla and its systematic significance. Acta Phytotaxonomica Sinica, 32, 225-229. (in Chinese with English abstract) [杨亲二, 顾志建, 孙航 (1995) 角叶铁破锣的核型及其系统学意义. 植物分类学报, 32, 225-229.]

Yang QE, Gu ZJ, Wu ZY, Katsuhiko K (1989) A karyomorphological study of some Yunnan species of Aconitum L. (Ranunculaceae). Kromosomo II, 55-56, 1838-1860.

Yang QE, Gu ZJ, Wu ZY (1994) A karyomorphological study in Aconitum subgen. Lycoctonum (Ranunculaceae) from Yunnan. Acta Botanica Yunnanica, 16, 61-74. (in Chinese with English abstract) [杨亲二, 顾志建, 吴 征镒 (1994) 云南乌头属牛扁亚属的核形态研究. 云南植物研究, 16, 61-74.]

Yang QE, Gu ZJ, Wu ZY, Hong DY (1993) A karyomorphological study in Aconitum subgen. Aconitum (Ranunculaceae) from Yunnan, China. Cathaya, 5, 89-114.

Yang QE (1999) Karyomorphology of four species in Cimicifuga (Ranunculaceae) from China, with some cytogeographical notes on C. foetida. Acta Phytotaxonomica Sinica, 37, 433-444. (in Chinese with English abstract) [杨亲二 (1999) 国产毛茛科升麻属四种植物的核形态研究, 并略论升麻的细胞地理. 植物分 类学报, 37, 433-444.]

Yang QE (2000) Karyomorphology of the genus Oxygraphis Bunge (Ranunculaceae). Acta Phytotaxonomica Sinica, 38, 350-354. (in Chinese with English abstract) [杨亲二 (2000) 毛茛科鸭跖花属的核形态研究. 植物分类学报, 38, 350-354.]

Yang QE (1995) On the chromosomes of Calathodes (Ranunculaceae) and its systematic position. Acta Phytotaxonomica Sinica, 33, 453-460. (in Chinese with English abstract) [杨亲二 (1995) 鸡爪草属的染色 体及其系统位置. 植物分类学报, 33, 453-460.]

Yang QE (1999) The first discovery of diploid Beesia calthifolia and it's tetraploid cell type. Acta Phytotaxonomica Sinica, 37, 1-9. (in Chinese with English abstract) [杨亲二 (1999) 二倍体铁破锣的核型 及四倍体细胞型的首次发现. 植物分类学报, 37, 1-9.]

Yang X, Lu SG, Peng H (2008) Cytological studies on the eastern Asian family Trochodendraceae. Botanical Journal of the Linnean Society, 158, 332-335.

Yang Z, Gong X (2004) Cytological study of six Salvia species (lamiaceae) from the Hengduanshan Mountains region of China. Caryologia, 57, 360-366.

Yang ZY, Yi TS, Li H, Gong X (2003) A cytological study on three species of Colocasia (Araceae) from Yunnan. Caryologia, 56, 323-327.

Yuan Q, Yang QE (2008) Low incidence of polyploids and high uniformity of karyotypes displayed by Delphinium (Ranunculaceae) in the Hengduan Mountains Region of south-west China. Botanical Journal of the Linnean Society, 158, 172-188.

Yuan Q, Yang QE (2006) Polyploidy in Aconitum subgenus lycoctonum (Ranunculaceae). Botanical Journal of the Linnean Society, 150, 343-353.

Yuan YM, Küpfer P (2009) Karyological studies of Gentianopsis Ma and some related genera of Gentianaceae from China. Cytologia, 58, 115-123.

Yuan YM, Küpfer P (1997) The monophyly and rapid evolution of Gentiana sect. Chondrophyllae Bunge s.l. (Gentianaceae): evidence from the nucleotide sequences of the internal transcribed spacers of nuclear ribosomal DNA. Botanical Journal of the Linnean Society, 123, 25-43.

Yuan YM, Philippe K, Louis Z (1998) Chromosomal evolution of Gentiana and Jaeschkea (Gentianaceae), with further documentation of chromosome data for 35 species from western China. Plant Systematics and Evolution, 210, 231-247.

Yue JP, Gu ZJ, Al-Shehbaz I, Sun H (2004) Cytological studies on the Sino-Himalayan endemic Solms-laubachia 
王家坚, 彭智邦, 孙航, 聂泽龙, 孟盈. 青藏高原与横断山被子植物区系演化的细胞地理学特征. 生物多样 性, 2017, 25 (2): 218-225.

http://www.biodiversity-science.net/CN/10.17520/biods.2016281

(Brassicaceae) and two related genera. Botanical Journal of the Linnean Society, 145, 77-86.

Yue JP, Sun H, Al-shehbaz I, Gu ZJ (2003) Cytological studies of five Chinese species of Solms-laubachia (Brassicaceae). Harvard Papers in Botany, 7, 467-473.

Yue XK, Yue JP, Yang LE, Li ZM, Sun H (2011) Systematics of the genus Salweenia (Leguminosae) from southwest China with discovery of a second species. Taxon, 60, 1366-1374.

Yu WB, Huang PH, Li DZ, Wan H (2010) A new species of Pedicularis (Orobanchaceae) from the Hengduan Mountains, southwestern China. Novon, 20, 512-518.

Yu H, Huang RF, Dang CL (1996) A study on the Polymorphism of morphological character of Nomocharis mairei. Acta Botanica Yunnanica, Suppl. VIII, 48-58. (in Chinese with English abstract) [虞泓, 黄瑞复, 党承 林 (1996) 宽瓣豹子花形态特征的多态性研究. 云南植物研究, 增刊VIII, 48-58.]

Yu H, Huang RF, Dang CL (1996) A study on number variation of chromosome in Nomocharis forrestii population. Acta Botanica Yunnanica, Suppl. VIII, 23-34. (in Chinese with English abstract) [虞泓，黄瑞复， 党承林 (1996) 滇蜀豹子花居群染色体数目变异的研究. 云南植物研究, 增刊VIII, 23-34.]

Yu H, Huang RF, Wei RC (1996) Study on karyotypical diversity in Lilium davidii. Acta Botanica Yunnanica, 18(S8), 1-3. (in Chinese with English abstract) [虞泓, 黄瑞复, 魏蓉城 (1996) 川百合种内核型多样性研 究. 云南植物研究, 18(S8), 1-3.]

Zhang GL, Gong X (2002) The karyotype analysis of Anemoclema glaucifolium and Heteroplexis microcephala both endemic to China. Acta Botanica Yunnanica, 24, 765-768. (in Chinese with English abstract) [张国莉, 龚洵 (2002) 中国特有罂粟莲花和小花异裂菊的核型分析. 云南植物研究, 24, 765-768.]

Zhang JW, Nie ZL, Sun H (2009) Cytological study on the genus Syncalathium (Asteraceae, Lactuceae), an endemic taxon to alpine scree of the Sino-Himalayas. Journal of Systematics and Evolution, 47, 226-230.

Zhang JW, Sun H, Nie ZL (2007) Karyological studies on the Sino-Himalayan endemic Soroseris and two related genera of tribe Lactuceae (Asteraceae). Botanical Journal of the Linnean Society, 154, 79-87.

Zhang XQ, Chi Y, Yang JL, Yang Y (1998) Cytogenetic analyses in Kengyilia laxiflora (Poaceae, Triticeae). Plant Systematics and Evolution, 212, 79-86.

Zhang YF, Zhang CY, Zhang T, Guan HL, Yan SQ (2010) A cyto-evolutional study of Campanumoea Blume (Campanulaceae) and a possible pathway for secondary karyotype formation. Plant Systematics and Evolution, 285, 245-257.

Zhang ZY, Sun H, Gu ZJ (2002) Karyomorphological study of the Spiraea japonica complex (Rosaceae). Brittonia, 54, 168-174.

Zhang ZY (1982) Chromosome observations of three ranunculaceous genera in relation to their systematic positions. Journal of the Chinese Academy of Sciences, 20, 402-409. (in Chinese with English abstract) [张 芝玉 (1982) 星果草属、独叶草属、鸡爪草属的染色体观察和系统位置的探讨. 中国科学院大学学报, 20, 402-409.]

Zhou YH (1994) Study on karyotypes of 5 species of Kengyilia. Guihaia, 14, 163-169. (in Chinese with English abstract) [周永红 (1994) 仲彬草属 5 种植物的核型研究. 广西植物, 14, 163-169.]

Zhou J, Pu FD, Peng HJ, Pan YZ, Gong X (2008) Karyological studies of ten Ligusticum species (Apiaceae) from the Hengduan Mountains Region of China. Caryologia, 61, 333-341.

Zhou LH, Wei ZX, Wu ZY (2000) Pollen morphology and systematic position of the Chinese endemic genus Dichotomanthes (Rosaceae). Acta Botanica Yunnanica, 22, 143-147. (in Chinese with English abstract) [周 丽华, 韦仲新, 吴征镒 (2000) 中国特有属牛筋条属的花粉形态与其系统位置. 云南植物研究, 22, 143-147.]

Zhou YH, Sun GL, Yang JL (1993) Study on karyotypes of five species of Roegneria. Guihaia, 13, 149-154. (in Chinese with English abstract) [周永红, 孙根楼, 杨俊良 (1993) 我观草属 5 种植物的核型研究. 广西植 
王家坚, 彭智邦, 孙航, 聂泽龙, 孟盈. 青藏高原与横断山被子植物区系演化的细胞地理学特征. 生物多样 性, 2017, 25 (2): 218-225.

http://www.biodiversity-science.net/CN/10.17520/biods.2016281

物, 13, 149-154.]

Zhou QX, Sun H (2000) Cytological studies on Salweenia wardii. Plant Diversity, 22, 368-370. (in Chinese with English abstract) [周其兴, 孙航 (2000) 冬麻豆的细胞学研究. 植物分类与资源学报, 22, 368-370.]

Zhu HF, Zhang CQ, Gu ZJ, Gong X (2001) A karyomorphological study on nine species of Primula (Primulaceae). Plant Diversity, 23, 466-472. (in Chinese with English abstract) [朱慧芬, 张长芹, 顾志建, 龚洵 (2001) 九种报春花属植物的核形态学研究. 植物分类与资源学报, 23, 466-472.] 